Hiltraud Casper-Hehne/ Irmy Schweiger (Hg.)

\title{
Vom Verstehen zur Verständigung
}

\author{
Dokumentation der \\ öffentlichen Vorlesungsreihe \\ zum Europäischen Jahr des \\ Interkulturellen Dialogs 2008
}



Hiltraud Casper-Hehne und Irmy Schweiger (Hg.) Vom Verstehen zur Verständigung

This work is licensed under the Creative Commons License 2.0 "by-nd", allowing you to download, distribute and print the document in a few copies for private or educational use, given that the document stays unchanged and the creator is mentioned. You are not allowed to sell copies of the free version. 
erschienen im Universitätsverlag Göttingen 2009 
Hiltraud Casper-Hehne und Irmy Schweiger (Hg.)

Vom Verstehen zur Verständigung

Dokumentation der öffentlichen Vorlesungsreihe zum Europäischen Jahr des Interkulturellen Dialogs 2008

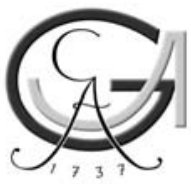

Universitätsverlag Göttingen 2009 


\section{Bibliographische Information der Deutschen Nationalbibliothek}

Die Deutsche Nationalbibliothek verzeichnet diese Publikation in der Deutschen Nationalbibliographie; detaillierte bibliographische Daten sind im Internet über $<$ http://dnb.ddb.de $>$ abrufbar.

Gefördert durch den

Universitätsbund Göttingen e.V. und

die Sparkasse Göttingen

Anschrift der HerausgeberiQQQ

Abteilung Interkulturelle Germanistik

Georg-August-Universität Göttingen

Käte-Hamburger-Weg 6

37073 Göttingen

Dieses Buch ist auch als freie Onlineversion über die Homepage des Verlags sowie über den OPAC der Niedersächsischen Staats- und Universitätsbibliothek

(http://www.sub.uni-goettingen.de) erreichbar und darf gelesen, heruntergeladen sowie als Privatkopie ausgedruckt werden. Es gelten die Lizenzbestimmungen der

Onlineversion. Es ist nicht gestattet, Kopien oder gedruckte Fassungen der freien

Onlineversion zu veräußern.

Satz und Layout: Wiebke Schuldt

Umschlaggestaltung: Jutta Pabst

Titelabbildung: Rothe Grafik in Zusammenarbeit mit Presse, Kommunikation \&

Marketing der Universität Göttingen

(C) 2009 Universitätsverlag Göttingen

http://univerlag.uni-goettingen.de

ISBN: 978-3-941875-07-4 


\section{Inhaltsverzeichnis}

Vom Verstehen zur Verständigung - eine interdisziplinäre

Vorlesungsreihe zum Europäischen Jahr des Interkulturellen Dialogs

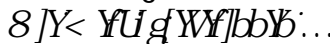

Vom Verstehen zur Verständigung. Öffentliche Vorlesungsreihe zum Europäischen Jahr des Interkulturellen Dialogs. Einleitende

Bemerkungen

Jochen Richter......

Interkultureller D ialog - Konzepte und Visionen internationaler Bildungs- und Kulturarbeit

Jutta L imbach.

Rechtsstaatsdialog mit der VR China - Fortschritt oder Feigenblatt?

Christiane W endehorst.

Toward Post-Multiculturalism? Changing Communities, Conditions and Contexts of Diversity

Steven V ertovec.

Fremdbilder - Feindbilder? Ein Islambild in der deutschen Presse. Zur

Kopftuch-D ebatte im SPIEGEL 1998-2008

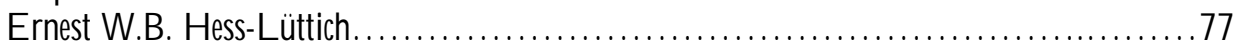

Die Wahrnehmung des religiös Fremden: Exotik, Empathie und allergische Abwehr

A ndreas G rünschloß.

Interkulturelle Interaktion: Heterogenität als Chance?

H iltraud Casper-H ehne..

Philosophische Fremdgänge(r): Deutsch-chinesische Begegnungen im 17. und 18. Jahrhundert

A drian $\mathrm{H}$ sia.....

Europa wird neu vermessen oder: Eine Art Atlantis

Karl Schlögel... 
Interkulturelle Bildung - mehr als nur , andere Kulturen verstehen lernen'. Verstehen und Verständigung in interkulturell pädagogischer Perspektive

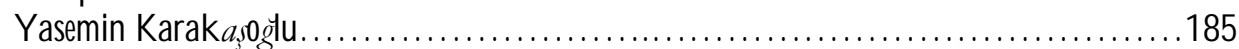

Die Welt in D eutschland

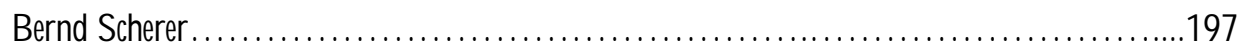

Autorinnen und Autoren..................................................... 207 


\section{Vom Verstehen zur Verständigung - eine interdisziplinäre Vorlesungsreihe zum Europäischen Jahr des Interkulturellen Dialogs}

Im Hinblick auf weltweite Globalisierungsprozesse und eine veränderte gesellschaftliche, religiöse, und weltwirtschaftliche Komplexität haben die Begriffe „Interkulturalität" und "Dialog“ in den vergangenen Jahren vehement an Bedeutung gewonnen und dies nicht nur in der politischen Praxis, sondern auch in zahlreichen Wissenschaftsdisziplinen. Dabei ist nicht zu übersehen, dass „Interkulturalität“ theoretisch bislang nur vage fundiert und verankert ist, jedoch als Bezugspunkt für einen sich neu entwickelnden Verstehens- und Interaktionszusammenhang immer wieder in Erscheinung tritt. G enau in diese „Leerstelle“ sucht eine Vorlesungsreihe zu treten, die es sich zum Ziel macht, aus verschiedenen Blickwinkeln sich mit einem „Interkulturellen Dialog“ auseinanderzusetzen und diesen kritisch zu beleuchten: aus der Perspektive unterschiedlicher, in vielerlei Hinsicht am akademischen Diskurs aktiv beteiligter Fächer, aber auch im Hinblick auf unterschiedliche Regionen, Länder und Kulturen.

Im Jahr 2008 hat die Europäische Union das „Jahr des Interkulturellen Dialogs" ausgerufen mit dem Ziel, auf die ständig wachsende kulturelle Vielfalt in unserer Gesellschaft aufmerksam zu machen und den interkulturellen Dialog zwischen EU-Mitgliedsstaaten, zwischen der EU und außereuropäischen Staaten sowie innerhalb der EU-Staaten zu befördern. Für die einzelnen Gesellschaften geht es darum, die interkulturelle Kompetenz ihrer Bürgerinnen und Bürger zu stärken und ein auf gegenseitiger Toleranz und Anerkennung basierendes, friedliches Miteinander im Altags- und Berufsleben zu fördern. D ass dies ein langer und mitunter schwieriger Weg ist, darin sind sich alle einig.

Interkulturalität ist das explizite Zentrum von Forschung und Lehre der G öttinger Interkulturellen G ermanistik. Über die inhaltliche Fokussierung hinaus, ver- 
Die erausgeberinnen

folgt die Interkulturelle Germanistik auch das Ziel, Interkulturalität als Struktur herzustellen und ihre Arbeits- und Forschungsprojekte grundsätzlich interkulturell auszurichten. Von der EU-Initiative angesprochen, richtete sie am Wissenschaftsstandort Göttingen die Vorlesungsreihe "Vom Verstehen zur Verständigung" aus, die sich mit wissenschaftlichen und politischen Konzepten und Visionen des interkulturellen Dialogs auseinandergesetzt und aktuelle und differenzierte Diskussionen in den Wissenschafts- und Bildungsraum Südniedersachsen hineingetragen hat.

Dabei verfuhr die Vorlesungsreihe in Abgrenzung zu Konzepten von Multikulturalität und Transkulturalität und in Anknüpfung an D iskussionen über „Kulturen im Kontakt" und „Kulturen im Konflikt" sowie in Auseinandersetzung mit den vielfältigen Dialogbegriffen, vom konsensuellen bis zum konfliktiven. Die nunmehr hier versammelten Aufsätze verstehen sich als Beiträge zu diesem multiwie auch interdisziplinären Interkulturalitäts-D iskurs. In ihrer Zusammenschau plädieren sie für ein vernetztes Verstehen, das Grenzen zwischen Disziplinen, Kulturen, Religionen sowie Nationen hinter sich lässt. Nicht die Aneinanderreihung fachdisziplinärer Einschätzungen steht im Vordergrund, vielmehr sollen unterschiedliche Positionen, Konzepte und Perspektiven dokumentiert werden, die sich dialogisch und im D ienste wechselseitiger Erhellung verstehen.

Es liegt gewissermaßen in der Logik der Sache, dass die Vorlesungsreihe von einem Vertreter der EU, dem stellvertretenden Kabinettschef und Vertreter der Kommission für Mehrsprachigkeit, Jochen Richter, eröffnet wurde. Dies sahen die Veranstalterinnen nicht nur als Beleg dafür, dass die EU-Kommission in Brüssel nachhaltiges Interesse an den wissenschaftlichen Aktivitäten der Universität Göttingen zeigt, Jochen Richter macht in seiner Eröffnung auch deutlich, welche Intentionen die EU mit diesem Europäischen Jahr des Interkulturellen D ialogs verfolgt und auf welche Problemstellungen und Herausforderungen diese EUInitiative reagiert. In seinem Beitrag fokussiert Richter die Rolle der Sprache, ohne die jeglicher interkultureller D ialog schlicht sprachlos bliebe.

Mit der ehemaligen Präsidentin des Bundesverfassungsgerichtes und inzwischen auch ehemaligen Präsidentin des Goethe-Instituts, Jutta Limbach, konnten die Veranstalterinnen eine Persönlichkeit gewinnen, die im Feld des interkulturellen Dialogs sowohl theoretisch als auch praktisch beheimatet ist. Jutta Limbach hat sich während ihrer Zeit am Goethe-Institut besonders stark für die deutsche Sprache weltweit und als Europasprache eingesetzt. So hat sie den deutschen Sprachrat gegründet und ein Buch zur Zukunft der deutschen Sprache geschrieben. Als eine Aufgabe des Goethe-Instituts hat sie bestimmt, dass das Goethe-Institut nicht nur in der „Fremde“, sondern auch im eigenen Lande aufklärend wirken soll, um die Erfahrungen aus dem wechselseitigen Kulturaustausch zurückzuvermitteln. Jutta Limbach war Mitglied der von der EU Kommission eingerichteten Intellektuellengruppe zur Erarbeitung von Vorschlägen für den interkulturellen Dialog. In ihrem Eröffnungsbeitrag setzt sie daher die Überlegungen 
Jochen Richters zur Mehrsprachigkeit fort und entfaltet Sprache als Schlüssel nicht nur des gegenseitigen Verstehens, sondern auch als Schlüssel für das Verständnis der Welt. Sie argumentiert im Humboldt'schen Sinne, dass Sprache Ausdruck der Verschiedenheit des Denkens und damit auch eine Ansicht von der Welt sei. Mehrsprachigkeit gilt ihr daher als Voraussetzung dafür, Menschen zu Weltbürgern zu machen und Europa zu konsolidieren.

Der grundlegenden Frage nach den Chancen und Möglichkeiten eines gelingenden, interkulturellen Dialogs stellt sich auch die Rechtswissenschaftlerin und ehemalige G öttinger Direktorin des D eutsch-chinesischen Instituts für Rechtswissenschaft, Christiane Wendehorst. In ihrem Beitrag befasst sie sich mit dem „Reizthema" Rechtsstaatsdialog mit der VR China und stellt die Frage, inwiefern es hier Fortschritte zu verzeichnen gilt. Eine Fragestellung, die sich spätestens im Vorfeld der Olympischen Spiele 2008 in Beijing nicht zuletzt aufgrund zweifelhafter Medienberichte und einer fragwürdigen Fremd- und Selbstwahrnehmung sowohl auf der deutschen, als auch auf der chinesischen Seite geradezu aufdrängt: Chinabashing und moralische Überheblichkeit hier, Verteufelung westlicher Medien und nationalistische Selbstfeier dort. Wendehorst zeigt, dass es nicht darum gehen kann, sensationelle „Fortschritte“ oftmals naiver Erwartungen einzufordern. Vielmehr bilanziert sie, dass durch den regelmäßig stattfindenden Rechtsstaatsdialog eine Versachlichung des Menschenrechtsdiskurses erreicht wurde, was der Tatsache zu verdanken sei, dass es an unterschiedlichen Stellen gelungen sei, eine abstrakte Problematik auf konkrete Fragestellungen und Maßnahmen hin zu lenken.

Steven Vertovec, Direktor des Max-Planck Institut für multireligiöse und multiethnische $\mathrm{G}$ esellschaften stellt sich der Frage, inwiefern die Diskussion um Konzepte einer multikulturellen Gesellschaft längst das Stadium eines „Post-Multikulturalismus" erreicht habe. Zunehmend werde man in Politik und Wissenschaft gewahr, dass die D ifferenzorientierung der Ideologie des Multikulturalismus nicht Gleichheit schaffe, sondern eher einen „uneven pluralism" fördere, also soziale Unterschiede verschärfe. Die Betonung der Differenz verstärke Zuschreibungsprozesse, welche Minderheiten von wirklich mächtigen Positionen fernhielten, gerade indem sie in ihrer kulturellen Eigenart bestätigt würden. Das Zelebrieren kultureller Unterschiede würde oftmals die Diskriminierung in struktureller Hinsicht kompensieren.

Der Beitrag des Linguisten und Medienwissenschaftlers Ernest W.B. HessLüttich trägt der Tatsache Rechnung, dass seit 9/11 die Berichterstattung über den Islam einerseits in ungekanntem Ausmaß intensiviert und differenziert wurde, anderseits die Terroranschläge in den Medien noch immer systematisch mit dem Islam verknüpft werden. Medial verbreitete Analysen und Kommentare suggerieren einen Zusammenhang von Islam und G ewalt, weshalb vor allem Symbole des Islam markierende und stereotypisierende Kraft gewinnen. Am Beispiel der sog. „Kopftuch-Debatte“ zeigt Hess-Lüttich, welche Macht Bilder haben und wie Bilder Realitäten erzeugen. Sein exemplarischer Beitrag ist ein Hinweis auf die Herausforderungen, denen sich eine interkulturelle Medienwissenschaft stellen 
Die erausgeberinnen

muss, bzw. berührt die Frage, wie dialogfähig eine G esellschaft im medialen Zeitalter ist und sein kann.

D er Religionswissenschaftler Andreas G rünschloss befasst sich auf der G rundlage systematischer Raster mit interreligiösen Wahrnehmungs- und Austauschprozessen mit dem religiös „Fremden“. Dabei wird bei der Aneignung, Ablehnung oder Inkorporation ,fremder' religiöser Lebensäußerungen eine Variationsbreite erkennbar, die systsematisierend weitaus differenzierter ist als das gängige D reierSchema von Exklusivismus, Inklusivismus und Pluralismus. Grünschloss macht deutlich, dass religiöse Sinnsysteme die Auseinandersetzung mit dem religiös Fremden durchaus widersprüchlich und je nach Zeit, Kontext und Frontstellung verschieden steuern können.

Hiltraud Casper-Hehne zeichnet als Sprachwissenschaftlerin die Rolle von Missverständnissen in der interkulturellen Kommunikationsforschung nach. D abei wendet sie sich gegen eine Kulturalisierung von Interaktionsverhalten, die davon ausgehe, dass interkulturelle Interaktion lediglich eine Reproduktion sprachlicher Konventionen sei, welche die Interaktanten in ihrer Eigenkultur erworben hätten, und plädiert für eine Betrachtung von Interaktion als Aushandlungsprozess, in dem multifaktorielle Einflüsse zusammenwirken und neue Interaktionsformen hervorbringen.

Trans- und interkulturellen Transferprozessen in der deutsch-chinesischen Philosophiegeschichte des 17. und 18. Jahrhunderts widmet sich der Germanist Adrian Hsia. Dabei wird ersichtlich, dass die Rezeption und Aneignung des Fremden immer in Abhängigkeit des bereits vorhandenen Wissens erfolgt. So vermittelten die Jesuiten ein Chinabild nach ihren Prämissen, das sich nicht nur von dem zeitgenössischer Bettelorden unterschied, sondern auch kaum mit einer chinesischen Wirklichkeit übereinstimmte. Ähnlich verhält es sich nach Hsia mit späteren Rezipienten wie Leibniz, Wolff oder Herder.

D er O steuropa-Historiker Karl Schlögel, dessen Werke seit jeher wegweisende Impulse zur G eschichte und G egenwart O steuropas sowie über die „Neuvermessung" Europas liefern, verweist in seinem Beitrag darauf, dass plurale Identitäten und Loyalitäten keineswegs eine Errungenschaft der Postmoderne mit ihren Identitäts-, Alteritäts- und Hybriditätsdiskursen sind. Vielmehr würden derzeit 1914 abgebrochene Arbeiten wieder aufgenommen. D abei gelte es, die Erinnerung und Vergegenwärtigung historischer Spuren ehemaliger kultureller Zentren und ihrer Zugehörigkeit zu Europas wieder- und neu zu entdecken. Derzeit, so Schlögel, entstehe eine neue Europakarte und das zweigeteilte Europa erhalte neue Konturen, das sich nicht mehr an Ost-West-Einteilungen orientiere, sondern sich aus unterschiedlichen $\mathrm{G}$ eschichts- und Kulturräumen zusammensetze.

Welche Implikationen interkulturelle Bildung, nicht nur theoretisch, sondern auch in der praktischen Anwendung haben muss, zeigt die Erziehungswissenschaftlerin Yasemin Karakaşoğlu auf. Sie ist nicht nur Lehrstuhlinhaberin des in D eutschland einzigartigen Lehrstuhls für Interkulturelle Bildung der Universität Bremen, sondern hat u.a. als Gutachterin beim Prozess vor dem Bundesverfas- 
sungsgericht im sog. Kopftuchstreit des Landes Baden-Württemberg eine entscheidende Rolle gespielt. Karakaşoğlu verweist darauf, dass das nach wie vor dominierende Paradigma - die Aneignung von Kulturkenntnissen reiche aus, um Fremdheit zu überwinden - eine unzulässige Verkürzung dessen sei, was interkulturelle Bildung ausmache.

Hatte die Vorlesungsreihe mit Jutta Limbachs Perspektive von D eutschland in der Welt am Beispiel des G oethe-Instituts begonnen, nimmt Bernd Scherer zum Schluss der Reihe einen Blickwechsel vor und thematisiert die Welt in Deutschland. Scherer zeigt am Beispiel des Ausstellungsprojektes „Re-imagining Asia“ im $\mathrm{H}$ aus der Kulturen der W elt wie hier Orte erfahrbar werden, an denen östliche und westliche Darstellungsverfahren und Positionen zur Geltung kommen und in Wettstreit treten. Die Wechselbeziehungen Europas zur Welt, die es neu zu betrachten gilt, veranschaulicht Scherer an dem Projekt "In der Wüste der Moderne“. Hier wird im Kontext der Architekturmoderne deutlich, dass das kolonisierte Afrika ein zentrales Labor der westlichen Moderne war und dass die dort entwickelten urbanen Konzepte Modellcharakter für das Bauen der 50er und 60er Jahre hatten.

Die Vorlesungsreihe verstand sich als Impulsgeberin nicht nur für den akademischen Diskurs, sondern auch für die öffentliche D ebatte. In den Beiträgen erkennbar ist eine Prozesshaftigkeit, die zunächst ausgehend von einer vorherrschenden Hermeneutik des Fremden auf die Überwindung von Fremdheit zielt und sich hin zur Anerkennung der D ifferenz und Vielfalt von Kulturen bewegt.

Die Herausgeberinnen danken den Beiträgerinnen und Beiträgem für ihre Bereitschaft, ihre Thesen und Überlegungen im Rahmen der Vorlesungsreihe einem größeren Publikum vor- und zur D iskussion zu stellen und als Aufsätze im vorliegenden Band zu publizieren. Ein großer Dank auch an den Universitätsbund e.V. der Universität Göttingen sowie an die Sparkasse Göttingen für ihre finanzielle Unterstützung. 



\title{
Vom Verstehen zur Verständigung. Öffentliche Vorlesungsreihe zum E uropäischen Jahr des Interkulturellen D ialogs: Einleitende Bemerkungen
}

\author{
Jochen Richter
}

Der interkulturelle Dialog ruht in der Europäischen Kommission auf drei Schultern. D er Präsident, Herr Barroso, ist für religiöse Fragen zuständig, Herr Kommissar Figel hinsichtlich der kulturellen Aspekte und Kommissar Orban für die Sprache. Ihre Reihe „Vom Verstehen zur Verständigung“ verfolgt den Zweck, möglichst viele Aspekte des interkulturellen Dialogs anzusprechen. Ich möchte mich im Folgenden auf einige G edanken hinsichtlich der Rolle der Sprache konzentrieren. Wir sind uns sicher alle einig, dass interkultureller Dialog ohne Sprache gar nicht funktionieren könnte, ja er bliebe sozusagen sprachlos.

Verstehen hat viel mit Begreifen und Erfassen zu tun, und dazu braucht es Sprachverständnis. Verständigung wiederum erfordert Offenheit und Toleranz eben auch gegenüber Sprache, K ultur und Identität.

Gestatten Sie mir einige Anmerkungen persönlicher Art bezüglich unserer Wahrnehmung des interkulturellen D ialogs. Wie sehen wir unsere Zukunft in einer globalisierten Welt? Reduziert sich nicht zu häufig interkultureller Dialog auf den schon vor langer Zeit vom Club of Rome beschworenen clash of avilisation? Wie nehmen wir überhaupt Kultur oder andere G esellschaften wahr? 
Jochen Richter

Reisen oder Urlaube ermöglichen nur schemenhafte Eindrücke. Und Fernsehen und Internet bieten reduzierte und oft auf bestimmte Aspekte ausgerichtete Einsichten.

G oethes Reise nach Italien dauerte seinerzeit drei Jahre und danach bemerkte er vermutlich völlig zu recht, er habe die Italiener wohl immer noch nicht ganz verstanden. So meine ich, wir bewegen uns zu häufig zwischen Realität und Virtualität, und es mangelt oft an der kritischen Reflektion.

Zurück zur Frage nach der Bedeutung der Sprache. Die Besuche, die der Kommissar mittlerweile in zwanzig Mitgliedstaaten und vielen Regionen abgestattet hat, erfahren eine gesteigerte Aufmerksamkeit. D ie EU und ihre Institutionen sind multilingual. Ist es Europa und sind es seine Bürger auch? Vielsprachig sind wir sicher.

Zur Erinnerung, es war das Insistieren der römisch-katholischen Kirche auf Latein als die Sprache, die Europa multilingual machte, und wodurch Übersetzungen Teil der Schulbildung wurden. Interkultureller D ialog begann nach Auffassung einiger Wissenschaftler bereits im 6. Jahrhundert nach Christi mit der Schließung der Platonischen Akademie 529 und der Verbreitung der Lehren Platons und anderer im Orient.

Aber noch einmal, ist Europa und sind seine Bürger mehrsprachig? Ist trotz des Beschlusses von 2002 in Barcelona, Muttersprache plus zwei Fremdsprachen, die Mehrsprachigkeit Realität des „normalen“ Bürgers?

Sprachenlernen, auch und gerade das Fremdsprachenerlernen, funktioniert doch noch genauso wie vor vierzig Jahren, als ich dies mit Homer und Shakespeare genießen durfte. Wir sind der Überzeugung, dass die Vermittlung interkultureller Fähigkeiten viel stärker Teil des Sprachunterrichts werden muss. Wir haben darüber hinaus ein Problem bei der Motivation und viele Lehrkräfte bräuchten mehr und moderne Unterstützung. Juvenes translatores war dafür ein guter Beleg. Wir hatten Jugendliche aus ganz Europa zu einem Übersetzungswettbewerb eingeladen. Die Besten aus jedem Land wurden als Gewinner nach Brüssel eingeladen. Die doch sehr anspruchsvollen Texte waren von unseren professionellen Übersetzern geprüft worden. Und trotz einer gewissen Konzentration der Übersetzungen auf Englisch und Französisch waren die Jugendlichen beim Treffen in Brüssel kaum in der Lage, sich miteinander zu unterhalten und auszutauschen. Obgleich sie also über gute Sprachkenntnisse verfügten, mangelte es an Erfahrung im Umgang mit der gesprochenen Sprache. Daher muss man sich vielleicht noch einmal mit dem zu erreichenden Sprachniveau auseinandersetzen. Passivkenntnisse können dabei von größerer Bedeutung sein als man bis jetzt angenommen hat. D enn der Barcelona-Beschluss war ja nicht für Eliten, sondern für alle Bürger gedacht.

Mit der eingangs erwähnten G lobalisierung rücken auch Sprachkenntnisse anderer Kulturräume, wie China, Indien oder Russland mehr und mehr ins Blickfeld. In diesem Zusammenhang begreift auch die Geschäftswelt, wie eine Studie deutlich belegt, dass alleinige Englischkenntnisse heute längst nicht mehr ausreichen. 
Oder wie der Kommissar für Mehrsprachigkeit, Leonard Orban, immer wieder betont: Die Sprache des Konsumenten ist eben seine Muttersprache.

$D$ aneben ist die Frage der Integration von Migranten in unsere G esellschaften immer wichtiger geworden. Ich denke, die Mehrzahl befürwortet heute die Notwendigkeit, die Sprache des Gastlandes lernen zu müssen, um sich integrieren zu können. Aber sollten wir nicht auch davon profitieren, dass Migranten ihre kulturellen und sprachlichen Kenntnisse mitbringen? Vor diesem Hintergrund hat die von Kommissar O rban eingesetzte G ruppe von Intellektuellen unter dem Vorsitz von Amin Malouf, einem französisch-libanesischen Schriftsteller, das Konzept der „personal adopted language“ entwickelt. Eine Sprache meiner Wahl, die mich über die linguistischen Aspekte hinaus auch hinsichtlich Kultur, Literatur und G eschichte interessiert. Ich empfehle Ihnen allen die Lektüre des Berichts.

D ass profunde Kenntnisse der Muttersprache unabdingbar sind, steht ebenso außer Zweifel wie der Erfolg des Spracherlernens in jungen Jahren. Aber die eigentliche Herausforderung liegt in der Einbindung derer, die bereits der Schul- und Weiterbildung entwachsen sind. Und daneben in der Einbeziehung der Eltern, vor allem bei Migrantenkindern. Die unterschiedlichen Integrationsmodelle, sei es in Frankreich, Deutschland, Großbritannien oder den Niederlanden, kämpfen heute letztlich mit sehr ähnlichen Problemen.

Aber zurück zur Ausgangsfrage Sprache versus interkultureller D ialog. Wie gesagt, ohne Sprache gibt es keine Kommunikation. Sprache schafft vor allem Identität, sie ist Basis unserer jeweiligen Kultur. Ein Eintauchen in andere Kulturen, ohne deren Sprache zu kennen und zu beherrschen, geht wohl nicht. Und trotzdem brauchen wir häufig eine gemeinsame Sprachbasis. Also doch eine lingua franca, z.B. Englisch? Hier ist Vorsicht angebracht, denn sagen wir nicht häufig in Englisch, was wir sagen können und nicht, was wir sagen wollen? Dies wäre unweigerlich der Anfang vom Ende eines wirklichen interkulturellen Dialogs. Im Übrigen bezeichnen Sprachwissenschaftler inzwischen die Form des Englisch, welches wir international zur Verständigung gebrauchen, als Globish, einen auf das Nötigste beschränkten Wortschatz.

Um abzuschließen, Sprache und interkultureller Dialog bedingen einander. Unser Ziel ist, von der Vielsprachigkeit Europas hin zu einer gelebten Mehrsprachigkeit zu kommen, ganz nach dem Motto: Einheit in Vielfalt. 



\section{Interkultureller Dialog - Konzepte und Visionen internationaler Bildungs- und Kulturarbeit}

Jutta L imbach

\section{Antriebskräfte des interkulturellen Dialogs}

Zwei Phänomene sind es, die die westliche Welt in Atem halten und ihre Menschen Zuflucht im interkulturellen Dialog suchen lassen: D er unaufhaltsame Prozess der Globalisierung und der internationale Terrorismus religiöser Fanatiker.

Erinnern wir uns zunächst an den 11. September 2001. Die geographische und religiöse Herkunft der Terroristen löste prompt die Frage aus, ob sich „der Westen" in einem „Kulturkampf" gegen „den Islam“ befindet. Hat Samuel Huntington, so fragten wir uns damals, mit seinem Kampf der Kulturen doch Recht? Dieser hatte sich allerdings schon vor jenem Terroranschlag dagegen verwahrt, dass seine These als Prophezeiung gelesen wird (Huntington 1996: 12). Ob Samuel Huntington die Konfliktlinien und Konfliktursachen richtig beschrieben hat, sei hier dahingestellt. Richtig ist, dass die Konflikte im Grenzbereich von Politik und Kultur die auswärtige Kulturpolitik zu einem interkulturellen Dialog herausfordern. D enn wir haben seit dem 11. September im Zeitraffertempo gelernt, dass man den Terrorismus weder militärisch besiegen noch durch Einschränkung der Menschenrechte erfolgreich bekämpfen kann. Die Zukunft des Friedens hängt vielmehr vor allem davon ab, dass die Menschen der verschiedenen Kulturen einander verstehen und miteinander zusammenwirken. Weder die Vorherrschaft einer Kultur über die anderen noch das Einebnen der kulturellen Vielfalt kann eine Erfolg verheißende Strategie für eine menschenwürdige Weltgesellschaft sein. 
Die entgrenzte Wirtschaft wird als Bedrohung unserer geistigen und kulturellen Welt empfunden. D ie Weltläufigkeit des Kapitals und die Landflucht multinational organisierter Unternehmen, lösen G efühle der O hnmacht aus. Gerade in jüngster Zeit gedeiht der Z weifel, ob die internationalen Finanzmärkte überhaupt noch von irgendjemand kontrolliert werden können. Gern wird von einer Amerikanisierung gesprochen, die auch unser gesellschaftliches und kulturelles Leben durchdringe. $\mathrm{Ob}$ man den Ausgangspunkt kultureller Vorherrschaft so eindeutig verorten kann, lasse ich dahingestellt. G emeint ist das Unbehagen an dem mit der Vernetzung der Wirtschaft und des Verkehrs einhergehenden Trend zu einer Weltsprache, zu einem ökonomischen, politischen und sozialen System. Die Sorge, dass jene homogenisierenden Kräfte sich allmählich zerstörerisch auch auf unsere Kultur, Sprache, Sitten, Traditionen und Identitäten auswirken könnten, liegt auf der Hand (Malouf 2000: 94-97).

In Anbetracht der Tatsache, dass die Politik immer häufiger vor Aufgaben steht, die die nationalen Grenzen überschreiten, setzen wir unsere Hoffnung auf die Europäische Union. D iese ist letztlich aus der Friedenssehnsucht der Völker nach dem Zweiten Weltkrieg hervorgegangen. Sie ist heute eine Strategie der europäischen Staaten, im Prozess der Globalisierung das Primat der Politik zu behaupten. Nur ist das europäische Projekt seit dem Scheitern des Verfassungsvertrags wieder einmal flügellahm geworden. D ie ursprüngliche Friedensvision ist verblasst. Über das geschäftige Knüpfen eines - für die Bürger und Bürgerinnen undurchschaubaren - Netzes von Richtlinien, Produktnormen und Richtersprüchen scheint nicht nur das Vertrauen der Bürger, sondern auch die europäische Idee abhanden gekommen zu sein (Brodersen/ D ammann 2003: 4). D iese will nach dem Fall des Eisernen Vorhangs und dem Beitritt der mittel-, ost- und südeuropäischen Staaten neu fundiert und erzählt werden.

Seit dem Nein der Franzosen und Niederländer zum Verfassungsvertrag wächst die Einsicht, dass die Europäische Union ohne eine das „Markteuropa“ transzendierende Idee, ohne ein soziales, geistiges und kulturelles Fundament nicht mehr auskommen wird. So treffend Brodersen und Dammann (Brodersen/ Dammann 2003: 6). Die Tatsache, dass die Union das Jahr 2008 dem interkulturellen Dialog gewidmet hat, zeigt, dass die Union dabei ist, im geistig-kulturellen Bereich ein neues Selbstverständnis zu entwickeln. Die Sorge, dass auch von der Union ein D ruck auf eine internationale Verkehrssprache, auf einen „European way of life" und auf ein Einebnen kultureller Unterschiede ausgehen könnte, ist unbegründet. Nehmen wir die Union beim Wort, so hat sie den Reichtum ihrer kulturellen und sprachlichen Vielfalt zu wahren und für den Schutz und die Entwicklung des kulturellen Erbes Europas zu sorgen. So ausdrücklich der im Ratifikationsverfahren befindliche Reformvertrag. Jetzt gilt es, die Europa auszeichnenden kulturellen Unterschiede klug mit Hilfe des interkulturellen D ialogs zu harmonisieren. 


\section{Der interkulturelle Dialog}

\section{Das Prinzip der G egenseitigkeit}

Der interkulturelle Dialog ist ein voraussetzungsvolles Unterfangen. Die ihn leitende Philosophie ist das Prinzip der G egenseitigkeit. Das setzt die Fähigkeit voraus, sich in den jeweils anderen hineinzuversetzen. Was allerdings nur glücken kann, wenn die Partner des G esprächs für die Lebensweisen und Erfahrungshorizonte des jeweils Anderen aufgeschlossen sind. Dabei geht es nicht schlicht um den Abbau von Vorurteilen auf beiden Seiten. Gefordert ist überdies die Bereitschaft, selbstkritisch die eigene Weltsicht, die Muster des eigenen Denkens und Handelns in Frage zu stellen und sich auf einen gegenseitigen Lernprozess einzulassen, der die eigene Perspektive überschreitet (M. Wälde). Aus dieser den interkulturellen Dialog fördernden Haltung folgt weder die moralische noch die politische Anerkennung der Denk- und Handlungsmuster des Anderen. Mit einem Konflikt aggressionsfrei umzugehen, bedeutet nicht den Verzicht, für den eigenen Standpunkt mit Nachdruck einzutreten.

D ie auswärtige Kulturarbeit - wie wir sie im Goethe-Institut verstehen - zielt auf das gegenseitige Verstehen von G esellschaften, um auf diese Weise zum Erhalt des Friedens beizutragen. In den Anfangsjahren der Bundesrepublik ging es darum, den europäischen Nachbarn ein anderes Deutschland näher zu bringen als jenes, das sie während des Zweiten Weltkriegs kennengelernt haben. Das hat eine kritische Auseinandersetzung mit dem Rückfall in die Barbarei nie ausgeschlossen. Im G egenteil, wir mussten uns selbst fragen und auch von unseren Partnern fragen lassen, ob nicht mit unserem Kultur- und Bildungsverständnis von Anfang an ein nationales Überlegenheitsgefühl verbunden war.

Zwar gilt unsere Aufmerksamkeit nach wie vor den unvergänglichen und gegenwärtigen Leistungen deutscher Kunst, Literatur und Musik. D och die Praxis einseitiger Selbstdarstellung ist schon in den siebziger Jahren durch das Prinzip von Austausch und Zusammenarbeit ersetzt worden. Kulturelle Außenpolitik darf keine Einbahnstraße sein, so hat es der damalige Kulturstaatssekretär Ralf Dahrendorf gesagt: Es gehe nicht darum, „andere zu indoktrinieren, sie einseitig vom Wert deutscher Dinge zu überzeugen, sondern Brücken zu bauen, über die der Verkehr in beiden Richtungen fließen kann. Kulturelle Außenpolitik zielt auf Austausch, nicht auf Einfluss" (Peisert 1978: 16).

D as weltweit organisierte Netzwerk der G oethe-Institute schließt notwendig die Bekanntschaft mit der kulturellen Vielfalt auf Erden ein. Ein Mitarbeiter des Goethe-Instituts, der die Partnerschaftlichkeit des Kulturaustauschs ernst nimmt, muss sich mit dem jeweiligen kulturellen Hintergrund seines Wirkungsorts vertraut machen. Der konkrete Kulturaustausch findet denn auch von Ort zu Ort in sehr unterschiedlichen Projekten statt (Knopp 2007: 69). 
Migration - kulturelle Grenzgänger im eigenen Land

D er interkulturelle Dialog, so hatte ich eingangs gesagt, beruht auf dem Prinzip der $\mathrm{G}$ egenseitigkeit. D as gilt unabhängig davon, ob dieser Dialog jenseits oder diesseits der Landesgrenzen geführt wird. Die Vielfalt der Kulturen, die wir seit jeher im Weltmaßstab kennen, erfahren wir seit den fünfziger Jahren des vorigen Jahrhunderts auch innerhalb unserer nationalen $\mathrm{G}$ renzen. D eutschland ist ein Einwanderungsland mit einer kulturell gemischten $G$ esellschaft. Die wachsende Vielfalt der Kulturen führt unvermeidlich zu Spannungen und Konflikten. Wer gleichwohl das friedliche Zusammenleben von Menschen unterschiedlichen Glaubens, anderer Rasse und Herkunft gewährleisten will, sollte nicht eine christlich-abendländische Leitkultur zum Maßstab aller machen.

Unter der Herrschaft des Grundgesetzes, das die Freiheit des Glaubens, des $\mathrm{G}$ ewissens und des weltanschaulichen Bekenntnisses schützt, ist ein Streben nach geistig-geistlicher Vorherrschaft im Sinne einer Leitkultur fehl am Platz. D en Begriff Leitkultur sollten wir übrigens aus dem Verkehr ziehen. Schon wegen seines Beiklangs von nationaler Überheblichkeit steht er einer unvoreingenommenen D ebatte entgegen. Auch die besten Absichten seiner Verwender werden ihn nicht von dem Verdacht befreien, sich abheben und andere Kulturen ausgrenzen zu wollen. Statt Überlegenheit zur Schau zu stellen, sollte vielmehr ein gemeinsamer Verständnishorizont zwischen den verschiedenen Kulturen erarbeitet werden.

„Interkulturalität“, so hat es der heutige Papst im Gespräch mit Habermas über Vernunft und Religion treffend gesagt, scheint „eine unerlässliche Dimension für die Diskussion um die Grundfragen des Menschseins zu bilden, die weder rein binnenchristlich noch rein innerhalb der abendländischen Vernunfttradition ge führt werden kann" (Ratzinger 2005: 53). D ie Einsicht, dass wir in gemeinsame Probleme verstrickt sind, fordert trotz aller kulturellen Unterschiede zur Suche nach gemeinsamen Lösungsmodellen heraus. Dieser interkulturelle Suchprozess und damit unsere Bereitschaft zur Toleranz, kennt verfassungsrechtliche Grenzen. Diese werden durch den Schutz der Würde und Gleichheit aller Menschen wie ihrer körperlichen und geistigen Unversehrtheit abgesteckt. Von diesen Werten können keine Abstriche gemacht werden, auch nicht unter Berufung auf eine wie auch immer geartete oder begründete kulturelle Besonderheit.

\section{D as Eigene im Fremden}

Die Fähigkeit zur Reflektion von Fremdheit gehört zur intellektuellen Grundausstattung eines jeden im Auftrag der auswärtigen Kulturpolitik tätigen Kulturmittlers. D ie G oetheianer lehren die eigene Muttersprache als Fremdsprache. Was das bedeutet, thematisiert die interkulturelle Germanistik (Albrecht 2003). Der D eutschunterricht in der Fremde hat zum einen die Aufgabe, sich in den jeweiligen Erfahrungshorizont des D eutschlerners hineinzuversetzen. Zum anderen erfordert 
der Spracherwerb, dass die Schüler mit der soziokulturellen Erfahrungswirklichkeit der anderen Sprachgemeinschaft vertraut gemacht werden.

In der heutigen offenen Weltgesellschaft ist das Fremdsein eine allgemeine Erfahrung. Im $\mathrm{G}$ efolge der $\mathrm{G}$ obalisierung reisen nicht nur Unternehmer, Kaufleute und Politiker rund um die Welt. Der technologische Fortschritt im Verkehrswesen gestattet jedermann und jeder Frau Länder kennenzulemen, die ihre Vorfahren allenfalls aus Abenteuerromanen kannten. Die Billigfluggesellschaften transportieren Wirtschaftskapitäne und Urlauberinnen ohne Ansehung der Person. Vor allem jene, die aus beruflichen $\mathrm{G}$ ründen reisen, müssen mit Angehörigen anderer kultureller und religiöser Traditionen, politischer Systeme, Mentalitäten und Sprachen interagieren können. Von immer mehr Menschen, so treffend Alois Wierlacher, wird Mehrsprachigkeit „und ein begründetes Wissen von Eigenheit, Andersheit und Fremdheit als Teil ihrer interkulturellen G rundausstattung erwartet" (Wierlacher 2004: 22). Mehr und mehr lassen große Konzerne ihr Personal systematisch in interkultureller Kompetenz fortbilden.

Aber auch in den Schulen wird das Verständnis für das Fremde mehr und mehr zum G egenstand des Unterrichts (Wagner 1997: 254f., Pellens 1997: 256f.). Dieses didaktische Programm folgt der Einsicht, dass sich früh übt, wer als Weltbürger die Herausforderungen der Zukunft meistern will. Das Entdecken von Eigenem im Fremden erleichtert die Aufnahme des Gesprächs und baut Vorurteile ab. Spielerisch kann es mit der Suche nach eingewanderten oder ausgewanderten Wörtern beginnen, die deutlich machen, in welchem Maße schon seit Jahrhunderten die in unterschiedlichen Zungen sprechenden Menschen voneinander gelernt haben. An den von dem Deutschen Sprachrat veranstalteten Wettbewerben, die der Suche nach dem schönsten deutschen Wort, nach ausgewanderten deutschen Wörtern und nach Wörtern (Pellens 1997: 256f.) mit Migrationshintergrund galten, haben in stattlicher Zahl sowohl D eutsche als auch - dank unseres weltweiten GoetheNetzes - viele Ausländer teilgenommen.

In den höheren Diskurswelten wie etwa der Religion wird bei der Suche nach dem Eigenem im Fremden gern die Einsicht aufgeboten, dass die drei großen monotheistischen Religionen des Christentums, des Islam und des Judentums Buchreligionen sind und in Abraham ihren gemeinsamen Stammvater finden. Vor allem im Bereich der K unst und der Literatur zeigt sich, dass künstlerische Stile und Ausdrucksformen, Regie- und D ramaturgiestrategien, K unstwerke und wissenschaftliche Erkenntnisse schon immer ein- und ausgewandert sind. Schon G oethe wusste, dass es keine patriotische Kunst, keine patriotische Wissenschaft gibt, dass beide wie alles Gute - „der ganzen Welt angehören und nur durch allgemeine freie Wechselwirkung aller ... gefördert werden" können. 


\section{D as Fremde im Eigenen - D as Ende der Nationalkultur?}

Wer das Eigene im Fremden sucht, sollte auch für das Fremde im Eigenen aufgeschlossen sein. In Zeitalter der Migration und der Globalisierung ist die Vorstellung von in sich geschlossenen Nationalkulturen fragwürdig geworden. In der Einsicht, dass sich klare Trennlinien zwischen Innen und Außen nicht mehr ziehen lassen, fragte das Goethe-Institut neulich auf einem Symposion auf der Museumsinsel in Berlin, ob wir überhaupt noch von einer deutschen Nationalkultur sprechen können. O hne die Antwort vorwegzunehmen, sei soviel gesagt, dass in allen Sparten der Kunst, auch der Sprache, immer mehr (auch) deutsch sprechende Künstler und Künstlerinnen am Werke sind, die selbst oder deren Vorfahren $\mathrm{Zu}$ wanderer sind. Als Beispiele seien nur der Filmregisseur Fatih Akin, die Rechtsanwältin und Autorin Seyran Ates und die Schriftstellerinnen Marica Bedrozic und Emine Sevgi Özdamar wie der Autor Ferudin Zaimoglu genannt. Was diese mit der Klarsicht einer anderen Herkunft sehen, spiegelt sich auch in ihrer Arbeit und Sprache wider.

\section{Europäische Bildungsziele}

\section{Empathie, Toleranz und Mehrsprachigkeit}

$\mathrm{Zu}$ den kulturellen Schätzen Europas gehört seit jeher die Vielzahl der Sprachen. Die Europäische Union hat sich zum Ziel gesetzt, die kulturelle und sprachliche Vielfalt zu respektieren und das kulturelle Erbe zu bewahren. Im Sinne dieser Aufgabe hat die Europäische Kommission das Jahr 2008 dem interkulturellen Dialog gewidmet. D as G oethe-Institut hat sich dem Projekt der Mehrsprachigkeit verschrieben, die eine der wichtigsten Voraussetzungen des interkulturellen Dialogs ist.

Auf den ersten Blick mag es paradox erscheinen, dass sich ein $\mathrm{Gefühl}$ der $\mathrm{Zu}$ sammengehörigkeit auf sprachliche und kulturelle Vielfalt gründen sollte. Wer wollte die Sprengkraft leugnen, die aus der kulturellen Vielfalt resultiert? Eingedenk der Tatsache, dass sprachliche, kulturelle und ethnische Vielfalt zugleich Quelle von Reichtum, aber auch von Spannungen ist, gilt es, die positiven Auswirkungen der Vielsprachigkeit Europas zu stärken. Könnte nicht eine bewusst gelebte kulturelle Vielfalt als ein mächtiges Gegengift gegen nationalistisch übersteigerte Identitäten wirken, die wiederholt zu zerstörerischen Kriegen geführt haben? (Europäische Kommission 2008: 6)

Wenn wir in Europa eine Nachbarschaft des G eistes begründen wollen, sollten wir uns auf gemeinsame Bildungsziele verständigen. Wissbegier, die Lust, sich auf die Welt einzulassen, Empathie für Menschen fremder Kulturen - all das sind Eigenschaften, die eine Vielfalt in der Einheit zu gewährleisten vermögen. Das Gleiche gilt für die Tugend der Toleranz und die Kompetenz der Mehrsprachigkeit. 
Nur derjenige wird Brücken zwischen den verschiedenen Kulturen und Religionen bauen können, der sich mit den anderen Menschen zu verständigen vermag.

Reisen bildet, heißt es so hübsch. Aber geographische Umtriebigkeit für sich allein weitet nicht den geistigen Horizont. So mancher Mensch verbringt jahrzehntelang die Sommerferien auf Mallorca und weiß gleichwohl nichts von spanischer Lebenskultur. Von einem Weltbürger erwarten wir, dass er die Lebensweisen und Lebenserfahrungen der Menschen anderer Kulturen erkundet, auf dass er sich in deren Vorstellungswelt hineinzufühlen vermag. Die Sprache ist der Schlüssel für das Verständnis der Welt. D arum lautet unsere Maxime: Mehrsprachigkeit bildet. Sprache ist nicht nur ein Mittel der Verständigung. Sprache ist Kultur.

D ie Wörter sind nicht nur Bestandteile unserer Sprache, sie gleichen vielmehr einem Netz von Befindlichkeiten und Denkbarkeiten. Sprache ist - so Wilhelm von Humboldt - auch Ausdruck der Verschiedenheit des Denkens, jede Sprache ist „auch eine Ansicht von der Welt“; denn die verschiedenen Sprachen sehen die Welt verschieden an (Humboldt 1, 60). Für den, der eine Fremdsprache erlernt, eröffnet sich eine "neue Art zu denken und zu empfinden“. Bei der Suche des Deutschen Sprachrats nach dem schönsten deutschen Wort, entschied sich eine Spanierin für „Fernweh“. Sie schrieb, dass dieses Wort das schönste deutsche Wort für sie sei, „weil es das Wort ist, das ich lebenslang gesucht habe. Bis ich angefangen habe, Deutsch zu lernen, habe ich dieses G efühl nicht benennen können. Es ist komisch, etwas zu spüren, und kein Wort dafür zu haben." (Limbach 2005: 76)

Einsprachigkeit macht einfältig, Mehrsprachigkeit stärkt G eist und Verstand, sie schafft Zugang zu den Wissensbeständen der Welt. D ie Liste der Vorzüge, die das Erlernen von Fremdsprache mit sich bringt, ließe sich mühelos fortsetzen. Aber ziehen wir die Summe: Die Mehrsprachigkeit ist eines der fruchtbarsten Bildungsziele, wenn es darum geht, Menschen zu Weltbürgern zu machen. Auch für dieses Ziel gilt, was Peter Ustinow für die Bildung allgemein gesagt hat:

„Bildung ist wichtig, vor allem wenn es gilt, Vorurteile abzubauen. Wenn man schon ein $\mathrm{G}$ efangener seines eigenen $\mathrm{G}$ eistes ist, kann man wenigstens dafür sorgen, dass die Zelle anständig möbliert ist."

\section{Die persönliche Adoptivsprache}

Eine von dem Präsidenten der europäischen Kommission und dem Kommissar für Mehrsprachigkeit, Leonard Orban, eingesetzte Gruppe von Intellektuellen hat sich $\mathrm{G}$ edanken darüber gemacht, wie die Mehrsprachigkeit auf den interkulturellen Dialog Einfluss nehmen kann. D ie Idee der persönlichen Adoptivsprache ist dem Kopf ihres Vorsitzenden Amin Malouf entsprungen und von der G ruppe, der anzugehören ich die Ehre habe, begeistert aufgenommen worden. Diese erscheint uns als ein Konzept, das zum gesellschaftlichen Zusammenhalt in der Europäischen Union beizutragen vermag (Europäische Kommission 2008). 
Frei sollen jeder Europäer und jede Europäerin eine besondere Sprache wählen können, die sich sowohl von der Mutter- als auch der internationalen Verkehrssprache unterscheidet. Während die Wahl der letzten weitgehend von den Bedürfnissen der Kommunikation diktiert werden dürfte, sollte die Entscheidung für die persönliche Adoptivsprache eher von persönlichen Beweggründen geleitet werden, etwa von der Familiengeschichte, der geographischen Nachbarschaft, emotionalen Bindungen, beruflichen Interessen und intellektueller Neugier. Hinter dem Konzept steht die Einsicht, dass sich der europäische Gedanke nicht nur auf die ge meinsamen Grundwerte des modernen Verfassungsstaats, sondern auch auf die Unterschiedlichkeit der Sprachen und Kulturen stützt. Jede Sprache - und sei die sie sprechende Sprachgemeinschaft noch so klein - ist Trägerin eines G edächtnisses, eines kulturellen Erbes und einer besonderen Ausdrucksfähigkeit. D arum ist keine unverzichtbar. Jede sollte mit Hilfe bilateraler Bande bewahrt werden.

Ein mögliches Missverständnis sei von vornherein ausgeräumt: Es geht bei dem Plädoyer für eine persönliche Adoptivsprache nicht darum, der englischen Sprache ihre Rolle als Instrument der weltweiten Kommunikation streitig zu machen. Die gegenwärtig herrschende Rivalität zwischen der englischen und den anderen europäischen Sprachen soll mit dem zweifachen, aber unterschiedlich intensiven Spracherwerb gerade überwunden werden. Was übrigens nicht ausschließt, dass der eine oder die andere die englische Sprache als persönliche Adoptivsprache in der Absicht wählt, über das „basic english" hinauszugelangen. Für die englische Sprache ist es gleichermaßen oder sogar besonders wichtig, dass sie ihre Stellung als Kultursprache behauptet und bewahrt, statt auf ihre Rolle als Instrument der internationalen Kommunikation festgelegt und verkürzt zu werden.

$D$ as Erlernen der persönlichen Adoptivsprache soll mit einem Vertrautwerden mit der Kultur, der Literatur, der G eschichte, der G esellschaft und mit den politischen Institutionen des Landes einhergehen, in dem die jeweilige Sprache gesprochen wird. Dieser vertiefte Spracherwerb zielt auf die Bildung der Persönlichkeit. Er trägt dazu bei, die Bereitschaft und die Fähigkeit zu entwickeln, sich in anderen Regionen und Geisteswelten zurechtzufinden. Nicht nur die Muttersprache hilft dem Menschen, sich seiner Eigenart zu vergewissern. Auch das Erforschen eines anderen sprachlichen und kulturellen Universums eröffnet neue Wege der Selbsterkenntnis. Mit den Worten „Vergleiche Dich! Erkenne, was D u bist!" regt Antonio Tasso zum Reisen an. Denn „inwendig“, so begründet Antonio seinen Rat,

„lernt kein Mensch sein Innerstes

Erkennen; denn er misst nach eigenem Maß

Sich bald zu klein und leider oft zu groß.

Der Mensch erkennt sich nur im Menschen, nur

D as Leben lehret jedem, was er sei."

Hinter dem Konzept der persönlichen Adoptivsprache steht letztlich ein neues Menschenbild, nämlich das Ideal eines weltoffenen Unionsbürgers, der Brücken 
zwischen der Kultur seines Herkunftslandes und der Länder, Regionen und Gemeinden zu schlagen weiß.

„Man kennt die Eigentümlichkeit einer Nation erst dann, wenn man sieht, wie sie sich auswärts beträgt." (Goethe)

\section{Literaturangaben}

Albrecht, Corinna (2003): Kulturwissenschaftliche Xenologie und Kulturkomparatistik. In: Wierlacher, Alois und Andrea Bogner: H andbuch interk ulturelle G ermanistik. Stuttgart: J. B. Metzler Verlag, 541-547.

Brodersen, Ingke/ Rüdiger D ammann (2003): Editorial. Auf der Suche nach einer Idee. In: Kafk a/ Z eitschritt für Mitteleuropa (11) 2003. Neues Europa, 4.

Europäische Kommission (2008): E ine lohnende Herausforderung - Wie die M ehrsprachigk eit zur Konsolidierung E uropas beitragen kann. V orschläge der von der E uropäischen Kommission eingerichteten Intellek tuellengruppe für den interkulturellen D ialog. Brüssel.

von Humboldt, Wilhelm: W ilhelm von H umboldts W erke 1903-1936, hg. von Albert Leitzmann. Berlin.

Huntington, Samuel P. (1996): Kampf der Kulturen. The Clash of Civilizations. D ie $\mathrm{N}$ eugestaltung der W eltpolitik im 21. Jahrhundert. München, Wien: Europaverlag.

Knopp, Hans-Georg (2007): Ein europäisches Verhältnis. In: Institut für Kulturpolitik der Kulturpolitischen G esellschaft (Hg.): Jahrbuch fur Kulturpolitik 2007. Thema: E uropäische Kulturpolitik, 69-78.

Limbach, Jutta (Hg.) (2005): D as schönste deutsche W ort. Ismaning: Hueber.

Malouf, Amin (2000): 0n Identity. London: Harvill.

Peisert, Hansgert (1978): D ie auswärtige Kulturpolitik der Bundesrepublik D eutschland. Stuttgart: Klett.

Pellens, Karl (1997): Im Fremden Eigenes? Zugänge zum Mittelalter. In: Geschichtsdidaktik. In: Stefan Weinfurter und Frank Martin Siefarth (Hg.): $\mathrm{V}$ erband der $\mathrm{H}$ istorik er D eutschlands e.V .. 41. D eutscher H istorik ertag in M ünchen, 17. bis 20. September 1996. Berichtsband. München, 256f.

Ratzinger, Joseph (2005): Was die Welt zusammenhält. Vorpolitische Grundlagen eines freiheitlichen Staates. In: Jürgen Habermas/ Joseph Ratzinger: D ialek tik der Säkularisierung - Ü ber V ernunft und R eligion. Freiburg: Herder, 40-60.

Wagner, Ulrich (1997): Psychologische Beiträge zur Erklärung des Fremden. In: G eschichtsdidaktik. In: Stefan Weinfurter und Frank Martin Siefarth (Hg.): 
V erband der H istorik er D eutschlands e.V .. 41. D eutscher H istorik ertag in M ünchen, 17. bis 20. September 1996. Berichtsband. München, 254-268.

Wierlacher, Alois (2004): Professionalität. Zur D iskussion eines Grundbegriffs und einer Grundbedingung interkultureller G ermanistik. In: Jahrbuch D eutsch als Fremdsprache. Intercultural German Studies. Sprachenpolitik. Band 30. Heidelberg: Carl Winter Universitätsverlag, 17-33. 


\title{
Rechtsstaatsdialog mit der VR China - Fortschritt oder Feigenblatt?
}

\author{
Christiane C. W endehorst
}

Das Jahr 2008 ist für die Volksrepublik China in vielerlei Hinsicht ein besonderes Jahr. ${ }^{1}$ D amit meine ich nicht einmal in erster Linie die Olympischen Spiele in Peking, die am 8. 8. um 8.08 Uhr begonnen haben. Vor allem kann China 2008 auf dreißig Jahre Politik der Öffnung gegenüber dem Westen zurückblicken, die im Jahre 1978 von Deng Xiaoping eingeleitet wurde. Viel, sehr viel hat sich inzwischen getan. China ist zu einem der wichtigsten Handelspartner D eutschlands geworden. So weist die Handelsstatistik des Jahres 2007 China bei den Importen an dritter Stelle - hinter Frankreich und den Niederlanden - und bei den Exporten an elfter Stelle aus. ${ }^{2}$ D er Flugverkehr zwischen beiden Staaten nimmt fast täglich zu. Viele Tausende chinesischer Studierender kommen nach D eutschland, um hier ein Studium zu absolvieren. ${ }^{3}$ Bundes- und Landespolitiker bereisen China mit einer Frequenz, die es auch eingeweihten Stellen manchmal schwer macht, den Überblick zu behalten, wer gerade alles dort ist. Und dennoch: 2008 ist auch deswegen ein besonderes Jahr, weil in einem Ausmaß wie seit 1989 kaum mehr gehabt, deutlich geworden ist, dass da auch noch etwas Trennendes war, was die Harmonie

\footnotetext{
1 D as vorliegende Manuskript wurde im Juli 2008 eingereicht. Spätere Entwicklungen konnten daher nicht berücksichtigt werden.

2 Vgl. Pressemitteilung Nr. 116 des Statistischen Bundesamtes D eutschland vom 17. März 2008.

3 So waren nach Auskunft des Auswärtigen Amts im Januar 2008 ca. 27.000 chinesische Studenten im Rahmen von ungefähr 400 Hochschulkooperationen an deutschen Hochschulen eingeschrieben. Siehe auch http:/ / www.auswaertiges-amt.de.
} 
trübt. Was D eutschland betrifft, hatte sich dieses Trennende schon im September 2007 angedeutet, als China als Reaktion auf den Empfang des Dalai Lama durch Bundeskanzlerin Merkel den deutsch-chinesischen Rechtsstaatsdialog für einstweilen ausgesetzt erklärte. Erst ganz kürzlich wurde er zögernd wieder aufgenommen. ${ }^{4}$

\section{I. Überblick über die laufenden Aktivitäten}

Worum handelt es sich bei diesem deutsch-chinesischen Rechtsstaatsdialog? Die Antwort ist leider gar nicht so einfach, weil es sich um einen vielschichtigen Prozess handelt, der wenigstens ursprünglich auf drei Säulen ruhte.

\section{Entwicklungstechnische Zusammenarbeit}

a) Koordinierte E ntwidk lungshilfe

Die zeitlich gesehen erste Säule, die vielfach gar nicht mit dem Begriff „Rechtsstaatsdialog" in Verbindung gebracht wird, ist die Rechtsberatung im Rahmen der deutschen Entwicklungshilfe. Soweit sie politisch koordiniert erfolgt, geschieht dies unter der Ägide des Bundesministeriums für wirtschaftliche Zusammenarbeit und Entwicklung (BMZ). ${ }^{5}$ Die konkrete Durchführung obliegt zum größten Teil der Deutschen Gesellschaft für Technische Zusammenarbeit und Entwicklung (GTZ), ${ }^{6}$ einem privatwirtschaftlichen Bundesunternehmen mit Sitz in Eschborn, zu geringfügigen Teilen auch anderen Vertragspartnern, wie etwa der Internationalen Weiterbildungs- und Entwicklungs $\mathrm{G} \mathrm{mbH}$ (InWEnt). ${ }^{7}$ O bgleich der Begriff der "technischen Zusammenarbeit und Entwicklung" auf den ersten Blick nicht gerade auf Zusammenarbeit im Rechtsbereich schließen lässt, verbirgt sich hinter ihm eine umfangreiche Beratungs- und Schulungstätigkeit auf den verschiedensten G ebieten des Rechts, die von der allgemeinen Erwachsenenbildung über Weiterbildungsprogramme für Justiz und Verwaltung reicht, bis hin zur Beratung von Regierung und Nationalem Volkskongress bei konkreten Vorhaben der G esetzgebung. Auf zahlreiche $\mathrm{G}$ esetze der neueren Vergangenheit, so namentlich auf die Gesetzgebung im Bereich des Verwaltungsrechts sowie auf das neue Sachenrechtsgesetz von 2007, ist auf diese Weise Einfluss ausgeübt worden.

Wie groß dieser Einfluss wirklich war, lässt sich freilich im Nachhinein nicht zuverlässig feststellen. Auf der Seite der beteiligten deutschen Akteure wird er verständlicherweise gerne betont, ja werden die erlassenen $\mathrm{G}$ esetzeswerke gar im We-

4 Die achte Rechtsstaatskonferenz des deutsch-chinesischen Rechtsstaatsdialogs fand, nach einer Absage von chinesischer Seite im Herbst 2007, im April 2008 in München statt.

${ }^{5}$ Nähere Informationen unter: http:/ / www.bmz.de/ de/ laender/ partnerlaender/ china/ (Zugriff am 11. Juli 2008).

${ }^{6} \mathrm{http}: / /$ www.gtz.de.

7 http:/ / www.inwent.org. 
sentlichen als Produkt deutscher Rechtsberatung dargestellt. ${ }^{8} \mathrm{D}$ as deutsche Recht hat zwar in China traditionell ein besonders hohes Ansehen und die Zusammenarbeit mit deutschen Juristen wird gerne gesucht, tatsächlich aber ist China gar nicht darauf angewiesen, von deutschen Entwicklungshilfeorganisationen darüber informiert zu werden, wie westliche Gesetze funktionieren, und hört China auch nicht in erster Linie auf die deutsche Stimme.

Nicht zu übersehen ist, dass vor allem das angloamerikanische Common Law mit unvorstellbarem finanziellem Einsatz um Einfluss auf chinesische G esetzgebung ringt. ${ }^{9}$ So betonte auch die Bundesregierung in einer Antwort auf eine Große Anfrage zur China-Politik vom 6. Juni 2008 die Funktion des Rechtsstaatsdialogs, einen Ausgleich für den großen Einfluss des angloamerikanischen Rechts herzustellen. ${ }^{10}$ China selbst hat demgegenüber schon lange Experten in fast alle Länder entsendet, die Übersetzungen ausländischer Gesetze und präzise Berichte über deren Wirkungsweise liefern. D iese Informationen nutzt der chinesische G esetzgeber als „Werkzeugkasten“ und "Materiallager", um sich daraus das jeweils anscheinend Beste und Passendste herauszusuchen, miteinander zu kombinieren und schließlich einen eigenen chinesischen Weg zu gehen. Nehmen wir als Beispiel das neue chinesische Sachenrecht, ${ }^{11}$ das gerne als Erfolg deutscher Rechtsberatung gefeiert wird, so fällt auf, dass als spezifisch deutsch eigentlich nur die Abtretung eines Herausgabeanspruchs als Übergabesurrogat gewertet werden kann, während das Abstraktionsprinzip und die publizitätslose Sicherungsübereignung als international markanteste Merkmale des deutschen Sachenrechts wohl gerade nicht übernommen wurden. ${ }^{12}$

\section{b) U nk oordinierte E ntwidk lungshilfe}

Über die unmittelbar vom BMZ koordinierten Rechtsberatungs- und Weiterbildungsprogramme hinaus existieren im Rechtsbereich unzählige bilaterale Kooperations- und Hilfsprogramme, die von anderen öffentlichen oder nichtöffentlichen

\footnotetext{
8 Vgl z.B. Julius, In der Tradition des deutschen Rechts, Welt O nline vom 13. März 2007.

9 Siehe SchulteKulkmann, Der Einfluss westlicher Rechtsberatung auf die Rechtsreformen in der Volksrepublik China: Zur Rolle von Akteueren und Interessen in der chinesisch-westlichen Rechtsberatung, abrufbar unter: http:// www.chinapolitik.de/ studien/ china_analysis/ no_13.pdf, 15ff. (Zugriff am 21. Juli 2008).

10 Siehe „Antwort der Bundesregierung auf die Große Anfrage der Abgeordneten Jürgen Trittin, Marieluise Beck (Bremen), Volker Beck (Köln), weiterer Abgeordneter und der Fraktion BÜND NIS 90/ DIE GRÜNEN zur China-Politik der Bundesregierung" - Drucksache 16/9513 vom 6. Juni 2008, Frage 29.

11 Übersetzung mit Anmerkungen bei Zhou/ Qi/ L ohsse/ Liu, ZChinR 2007, 68-117; M ünzel, Chinas Recht 2007.4, 16.3.07/ 1, http:/ / www.mpipriv.de/ shared/ data/ pdf/ sachenrechtsg2007.pdf; D e gen/ L iu in RIW Special 1 zu Heft 11, 2007.

$12 \mathrm{Zu}$ Einzelheiten siehe Baumann, D as neue chinesische Sachenrecht - Seine Entwicklung unter Einfluss des deutschen Rechts (2006), Julius/ Rehm, D as chinesische Sachenrecht tritt in Kraft: Revolution oder Viel Lärm um Nichts?, ZV glRWiss 106 (2007), 367-414 und W endehorst, Warenverkehr mit der VR China - viel Neues durch das neue Sachenrecht?, ecolex 2008, 392-395.
} 
Christiane C. Wendehorst

Stellen getragen werden. Ministerien, nachgeordnete Verwaltungseinheiten von Bund und Ländern, Gerichtshöfe, Berufsvereinigungen von Justiz und Anwaltschaft, usw. leisten hier einen wichtigen Beitrag.

Als besonders gelungenes Beispiel solcher Arbeit darf etwa die Mitwirkung beim Aufbau eines chinesischen Patentwesens und Patentamts durch Experten des damaligen D eutschen Patentamts (heute: Deutsches Patent- und Markenamt) sowie des Münchener Max-Planck-Instituts für geistiges Eigentum in den 80er und 90er Jahren genannt werden. G erade an diesem Beispiel zeigt sich übrigens ein Charakteristikum der Arbeit mit China: Weniger abstrakte und anonyme Beratungsprogramme, sondern vielmehr individuelle Führungspersönlichkeiten sind es, was den Aufbau des Rechtsstaats vorantreibt. So wäre etwa der Aufbau des chinesischen Patentamts nicht geglückt, wenn deutsche Stellen damals nicht viel Zeit und Mittel in die intensive Ausbildung einiger hochbegabter chinesischer Stipendiaten gesteckt hätten, allen voran Tian Lipu, den heutigen Leiter des chinesischen Patentamts, der fast akzentfrei Deutsch spricht und sich besser mit bayerischer Küche auskennt als die meisten seiner Münchener Kollegen.

In diesem Kontext ist letztlich auch das Deutsch-Chinesische Institut für Rechtswissenschaft zu sehen, das die Universität Göttingen gemeinsam mit der Universität Nanjing betreibt und das ich - gemeinsam mit Herrn Kollegen Starck von 2000 bis 2008 geleitet habe. ${ }^{13}$ Es wurde 1988/ 89 offiziell gegründet, geht in seinen Anfängen aber bereits auf die frühen 1980er Jahre zurück. Es handelt sich dabei um eine in Europa bislang einzigartige Institution, die mit drei Veröffentlichungsreihen, mehreren Studiengängen und zahlreichen internationalen Symposien einen wesentlichen akademischen Beitrag zum Rechtsdialog leistet. Zu den wichtigsten Aufgaben des Instituts gehörte stets die Ausbildung einer relativ kleinen G ruppe handverlesener junger chinesischer Spitzenjuristen und Spitzenjuristinnen, die über drei Jahre hinweg eine hervorragende Grundausbildung im deutschen Recht erhalten und die ihr Studium mit einem deutschen wie einem chinesischen Magistergrad abschließen. Unsere Absolventen und Absolventinnen finden sich heute in führenden Positionen der Wirtschaft, Hochschule, Politik und Verwaltung. Einige kommen auch zurück und bekleiden hochrangige Posten in D eutschland, wie etwa Bu Yuanshi, die heute eine deutsche W3-Professur für Rechtswissenschaft in Freiburg bekleidet. D urch solche und andere Programme zur Förderung der Hochschulzusammenarbeit ${ }^{14}$ sollen junge Juristen mit fundierten Kenntnissen ausgestattet werden und so bei einer Rückkehr nach China eine Veränderung „von innen“ durch ausgezeichnete Kenntnisse beider Rechtsordnungen be wirken können. So betonte auch der damalige Bundespräsident Johannes Rau - in Übereinstimmung mit den Zielsetzungen des deutsch-chinesischen Instituts für

13 Siehe auch: http:/ / lehrstuhl.jura.uni-goettingen.de/ kontakte/ institut1.html.

14 Von den derzeit ca. 400 deutsch-chinesischen Hochschulkooperationen haben nur wenige die $\mathrm{Zu}$ sammenarbeit auf dem G ebiet der Rechtswissenschaften zum Inhalt. Weitere Projekte beschäftigen sich beispielsweise mit technischen oder künstlerischen Themen. Dazu Rogler, Deutsch-chinesische Studienprogramme: Analyse und Empfehlungen, Beiträge zur Hochschulpolitik 8/ 2005. 
Rechtswissenschaft - bei seiner Rede anlässlich der Verleihung der Ehrendoktorwürde der Universität Nanjing im September 2003, dass hochqualifizierte chinesische Juristen als „Multiplikatoren deutschen und chinesischen Rechtsdenkens" wirken und dadurch mithelfen sollen, eine „lebendige Brücke zwischen den Rechtskulturen" zu schlagen. ${ }^{15}$

\section{Menschenrechtsdialog}

Gleichsam am anderen Ende des Spektrums steht der deutsch-chinesische Menschenrechtsdialog, der auf offizieller Ebene federführend vom Auswärtigen Amt betrieben wird. Seiner Natur nach handelt es sich dabei um einen hochpolitischen Dialog, der nur zu einem kleinen Teil öffentlich ausgetragen, ganz überwiegend jedoch auf den ganz eigenen Wegen der Diplomatie betrieben wird. G roße Symposien, gemeinsame Aktionsprogramme usw. sind hier eher selten. Soweit sie überhaupt stattfinden, sind sie auf formell nichtstaatliche Träger, wie die FriedrichEbert-Stiftung, die Konrad-A denauer-Stiftung, die Chinesische Stiftung zur Förderung der Menschenrechte oder die Chinesische G esellschaft zur Förderung Internationaler Verständigung ausgelagert.

O ffiziell erklärtes Ziel dieses sehr sensible Themen ansprechenden Dialogs ist es, gegenseitiges Verständnis für Menschenrechte zu schaffen. D ie vorsichtige Vermittlung zwischen den oftmals unterschiedlichen deutschen und chinesischen Auffassungen der Menschenrechte bedarf nicht des „ausgestreckten belehrenden Zeigefingers", sondern vielmehr der G esprächsbereitschaft beider Partner. ${ }^{16}$ D enn nicht Anklage, sondern die D iskussion vieler Themen - wie z.B. „die Unterschiede zwischen der östlichen und westlichen Hemisphäre und der weltweiten Diskussion um Menschenrechte", "die Gleichstellung von Frauen in den sich wandelnden $\mathrm{Ge}$ sellschaften Chinas und D eutschlands“ oder „Menschenrechte und Bürgergesellschaft" - steht im Mittelpunkt des Dialogs und soll die positive Entwicklung zu einer modernen, die Menschenrechte achtenden G esellschaft beitragen. ${ }^{17} \mathrm{Zu}$ einem solchen Dialog gehört selbstverständlich auch die Würdigung der bereits erreichten Fortschritte in der chinesischen Menschenrechtsentwicklung. Die Möglichkeit zu freier Meinungsäußerung im privaten Bereich, zu Mobilität und individuellen beruflich-wirtschaftlichen Chancen, auch die Anstrengungen der chinesischen Regierung zu vielseitigen Reformen im Rechtsbereich sind aus Sicht der Bundesregie-

\footnotetext{
15 Vgl. Das Rechtsstaatsprinzip - Voraussetzungen für eine moderne Gesellschaft - Rede von Bundespräsident Johannes Rau in der Universität Nanjing vom 13. September 2003, erhältlich unter http:/ / www.bundespraesident.de (Zugriff am 8. Juli 2008).

${ }^{16}$ So Prof. Dr. Herta D äubler-G melin in der Eröffnungsansprache des achten D eutsch-Chinesischen Menschenrechtsdialogs in Berlin im O ktober 2006.

17 Publikationen der Beiträge zum vierten („Gleichstellung von Frauen in den sich wandelnden Gesellschaften“), sechsten („Menschenrechte und Bürgergesellschaft"), siebenten („Theorie und Praxis des Menschenrechtsschutzes“) und achten („Menschenrechte und Justiz“) Symposium sind unter http:/ / www.feschina.net/ Publikationen.asp erhältlich (Zugriff am 22. Juli 2008).
} 
rung ein großer Fortschritt, 18 deren Auswirkungen im täglichen Leben vieler chinesischer Bürger nicht zu verkennen sind. Von chinesischer Seite wird die Aufnahme des Begriffs „Menschenrechte“ in die Verfassung im Jahre 2004 gar als „Meilenstein in der Entwicklung der Menschenrechte in China" gefeiert,19 die Umsetzung dieser Verfassungsänderung lässt aus deutscher Sicht jedoch zu wünschen übrig. ${ }^{20}$ Mit Spannung ist die Zeit nach den Olympischen Spielen und die voraussichtlich damit verbundene Lockerung mancher einschränkender Vorschriften und die erhoffte Erweiterung des Schutzes der Menschenrechte zu erwarten.

Wie empfindlich dieser auf diplomatischer Ebene geführte Dialog auf Erschütterungen reagiert, konnte man ebenfalls im Herbst letzten Jahres an den selbstbewussten Reaktionen von chinesischer Seite nach dem Empfang des Dalai Lama durch Bundeskanzlerin Merkel sehen. D as für D ezember 2007 in Peking geplante Treffen wurde erstmals seit Bestehen des Menschenrechtsdialogs abgesagt und dieser bislang nicht wieder aufgenommen. ${ }^{21}$ China lasse sich keine „Einmischung in die inneren Angelegenheiten " gefallen und ziehe daher schwere Konsequenzen.22 Jedoch scheint sich eine Entspannung der Lage abzuzeichnen: Beim Besuch des Bundesaußenministers Steinmeier in China im Juni 2008 wurde sowohl von deutscher als auch von chinesischer Seite die Absicht erklärt, den bilateralen Menschenrechtsdialog nach den Olympischen Spielen in der zweiten Hälfte des Jahres wieder aufzunehmen. ${ }^{23}$ Dies wäre aus Sicht aller beteiligten Akteure wünschensund erstrebenswert, damit die jahrelang erarbeitete, bislang gute G esprächsatmosphäre nicht abkühlt und begonnene D iskussionen weitergeführt werden können.

Auch die Arbeit rein nichtstaatlicher Gruppen wie amnesty international (AI) oder Tibet-Initiative D eutschland e.V. möchte ich in diesem Zusammenhang nicht herunterspielen, wenngleich Reaktionen von chinesischer Seite, die dieser Art von Kooperationen und Initiativen den Charakter eines Dialogs geben würden, doch auf Einzelfälle beschränkt bleiben. Ihre Berichte und Recherchen sind umfangreich und oftmals, wenn von offizieller chinesischer Seite keine Informationen vorliegen, die einzige Möglichkeit, sich über die Verhältnisse zu informieren. Ebenfalls leisten diese Organisationen viel Öffentlichkeitsarbeit, um über die Menschenrechtsentwicklung in China zu berichten, wenngleich die Berichterstattung meist negativ ausfällt und die positiven Fortschritte kaum Beachtung finden.

\footnotetext{
18 Siehe die „Antwort der Bundesregierung“ - FN 10, Frage 1.

19 Siehe die Rede „Erfolge und Position der chinesischen Regierung in Menschenrechtsfragen und Möglichkeit der chinesisch-deutschen Kooperation in Menschenrechtsfragen" von Ding Feng, Stv. Abteilungsleiter für Politik und Recht des Rechtsbüros beim Staatsrat, gehalten im Rahmen des achten Menschenrechtsdialogs im O ktober 2006.

20 Siehe die "Antwort der Bundesregierung" - FN 10, Frage 2.

21 Siehe die "Antwort der Bundesregierung" - FN 10, Frage 28.

22 Siehe z.B. die Artikel „China lässt Treffen mit Bundesregierung platzen“, focus online und "China sagt Menschenrechtsdialog ab“, FAZ.net, beide vom 13. O ktober 2007.

23 Siehe u.a. die Mitteilung des Auswärtigen Amts zu BM Steinmeiers China-Reise im Juni 2008.
} 


\section{Rechtsstaatsdialog im engeren Sinn}

Die von mir bislang gezeichnete Säulenstruktur ist einerseits zutreffend, entspricht aber andererseits heute nicht mehr ganz der offiziellen D arstellung, weil die bislang beschriebenen Aktivitäten inzwischen eine Umdeutung erfahren haben und fast ausnahmslos in den sogenannten „D eutsch-Chinesischen Rechtsstaatsdialog“ im engeren Sinn integriert worden sind.

\section{a) $\mathrm{H}$ intergrund}

Dieser Rechtsstaatsdialog geht zurück auf eine Vereinbarung zwischen dem früheren Bundeskanzler G erhard Schröder mit seinem chinesischen Amtskollegen Zhu Rongji vom November 1999. Am 30. Juni 2000 unterzeichneten die Justizminister beider Länder, genauer gesagt die Bundesjustizministerin und der Leiter des chinesischen Rechtsamts beim Staatsrat, die „Deutsch-Chinesische Vereinbarung zu dem Austausch und der Zusammenarbeit im Rechtsbereich“. ${ }^{24}$ Diese beiden Ministerien sind auch für den gesamten Rechtsstaatsdialog federführend.

Nach der Vereinbarung soll der Dialog über den Aufbau des Rechtsstaats im Geist des Prinzips der Gleichberechtigung, der wechselseitigen Achtung und auf der $\mathrm{G}$ rundlage der $\mathrm{G}$ egenseitigkeit geführt werden. Bei dieser Eingangsformel handelt es sich um eine übliche Formel, auf die China beim Abschluss internationaler Vereinbarungen stets allergrößten Wert legt. Sie markiert an dieser Stelle aber auch mehr als eine bloße Floskel, weil sie einen Paradigmenwechsel indiziert, weg von der Entwicklungshilfe und hin zum echten Dialog. Schon Bundespräsident Rau wies in seiner Rede darauf hin, dass diese Dialogfähigkeit D eutschland und China im Besonderen verbinde, der Rechtsstaatsdialog „keine Trockenübung“ sei und dieser in China ernst genommen werde. Denn das G espräch baue auf Respekt vor der unterschiedlichen Entwicklung der Länder auf und finde in der Überzeugung statt, dass sich China „auf dem Weg zu mehr Demokratie und Rechtsstaatlichkeit" befinde.

Inhaltlich war die Vereinbarung von 2000 auf den ersten Blick eher unspektakulär: Sie listete eine Reihe von Rechtsgebieten auf, in denen in den folgenden Jahren verstärkt die Zusammenarbeit gesucht werden sollte: im Bereich des Verwaltungsrechts, des Zivil- und Handelsrecht, des Wirtschaftsrechts und des Arbeitsund Sozialrechts. Auch „Regelungen zur Durchführung und Durchsetzung der Gesetze sowie deren Kontrolle, zum Schutz der verbürgten Rechte und Interessen der Bürger: Regelungen zur Bekämpfung der Wirtschaftskriminalität und Korruption" waren in der Vereinbarung enthalten.

Ausdrücklich herausgestellt wurde, dass im Verlauf des Dialogs eine „schrittweise Erweiterung" der Rechtsgebiete möglich sei, was durch die Erweiterung der Schwerpunkte auf die „Achtung und Schutz der Menschenrechte durch den Staat"

24 Informationen hierzu und zu den darauf aufbauenden Zweijahresprogrammen sind beim Bundesministerium für Justiz erhältlich: http:/ / www.bmj.de. 
und die "D eutsch-Chinesische Hochschulzusammenarbeit im Rechtsbereich" erfolgte. Sensible Punkte werden in der Vereinbarung eher verklausuliert angesprochen. Immerhin findet sich aber die gemeinsame Forderung, dass "das Volk umfangreiche Rechte und Freiheiten nach dem Gesetz genießt, dass die Menschenrechte respektiert und garantiert und alles staatliche Handeln gesetzmäßig durchgeführt werden" ${ }^{25}$ Insbesondere die deutsche Seite wollte damit dokumentiert wissen, dass die rechtlichen Grundlagen für die weitere wirtschaftliche Entwicklung Chinas nicht von den grundlegenden Rechten der Bürger, Achtung der Menschenrechte, Informations- und Meinungsfreiheit und Rechtsstaatlichkeit des Verwaltungshandelns abzutrennen sind. D enn, dies hob auch der ehemalige Bundespräsident Rau in seiner Rede in der Universität Nanjing hervor, die Themen Rechtsstaat und Menschenrechte sind unmittelbar miteinander verbunden.

D ie Vereinbarung vom 30. Juni 2000 ist insgesamt inhaltlich weniger wichtig als die ihr folgenden Z weijahresprogramme zu ihrer D urchführung, die von deutscher und chinesischer Seite jeweils 2001, 2003, 2005 und theoretisch 2007, faktisch 2008, ausgehandelt und unterzeichnet worden sind und die jeweils die bilateralen Maßnahmen der folgenden zwei Jahre beinhalten. Hier ist schrittweise eine Konkretisierung erkennbar, und die Zweijahresprogramme von 2005 und von 2008 weisen bereits an prominenter Stelle die Überschrift „Staatliche Achtung und Schutz der Menschenrechte" aus. D as D eutsch-Chinesische Institut für Rechtswissenschaft der Universitäten G öttingen und Nanjing ist übrigens in den Zweijahresprogrammen seit 2003 jeweils ausdrücklich als Träger der „D eutsch-Chinesischen Hochschulzusammenarbeit im Rechtsbereich" genannt und nimmt in den bilateralen Vereinbarungen beider Staaten eine herausgehobene Stellung ein.

\section{b) Rechtsstaatsk onferenzen}

Herzstück des Rechtsstaatsdialogs sind jährliche so genannte Rechtsstaatskonferenzen, die alternierend jeweils einmal in China und einmal in Deutschland stattfinden. Bislang haben acht solcher Konferenzen stattgefunden. ${ }^{26}$ Diese Symposien dienen dem gegenseitigen Erfahrungsaustausch und als Ergänzung zu den unter dem Jahr laufenden Dauer- und Einzelprojekten. Die Themenschwerpunkte der bisherigen Rechtstaatskonferenzen waren breit gefächert.

D ie Eröffnungsveranstaltung im Juni 2000 in Peking fand zum Thema „Rechtsbindung der Verwaltung und Individualrechtsschutz" statt. Im O ktober 2001 stand der „Rechtliche Rahmen für die untemehmerische Tätigkeit in der Marktwirtschaft

\footnotetext{
25 Siehe Punkt 2. der D eutsch-Chinesischen Vereinbarung zu dem Austausch und der Zusammenarbeit im Rechtsbereich vom 30. Juni 2000.

${ }^{26}$ Nähere Informationen zu den ersten sechs Konferenzen in der von der GTZ herausgegebenen Dokumentation „Der Deutsch-Chinesische Rechtsstaatsdialog - Ein Überblick“, abrufbar unter: http:/ / www.gtz-legal-reform.org.cn/ en/ Broschuere\%20RSD \%20dt.pdf; auch in der ZChinR in Heft 4/ 2000 (D rewes), Heft 3-4/ 2002 (E ckelman), 4/ 2003 und 3/ 2005 (beide Pißler) sind Tagungsberichte zu finden.
} 
- Staatliche Regulierung und Schutz der legitimen Rechte und Interessen der Bürger und der Unternehmen" im Vordergrund der in Berlin gehaltenen Konferenz. Das dritte Symposium in Peking im Mai 2002 behandelte das Thema der „Rechtsstaatlichen O rdnung der Marktwirtschaft - Förderung der Kreditwürdigkeit und der Rechtssicherheit für Bürger und Unternehmen“. D as darauf folgende Symposium - wiederum in Berlin - im November 2003 war „Rechtsfragen, Politik und globalen Nutzungsmöglichkeiten der Informationstechnologie" gewidmet. Das fünfte und sechste Symposium im Mai 2004 in Peking bzw. im Juni 2005 in Hamburg behandelten die Themen „Ausübung der Notstandsbefugnisse des Staates und Schutz der Rechte der Bürger" und "O ffenlegung von Regierungs- und Verwaltungsinformationen". Bei der siebenten Rechtsstaatskonferenz in Xi'an im Mai 2006 standen die „Ausübung von Verwaltungszwang und die Rechte der Bürger" im Mittelpunkt der Diskussion. D as achte und bisher letzte Symposium in München, welches ursprünglich für Herbst 2007 angesetzt war, jedoch - wie bereits erwähnt - von chinesischer Seite kurzfristig abgesagt worden war, konnte im Mai 2008 in München unter dem Thema „Effektiver Schutz geistigen Eigentums als Element des Rechtsstaats" stattfinden.

D iese Rechtsstaatskonferenzen sind keine öffentlichen Konferenzen, sondern auf beiden Seiten einem relativ kleinen Kreis von Teilnehmenden jeweils unter der Leitung der Bundesjustizministerin und des Ministers des Rechtsamts beim Staatsrat vorbehalten. D ieser Umstand führt oft zu dem Vorwurf, der Rechtsstaatsdialog finde im Verborgenen statt und sei daher intransparent. ${ }^{27}$

Die personelle Zusammensetzung wechselt mit der Thematik, die jeweils im Mittelpunkt steht. D ie Konferenzen dauern in der Regel jeweils zwei Tage, wobei grob gesprochen der erste Tag einführenden Fachvorträgen, der zweite Tag der Diskussion in kleineren Arbeitsgruppen gewidmet ist. Im Laufe der Jahre hat eine gewisse Verschiebung der $\mathrm{G}$ ewichte zugunsten der Arbeitsgruppen stattgefunden.

Neben diesen gleichsam hochoffiziellen Rechtsstaatskonferenzen, die eher die Form von Staatsbesuchen haben, gibt es auch noch eine kleinere Zahl „halboffizieller" Konferenzen, die sich zwar thematisch ausdrücklich auf die Vereinbarung von 2000 bzw. auf die jeweils gültigen Zweijahresprogramme beziehen, die aber ohne Anwesenheit höchster Politiker beider Staaten stattfinden.

\section{c) W eitere A k tivitäten}

Eines der großen Probleme des Rechtsstaatsdialogs war es von Anfang an, dass aus formalen Gründen das Bundesjustizministerium zuständig sein musste, um die Gleichberechtigung beider Partner zu betonen und vom Aspekt der Entwicklungshilfe wegzukommen, andererseits den sensibel-diplomatischen Bereich zu verlassen

${ }^{27}$ Näheres hierzu und die Auflistung weiterer Kritikpunkte finden sich bei L evy, Die deutsche Regierung hat gewechselt - der D eutsch-Chinesische Rechtsstaatsdialog geht weiter, China aktuell 5/ 2006, $64 f f$. 
und sich auf eine konkretere Arbeitsebene in der Sache zu begeben. Jedoch ist das BMJ weder finanziell noch personell hinreichend ausgestattet, um einen breiten D ialog in Rechtsfragen wirklich zu tragen. Sondermittel aus dem Haushalt für den Rechtsstaatsdialog wurden nicht oder nur in vernachlässigbarem Umfang zugewiesen. Zugleich bestand natürlich auch ein Bedürfnis und war es ein G ebot der Vernunft, die schon seit vielen Jahren auf den unterschiedlichsten Ebenen laufenden Aktivitäten im Rechtsbereich zu integrieren. So kommt es, dass letztlich das D reiSäulen-Modell partiell aufgegeben und die bislang unter dem Banner der Entwicklungszusammenarbeit und der politischen Diplomatie laufenden Aktivitäten dem Rechtsstaatsdialog mehr oder weniger einverleibt wurden. Unter dem großen Dach des Rechtsstaatsdialogs segeln daher nunmehr auch Kooperationsprojekte, die viel älter sind als der Rechtsstaatsdialog selbst und die mindestens ursprünglich einem ganz anderen Konzept folgten. Prominentes Beispiel ist der bereits oben dargestellte D eutsch-Chinesische Menschenrechtsdialog, welcher seit 1999 in jährlichen Tagungen stattfindet und demnächst fortgesetzt werden soll. ${ }^{28}$ Auch andere Projekte entstanden ebenfalls schon in den Achtziger- und Neunzigerjahren und wurden in den Rechtsstaatsdialog integriert. ${ }^{29}$

\section{Tragende Prinzipien}

Was ist aber nun dieses eigene Konzept des Rechtsstaatsdialogs im engeren Sinn, inwieweit geht er über bereits Vorhandenes hinaus?

\section{A bsolute Parität: D as Konzept der „dritten Spur“}

Einer der Grundgedanken bei Aufnahme des Rechtsstaatsdialogs im engeren Sinn war die Einfügung einer „dritten Spur“ zwischen Entwicklungszusammenarbeit und D iplomatie. Jede dieser Kooperationsschienen ist ja durch eine eigene Rhetorik und eigene Strategien gekennzeichnet. So ist die Entwicklungszusammenarbeit traditionell dadurch charakterisiert, dass China auf seinem Status als Entwicklungsland beharrt und sich auch bemüht, seine zentrale Rolle in der G ruppe der G 77 der Entwicklungsländer beizubehalten. ${ }^{30} \mathrm{D}$ ies hat entsprechende Konsequenzen für die Finanzierung der Maßnahmen, die praktisch ausschließlich von deutscher Seite erfolgt, aber auch Konsequenzen für den Status innerhalb der Kooperation, in der die chinesischen Partner sich gerne als diejenigen darstellen, die vom fortschrittlicheren Westen lernen wollen. Diese Haltung auch im Rechtsstaatsdialog beizube-

\footnotetext{
28 Siehe bereits oben unter 2.

29 Z.B. das Projekt „Regelwerke über die Lösung von Arbeitsstreitigkeiten in Unternehmen“, welches schon seit 1987 läuft sowie auch schon abgeschlossene Projekte, z.B. das Projekt zur „Fortbildung der auf dem G ebiet des Außenhandel tätigen Juristen“, welches von 1997 bis 2004 lief. Eine Übersicht über einzelne - auch abgeschlossene - Aktivitäten bietet die in FN 24 erwähnte D okumentation. 30 Siehe die „Antwort der Bundesregierung" - FN 10, Frage 84.
} 
halten wäre nicht zielführend, da es nicht darum geht, deutsche Rechtsvorstellungen zu exportieren.

Die diplomatische Schiene ist im Gegenteil dazu von denkbar großem Selbstbewusstsein der Volksrepublik, einem ständigen Mitglied im UN-Sicherheitsrat, geprägt, das sich als Weltmacht versteht und sich gute Ratschläge und Einmischungen von außen entschieden verbittet. ${ }^{31} \mathrm{~K}$ eine der beiden Varianten, die übrigens meiner Erfahrung nach in fast jedem Kontakt mit chinesischen Partnern zum Tragen kommen, schafft optimale Bedingungen für einen fruchtbaren Dialog über ein so sensibles Thema wie Rechtsstaatlichkeit.

Es war daher nur konsequent, den Rechtsstaatsdialog gleichsam als dritte Schiene zwischen den beiden anderen Extremen einzufügen. D er Rechtsstaatsdialog ist gekennzeichnet durch den G eist der G leichberechtigung, welcher in Punkt 1. der Vereinbarung von 2000 festgeschrieben ist. Dies spiegelt sich in absolut paritätischer Finanzierung, aber auch der Haltung nach in einem offenen $G$ espräch auf Augenhöhe wider. Rhetorisch ist die stetige Betonung des Umstands, dass das eigene Rechtssystem Unzulänglichkeiten wie Errungenschaften aufweise und dass man wechselseitig voneinander zu lernen hoffe, ein absolutes Muss. Generell spricht man mehr über sich als über den anderen. Unmittelbarer Widerspruch gegen die $\mathrm{D}$ arstellungen des anderen ist verpönt. Es kommt auf die Z wischentöne an und auf das, was man verklausuliert zwischen den Zeilen dem anderen zu sagen wagt, ohne dass es so deutlich geschieht, dass dieser in seiner Replik darauf eingehen müsste. Eine solche $\mathrm{G}$ esprächsatmosphäre erleichtert es ungemein, auch heikle Themen anzusprechen, ist für viele westliche Besucher aber sehr ungewohnt, weil sie den Eindruck von einer Kombination zweier Monologe erlangen. G erade deutsche Wissenschaftler, die nur sporadisch an der einen oder anderen Rechtsstaatskonferenz teilnehmen und die sonst wenig Kontakt mit China haben, vermissen oft eine gewisse produktive Konfrontativität.

\section{Diversifizierung}

Ein weiteres tragendes Merkmal des Dialogs ist das, was man Diversifizierung nennen könnte. Gerade dadurch, dass man dem Rechtsstaatsdialog zahlreiche andere Aktivitäten einverleibt hat, umfasst er nun die unterschiedlichsten Projekte, die auf allen möglichen Ebenen miteinander kooperieren, von den höchsten staatlichen Stellen bis hin zu rein privaten Initiativen. D as hat zwar auch seine Nachteile, weil eine Abstimmung der verschiedenen Akteure untereinander auf deutscher Seite nur unzureichend funktioniert und zudem manche Akteure eher gegeneinander als miteinander arbeiten. Gerade in Krisensituationen hat sich diese Vielfalt aber sehr bewährt. Nehmen wir zum Beispiel die politische Krise im Herbst 2007, nachdem Bundeskanzlerin Merkel den D alai Lama empfangen hatte. Sie führte zur sofortigen Absage der unmittelbar bevorstehenden Achten Rechtsstaatskonferenz

31 Siehe die „Antwort der Bundesregierung“ - FN 10, Frage 84. 
durch die chinesische Seite, die in München schlicht nicht erschien und nur verlauten ließ, aufgrund technischer Probleme sei die Durchführung der Konferenz leider nicht möglich. Zugleich wurde der Rechtsstaatsdialog insgesamt für einstweilen eingestellt erklärt. In erheblichem Maße betroffen waren natürlich die diplomatischen Beziehungen, und die von Außenminister Steinmeier und seinem Haus unternommenen Klimmzüge, die Beziehung wieder zu kitten, sind durch die Presse hinreichend bekannt geworden. Ebenfalls betroffen war die Rechtsberatung durch die GTZ, allerdings nur kurz und nur auf der höchsten Ebene. Beim D eutschChinesischen Institut für Rechtswissenschaft, das für den Herbst drei internationale Konferenzen geplant hatte, entfiel eine Konferenz zu Corporate Governance, die in Kooperation mit dem Bundesjustizministerium durchgeführt werden sollte. Zwei andere Konferenzen, eine gemeinsam mit dem DAAD (D eutscher Akademischer Austausch Dienst) und die andere gemeinsam mit der Konrad-AdenauerStiftung, fanden dagegen statt, wenngleich die chinesische Seite es sich nicht nehmen ließ, die anwesenden deutschen Diplomaten und die Leitung des DAAD dadurch zu brüskieren, dass sie anstelle des Universitätspräsidenten nur einen „Assistenz-Präsidenten" schickte.

Insgesamt blieb also ein hinreichend starkes Fundament mehr oder weniger unberührt, was es enorm erleichterte, die G esprächsfäden nach Abebben der Entrüstung auf chinesischer Seite wieder aufzunehmen.

\section{Konkretisierung und Kontextualisierung}

Als drittes Merkmal des Dialogs will ich etwas anführen, das mit dem Schlagwort „Kontextualisierung" sicher nur unzureichend umschrieben ist. G emeint ist, dass G egenstand des Rechtsstaatsdialogs etwa nie "die Menschenrechte in China" sind. Erstens würde es schon einmal dem Prinzip der Parität widersprechen, allein auf die Menschenrechtssituation in China abzustellen. Zweitens aber wäre ein Thema "die Menschenrechte" viel zu abstrakt und emotional viel zu sehr aufgeladen, als dass ein fruchtbarer D ialog möglich wäre. Stattdessen wendet sich der Dialog konkreten Sachfragen zu, die jede G esellschaft zu lösen hat. So etwa: „Wie können die Ziele einer effizienten Verwaltungspraxis und der Schutz der Rechte Einzelner miteinander in Einklang gebracht werden?" oder "Wie kann man die Bürger bei Planungsentscheidungen angemessen beteiligen?". All diese Themen haben einen konkreten Menschenrechtsgehalt, der aber von deutschen Kritikern des Dialogs vielfach nicht erkannt wird.

Ich erinnere mich noch gut daran, als unser Institut gemeinsam mit dem Auswärtigen Amt eine der "halboffiziellen“ Rechtsstaatskonferenzen zum Thema „Bürgerbeteiligung bei Infrastrukturvorhaben“ durchführte. Einzelthemen waren u.a. der Rechtsschutz Einzelner gegen rechtswidrige Planungsentscheidungen von Behörden oder die Staatshaftung, im Klartext: Was kann der einzelne Bürger dagegen unternehmen, wenn plötzlich Planierraupen anrollen, sein Wohnviertel niederreißen und ihm eine neue Wohnung in einem Hochhaus am Rand der Stadt zuwei- 
sen, wo er niemanden kennt? Es hagelte in Deutschland Kritik von vielen Seiten, und die Frage, die ich immer wieder zu hören bekam, war: Wieso reden Sie bei der Konferenz nicht über die Menschenrechte? Ich muss sagen: Bei so viel Ignoranz bleibt man wirklich sprachlos - wer den Menschenrechtsgehalt dieser Fragen nicht sieht, der hat sich wohl noch nie G edanken darüber gemacht, was Menschenrechte im täglichen Leben eigentlich bedeuten.

\section{Häufige E inwände}

Abgesehen von Einwänden dieser Art ist der Rechtsstaatsdialog natürlich auch anderen Einwänden ausgesetzt. 32

\section{Unmöglichkeit des Dialogs}

Der erste Einwand ist der der Unmöglichkeit einer effektiven Kommunikation über Rechtsstaatlichkeit wegen eines zu unterschiedlichen rechtskulturellen Vorverständnisses. Die chinesische Auffassung von Rechtsstaatlichkeit, so hört man, sei von der westlichen oder deutschen so sehr verschieden, dass ein Dialog nicht möglich und der Glaube an ihn bestenfalls naiv sei. Was ist daran richtig?

\section{a) D ie E ntwidk lung des R echtsstaatsbegriffes in C hina}

Der chinesische Rechtsstaatsbegriff ist sicher anders entstanden und trägt teilweise andere Züge als der unsere. In jedem Fall ist er älter. Jahrhunderte- und jahrtausendelang war das Problem auf den G egensatz zwischen Herrschaft durch Personen (ren zhi) und Herrschaft durch Gesetze (fa zhi) zugespitzt.33 Die heftige Auseinandersetzung zwischen Konfuzianern und Legisten, welche ihre Hochblüte vor allem vom 7./ 6. bis zum 3. Jahrhundert v. Chr. hatten, erlebte in der Zeit vom 5. bis 3. vorchristlichen Jahrhundert einen Höhepunkt.

D ie Ansicht der Konfuzianer, welche ihre Vorstellungen in die Tradition von Konfuzius (551-479 v. Chr.) stellten, baute auf den Elementen der Hierarchie und Harmonie sowie der Vorstellung vom guten Menschen auf und trat für eine Herrschaft durch moralisch vorbildliche Personen ein. D er Kaiser hat nach konfuzianischer Idee als „Sohn des Himmels" alle Macht inne und ist als einziger zur Rechtsetzung befugt. D iese Tradition und ihre Vorstellung vom ren zhi, also von der Personenherrschaft, sollte im traditionellen chinesischen Rechtsdenken letztlich die O berhand behalten. Zwar kennt dieses vormoderne Rechtsdenken durchaus $\mathrm{Ge}$ -

\footnotetext{
32 Siehe auch L evy, Die deutsche Regierung hat gewechselt - der D eutsch-Chinesische Rechtsstaatsdialog geht weiter, China aktuell 5/ 2006, 64ff.

33 Näheres hierzu s. z.B. H euser, Einführung in die chinesische Rechtskultur (2007), 160ff.; von Senger, Einführung in das chinesische Recht (1994), 16ff.; M oritz, Die Philosophie im alten China (1990), 41ff. und 209ff.
} 
setze (fa), jedoch stehen diese zur vollen Disposition der jeweils Herrschenden, sind im Wesentlichen auf Strafrecht beschränkt und gegenüber überlieferten Verhaltensnormen (li) von untergeordneter Bedeutung.

Die von den Legisten vertretene Gegenansicht wollte das gesamte Staatswesen durch strenge Gesetze ordnen. Der Begriff des fa zhi beinhaltete unserem Verständnis von Rechtsstaat nahe kommende Momente: Kontinuität der Gesetze, Bindung der Exekutive an gesetzlich geregelte Verfahren, öffentliche Zugänglichkeit der G esetze und die rechtliche Regulierung aller wichtiger Bereiche des öffentlichen Lebens. Ein wichtiger Unterschied bestand jedoch darin, dass der Herrscher selbst nicht gebunden sein sollte. Diese Komponente der Bindung der Gesetzgebung an ein differenziertes Rechtssystem wird aus der Perspektive westlicher Juristen als wesentlicher Punkt eines modernen Rechtsstaatsverständnisses gesehen und für den Aufbau eines Rechtsstaates für unerlässlich gehalten. In China wird die Unterscheidung des vormodernen fa zhi und des heutigen Verständnisses des Rechtsstaates vielfach diskutiert. D ie Tendenz auch die obersten Machthaber an die Gesetze zu binden ist nunmehr jedoch nicht mehr zu übersehen: So bedeuten die Änderungen des Art. 5 und des Art. 33 der chinesischen Verfassung von 1982 eine positivrechtliche Festlegung der Überlegenheit des gesetzten Rechts, der Bindung der gesetzgebenden Organe an die Gesetze, und zeigen deutlich, dass die Bedeutung der Menschenrechte in China weiter an Priorität gewinnt. 34

Nach einer relativ kurzen Phase westlich-orientierter und im Zivilrecht stark deutsch beeinflusster $\mathrm{G}$ esetzgebungstätigkeit in der ersten Hälfte des 20. Jahrhunderts, 35 wurde der Gedanke der Personenherrschaft und des Personenkults - wenn auch unter ganz anderen Vorzeichen als zur Zeit der Zhou-Dynastie - unter Mao Zedong wieder absolut dominierend, was durch Maos berühmte Worte "W u fa wu tian“ („Ich bin ohne G esetz und ohne Himmel.") anschaulich belegt wird. Erst in der Ära Deng Xiaoping zeichnete sich eine Wende in Richtung einer modernen Gestaltung eines Rechtssystems ab. Nachdem in der Volksrepublik China die Debatte um den Vorrang von ren zhi oder fa zhi öffentlich geführt wurde und in den Jahren von 1979 bis 1981 einen neuen Höhepunkt erreichte, setzte sich endgültig der Gedanke durch, dass das Staatswesen durch Gesetze zu ordnen sei, denen sich prinzipiell auch die Regierenden unterzuordnen haben. Die negativen Konnotationen, die stets mit G esetzesrecht (fa) im G egensatz zu überlieferten Verhaltensnormen (li) verbunden waren, wurden zunehmend zurückgedrängt und machten einem neuen G esetzesoptimismus Platz.

34 Art. 5 der Verfassung vom 4. D ezember 1982 wurde 1999 ein neuer Abs. 1 vorangestellt: „Die Volksrepublik China praktiziert eine auf Gesetze gestützte Regierung und errichtet einen sozialistischen Rechtsstaat". Näheres zur Verfassungsänderung 1999 bei H eilmann, Änderungen der Verfassung der Volksrepublik China (1999) - Analyse und Dokumentation, abrufbar unter http:/ / www.chinapolitik.de/ china/ pubs/ china_polsys/ polsys3.pdf (Zugriff am 22. Juli 2008). Siehe auch oben unter 2.

35 Siehe dazu unten FN 37. 
Waren die Vorzüge einer Gesetzesherrschaft gegenüber einer Personenherrschaft grundsätzlich festgestellt, blieb damit das Verhältnis zwischen Mensch und Gesetz doch immer noch in vielen Punkten unklar. Für Konfliktstoff sorgte und sorgt vor allem die weitere Frage, inwieweit das Recht instrumentellen Charakter trägt und für die rechtsetzenden Organe des Staates beliebig verfügbar ist. Sehr anschaulich wird dieses Problem anhand der vielen Diskussionen zwischen chinesischen und westlichen Juristen, ob man den chinesischen Rechtsstaatsbegriff fa zhi guo jia („mit Gesetzen den Staat leiten"), wie er auch in der chinesischen Verfassung verankert ist, in englischer Sprache nun als rule of law oder als rule by law übersetzen soll. ${ }^{36}$ Zwischen beiden Ubersetzungen besteht nämlich inhaltlich ein kleiner und sehr feiner Unterschied: Der Begriff rule of law, verstanden im Sinne „Herrschaft des Gesetzes", impliziert eine gewisse Unverfügbarkeit des Rechts und betont individuelle Rechtspositionen des Einzelnen. D as G esetz steht über dem Herrscher, der nicht nach seinem Belieben $G$ esetze erlassen kann.

Der Begriff rule by law, wohl am Treffendsten mit „Herrschaft durch das Gesetz" übersetzt, hingegen reduziert - jedenfalls bei böswilliger Betrachtung durch westliche Juristen - das Recht auf ein opportunes Instrument zur Erreichung politischer oder wirtschaftlicher Ziele.

\section{b) $G$ emeinsame Basis fur einen fruchtbaren D ialog}

Dieser G egensatz des rule of law - rule by law liegt gelegentlich wie ein Schatten über jedem Dialog, der zwischen chinesischen und westlichen Juristen über Fragen der Rechtsstaatlichkeit geführt wird. Er kann den Dialog in meinen Augen aber nur dann wirklich beeinträchtigen, wenn man auf der abstrakten Ebene der Menschenrechte an sich, des Verhältnisses von Staat und Gesetz an sich oder des D emokratiebegriffs einsteigt. Wenn man - wie es der deutsch-chinesische Rechtsstaatsdialog gerade macht - dagegen ganz konkrete Sachprobleme anspricht, dann wird ein tatsächlich oder nur vermeintlich unterschiedliches Rechtsstaatsverständnis auf höchster, abstraktester Ebene immer unwichtiger und tritt immer mehr in den Hintergrund. Es kann jedenfalls den Dialog nicht wesentlich beeinträchtigen.

Nicht zu verkennen ist in diesem Zusammenhang auch, dass sich viele chinesische Gesetze des frühen 20. Jahrhunderts am deutschen Recht orientiert haben, insbesondere im Bereich des Zivilrechts. ${ }^{37}$ Ebenso führte die Rezeption japanischen Rechts, welches oftmals stark an deutsches Recht angelehnt war, zu indirektem Einfluss auf das chinesische Recht. ${ }^{38}$ D iese Entwicklung führte dazu, dass sich

\footnotetext{
${ }^{36}$ Siehe hierzu Ca0, Chinese Law - A language Perspective (2004), 35ff.

37 Der Einfluss des deutschen BG Bs auf das chinesische BGB, welches in den Jahren zwischen 1929 und 1931 schrittweise in Kraft gesetzt wurde, ist unübersehbar. Unter anderem wurde die Unterteilung des G esetzbuches in Pandekten und viele Begriffe des deutschen BGBs übernommen. Siehe u.a. Shao, Die Rezeption deutschen Zivilrechts im alten China, JZ 2 (1999), 80ff. und Mi, Deutsches Recht in China seit der Politik der Reform und Öffnung, ZChinR (2007), 132-139.

38 Siehe Shao, a.a.O., 83.
} 
deutsche Rechtsdogmatik mit chinesischem Rechtsdenken besonders gut verträgt und daher der Rechtsstaatsdialog, welcher auf einer lange währenden Befassung deutscher und chinesischer Juristen mit dem Recht des anderen Landes aufbaut, positiven Einfluss auf beide Rechtsordnungen nehmen kann.

\section{Erfolglosigkeit}

Ein weiterer Einwand, der dem Rechtsstaatsdialog gerne entgegen gebracht wird, ist seine relative Erfolglosigkeit. D enn in der Tat sind wirklich sensationelle Bewegungen auf chinesischer Seite, die klar und eindeutig auf den deutsch-chinesischen Rechtsstaatsdialog zurückzuführen sind, schwer auszumachen.

Eine Forderung nach solchen klaren und sensationellen Erfolgen, welche nicht der Natur des Rechtsstaatsdialogs entsprechen, zu erheben, ist freilich seinerseits naiv. D as chinesische Rechtssystem macht Fortschritte, die man nicht hinwegleugnen kann. So hat die VR China 2004 den Schutz der Menschenrechte und des Privateigentums in seiner Verfassung verankert.39 Im Beamten-, Verwaltungs- oder Patentrecht wurden Strukturen westlichen, insbesondere deutschen Rechts, unmittelbar übernommen. ${ }^{40}$ Todesurteile wurden früher unmittelbar vollstreckt. Ende Oktober 2006 hat der Nationale Volkskongress Maßnahmen beschlossen, um die Verhängung der Todesstrafe einzuschränken, und jedes Todesurteil muss seit 1. Januar 2007 vom O bersten Volksgericht überprüft werden. ${ }^{41}$ Mit dem neuen Sachenrechtsgesetz wurde die Rechtsstellung des Einzelnen im Hinblick auf privates Sacheigentum, insbesondere Wohnungseigentum, deutlich gestärkt. ${ }^{42} 2007$ wurden die Rechte der Strafverteidiger verbessert, die seit 1. Juni diesen Jahres das Recht haben, sich mit ihrem Mandanten nach einer polizeilichen Vernehmung zu treffen, ohne um Erlaubnis bitten zu müssen. ${ }^{43}$ Auch darf die Polizei Gespräche zwischen Verteidiger und Beschuldigtem nicht überwachen, und haben Verteidiger nach der jüngsten Rechtsänderung ein Akteneinsichtsrecht.44 Sie dürfen eigene Beweise vorlegen und haben ein verankertes Recht, Beweisanträge vor G ericht zu stellen.45 Im Mai 2008 traten die Regelungen über die Offenlegung von Regierungsinformatio-

39 Art. 13 der Verfassung von 1982 wurde ebenfalls 2004 ergänzt um den Satz „D as legale Privateigentum der Bürger ist unverletzlich“.

40 Siehe SchulteKulkmann, Der Einfluss westlicher Rechtsberatung auf die Rechtsreformen in der Volksrepublik China, FN 9, 11ff. und die Auflistung der Gesetze, an deren Ausarbeitung die GTZ beratend beteiligt war unter http:/ / www.gtz-law.org/ en/ projects.php (Zugriff am 17. Juli 2008).

41 Mit Beschluss des Ständigen Ausschusses des Nationalen Volkskongresses wurde Art. 13 des „Gesetzes über die Organisation der Volksgerichte“ geändert: „D eath penalty sentences, with the exception of those decided by the Supreme People's Court, shall be submitted to the Supreme People's Court for review and approval." (Übersetzung von "Congressional-Executive Commission on China", siehe www.cecc.gov).

42 Siehe FN 11 und 12.

43 Siehe Art. 33 des am 28. O ktober 2007 geänderten Anwaltsgesetztes der VR China vom 15. Mai 1996.

44 Siehe Art. 33 und 34 leg cit.

45 Siehe Art. 35 leg cit. 
nen in Kraft. D iese Verwaltungsvorschrift stellt einen Paradigmenwechsel dar vom unbeschränkten Aktengeheimnis hin zu einer transparenten Verwaltung. Sie gelten nicht nur für die Behörden der Zentralregierung, sondern auch für die der Provinzverwaltungen. 46

Auch wenn in der Praxis hier noch viele D efizite bestehen mögen, bleibt ein Paradigmenwechsel und bleiben kontinuierliche, kleinere und größere Erfolge doch unverkennbar. G elegentlich, so etwa im Verwaltungsrecht, lässt sich ein unmittelbarer deutscher Einfluss nachweisen, vielfach natürlich nicht. Aber das beweist sicher noch nicht, dass der Rechtsstaatsdialog zu wenige Erfolge zeitige, um das in ihn investierte $\mathrm{G}$ eld zu rechtfertigen.

\section{Feigenblattfunktion}

Schließlich wird dem Rechtsstaatsdialog gerne vorgeworfen, eine Feigenblattfunktion dafür zu erfüllen, dass deutsche Politiker ihre Beziehungen mit China nicht durch die Menschenrechtsfrage belasten müssen und dass die deutsche Wirtschaft guten $\mathrm{G}$ ewissens mit China blühende G eschäfte machen kann. ${ }^{47}$

D ass der Rechtsstaatsdialog auf Politik und Wirtschaft insofern eine entlastende Funktion ausübt, weil er die Rechtsstaatsdebatte in bestimmte, geordnete Bahnen lenkt, ist unverkennbar. Insofern hat diese Beobachtung durchaus einen richtigen Kern. Ich frage mich aber, ob es besonders gut wäre, die Rechtsstaatsdebatte zurückzuholen in Kontexte, die für sie eigentlich ungeeignet sind und die auch und gerade für die weitere Rechtsentwicklung in China verheerende Folgen haben könnte. D enjenigen, die fordern, die Aufrechterhaltung wirtschaftlicher und politischer Beziehungen an größere Fortschritte im Menschenrechtsschutz zu knüpfen, möchte ich warnend entgegen halten, dass der vor 30 Jahren begonnene Prozess der Öffnung gegenüber dem Westen nicht unumkehrbar ist. China hat im Laufe seiner viele Jahrtausende währenden Geschichte schon mehrere drastische Wendungen durchgemacht, und die Beziehungen mit dem Westen insgesamt zu gefährden, indem man die verschiedenen Ebenen des Kontakts miteinander verknüpft und vermengt, könnte sich als verhängnisvoller Fehler herausstellen.

\footnotetext{
46 Am 17. Januar 2007 wurden die „Vorschriften der VR China für die O ffenlegung von Regierungsinformationen" verabschiedet. D eutsche Übersetzung erhältlich bei Münzel, Chinas Recht 2007/ 12, 5.4.07/ 1, unter http:/ / lehrstuhl.jura.uni-goettingen.de/ chinarecht/ inhalt.htm. Näheres siehe A hl, O ffenlegung von Regierungsinformationen in China, ZChinR (2007), 354-358.

47 So zuletzt z.B. die FD P-Politikerin Leutheusser-Scharrenberger und Vertreter von AI in der Frankfurter Allgemeinen Sonntagszeitung vom 29. März 2008.
} 


\section{Bilanz}

Insgesamt möchte ich nach acht Jahren deutsch-chinesischem Rechtsstaatsdialog durchaus eine positive Bilanz ziehen. D as, was ich hier das „Konzept der dritten Spur" genannt habe, der G ewinn an Stabilität durch die Entlastung von Politik und Wirtschaft einerseits und die Einbindung unterschiedlichster Akteure in den Rechtsstaatsdialog andererseits, sowie die Versachlichung der Menschenrechtsund Rechtsstaatsdebatte durch das Herunterbrechen der großen Themen auf konkrete Sachfragen, sind Strategien, die meiner Überzeugung nach richtig sind. Kontinuierliche, kleine Schritte nach vorne sind hundertmal besser als die $\mathrm{G}$ efahr eines großen Schrittes zurück.

\section{Literaturangaben}

Ahl, Björn (2007): Offenlegung von Regierungsinformationen in China. In: ZChinR, 354-358.

Baumann, Xiaoyan (2006): D as neue chinesische Sachenrecht - Seine E ntwidklung unter E influss des deutschen Rechts. Baden-Baden: Nomos.

Cao, D eborah (2004): C hinese L aw - A language Perspective. Aldershot: Ashgate.

D egen/ Liu (2007): RIW Special 1 zu Heft 11.

Heilmann, Sebastian (1999): Ä nderungen der V erfassung der V olksrepublik China A nalyse und Dokumentation. http:/ / chinapolitik/ china/ pubs/ china_polsys/ polsys3.pdf

Heuser, Robert (2007): E infuhrung in die chinesische Rechtsk ultur. Hamburg: Institut für Asienkunde.

Julius/ Rehm (2007): Das chinesische Sachenrecht tritt in Kraft: Revolution oder Viel Lärm um Nichts? In: ZV glRW iss 106, 367-414.

Levy, Katja (2006): Die deutsche Regierung hat gewechselt - der DeutschChinesische Rechtsstaatsdialog geht weiter. In: C hina ak tuell 5/ 2006, 64ff.

Mi, Jian (2007): Deutsches Recht in China seit der Politik der Reform und Öffnung. In: ZChinR, 132-139.

Moritz, Ralf (1990): D ie Philosophie im alten China. Berlin: Deutscher Verlag der Wissenschaften.

Münzel, Frank (2007): Chinas Recht 2007/ 12, 5.4.07/ 1. http:/ / lehrstuhl.jura.unigoettingen.de/ chinarecht/ inhalt.htm.

Ders. (2007): Chinas Recht 2007/4, 16.3.07/1. http:/ / www.mpipriv.de/ shared/ data/ pdf/ sachenrechtsg2007.pdf 
Rau, Johannes (2003): D as Rechtsstaatsprinzip - V oraussetzungen für eine moderne $\mathrm{G}$ esellschaft. Rede von Bundespräsident Johannes Rau in der Universität Nanjing vom 13. September 2003. Erhältlich unter http:/ / www.bundespraesident.de

Rogler, Beate (2005): D eutsch-chinesische Studienprogramme: A nalyse und E mpfehlungen. Beiträge zur Hochschulpolitik 8/ 2005.

Schulte-Kulkmann, Nicole (2002): D er E influss westlicher Rechtsberatung auf die Rechtsreformen in der $\mathrm{V}$ olksrepublik China. Abrufbar unter: http:/ / www.chinapolitik.de/ studien/ china_analysis/ no_13.pdf

von Senger, Harro (1994): E inführung in das chinesische Recht. München: Beck Juristischer Verlag.

Shao, Jiandong (1999): D ie Rezeption deutschen Zivilrechts im alten China. In: JZ 2, 80ff.

Wendehorst, Christiane (2008): Warenverkehr mit der VR China - viel Neues durch das neue Sachenrecht? In: ecolex, 392-395.

Zhou/ Qi/ Lohsse/ Liu (2007): ZC hinR, 68-117. 



\section{Toward Post-Multiculturalism? Changing Communities, Conditions and Contexts of Diversity $^{1}$}

Steven V ertovec

\section{Background and Analysis}

For more than thirty years across a range of countries, numerous policies have had as their overall goal the promotion of tolerance and respect for collective identities, particularly among immigrants and ethnic minorities. Collective called multiculturalism, these policies have been pursued through measures such as supporting community associations and their cultural activities, monitoring diversity in the workplace, encouraging positive images in the media and other public spaces, and modifying public services in order to accommodate culture-based differences of value, language and social practice.

By the early part of the 21st century multiculturalism has been seriously challenged from a number of directions. The changing nature of global migration, new social formations spanning nation-states, and the persistently poor socio-economic standing of immigrant and ethnic minority groups are among the foremost developments that seem to render obsolete aspects of the older models of multiculturalism. In light of and added to these, there has emerged in numerous settings a

1 D er Artikel wurde bereits als Background Paper im U N E SC 0 W olrld Report on cultural diversity veröffentlicht. (Anm. d. Hrsg.) 
broader backlash against multiculturalism in public discourse, policies and public opinion: many critics now see multiculturalism as a foremost contributor to social breakdown, ethnic tension, the demise of the welfare state, failure of public services and the growth of extremism and terrorism.

For all of these reasons there are widespread calls to rethink multiculturalism. This background paper describes such patterns, and discusses the question as to whether we are shifting into a 'post-multiculturalist' world. It also addresses, in passing, several other pertinent questions today including: What are the changing public discourses surrounding multiculturalism? What are the characteristics of new forms of immigration? How have these new forms of immigration impacted on multicultural theories? What are the relationships of immigrants with sending countries? How do all of these patterns contribute to what might be called postmulticulturalism?

Following an initial section outlining some key aspects of conventional multiculturalism and its critiques, the report includes sections describing emergent migration trends leading toward conditions of 'super-diversity,' patterns of diasporic identification and transnationalism, recent public debates that are critical of multiculturalism, and various policy measures taken in response. It concludes by way of speculation regarding the emergence of 'post-multicultural' perspectives which seek to foster both the recognition of diversity and the maintenance of collective national identities.

\section{Multiculturalism}

Looking back historically and considering cases within contexts such as the colonial period, Ottoman Empire and Roman Empire, we can observe that in populations comprised of linguistically, culturally and religiously heterogeneous groups there have always been questions of multi-group governance and the need to negotiate everyday practices and interactions. Just as today, aspects of diversity had to be 'managed' in order to ensure: the non-alienation of specific groups (at least to ensure rule or policy delivery), the limitation of conflict (at least in ways that didn't hurt the dominant group), and the generally smooth functioning of society (or at least the economy). The great 'age of migration' in the latter half of the nineteenth century brought some relatively new issues of diversity management to immigrantreceiving countries, but expectations of 'assimilation' - or the public discarding of social and cultural difference - largely held sway. In the last half of the twentieth century, social, political and public service challenges stemming from yet newer waves of large scale immigration and the settlement of sizable communities prompted many nation-states (and their local government institutions, alongside many business, other public sector and voluntary sector organizations) to adopt policies, structures and programmes designed to manage the emergent new modes of diversity and their accommodation within wider society. 
The paradigm of multiculturalism

Collectively described as multiculturalism, these late 20th century institutional initiatives had a number of broad, common objectives. These included: providing opportunities for group representation to local and national government authorities; restructuring institutions towards pluralistic public service provision; measures to promote equality, respect or tolerance particularly among the dominant population towards minorities; and provision of resources to support the continuity of traditions and identities among immigrant groups (as opposed to assimilation). Further, in many countries multiculturalism differentially entailed actions in the following fields:

- Public 'recognition': support for ethnic minority organizations, facilities, activities; creation of public consultative bodies incorporating such organizations;

- Education: often addressing dress, gender and other issues sensitive to the values of specific ethnic and religious minorities; creation of curricula reflecting the backgrounds of ethnic minority pupils; mother tongue teaching \& language support; the establishment of own schools (publically financed or not);

- Culturally sensitive practices, training and information established within social services, among healthcare providers, police and courts;

- Public materials (such as health promotion campaigns) provided in multiple languages;

- Law: cultural exceptions to laws (such as Sikh turbans instead of motorcycle helmets); oaths on sacred books other than the Bible; recognition of other marriage, divorce and inheritance traditions; protection from discrimination \& incitement to hatred;

- Religious accommodation: permission and support for the establishment of places of worship, cemeteries and funerary rites; allowance of time off work for worship;

- Food: allowance of ritual slaughter; provision of proscribed foods (halal, kosher, vegetarian) in public institutions;

- Broadcasting \& media: monitoring of group images to ensure nondiscrimination or to avoid stereotypes; provision of own media facilities for minority groups. 
To be sure, the policy and programmatic elements of multiculturalism have not been the same in its primary countries of general implementation (particularly Australia, Canada, the United States, Great Britain, Sweden and the Netherlands). Even within the same country, policies relevant to an overall multiculturalist agenda have not taken the same perspectives, aims and approaches. Similarly, public discourse (as found in political debates, media treatment and public opinion polls) has comprised a variety of takes on the topic. Hence, as Stuart Hall (2001: 3) observes,

"Over the years the term 'multiculturalism' has come to reference a diffuse, indeed maddeningly spongy and imprecise, discursive field: a train of false trails and misleading universals. Its references are a wild variety of political strategies. Thus conservative multiculturalism assimilates difference into the customs of the majority. Liberal multiculturalism subordinates difference to the claims of a universal citizenship. Pluralist multiculturalism corrals difference within a communally segmented social order. Commercial multiculturalism exploits and consumes difference in the spectacle of the exotic 'other. Corporate multiculturalism manages difference in the interests of the centre."

Others have pointed to the ideas and programmes surrounding 'radical multiculturalism' or 'polycentric multiculturalism' (Shohat \& Stam 1994), 'insurgent multiculturalism' (Giroux 1994), 'public space multiculturalism' (Vertovec 1996c), 'difference multiculturalism' (Turner 1993) and 'critical multiculturalism' (Turner 1993, Chicago Cultural Studies Group 1994). Similarly G arard D elanty (2003) describes nine kinds of multiculturalism while Steven Vertovec (1998) discusses at least eight different modes or takes on multiculturalism.

The creation and implementation of multicultural policies, structures and programmes have - according to a range of critics within academia, politics and the media - entailed a number of problems. Some commentators have pointed to the ways multiculturalism contributes to the marginalization of minorities by keeping them off 'serious' government policy agendas; others suggest multiculturalism comprises a 'divide-and-rule' strategy by government in relation to ethnic minorities, wrought by ethnic minority associations' competition for funding or political influence. Still others point to the misleading and reifying view of 'communities', as never-changing, socially bounded entities, inherent in multicultural ideology. And there are many who have criticized multiculturalism's over-emphasis on the maintenance of 'culture' at the cost of less policy attention paid to socio-economic inequalities.

D espite these criticisms (and more recent ones, see below), in most places multiculturalism has been successfully 'mainstreamed' in the public sphere such that pluralistic provisions and some acceptance of the need to be culturally sensitive (ridiculed as 'politically correct') have become widespread and commonplace. The following book titles from the 1980s-90s - when multiculturalism, by this name, reached its peak - attest to the variety of public domains reached by the concept: Medical Practice in a Multicultural Society (1988), Counselling and Psychotherapy: 
A Multicultural Perspective (1993), Managing Substance Abuse in a Multicultural Society (1994), Marketing in a Multicultural World (1995), Multiculturalism: Criminal Law (1991), and Multicultural Public Relations (1995). D irectly following and drawing upon this multicultural mainstreaming, by the early 2000s 'diversity management' in the corporate world has become a major function of human resource departments.

\section{The turning of the multicultural tide}

Although since the 1960s there have always been critical views of multiculturalism - seen in various ways as 'pandering' to immigrants and ethnic minorities - by late 1990s/ early 2000s very serious questions arose as to the effectiveness and worth of multicultural policies. These questions stemmed from numerous developments of high public concern.

D espite mainstreaming, the growth of respect and tolerance seemed limited: evidence of the persistence of discrimination and racism was rife, and Europe, Australia, Canada and elsewhere witnessed a seeming rise of right-wing extremism and success among populist, anti-immigrant political parties. Census and other social surveys in numerous countries indicated deep and enduring patterns of inequality among ethnic minorities (by now in their second or third generation after the original immigrants): low educational attainment, high unemployment, poor jobs, low income, bad quality housing, ill health, and little social mobility. In Britain, Germany and elsewhere, reports suggested 'natives' and immigrants/ ethnic minorities were living 'parallel lives' marked by residential segregation, effectively separate schools, different places of worship, divergent community associations, discrete social networks, and disparate places of leisure.

The terrorist actions in America in 2001, Spain in 2004 and Britain in 2005 drew attention to ethnic minority communities as potential harbours for extremists; the fact that the British terrorists were 'home grown' - or born and raised in the UK - made matters worse. By 2005/ 6 the riots in England, France and Australia, alongside the discovery of terrorist cells in the UK, Germany and Canada, suggested to many that not only were many ethnic minorities remaining geographically and socio-economically excluded, but that they posed a significant problem for overall social cohesion, public order and national security.

In many if not all Western countries of immigration, a remarkably common public discourse emerged: there had been a 'failure of integration', and multiculturalism was largely to blame. Surely multicultural policies should have delivered something different? From the political right most of the pre-existing criticisms were re-voiced: multiculturalism keeps ethnic minorities distinct and breaks down common values and national identity. Yet new criticisms began to be heard from the political left: multiculturalism, some said, broke down people's sense of mutual obligations and willingness to contribute to the welfare state. Linking all such discourse was the assumed logic that (a) multiculturalism fosters accentuated or pre- 
served cultural differences; (b) such differences lead to communal separateness; (c) separateness, in turn, entails lack of socio-economic mobility, breakdown of social relations, grounds for conflict and potential for extremism (even terrorism). Also present in such discourse or logic, the blame on multiculturalism also entails blame on immigrants/ ethnic minorities themselves: as the thinking goes, it is their own desire to maintain cultural traditions and distinct identities - a desire that multiculturalism supports - which leads to all these negative consequences. Meanwhile, structural conditions, institutional obstacles or policy failures are rarely being taken into consideration by way of explaining immigrants' and ethnic minorities' poor socio-economic standing.

In these ways across several different national sites, emergent social conditions, prominent events and reactive public discourses have combined to a paint a rather disapproving, if not outright damaging (albeit fairly caricatured) picture of multiculturalism. Added to this important trend, recent patterns of global migration and certain developing practices among migrants themselves also present factors contributing to the need to rethink certain aspects of multiculturalism as well.

\section{Super-diversity}

In the twentieth century, post-war migration primarily comprised substantial numbers moving from one place to another, predominantly by way of specific recruitment or other regulated schemes: for instance, from particular sites in Turkey to Germany, Algeria to France, Chinese to Canada, G reeks to Australia, Mexico to the USA, Pakistan to the UK. Explicit or implicit multicultural policies and structures accordingly arose to engage these kinds of large, increasingly well organized and settled communities. For the most part, these significant, regionally particular immigrant flows decreased in the 1970s.

Today the scene is considerably different. World-wide there has been a rise in migrant (including refugee) numbers over the past two decades: up to some 190 million at present. Furthermore - and significantly - more people are now moving from more places, through more places, to more places.

In comparison to the large immigrant groups representative of the 1950-70s, today newer, smaller, transient, more socially stratified, less organized, and more legally differentiated immigrant groups comprise global migration flows. Such complex social formations have hardly gained attention or a place on the public agenda, which is still largely based on models of previous migration flows. Y et it is the growth of exactly these new variety of migrants that has in recent years radically transformed the social landscape of migrant-receiving countries. The time has come to re-evaluate - in social scientific study as well as policy - the nature of contemporary diversity. With a reworked understanding of new complexities of diversity, the structures and policies meant to deal with diversity - that is, multiculturalism - need to be reworked too. 


\section{The emergence of super-diversity}

In order to better understand and more fully address the complex nature of contemporary, migration-driven diversity, additional variables need to be taken into account by social scientists, policy-makers, practitioners and the public. These include differential immigration statuses and their concomitant entitlements and restrictions of rights, divergent labour market experiences, discrete gender and age profiles characterizing immigrant flows, patterns of spatial distribution in receiving contexts, and mixed local area responses by service providers and residents. The interplay of these factors is what is meant by the notion of 'super-diversity'.

'Super-diversity' is a term intended to underline a level and kind of complexity surpassing anything many migrant-receiving countries have previously experienced. 'Super-diversity' among immigrants is distinguished by a dynamic interplay of variables, including: country of origin (comprising a variety of possible subset traits such as ethnicity, language[s], religious tradition, regional and local identities, cultural values and practices), migration channel (often related to highly gendered flows, specific social networks and particular labour market niches), and legal status (including myriad categories determining a hierarchy of entitlements and restrictions). These variables co-condition integration outcomes along with factors surrounding migrants' human capital (particularly educational background), access to employment (which may or may not be in immigrants' hands), locality (related especially to material conditions, but also to other immigrant and ethnic minority presence), and the usually chequered responses by local authorities, services providers and local residents (which often tend to function by way of assumptions based on previous experiences with migrants and ethnic minorities).

\section{British super-diversity as ex emplar}

The British case, presented below, is not unique to processes, trends and characteristics arising in many immigrant receiving countries.

C ountries of origin. O ne of the most noteworthy features of 'the new migration' is the multiplicity of immigrants' countries of origin. Moreover, most of this new and diverse range of origins relates to places which have no specific historical - particularly, colonial - links with Britain. In London alone there are people from some 179 countries. Many represent just a handful of people, but there are populations numbering over 10,000 respectively from each of no less than 42 countries; there are populations of over 5,000 from a further 12 countries. While pointing to important indicators of diversity, country of origin data itself, however, may mask more significant forms of differentiation than it reveals. Within any particular population from a given country, there will be important distinctions with reference to ethnicity, religious affiliation and practice, regional and local identities in 
places of origin, kinship, clan or tribal affiliation, political parties and movements, and other criteria of collective belonging.

Languages. The growth of multilingualism in the UK has been recognized and engaged in various ways by both social scientists and policymakers, although the latter have often arguably failed to respond in positive or adequate ways. Still, it is now often proclaimed with pride (for instance in the city's successful 2012 Olympic bid) that 300 languages are spoken in London.

Religions. On the whole we can say that among immigrants to Britain, Christianity is the main religion for people born in all continents except Asia; Asia-born people in the UK are more likely to be Muslim than any other religion, although of course Indians include a majority of Hindus and a significant number of Sikhs. For many, religions tend to be broadly equitable with countries of origin - Irish and Jamaicans are mostly Christian, Bangladeshis mostly Muslim and so forth - but even so these categories often miss important variations in devotional traditions within each of the world religions. Taking Islam as example, it is often pointed out that there are several traditions within the faith as practiced by South Asians in the UK (D eobandi, Tablighi, Barelvi, Sufi orders and more). Such variations are multiplied many times when we consider the breadth of origins among Muslims from around the world who now live in Britain (such as Nigerians, Somalis, Bosnians, Afghans, Iraqis and Malaysians). In London Muslims are the most heterogeneous body of believers in terms of ethnicity and country of origin, with the largest group (Bangladeshis) making up only 23.5\%. 'London's Muslim population of 607,083 people is probably the most diverse anywhere in the world, besides Mecca' (The Guardian 21 January 2005).

Migration channels and immigration statuses. Socio-cultural axes of differentiation such as country of origin, ethnicity, language and religion are of course significant in conditioning immigrants' identities, patterns of interaction and - often through social networks determined by such axes - their access to jobs, housing, services and more. However, immigrants' channels of migration and the myriad legal statuses which arise from them are often just as, or even more, crucial to: how people group themselves and where people live, how long they can stay, how much autonomy they have (versus control by an employer, for instance), whether their families can join them, what kind of livelihood they can undertake and maintain, and to what extent they can make use of public services and resources (including schools, health, training, benefits and other 'recourse to public funds'). Therefore such channels and statuses, along with the rights and restrictions attached to them, comprise an additional - indeed, fundamental - dimension of today's patterns and dynamics of super-diversity. 
Coinciding with the increasing influx of immigrants to the UK in the 1990s, there has been an expansion in the number and kind of migration channels and immigration statuses. Each carries quite specific and legally enforceable entitlements, controls, conditions and limitations. Most prominent are the following channels and statuses: work for worship;

- W ork ers - Between 1993 and 2003 the number of foreign workers in the UK rose no less than $62 \%$ to $1,396,000$. This large-scale increase in workers includes people who have come under numerous categories and quota systems;

- Students - The number of foreign students entering the UK recently peaked at 369,000 in 2002 before reducing to 319,000 in 2003. Non-EU students accounted for some $38 \%$ of all full-time higher degree students in 2003;

- Spouses and family members - The number of migrating spouses and family members coming to the UK more than doubled between 1993-2003. Furthermore this is a particularly feminised channel of migration compared with others;

- A sylum-seek ers and Refugees - Throughout the 1990s the number of asylum applications rose considerably in the UK and indeed throughout Europe. Applications (including dependents) in Britain rose from 28,000 in 1993 to a peak of 103,100 in 2002. This too is a highly gendered channel of migration: in 2003 some 69\% were male. The provenance of asylum-seekers represents a broad range: again in 2003 applications were received from persons spanning over 50 nationalities;

- Irregular, illegal or undocumented migrants - This category, variously termed, pertains to people whose presence is marked by clandestine entry, entry by deceit, overstaying or breaking the terms of a visa. In 2005 the Home Office offered a 'best guess' number between 310,000 and 570,000 irregular migrants in the UK;

- $\quad \mathrm{N}$ ew citizens - A great many migrants become full citizens. During the 1990s around 40,000 people became citizens each year. This number has risen dramatically since 2000, with 2004 seeing a record number of 140,795 granted British citizenship.In attempting to understand the nature and dynamics of diversity in Britain, close attention must be paid to the stratified system of rights, opportunities, constraints and partial-to-full memberships that coincide with these and other immigrant categories. 
Moreover - and denoting a key feature of super-diversity - there may be widely differing statuses within groups of the same ethnic or national origin.

These facts underscore the point that simple ethnicity-focused approaches to understanding and engaging various minority 'communities' in Britain, as taken in many models and policies within conventional multiculturalism, is inadequate and often inappropriate for dealing with individual immigrants' needs or understanding their dynamics of inclusion or exclusion.

$\mathrm{G}$ ender. Over the past thirty years, more females than males migrated to the UK; since about 1998, males have come to predominate in new flows. The reason for this may be due to a general shift away from more female oriented family migration to more male dominated work-based migration schemes since 1995. It is likely also related to the inflow of asylum-seekers, most of whom have been male.

A ge. The new immigrant population has a higher concentration of 25-44 year olds and a lower proportion of under-16s than a decade ago, also perhaps reflecting a shift away from family migration. Variance in age structure among various ethnic groups reflects different patterns of fertility and mortality as well as migration. The mean age of new immigrants is 28 - averaging eleven years younger than the mean age of 39 for the British Isles born population.

At both national and local levels, policy-makers and public service practitioners continuously face the task of refashioning their tools in order to be most effective in light of changing circumstances (whether these are socio-economic, budgetary, or set by government strategy). This is equally the case surrounding policies for community cohesion, integration, managed migration and 'managed settlement'. Structures and modes of government support for, and liaison with, ethnic minority organizations have for decades formed the backbone of the British model of multiculturalism. Especially on local levels, these have indeed often provided important forums for sharing experiences and needs, establishing good practices and providing access to services. However, in light of the numerous dimensions of super-diversity, such structures and modes are inadequate for effective representation. Most local authorities have been used to liaising with a limited number of large and well-organized associations; now there are far more numbers in smaller, less (or not at all) organized groups. In any case, just how many groups could such structures support? And how should local authorities account for the internal diversity of various groups, not least in terms of legal status?

Already, existing minority ethnic agencies often cannot respond to the needs of the various newcomers. None of this is to say that community organizations no longer have a place in bridging migrant groups and local authorities or service providers. Such bodies remain crucial to the process, but should be recognized as only partially relevant with regard to their representativeness and scope. 
The growing size and complexity of the immigrant population carries with it a range of significant public service implications. Executives in local authorities around Britain have voiced concerns about the ability of transport systems, schools and health services to manage new needs. Such concerns flag up a substantial shift in strategies across a range of service sectors concerning the assessment of needs, planning, budgeting, commissioning of services, identification of partners for collaboration and gaining a broader appreciation of diverse experiences in order generally to inform debate. Such a shift must begin with gathering basic information on the new diversity.

\section{Transnationalism}

It is now widely recognized among academics and policy-makers alike that transnationalism, or the cross-border and homeland links maintained by migrants, is an inescapable fact of migration under contemporary conditions of globalization. Advanced technologies and lower costs surrounding travel and mobility, telephone calls, internet connectivity and satellite television have meant that dispersed groups can, with relative ease, stay in everyday, close contact with each other or with events in homelands and other diasporic locations. Regular and routine transnational practices of exchange (of people, money, resources and information) and mobilization (for business, religious, social or political purposes) within diasporic networks often ensure that common collective identities are maintained and enhanced. Also, over twenty-five years of multicultural policies in Western, migrantreceiving countries have meant that it has been widely acceptable for immigrants and their descendants to sustain culturally distinct practices and diasporic identities. What are the implications of sustained transnational connections for migrants' integration? There are various answers to this question, various modes of transnationalism and integration that can be examined, and various studies that have attempted to measure or interrogate related processes and phenomena.

Perhaps throughout history, and certainly over the last hundred years or more, immigrants have stayed in contact with families, organizations and communities in their places of origin and elsewhere in the diaspora. In recent years, the extent and degree of transnational engagement has intensified among immigrants, due in large part to changing technologies and reduced telecommunication and travel costs. Enhanced transnationalism is substantially transforming several social, political and economic structures and practices among migrant communities worldwide in both places of migrant origin and reception.

Of course, not all migrants maintain the same level or kinds of transnational engagement, socially, culturally, economically or politically. Much of this will be largely conditioned by a range of factors including migration channel and legal status (e.g. refugees or undocumented persons may find it harder to maintain certain ties abroad), migration and settlement history, community structure and gendered patterns of contact, political circumstances in the homeland, economic means and 
more. That is, transnational practices among immigrants are highly diverse between and within groups (whether defined by country of origin, ethnicity, immigration category or any other criteria), adding yet another significant layer of superdiversity to all those outlined above.

Many migrants develop and maintain strong modes of community cohesion but not necessarily with others in their locality of settlement. The strongest senses of cohesion or belonging may remain with others in a homeland or elsewhere. However, this needn't mean they are not becoming integrated in their new setting. Belonging, loyalty and sense of attachment are not parts of a zero - sum game based on a single place. That is, the 'more transnational' a person is does not automatically mean the 'less integrated' he or she is, and the 'less integrated' one is does not necessarily prompt or strengthen 'more transnational' patterns of association.

Empirical research has demonstrated the complex relationships between modes of transnationalism and integration. Numerous findings, analyzed and published by a variety of academics, demonstrate that across a range of variables and correlations, modes of transnational participation have complex and generally positive interplays with processes of integration.

The incontestable fact is that with regard to either processes of transnationalism or integration, migrants adapt. Sustained and intensive patterns of transnational communication, affiliation and exchanges can profoundly affect manners of migrant adaptation - including practices associated with positive or limited integration - through the maintenance of a particularly strong sense of connection or orientation to the people, places and senses of belonging associated with the place of origin. Such increasing incidence among contemporary migrants (afforded especially by cheap telephone calls and transportation) arguably contributes to a more widespread process of transformation affecting many Western societies, namely the public recognition of multiple identities. As in earlier eras, migrants feel powerfully bound to homelands and communities elsewhere - and now they can variously express and enhance this attachment. At the same time, new immigrants clearly are getting on with developing a new life, livelihood, social ties and political interests in their places of settlement.

Quite clearly, in the security-gripped era since 9/11 diasporic identities and transnational relations have come to be regarded by many with suspicion. There have been growing fears of ideological fifth columns, terrorist sleeper-cells, and other enemies within. And regardless of the social scientific findings that migrant transnationalism does not impede integration, politicians and the wider public perceive that the maintenance of ties with homelands means that migrants and ethnic minorities have not - and do not want to - become part of their societies of settlement. Such a view, combined with the anti-multiculturalism trends and the new challenges broad about by immigrant super-diversity, have arguably propelled into an era of post-multiculturalism. 


\section{Post-Multiculturalism}

As we have seen, for a variety of reasons multiculturalism has come to be seen by many as a concept or set of policies that legitimized a retreat into culturally and physically separate minority communities. It has become associated with socially disintegrative effects. It has been perceived as supporting an assumed unwillingness of migrants to integrate. In response to these issues and as a kind of corrective set of measures, policies to foster 'community cohesion', stronger national identity and mandatory immigrant integration are being rolled out in countries around the world.

In places such as France, G ermany, the United Kingdom, the Netherlands, Singapore and Australia, the government has established policies and programmes implementing citizenship courses and tests for immigrants. These require the acquisition of knowledge of national civics, dominant cultural norms and values. Eligible immigrants who pass these courses and tests are rewarded with citizenship ceremonies, which themselves are meant to symbolically serve as emblems of national belonging.

Increasing language requirements for immigrants are being rolled out in many places too. Newcomers must demonstrate acceptable standards or levels of competency in the official language, again through compulsory courses and tests - sometimes even prior to entry. Failure to engage or pass such language requirements is being met by a variety of penalties.

In these ways and more, the onus and obligation is being placed on immigrants and ethnic minorities to take up 'host' country values and cultural practices and to actively demonstrate their desire to 'belong'. Such measures are seen by policymakers as crucial steps to ensure immigrants' and ethnic minorities' own socioeconomic mobility, to avoid unrest and to guarantee security of all.

These measures comprise key elements of what might be called postmulticulturalism. But this does not simply mean the return to 'assimilation' (at least as it was practiced in the first half of the twentieth century). That is, despite a strong emphasis on conformity, cohesion, national identity and dominant cultural values, in practically all the contexts in which such new policies are being implemented there remains importantly voiced and institutionally embedded an acceptance of the significance and value of diversity. In this way post-multiculturalist policies and discourse seek 'to have it both ways': strong common identity and values coupled with the recognition of cultural differences.

As D esmond King (2005: 122) has described it in the USA,

Modern American nationhood is an ideology of 'post-multiculturalism': a wide acknowledgment of group distinctions combined with a state struggle to ensure that government policies do not accentuate hierarchical divisions between groups based on race, ethnicity and national background... It is post- in that the demands commonly advanced under a multiculturalist agenda are now quite modest ones. 
Accordingly, governments in several countries are currently challenged by a search for post-multiculturalist models that somehow fuse agendas of the left ('celebrating' diversity, fostering social capital, reducing socio-economic inequality) and the right (promoting national identity, marginalizing or eliminating competing values, limiting new immigration as a presumed inherently divisive process). As King (2005: 123) puts it, the challenge is to construct a state ideology, structures and programmes that are 'broad enough to permit strong group identities to endure within a legal framework upholding the rights and obligations of citizenship.'

Once more, the United Kingdom can serve as example of post-multiculturalist policies. Recent policy documents such as Improving Opportunity, Strengthening Society (issued by the Home O ffice in 2005) shows that the government is seeking simultaneously to be devoted to: improving life chances and reduce inequalities among ethnic minorities (regarding education, jobs, health, housing and policing), promoting 'a cohesive society' by bolstering a sense of common belonging and participation in civil society, and fostering a greater understanding of the 'range of cultures that contribute to our strength as a country.' It seeks to better integrate immigrants through: citizenship in school curricula, classes for immigrants on British history, customs and public services, a stress on English language acquisition, citizenship tests, ceremonies for new citizens and the possible celebration of a Citizenship D ay.

\section{Conclusion}

In diverse contexts around the world where some form of multiculturalism obtained over the past two or three decades, there are observers who put the blame for a supposed 'failure of integration' directly on multicultural policies and ethnic minorities' persistent cultural practices and homeland orientations. They argue that too much cultural preservation and too many maintained links to places of origin are responsible for the poor conditions surrounding immigrants and their descendents. They suggest that the size and diversity of current migration patterns is leading to further social breakdown, particularly if supported by multicultural policies. However multiculturalism has never been comprised of a single type or piece of policy, institutional framework or programme. Moreover, most multicultural policies were not intended to produce economic outcomes, nor a sense of separateness among minority communities, but rather a broad social acceptance and recognized inclusion in dominant public spheres.

Migration and cultural diversity will certainly remain high on the public agenda for many years to come. Meanwhile patterns and processes of global migration are creating ever more contexts of 'super-diversity', and migrants are maintaining strong diasporic identities and direct transnational ties with their homelands. The need for explicit policies and structures to engage these issues is acute. If multiculturalism has been damaged, surely something else must replace it. 
Recent 'post-multicultural' agendas certainly do not mean that multiculturalism is 'dead'. Just the world, or '-ism', seems to be. No politician - except perhaps in Canada, where multiculturalism still enjoys prominence as part of the national identity - wants to be associated with 'the M-word'. The gains of decades of multiculturalism, particularly a broad, everyday (or institutionally mainstreamed) acknowledgement of the gains and value of ethnic diversity, are still evident. This is to be seen in, among other sites, schools, organizations and workplaces. Further, in many places and despite anti-multicultural rhetoric, public opinion polls still tend to show high levels of respect for diversity. For instance, Eurobarometer recently demonstrated that 'Almost three-quarters of EU citizens believe that people with a different background (ethnic, religious or national) enrich the cultural life of their country' (European Commission 2007: 4).

It can be said that the turn from explicit 'multicultural' discourse and policies has largely been based on a misreading of their purposes and effects. Nevertheless, the measures put in their place need not mean an emphasis on assimilation, intolerance and a resurgence of jingoistic nationalism. Social cohesion and national identity can coexist with a valuing of diversity in the public sphere, programmes to recognize and support cultural traditions, and institutional structures to provide ethnic minority community representation - all without reference to 'the M-word'. In this way it is hoped that whatever a 'post-multicultural' condition looks like, it might still entail the fashioning a greater sense of cosmopolitanism, respect for others, and social justice for migrants and their descendants.

\section{Case Studies/ best practices}

The following represent a variety of cases intended to show highly diverse practices and programmes that positively promote cultural diversity across a range of sectors. Descriptions are drawn from websites, media reports and information provided by local observers (including Ricard Zapata, Nancy Foner, D an Hiebert, Susanne Wessendorf, Ayse Caglar and G ergo Pulay).

\section{Network of Public Libraries, Catalonia, Spain}

Catalonia's D epartment of Culture and Media has supported a variety of measures to establish social integration programmes within the region's 330 public libraries. In addition to the acquisition of 7,228 documents in 2006-2007 - mainly in Punjabi, Portuguese, Russian, Urdu, Arabic, G erman and English - the Library Service has also implemented the 'D iaris del Món' (World Press) programme, a service that offers through satellite technology over 180 newspapers from sixty different countries in twenty languages. 
Libraries in the network have specialised collections, press and activities on cultural diversity. They also offer: a Welcome service for migrants (electronic information guides on administrative and legal procedures, health care, social assistance, useful addresses and private associations in Catalonia); Tales from other countries (told in Catalan or bilingually); Exhibitions (on migrants coming to Catalonia from all over the world); Easy reading clubs (to improve knowledge of Catalan); School visits (especially for recently arrived pupils to introduce the library and its services in order to facilitate their integration); and special Projects (such as 'Youth Area' intended to create a cultural meeting point within the library, specifically devoted to them 'Trapeze' aimed at integrating young Arabs, and 'Bibsons', a live radio programme from the library aiming to foster the relation between migrant and nonmigrant youth).

\section{Radio Multikulti, Berlin, Germany}

Radio Multikulti was established in 1994 as an experiment to provide information about the cultural diversity of everyday Berlin. The radio station's strategy involves providing 'information' in two senses: one is to convey basic information about the various groups and cultural backgrounds now found in the city in order to fashion a general climate of acceptance and integration; another is to supply practical assistance to the public - often specifically immigrants and ethnic minorities - by way of information on developments concerning legal conditions and social programs. Alongside news and public information, the station produces diverse forms of entertainment. The total effect is to foster different understandings of cosmopolitanism, directed at both $\mathrm{G}$ erman and 'non-G ermans' in Berlin.

The daily structure of programming reflects other important aspects of Radio Multikulti's strategy. This includes: reports on developments in world politics, European news, and events in Berlin and elsewhere in Germany; 'World music'; interviews with guests from a range of backgrounds to discuss and criticize new activities and initiatives surrounding cultural diversity; and for five hours each day, a succession of programs in 'the languages of the world-city': Turkish, Albanian, Arabic, Kurdish, Persian, Polish, Russian, Vietnamese, Italian, Spanish, G reek and separate programs for Serbs, Croats, Slovenians, Bosnians and Macedonians.

Radio Multikulti has received numerous awards for promoting diversity issues, such as the CIVIS prize from the Federal Commissioner for Foreigners' Affairs, UNESCO recognition as the German partner for the World Decade for Cultural D evelopment, and Internationale Medienhilfe's radio station of the year.

\section{Collingwood Neighbourhood House, Vancouver, Canada}

Part community centre, part settlement house for immigrants, part recreation club, Collingwood Neighbourhood House (CNH) began twenty years ago as a local community initiative serving the Renfrew-Collingwood area of eastern Vancouver. 
As an area of considerable socio-economic deprivation (some 30\% living in 'conditions of poverty'), the Renfrew-Collingwood is home to $50 \%$ Chinese residents, 9\% Filipino, 8\% South Asian and the rest a mix of other ethnic origins. CNH presents a single facility for a wide range of integrative functions for the entire neighbourhood.

It provides educational, cultural, recreational, and social programs in addition to child care programs, day camps, and a Family Place with activities for preschoolers and social time for caregivers. Settlement services for new immigrants include English language classes for adults (child care provided for some classes), Chinese and Korean settlement workers and information in English, Hindi, Punjabi, Cantonese, Spanish and Tagalog. Services for seniors include information and referral, social activities, and fitness programs. Youth services include the Buddy Program which matches elementary school age newcomers to Canada with peer hosts. Also provides proposal writing, event promotion, and conflict management training to increase community leadership skills. Offers various recreation and sport activities and computer training.

$\mathrm{CNH}$ was the subject of the documentary film Where Strangers Become Neighbours: The Story of Collingwood Neighbourhood House and the Integration of Immigrants in Vancouver', which has been popular at several film festivals and which won first prize in BMW G roup's prestigious Intercultural Learning Awards.

\section{Multicultural Center, Prague, Czech Republic}

Founded in 1999, the Center presents a remarkable range of educational, cultural and information initiatives. These include workshops, courses, international seminars, debates, film screenings and book readings for children, students, teachers and librarians. Its overall aims are to promote a tolerant society in the Czech Republic while promoting the values of social integration and cohesion.

Examples of the Center's programmes include: the Dialogue of Cultures (focusing on the interaction and blending of different cultures, languages and religions in the Czech Republic through film screenings, readings, exhibitions, a multicultural afternoon for children and soup competitions), Women between Cultures (a series of debates focusing on the position and role of women in different cultures), and Readings about Minorities and for Minorities (presenting poetry and prose of minorities living in the Czech Republic and elsewhere). Its educational projects entail diversity management (courses designed for company management and teams working in intercultural environment), programs for teachers, pedagogues and librarians, and intercultural workshops for children and students.

Since 2002, the Center has uniquely implemented D iversity in Libraries, a project designed for Czech public libraries and aimed at turning them into a unique space where diverse cultures can meet. It has also distributed, free of charge, a number of books for children, students, experts as well as the general reading public to 500 libraries all over the Czech Republic. In 2004 the Centre carried out a 
survey among 500 libraries in order to find out how Czech libraries work with minorities and foreigners and what services are available to these new users. Stemming from this, it has also initiated the project Libraries as gateways to the integration of immigrants in the EU.

\section{The Media Diversity Institute, London, United Kingdom}

The Media D iversity Institute (MDI) is a charity devoted to enhancing the role of media to lessen inter-group conflict, advance human rights - especially minority rights - and to support deeper public understanding of all types of social diversity. It focuses on regions where news media have previously played a destructive role in exacerbating ethnic and religious conflicts and violations of human and minority rights, such as in Serbia, Israel, Nigeria and Rwanda.

MD I works with media organisations, journalists, journalism educators, NG Os and governments to prevent and reconcile conflict, promote tolerance of vulnerable groups, and stimulate balanced and non-partisan journalism. It develops and employs a range of tools, training methods and practical reporting initiatives to that end. MD I works with local organizations comprising the Reporting Diversity Network. Together they provide local cross-ethnic reporting projects, media training for minority NGO groups, and special curricula on reporting diversity for journalism schools.

Examples of MDI's work include: work in Bosnia with the Sarajevo Media Center to develop a soap opera that will promote understanding and acceptance of 'others'; collaboration with the Beta News Agency in Serbia to produce and distribute more than 70 Reporting Diversity-based articles by 15 correspondents based throughout southeastern Europe while persuading the Ministry for Ethnic and National Minorities to support a special Web site dedicated to minority issues; and assisting in the development of Reporting Diversity courses within journalism faculties and schools at Zagreb University; Tirana University, Sarajevo University, Sofia University, Bucharest University, and the Novi Sad School of Journalism, Serbia.

\section{International Gardens, Dietzenbach, G ermany}

International $\mathrm{G}$ ardens Dietzenbach is one of almost 100 gardening projects under the patronage of the Stiftung Interkultur (Foundation Interculture). Following the example of 'International Gardens Göttingen', in many G erman Cities intercultural gardening projects were initiated. However, the organisation of each gardening project is undertaken by the members, who are mainly families with a migratory background alongside $\mathrm{G}$ erman families.

The objectives of the gardening project are: to foster the integration and participation of families with a migratory background in the city's life; to establish and improve $\mathrm{G}$ erman as the language of communication (also directly through offering 
German language courses); and to support the independency of migrants themselves. Of particular note, the scheme offers female Muslims with a migratory background access to so-called semi-public spaces.

In addition to its integrative function, the project makes use of the idea of using the idle space for gardening. Involved families from D ietzenbach come from seven different countries of origin (Afghanistan, Morocco, Pakistan, Poland, the Czech Republic, Turkey and Germany). Together they have planted vegetables, trees and bushes while they have also built tool sheds, playgrounds and other facilities. Future plans include the establishment of a community house, while fruit trees have been donated so that an orchard can be planted.

\section{France Télévisions, Paris, France}

Since 2004 France Télévision has implemented an Affirmative Action Plan for Integration (Plan d'Action Positive pour l'Intégration or PAPI). This programme entails measures to improve the presence, representation and promotion of cultural diversity within the organisation. It also provides a unit with representatives from all television genres and ensures both the presence and positive representation of cultural diversity on programmes, at the level of programme participants (e.g. presenters, chroniclers and hosts) as well as at the level of the choice of the programmes broadcast. Regular studies, meetings and seminars are held to stimulate reflections regarding the necessity to take into account France's diversity.

Further, following the crisis in certain districts of Paris in November 2005, members of France Télévisions reflected on the gap between the way in which diversity was conentially portrayed in fictional programmes and in the news on French television channels and the way in which it was being perceived in 'sensitive' neighbourhoods. Subsequently France Télévisions set up two regular activities: Citizenship-Media Forums in which journalists meet with college and school students from the 'priority educational zones' (zone d'éducations prioritaires or ZEP), to discuss and exchange views on their news reports; and Diversity Fiction Screenings when TV films about underprivileged districts are shown and the team involved talk with local inhabitants about the film in question.

France Télévisions has also led many European initiatives and debates about the presentation of diversity in public programming.

Fondation ECAP, Institute for Vocational Training, Continuing Education and Research Zürich, Switzerland

Significantly founded in 1984 as a 'bottom-up' initiative by Italian migrants themselves, ECAP's Institute for Vocational Training, Continuing Education and Research has been opened up to all new migrants. The institute provides: general education, language and occupational training for foreign workers living in Switzerland; training of adult education instructors as well as language and cultural media- 
tors; research on the need for education and on the social effects of education; planning, implementation and evaluation of new educational models; organization of conferences and student seminars; and publication of research, essays and didactic materials.

The institute's training programs are accessible in fourteen cantons around Switzerland. It is comprised of over four hundred employees. Funded by a variety of sources (Swiss public institutions, institutions from migrants' countries of origin, course fees and sale of books), ECAP works closely with: Swiss institutions at federal and cantonal levels; migrants' countries of origin and their representations in Switzerland; migration organizations; trade unions; and numerous public and private companies.

\section{Immigrant History Week, New York City, United States}

Established by Mayor Bloomberg in 2004, Immigrant History Week is comprised of numerous functions meant to foster communication, understanding and respect among all inhabitants of New York City. Its stated goals are 'to create an environment of inclusiveness that embraces and celebrates all New Yorkers', 'to celebrate New Yorkers' immigrant histories and contributions', 'to connect New Yorkers of different origins', and 'to inspire New Yorkers to reclaim and take pride in their immigrant roots and history'.

The weeklong cultural celebration features more than 50 free or low-cost events throughout the city's five boroughs. The events include family programs, cultural celebrations and multi-day workshops hosted by community organizations, museums, public libraries and CUNY. The Mayor's Office for Immigrant Affairs issues a call for projects and events for Immigrant History Week, to which organization can submit proposals for dance or music performances, panel discussions, art and photo exhibitions and workshops. Venues include libraries, museums, community centers and other public spaces. Examples of events are: 'Many Hands, Many Places', an exhibit featuring the works crafted by immigrant artisans; 'Silent Film Series: Hungry Hearts and The Immigrant', a recently restored dramatic film based on the short stories of a Polish immigrant; and 'The Immigrant Experience - Crossing the Boulevard', a multi-media performance that traces the lives of recent immigrants to Q ueens.

As part of Immigrant History Week, the Mayor's Office of Immigrant Affairs also has launched a comprehensive guide of community based organizations that provide services for New York City's immigrants. The guide gives information about the types of services available in the five boroughs and languages spoken at the provider locations. For example, guide describes adult literacy programs, immigration and legal services, and health and nutrition counseling. It also contains information in English, Spanish, Chinese and Russian about key City laws and policies that affect immigrants. 
During Immigrant History Week the Mayor also give awards to individuals and groups for their work in immigrant communities.

\section{Athe Sam Roma Festival, Budapest, Hungary}

The A the Sam Roma festival took place in Budapest in June 2007. It brought several well-known Roma artists and performers together with a mixed audience of Roma and non-Roma Hungarians. Roma music entailed a broad spectrum of genres ranging from the traditional to rap, jazz and classical music. There were also theater performances, including a 'self-ironic display' about 'the Roma life', filmscreenings, and exhibitions. Although there were roundtables about 'Roma in the educational system', or 'Roma in the media', it was the music and performances, which were central to the festival program and to its success.

The festival was not framed within the usual terminology of politics related to Roma in Hungary - such as poverty, discrimination, exclusion and citizenship rights - but as a cultural festival of high-quality music and arts which brought different Roma groups and non-Roma together. The relations among the organizers, performers (which also included artists from Brazil and Spain) and the audience were mediated through arts, not in the terms of ethnic majority/ minority. D espite the exclusionary divisions between these groups in the daily life, at the festival, they were artists and a public who came together through art and culture.

Instead of aiming to preserve the existing divisions, i.e. bringing Roma and non-Roma Hungarians' 'own' music and art into the encounter (as it is the case in most multicultural events), it was built on crossbreeding of cultural forms and genres. Such events have the potential to foster cultural diversity as a sustainable diversity without leading to ethnic and/ or cultural closures. If cultural diversity is a project of democratic inclusion which will create a more inclusive public space for communication and exchange and enable the access of the excluded to this public space by changing the terms of participation, then the 'Athe Sam Roma festival' was such a good practice.

\section{Some recommendations}

1) While pointing to important indicators of diversity, country of origin data may mask significant forms of differentiation. Within any particular population from a given country, there will be important distinctions with reference to ethnicity, religious affiliation and practice, regional and local identities in places of origin, class and social status, kinship, clan or tribal affiliation, political parties and movements, and other criteria of collective belonging. Surveys, policies and reports should take greater account of a range of variables when describing migrant or ethnic minority populations. 
2) Immigrants' channels of migration and the myriad legal statuses which arise from them are often just as, or even more, crucial than shared ethnicity or country of origin with reference to: how people group themselves and where people live, how long they can stay, how much autonomy they have (versus control by an employer, for instance), whether their families can join them, what kind of livelihood they can undertake and maintain, and to what extent they can make use of public services and resources (including schools, health, training, benefits and other 'recourse to public funds'). Immigration status is not just a crucial factor in determining an individual's relation to the state, its resources and legal system, the labour market and other structures; it is an important catalyst in the formation of social capital and a potential barrier to the formation of cross-cutting socio-economic and ethnic ties. Legal status should be recognized more as a key variable of social differentiation.

3) It is increasingly recognized that migrants engage in a variety of transnational practices such as sending remittances. However, not all migrants maintain the same level or kinds of transnational engagement, socially, culturally, economically or politically. Much of this will be largely conditioned by a range of factors including migration channel and legal status (e.g. refugees or undocumented persons may find it harder to maintain certain ties abroad), migration and settlement history, community structure and gendered patterns of contact, political circumstances in the homeland, economic means and more. Hence, transnational practices among immigrants in Britain are highly diverse between and within groups (whether defined by country of origin, ethnicity, immigration category or any other criteria). Policy-makers should pay greater attention to such differentiation.

4) Belonging, loyalty and sense of attachment are not parts of a zero-sum game based on a single nation-state or society. That is, the 'more transnational' a person is does not automatically mean the 'less integrated' they are, and the 'less integrated' does not necessarily prompt or strengthen the 'more transnational' patterns of association. While migrants continue to feel powerfully bound to homelands and communities elsewhere, they are now more able to maintain and enhance these feelings while at the same time are quite capable of developing a new life, livelihood, social ties and political interests in their places of settlement. Politicians, policy-shapers, the media and other public actors should take these facts into account.

5) It is often clear in various studies that group inter-relations are closely dependent on the existence or absence of competition for local resources and services (whether of state, voluntary or public sector). Lack of conflict between ethnic groups is often due to a separation of communities by way of economic niches, and or differential demands on pubic resources. Policy- 
makers should reflect on whether their measures might actually make matters worse for minorities by creating conditions of competition.

6) In order to be successful as a strategy for breaking down prejudices and encouraging interaction, individuals should be made aware of each others' multiple category memberships under conditions that promote inclusiveness. People should be able to represent themselves by way of voicing their many identities, not simply a presumed 'ethnic' one.

7) Given the overwhelming fact that most new migrants move into places populated by previous cohorts of immigrants or ethnic minorities, a wide variety of interactions and integration processes occur among these groups - not just with regard to longstanding White communities. Indeed, many immigrants often only meet, live in the same building with, socialize or work with other immigrants or British ethnic minorities. These kinds of encounters and processes have hardly been addressed in social scientific research or policy development. Support should be given to previous migrant and ethnic minority groups in terms of assistance in integrating newcomers.

8) Structures and modes of government support for, and liaison with, ethnic minority organizations have for decades formed the core of models of multiculturalism. Especially on local levels, these have indeed often provided important forums for sharing experiences and needs, establishing good practices and providing access to services. However, in light of the numerous dimensions of contemporary super-diversity, such structures and modes are inadequate for effective representation. Most local authorities have been used to liaising with a limited number of large and well-organized associations; now there are far more numbers in smaller, less (or not at all) organized groups. Now given new numbers and complexities of migration, just how many groups could such structures support? Existing minority ethnic agencies often cannot respond to the needs of the various newcomers. None of this is to say that community organizations no longer have a place in bridging migrant groups and local authorities or service providers. Such bodies remain crucial to the process, but should be recognized as only partially relevant with regard to their representativeness and scope.

9) The growing complexity of the population carries with it a range of significant public service implications. Among these is no less than a fundamental shift in strategies across a range of service sectors concerning the assessment of needs, planning, budgeting, commissioning of services, identification of partners for collaboration and gaining a broader appreciation of diverse experiences in order generally to inform debate. Such a shift must begin with gathering basic information on the new diversity. Existing measures are inade- 
quate and may even impair service delivery. Moreover, no simple 'knowledge based' training - in which service providers are taught the customs and values of particular ethnic minority cultures - can prepare professionals for all the issues that ever increasing diversity creates. Learning generic skills to respond flexibly to a wide range of cultural encounters is more appropriate.

10) In order to avoid the conventional trap of addressing newcomers just in terms of some presumably fixed ethnic identity, an awareness of the new superdiversity suggests that policy-makers and practitioners should take account of new immigrants' plurality of affiliations (recognizing multiple identifications and axes of differentiation, only some of which concern ethnicity). Recognition of the range of affiliations and engagements - such as with their localities of residence - will likely demonstrate that ethnic minorities are far better 'integrated' than is often presumed.

\section{Literaturangaben}

Ager, D. E. (1996): L anguage Policy in Britain and F rance. London: Cassell.

Alba, R. and V. Nee (1997): 'Rethinking assimilation theory for a new era of immigration'. International M igration R eview 31(4), 826-74.

Alibhai-Brown, Y. (2000a): A fter M ulticulturalism. London: Foreign Policy Centre.

- (2000b): W ho D o W e Think We A re?: Imagining the N ew Britain. London: Allen Lane.

- (2004): 'Beyond Multiculturalism'. D iversité C anadienne 3, 51-54.

Allam, K. F., M. Martiniello, and A. Tosolini (2004): L a citta' M ulticulturale. Identità, D iversità, Pluralità. Bologna: EMI.

Allemann-Ghionda, C. (1998): M ultikultur und Bildung in E uropa. Bern, New York: Peter Lang.

Ålund, A. and C. Schierup (1991): Paradoxes of Multiculturalism: E ssays on Swedish Society. Aldershot: Avebury.

Amin, A. (2002): 'Ethnicity and the multicultural city: Living with diversity'. E nvironment and Planning A 34, 959-80.

Amit-Talai, V. (1995a): 'Anthropology, multiculturalism and the concept of culture'. Folk 37, 135-44.

Anthias, F. and N. Yuval-D avis (1993): Racialized Boundaries: Raœ, N ation, G ender, $\mathrm{C}$ olour and Class and the A nti-Racist Struggle. London: Routledge. 
Asad, T. (1990): 'Multiculturalism and British identity in the wake of the Rushdie Affair', Politics and Society 18, 455-480.

Bach, R. (1993): Changing Relations: Newomers and Established Residents in U.S. Communities. New Y ork: Ford Foundation.

Back, L. (1996): N ew E thnicities and Urban Culture: Racisms and Multialture in Y oung L ives. London: UCL Press.

Bade, K. J. (2000): Migration und Integration in D eutschland seit dem Z weiten W eltk rieg: Probleme, E rfolge, Perspek tiven. Hannover: Niedersächsische Landeszentrale für politische Bildung.

Bader, V. (1999): 'Religious Pluralism. Secularism or Priority for D emocracy?'. Political Theory 22, 597-633.

- (2003): 'D emocratic Institutional Pluralism and Cultural Diversity'. In: D. Juteau and C. Harzig (eds): The Social Construction of D iversity. Oxford, New York: Berghahn, 131-67.

Banks, S.P. (1995): M ulticultural Public Relations. London: Sage.

Banting, K. and W. Kymlicka (eds) (2006): Multiculturalism and the W elfare State. Oxford: Oxford University Press.

Basch, L., N. G lick-Schiller and C. Szanton-Blanc (1993): N ations Unbound: Transnational Projects, Postolonial Predicaments, and D eterritorialized N ation-States. New York: Routledge.

Bauböck, R. (1992): Immigration and the Boundaries of Citizenship. Coventry: Centre for Research in Ethnic Relations. Monographs in Ethnic Relations No. 4.

- - (1994a): The Integration of Immigrants. Strasbourg: Council of Europe. CD M G (94) 25E.

- - (1994b): (Ed.) From A liens to Citizens: Redefining the Status of Immigrants in E urope. Aldershot: Avebury.

- - (1995): Transnational Citizenship: Membership and Rights in International Migration. Aldershot: Elgar.

- (2002): Farewell to Multiculturalism? Sharing Values and Identities in Societies of Immigration. Journal of International Migration and Integration 3, 1-16.

- (2003): 'Public Culture in Societies of Immigration'. In: R. Sackmann, T. Faist, and B. Peters (eds): Identity and Integration. Migrants in W estern E urope. Ashgate: Avebury, 37-57.

- (2004): 'Multiculturalism'. In: A. Harrington, B. Marshall, and H.-P. Müller (eds): R outledge E ncyclopedia of Social Theory. New Y ork, London: Routledge. 
Bauböck, R., A. Heller, and A. R. Zolberg (1996): The Challenge of D iversity: Integration and Pluralism in Societies of Immigration. Aldershot: Avebury.

Bauböck, R., and J. F. Rundell (eds) (1998): Blurred Boundaries: Migration, E thniaty, Citizenship. Aldershot: Ashgate.

Baumann, G. (1996): Contesting C ulture: D isoourses of Identity in Multi-E thnic L ondon. Cambridge: Cambridge University Press.

- (1999): The M ulticultural Riddle: Rethinking N ational, E thnic, and Religious Identities. New York, London: Routledge.

Bennett, D . (ed) (1998): M ulticultural States. Rethinking D ifference and Identity. London, New York: Routledge.

Blommaert, J., and J. Verschueren (1998): D ebating D iversity: A nalysing the D iscourse of Toleranœ. London: Routledge.

Brubaker, R. (1989): Immigration and the Politics of Citizenship in E urope and $\quad \mathrm{N}$ orth A merica. Lanham, Md, London: University Press of America.

- (2001): The Return of Assimilation? Changing Perspectives in France and in G ermany. E thnic and Racial Studies 24, 531-548.

Castles, S. (1998): "The Challenge of Diversity: Integration and Pluralism in Societies of Immigration'. Journal of Intercultural Studies 19 (1), 105-113.

- (2000): E thnicity and G lobalization: from Migrant W orker to Transnational Citizen. London: Sage.

- (2002): 'Migration and community formation under conditions of globalization,' International Migration Review 36 (4), 1143-68.

Castles, S., M. Kalantzis, B. Cope, and M. Morrissey (1988): Mistaken Identity: M ulticulturalism and the D emise of $\mathrm{N}$ ationalism in A ustralia. Sydney: Pluto Press.

Chicago Cultural Studies Group (1994): 'Critical multiculturalism'. In: D. T. Goldberg (ed.): M ulticulturalism: A C ritical Reader. Oxford: Blackwell, 114-39.

Christiansen, F. and U. Hedetoft (eds) (2004): The Politics of Multiple Belonging. Aldershot: Ashgate.

CLRAE [Standing Conference of Regional Authorities of Europe](1992): E urope 1990-2000: Multiculturalism in the City. The Integration of Immigrants. Strasbourg: Council of Europe, Studies and Texts No. 25.

Cohen, R. (1997): G lobal D iasporas: A n Introduction. London: UCL Press.

Comaroff, J.L. (1996): 'Ethnicity, nationalism and the politics of difference in an age of revolution'. In: E.N. Wilmsen and P. McAllister (eds): The Politics of 
D ifferenœ: E thnic Premises in a W orld of Power. Chicago: University of Chicago Press, 192-83.

Delanty, G . (2003): C ommunity. London: Routledge.

Eller, J.D . (1997): 'Anti-anti-multiculturalism'. A meriman A nthropologist vol. 99, no. 2, 249-56.

Entzinger, H. (2000): The Dynamics of Integration Policies: A Multidimensional Model'. In: R. Koopmans and P. Statham (eds): Challenging Immigration and E thnic Relations Politics: Comparative E uropean Perspectives. Oxford: Oxford University Press, 97-118.

- (2003): 'The Rise and Fall of Multiculturalism: The Case of the Netherlands'. In: C. Joppke and E. Morawska (eds): Toward A ssimilation and Citizenship; Immigration in L iberal N ation-States. London: Palgrave Macmillan, 59-261.

Eriksen, T. H. (1997): 'Multiculturalism, Individualism and Human Rights: Romanticism, the Enlightenment and Lessons from Mauritius'. In: R. Wilson (ed): H uman Rights, C ulture and C ontex t: A nthropological Perspectives. London: Pluto, 49-69.

- (2002): E thnicity and N ationalism. London: Pluto.

Extra, G., and K. Yagmur (2002): Language D iversity in Multicultural E urope. Comparative Perspectives on Immigrant Minority Languages at $\mathrm{H}$ ome and at School. UNESCO.

Faist, T. (2000a): Transnationalization in international migration: implications for the study of citizenship and culture'. E thnic and Racial Studies 23 (2), 189-22.

- (2000b): The V olume and D ynamics of International M igration and Trans- national Social Spaces. O xford: Clarendon Press.

Favell, A. (1998): 'To Belong or not to Belong: the Postnational Question'. In: A. Favell and A. Geddes (eds): The Politics of Belonging: Migrants and Minorities in Contemporary E urope. Aldershot: Ashgate.

- (2001): 'Integration Policy and Integration Research in Europe: a Review and Critique'. In: A. Aleinikoff and D. Klusmeyer (eds): Citizenship Today: G lobal Perspectives and Practios. Washington DC: Brookings Institute/ Carnegie Endowment for International Peace, 349-399.

- (2001): Philosophies of Integration: Immigration and the Idea of Citizenship in Franœ and B ritain. Basingstoke: Palgrave.

Foner, N. (1997): What's new about transnationalism? New York immigrants today and at the turn of the century. D iaspora 6 (3),355-75. 
Geertz, C. (1986): 'The uses of diversity'. Michigan Q uarterly Review vol. 25, no. 1, 105-23.

Gilroy, P. (2004): A fter E mpire: M elancholia or C onvivial C ulture? London: Routledge.

Giroux, H.A. (1994): 'Insurgent multiculturalismand the promise of pedagogy'. In:

D.T. Goldberg (ed): M ulticulturalism: A C ritical Reader. Oxford: Blackwell, 32543.

Glick Schiller, N., L. Basch and C. Szanton Blanc (eds) (1992): Toward a Transnational Perspective on Migration. New York: New York Academy of Sciences.

Goldberg, D.T. (Ed) (1994b): M ulticulturalism: A C ritical Reader. Oxford: Blackwell.

Goodenough, W.H. (1976): 'Multiculturalism as the normal human experience'. A nthropology and E ducation Q uarterly vol. 7, no. 4, 4-7.

Grillo, R., and J. C. Pratt. (2002): The Politics of Recognizing D ifferenœ: M ulticulturalism Italian-Style. Aldershot: Ashgate.

Guarnizo, L.E., A. Portes and W. Haller (2003): 'Assimilation and transnationalism: Determinants of transnational political action among contemporary migrants'. A merican Journal of Sociology 108 (6), 1211-48.

Gupta, Akhil and James Ferguson (1992): 'Beyond "culture": space, identity, and the politics of difference'. C ultural A nthropology vol. 7, 6-23.

Gutman, A. (ed) (1992): Multiculturalism and the 'Politics of Recognition'. Princeton: Princeton University Press.

Hage, G. (1998): W hite N ation: Fantasies of W hite Supremacy in a Multicultural Society. Sydney: Pluto Press.

Hall, S. (2001): 'The multicultural question'. Milton Keynes: 0 pen University Pavis Papers in Social and C ultural Research no. 4.

Hartman, D. And J. Gerteis (2005): 'D ealing with diversity: Mapping multiculturalism in sociological terms'. Sociological Theory 23 (20), 218-40.

Heckmann, F., and D. Schnapper (eds) (2003): The Integration of Immigrants in E uropean Societies. N ational D ifferences and Trends of C onvergence. Stuttgart: Lucius \& Lucius.

Hirschman, C. (1982): 'America's melting pot reconsidered'. A nnual Review of Sociology 9, 397-423.

Hollinger, D. (1995): Postethnic A merica: Bejond Multiculturalism. New York: Basic Books 
Horton, J. (1993): 'Liberalism, multiculturalism and toleration'. In: J. Horton (ed.): L iberalism, Multiculturalism and Toleration. London: Macmillan, 1-17.

Ireland, P. (1994): The Policy Challenge of Ethnic D iversity: Immigrant Politics in France and Switzerland. Cambridge, Ma.: Harvard University Press.

Itzigsohn, J. and S. Giorguli-Saucedo (2002): 'Immigrant incorporation and sociocultural transnationalism'. International Migration R eview 36 (3), 766-98.

- - (2005): 'Incorporation, transnationalism, and gender: Immigrant incorporation and transnational participation as gendered processes'. International Migration Review 39 (4), 895-920.

Janoski, T. \& E. Glennie (1995): The integration of immigrants in advanced industrial nations'. In: M. Martiniello (ed.): Migration, Citizenship and E thno$\mathrm{N}$ ational Identities in the E uropean U nion. Aldershot: Avebury, 11-39.

Joppke, C. (ed.) (1999): Immigration and the N ation-State: The U nited States, G ermany and $\mathrm{G}$ reat Britain. Oxford: Oxford University Press.

- - (1998): Challenge to the $\mathrm{N}$ ation-State: Immigration in W estern E urope and the United States. Oxford: Oxford University Press.

Joppke, C. and E. Morawska (2003): 'Integrating Immigrants in Liberal NationStates'. In: C. Joppke and E. Morawska (eds): T oward A ssimilation and Citizenship: Immigrants in L iberal N ation-States. Basingstoke: Palgrave Macmillan, IX, 243.

Kobayashi, A. (1993): 'Multiculturalism: Representing a Canadian Institution'. In: J. D uncan and D . Ley (eds): Plaœ/ C ulture/ Representation. London: Routledge, 20531.

Kastoryano, R. (ed.) (2002): N egotiating Identities: States and Immigrants in France and $\mathrm{G}$ ermany. Princeton, Oxford: Princeton University Press.

King, D. (2005): 'Facing the future: America's post-multiculturalist trajectory'. Social Policy and A dministration 39 (2), 116-29.

Koopmans, R., and P. Statham (eds) (2000): Challenging Immigration and E thnic Relations Politics: Comparative E uropean Perspectives. Oxford: Oxford University Press.

Kyambi, S. (2005): N ew Immigrant C ommunities: N ew Integration Challenges? London: Institute for Public Policy Research.

Kymlicka, W. (1989): L iberalism, C ommunity and C ulture. Oxford: Clarendon.

- (ed.) (1995): The Rights of M inority C ultures. Oxford: Oxford University Press.

- (1995): Multicultural Citizenship: a Liberal Theory of Minority Rights. Oxford: Clarendon Press. 
- (2003): 'Immigration, Citizenship, Multiculturalism: Exploring the Links'. In: S. Spencer (ed.): The Politics of Migration: Managing 0 pportunity, Conflict and Change. Oxford: Blackwell, 195-208.

Kymlicka, W. and W. J. Norman (eds) (2000): Citizenship in D iverse Societies. Oxford: Oxford University Press.

Lamphere, L., (ed.) (1992a): Structuring D iversity: E thnographic Perspectives on the N ew Immigration. Chicago: University of Chicago Press.

Levitt, P. (2001a): 'Transnational migration: Taking stock and future directions'. G lobal N etworks 1 (3), 195-216.

- (2001b): The Transnational Villagers. Berkeley: University of California.

- (2003): 'Keeping feet in both worlds: Transnational practices and immigrant incorporation in the United States'. In: C. Joppke and E. Morawska (eds): T oward A ssimilation and Citizenship. Basingstoke: Palgrave, 177-94.

Lynch, J., C. Modgil and S. Modgil (eds) (1992): C ultural D iversity and the Schools (4 vol.s). London: Falmer Press.

Martiniello, M. (ed.) (1995): Migration, Citizenship and E thno-N ational Identities in the E uropean U nion. Aldershot: Avebury.

- (ed.) (1998): Multicultural Policies and the State: a Comparison of Two E uropean Societies. Utrecht: ERCOMER.

McLennan, G . (1995): Pluralism. Buckingham: Open University Press.

McNeill, W.H. (1986): Polyethnicity and N ational Unity in W orld H istory. Toronto: Toronto University Press.

Mendus, S. (1989): T oleration and the L imits of L iberalism. London: Macmillan.

Modood, T. and P. Werbner (1997): The Politics of Multiculturalism in the N ew E urope: Racism, Identity, and C ommunity. London: Zed Books.

Morawska, E. (1999): "The new-old transmigrants, their transnational lives, and ethnicization: A comparison of 19th/20th and 20th/21st C situations'. Florence: European University Institute Working Papers E U F No. 99/ 2.

- (2003): 'Immigrant transnationalism and assimilation: A variety of combinations and the analytic strategy it suggests'. In: C. Joppke and E. Morawska (eds): Toward A ssimilation and Citizenship. Basingstoke: Palgrave, 133-76.

Niessen, J. (2000): D iversity and Cohesion. N ew Challenges for the Integration of Immigrants and M inorities. Council of Europe.

Parekh, B. C. (1991) 'British citizenship and cultural difference'. In: G . Andrews (ed.): Citizenship. London: Lawrence \& Wishart, 183-204. 
- (1994): 'Equality, faimess and limits of diversity'. Innovation 7 (3), 289-308.

- (2000): The Future of Multi-E thnic Britain: Report of the Commission on the Future of M ulti-E thnic B ritain. London: Profile (Runnymede Trust).

- (2000): Rethinking Multialturalism: Cultural Diversity and Political Theory. Basingstoke: Macmillan; Palgrave.

Penninx, R., K. Kraal, M. Martiniello and S. Vertovec (2004a): Citizenship in E uropean Cities: Immigrants, Local Politics and Integration Polices. Aldershot: Ashgate.

Portes, A. (2001): 'The debates and significance of immigrant transnationalism'. G lobal N etwork 1 (3), 181-93.

Portes, A. and R. Rumbaut (2001): L egacies: The Story of the Immigrant Second $G$ eneration. Los Angeles, CA: the University of California Press.

- (2003): 'Conclusion: Theoretical convergencies and empirical evidence in the study of immigrant transnationalism'. International Migration Review 37 (3), 87492.

Portes, Alejandro, Luis E. Guarnizo and Patricia Landolt (eds) (2000): Transnational Communities. Special issue of Ethnic and Racial Studies 22 (2), 217-477.

Prins, B., and B. Slijper (2002): 'Multicultural Society Under Attack: Introduction'. Journal of International Migration and Integration 3, 313-328.

Rex, J. \& B. Drury (eds) (1994): E thnic Mobilisation in a Multi-Cultural E urope. Aldershot: Avebury.

Sandercock, L. (2003): Cosmopolis II: Mongrel Cities of the 21st Century. London: Continuum.

Sanjek, R. (1998): The F uture of U s A ll: Race and N eighborhood Politics in N ew Y ork City. Ithaca: Cornell University Press.

Schlesinger, A. M. (1991): The Disuniting of A merica: Reflections on a Multiaultural Society. New York: W.W. Norton \& Co.

Shohat, E. \& R. Stam (1994): U nthinking E urocentrism: Multialturalism and the M edia. New York: Routledge.

Snel, E., G. Engbersen and A. Leekres (2006): Transnational involvement and social integration'. G lobal N etworks 6 (3), 285-308.

Soysal, Y.N. (1994): Limits of Citizenship: Migrants and Postnational Membership in E urope. Chicago: University of Chicago Press.

Stolcke, V. (1995): Talking Culture: New Boundaries, New Rhetorics of Exclusion in Europe'. Current A nthropology 36, 1-24. 
Statham, P. (2003): 'New Conflicts about Integration and Cultural Diversity in Britain: The Muslim Challenge to Race Relations'. In: R. Cuperus, K. A. Duffek, and J. Kandel (eds): The Challenge of D iversity. Innsbruck, Wien, München, Bozen: Studien Verlag.

Taylor, C. (1992): Multiculturalism and 'The Politics of Recognition'. Princeton: Princeton University Press.

Turner, T. (1993): 'Anthropology and Multiculturalism: What is Anthropology that multiculturalists Should be Mindful of it?'. C ultural A nthropology 8, 411-29.

Vertovec, S. (1996): 'Multiculturalism, Culturalism and Public Incorporation'. E thnic and Racial Studies 19 (1), 49-69.

- (1998) 'Multi-multicutluralisms'. In: M. Martiniello (ed.): Multicultural Policies and the State. Utrecht: ERCO MER, 25-38.

- (1999): 'Introduction'. In: S. Vertovec (ed.): Migration and Social Cohesion. Aldershot: Edward Elgar, xi-xxxvii.

- (2001): 'Transnationalism and identity'. Journal of $E$ thnic and M igration Studies 27 (4), 573-82.

- (2004a): 'Migrant transnationalism and modes of transformation'. International Migration Review 38 (3), 970-1001.

- (2004b): 'Cheap Calls: the social glue of migrant transnationalism'. Global N etworks 4 (2), 219-24.

- - (2007): 'Super-diversity and its implications'. E thnic and Racial Studies 29 (6).

Vertovec, S. and R. Cohen (1999): Introduction. In: S. Vertovec and R. Cohen (eds): M igration, D iasporas and Transnationalism. Cheltenham: Edward Elgar, xiiixxviii.

Watson, C. W. (2000): M ulticulturalism. Buckingham: O pen University Press.

Wax, M. L. (1993): 'How culture misdirects multiculturalism'. A nthropology and E ducation Q uarterly vol. 24, no. 2, 99-115.

Werbner, P. and T. Modood (eds) (1997): D ebating C ultural H ybridity: M ulti-cultural Identities and the Politics of A nti-Racism. London: Zed

Young, I. M. (1990): Justice and the Politics of Difference. Princeton: Princeton University Press.

Yuval-D avis, N. (1992): 'Fundamentalism, multiculturalism and women in Britain'. In: J. D onald and A. Rattansi (eds): 'Raœ', C ulture and D ifference. London: Sage, 278-91. 
Zachary, G. P. (2003): The D iversity A dvantage: Multicultural Identity in the N ew W orld E conomy. Boulder, Colo.: Westview.

Zolberg, A. and W. L. Long (1999): Why Islam is like Spanish: Cultural Incorporation in Europe and the United States'. Politics and Society 27, 5-38. 



\title{
Fremdbilder - Feindbilder? E in Islam-Bild in der deutschen Presse Zur Kopftuch-D ebatte im SPIEgEL 1998-2008
}

\author{
E mest W .B. H ess-L üttich
}

\section{Bild-Geschichten}

Können Bilder lügen? Bilder zeigen die Wirklichkeit, heißt es, sie bilden ab, was wirklich war. Sind sie also wirklich wahr? Natürlich nicht. Nicht erst seit den Segnungen der digitalen Technik wird uns zunehmend bewußt, wie Bilder Realitäten schaffen. Am 31. März 2003 zum Beispiel erschien auf der ersten Seite der L os A nge les Times ein eindrucksvolles Photo vom dritten Golfkrieg, das um die Welt ging. Irgendwer wunderte sich dann, daß dieselben Personen auf dem Photo zweimal zu sehen sind. D er Reporter Brian Walski, der das Photo geliefert hatte, räumte später ein, zwei Bilder digital zu einem verschmolzen zu haben, um es ausdrucksvoller zu machen. ${ }^{1}$ Bilder wirken intensiver, bleiben länger im G edächtnis haften, besonders wenn sie an bereits vorhandene Bilder im Kopf anknüpfen (cf. Straßner 2002: 13; Krämer \& Walter 1996: 33 f.). „Inzwischen haben wir alle erfahren“ resümiert ein

1 http:/ / www.rhetorik.ch/ Bildmanipulation/ Bildmanipulation.html [31.07.2008]. Der Vortrag am 24.02.2005 in Jaipur (Rajastan, Indien) wurde im D ezember 2004 geschrieben und für die Zwecke dieser Publikation im Juli 2008 aktualisiert und ergänzt. Grundaussagen und Vortragsstil wurden jedoch beibehalten. Amr Shaker Hammad Abu Zeid hat dafür im Rahmen seiner von mir gemeinsam mit Kollegen der Al-Azhar Universität Kairo betreuten Magisterarbeit Material kompiliert, das hier teilweise Verwendung findet, ohne freilich den dort vorgenommenen (z.T. einseitig pro-islamischen) Wertungen zu folgen. Die Quellen werden im Text durch Angabe der Heftnummer, des Erscheinungsjahres und der Seitenzahl zitiert. 
früherer Spiegel-Redakteur und späterer Intendant des Deutschland-Radios, „daß sich die Welt mit Bildern viel besser belügen läßt, als mit Worten. Hollywood ist überall" (Mast ed. 1998: 210).

D er Nebentext des Bildes steuert dessen Rezeption. Seine Funktion, Informationen darüber zu liefern, von wem das Bild stammt, wo es aufgenommen wurde und was damit bezweckt wird, kann zur kreativen Konstruktion von Wirklichkeit umfunktioniert werden (Mast 1998: 291). So berichtet der Spiegel unter dem Titel „Kräfte des Bösen“ über Reaktionen auf den Terroranschlag auf das World Trade Center in New York City: „In Nahost reagierten die Menschen mit aufrichtiger Trauer oder blankem Hass: Moderat äußerten sich Teheran und Tripolis, Bagdad verbreitete G olfkriegsparolen“ (Spiegel 38/ 2001: 154). D ie ,aufrichtige Trauer' und den ,blankem Hass' illustrieren zwei Bilder in direktem Kontrast: das eine zeigt Israelis in ernster Betroffenheit beim Blutspenden in Jerusalem, das zweite feiernde Palästinenser, die im Freudentaumel G ewehrsalven abfeuern (Abb. 1 a\&b).
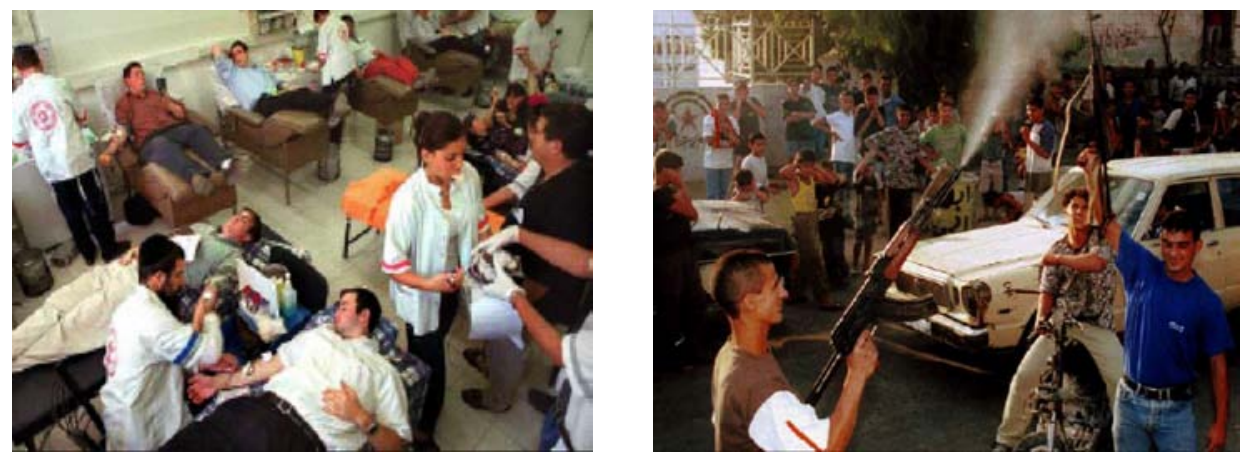

Abb. 1: „Aufrichtige Trauer" und „Blanker Hass"

Gut und böse sind hier übersichtlich verteilt: „Trauer und Entsetzen weltweit, doch Jubel in Ost-Jerusalem, im Westjordanland und in den palästinensischen Flüchtlingslagern im Libanon“ (ibid.). Und weiter: Israel fand sich „in seinem Kampf gegen den Terror bestätigt, nachdem es sich jahrelang weitgehend allein gelassen fühlte mit seinen Warnungen vor dem ,extremistischen islamischen Terror"“ (ibid.). Allerdings: „es waren die einzigen Jubelaufnahmen, die die Fernsehstationen nach dem Attentat verbreiten konnten“" (ibid.). D as Bild läßt die Freude der (aller) Palästinenser am grausamen Angriff als Normalfall und nicht als Ausnahme erscheinen. Im Sommer 2008 könnte man exakt dieselben Bilder wieder verwenden oder ähnliche aufnehmen - allenfalls würde man den Ausdruck „die Palästinenser" ersetzen durch "die Hamas". Sie scheint entschlossen, ihr Bild in der (westlichen) Welt mit jedem Tag neu zu bestätigen. Es entbehrt nicht der tragischen Ironie, daß palästinensische Fatah-Anhänger in G aza sich im Sommer 2008 vor der Mordlust ihrer Glaubensbrüder nur durch Flucht nach Israel retten konn- 
ten, wo sie medizinisch versorgt und dann ins Westjordanland transportiert wurden.

Die nachhaltige Wirkung der Bilder wird in der Kognitionspsychologie dadurch erklärt, daß sie anders als Wörter sowohl in einem visuellen G edächtnisareal als auch in einer verbalen Sinnkopie gespeichert werden. Wir denken nicht nur in abstrakten Prozessen, sondern auch sinnlich in Bildern (cf. Straßner 2002: 19 f.; Krämer \& Walter 1996: 38; D oelker 1997: 37). Neben ihrer emotionalen Wirkung liegt die Stärke der Bilder in ihrer Anschaulichkeit, Übersichtlichkeit, D arstellung der räumlichen Zusammenhänge; sie werden meist leichter und schneller wahrgenommen und verstanden als ein verbaler Text. Man braucht nur eine Sekunde, um ein kompliziertes Bild aufzunehmen, während man in dieser Zeit nur fünf bis zehn Wörter lesen kann. D iese Überlegenheit des Bildgedächtnisses läßt das Bild länger wirken als der Text (cf. Krämer \& Walter 1996: 26 ff.; Stöckl 2004). Es aktiviert zudem sowohl die inneren Gedächtnisbilder als auch den zugehörigen sprachlichen Ausdruck. Deshalb kommt es entscheidend darauf an, mit welchen Begriffen die Bilder bzw. mit welchen Bildern die Begriffe im Kopf des Betrachters verbunden werden. Die moderne Kriegsberichterstattung hat, soweit sie staatlich autorisiert und gesteuert ist („embedded journalists“) aus diesen Befunden längst praktische Konsequenzen gezogen.

Wenn die Medien bestimmte Begriffe im Kopf des Betrachters mit bestimmten festgelegten Bildmustern (oder diese mit jenen) verbinden, erzielen sie oft manipulative Wirkungen, indem sie sich auf gemeinsame bildliche Assoziationen verlassen. Eine verläßliche Assoziation dieser Art ist die Illustration von Terror durch Bilder von betenden Muslimen oder von Mekka. So zeigt der Spiegel (40/2003) ein Bild von betenden Muslimen im Frankfurter Flughafen mit dem Untertitel „Aggressiver Geltungsanspruch“ im Zusammenhang mit der Rede von Islamisten in D eutschland (Abb. 2).

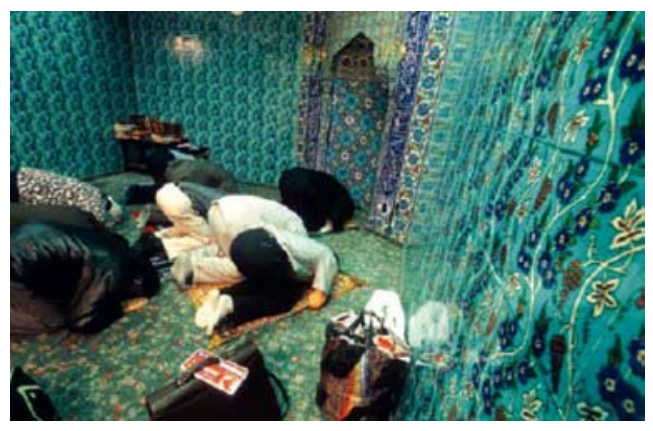

Abb. 2: Moschee (im Frankfurter Flughafen): „Aggressiver G eltungsanspruch“

In einem anderen Bild im selben Bericht sieht man ein Bild von Pilgern in Mekka. Das Bild hat den Untertitel: „Aufopferung und Märtyrertum um Allahs willen“ in 
Anspielung auf die Terroranschläge, die von den Terroristen als Märtyrertum bezeichnet werden (Abb. 3):

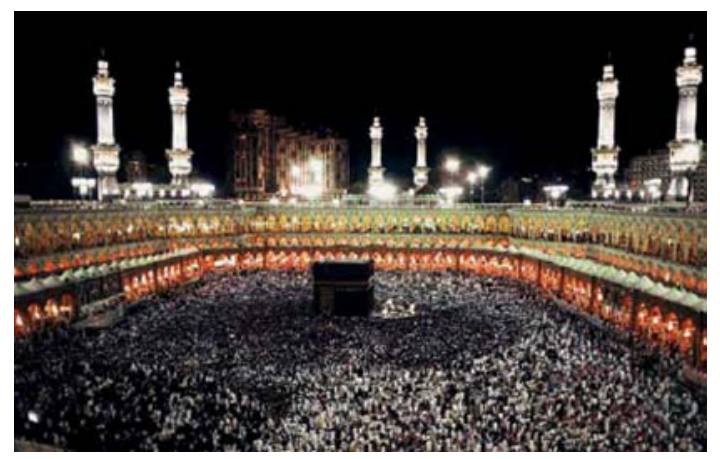

Abb. 3: „Aufopferung und Märtyrertum um Allahs willen“

\section{Feind-Bilder}

Ein Wort genügt, als Signal oder Bild-Impuls verwendet, um bestimmte Vorstellungen, G efühle, auch Phobien aufzurufen, die teilweise auf Vor-Urteilen gründen und sich alsbald zu Urteilen, vielleicht Verurteilungen verfestigen. Es gibt viele Arten von Stereotypen, rassische, nationale, kulturelle, politische, berufliche, soziale, sexuelle usw. Stereotypen sind negative Bilder von Gruppen, sie verbinden Mitglieder einer bestimmten Kategorie mit bestimmten Bildern oder Charakteristika, die automatisiert (und meist tatsachenwidrig) assoziiert werden, wenn man die Kategorie bzw. deren Mitglieder wahrnimmt nach dem Muster „A ist X “, also Typ A (Mitglied der Gruppe A) entspricht dem Bild X (cf. Prokop 1995: 185). Positive Erfahrungen mit Mitgliedern des A-Typs können das Bild kaum irritieren (das ist die sog. ,ja-aber-Konstruktion': okay, $\mathrm{A}_{1}$ oder $\mathrm{A}_{2}$ sind $\mathrm{Y}$, aber alle anderen aus $\mathrm{A}$ sind X - ibid.: 189). Die einmal einer solchen Kategorie zugeordneten Bilder dienen der Rationalisierung und Rechtfertigung von Vorurteilen. Stereotypen können auch Erscheinungen, Handlungen oder andere Lebewesen betreffen. Sie zeichnen meist ein vereinfachtes, schematisches Weltbild und leiten das D enken in die vom je eigenen Gruppeninteresse bestimmte Richtung, bis sie sich verfestigen zu sog. „Feindbildern' (ibid.: 190; cf. Schaff 1980: 45).

Die wichtigsten Merkmale stereotypisierter Feindbilder im Sinne negativer Vorstellungsklischees sind (frei nach Spillmann) Mißtrauen, Schuldzuweisung, negative Antizipation, Identifikation mit dem Bösen, Nullsummendenken, antagonistische Isolation (cf. Spillmann \& Spillmann 1989: 3; Wittkämper ed. 1992: 64). Feindbilder sind Bilder, die wir uns selber malen, keine Abbilder, die den andern wiedergeben, wie er wirklich ist. Fremd- und Feindbilder entstehen in wechselseitigem Prozeß. Das eigene Sein wird durch die Ausgrenzung des anderen definiert. Das 
Fremde ist das potentiell Feindliche. Feindbilder, sagte Marion Gräfin D önhoff (in der Z eit), „Feindbilder haben so viele Vorteile: Sie solidarisieren, sie entheben der Mühe des eigenen D enkens; Vorurteile werden legitimiert, Diskriminierung wird sanktioniert, alle Andersartigen werden stigmatisiert" (Dönhoff 1987).

Auch wenn die Medien Feindbilder nicht selber produzieren, so tragen sie doch große Verantwortung für deren Verbreitung und Verstärkung. Heute sehen viele ,im Westen' den Islam jenen Platz einnehmen, den während der Zeit des Kalten Krieges der Kommunismus innehatte. Uralte, historische' Ängste werden wiederbelebt, auch in Europa, wo man den Islam jahrhundertelang als Bedrohung empfand, mindestens bis zur Niederlage der Türken vor Wien 1683. D er frühere $G$ eneralinspekteur der Bundeswehr, Klaus Naumann, hat eine neue ,grüne G efahr' ausgemacht: „D ie rote $G$ efahr wird von der grünen $G$ efahr abgelöst, der Krisenbogen reicht von Marokko bis Pakistan“ (D er Spiegel 01/ 1995: 105; Hervorhebung v. Verf., EHL).

,Grün', so muß hier eingeflochten werden, steht hier nicht mehr - wie bislang in D eutschland und Mitteleuropa meist assoziiert - für Umweltbewegung und gesunde Nahrung, sondern heute auch im Westen immer mehr für den Islam, für den Grün von Anbeginn an die Farbe des Propheten ist. Im Koran und in der Hadith-Literatur finden sich Substantive und Adjektive, die für ,grün' stehen (in der Beschreibung paradiesischer Gärten oder in etlichen Erwähnungen von Gewändern, D ecken, Teppichen usw.). ${ }^{2}$ D ie Farbe wird nachweislich schon früh von den Anhängern Muhammads als politisches Symbol eingesetzt, um auf die heilsgeschichtlichen Konnotationen zu verweisen bzw. sie zu evozieren. So wird sie neben der Kalligraphie zum wichtigsten visuellen Stilelement islamischer Ästhetik: als ,Zeichen' islamischer Identität, die heute in Bucheinbänden und Websitegestaltung, Logos muslimischer Unternehmen oder Fernsehsender ihren ubiquitären Ausdruck findet.

So wird eine physikalische Eigenschaft semiotisch aufgeladen und markiert über die symbolische Funktion als ästhetisches Medium kontemplativer Erbauung hinaus immer auch den politischen Anspruch religiöser Superiorität sowohl nach außen als auch den Anspruch ,rechtgläubiger' Legitimität nach innen: so hat die schiitische Ikonisierung der grünen Kopfbedeckungen des nach schiitischer Auffassung einzig rechtmäßigen Nachfolgers des Propheten, Ali ibn Abu Talib (seines Schwiegersohns), zugleich die Funktion der Abgrenzung zu sunnitischen Traditionen. D ie semiotische D oppelfunktion islamischer Farbsymbolik als Zeichen autoritär beanspruchter ,Rechtgläubigkeit' ist auch G egenstand eines Forschungsprojektes an der Universität Bern (cf. Leuenberger 2006: 15).

Wer umgekehrt die ,grüne G efahr' beschwört (so wie einst die ,gelbe Gefahr' periodisch Konjunktur massenmedialer Katastrophenszenarien hatte), ruft ebenfalls Traditionen politischer Farbsymbolik auf: so wie grün' etwa in tropischen

2 Als Hadith-Literatur gelten die redigierten Sammlungen der überlieferten Aussagen des Propheten Muhammad und die Erzählungen über seine vorbildhaften Taten und Eigenschaften. 
D schungelgebieten weniger für ,gesunde Ernährung' steht als vielmehr für dunkle $\mathrm{G}$ efahr und unbestimmte Bedrohlichkeit, so wird heute im Westen das islamische G rün leicht mit dem aggressiven D jihad assoziiert. Man hört die Frage unverblümt heraus: Gilt es wieder, sich zu rüsten, wie zur Zeit der O smanen, die europäische Vorstellungen vom Islam lange Zeit geprägt haben? Im kollektiven $\mathrm{Ge}$ -

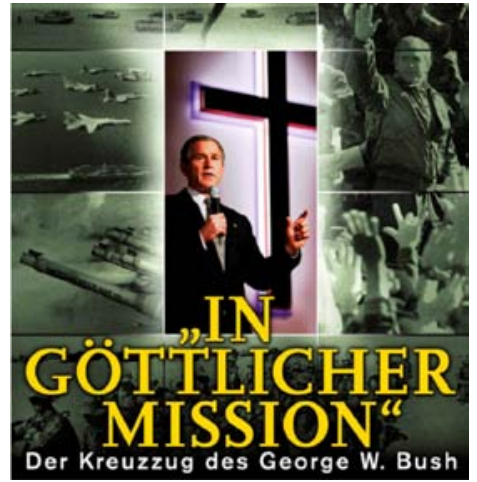

Abb. 4: „In göttlicher Mission“. Der Kreuzzug des G eorge W. Bush dächtnis scheinen sie nach wie vor lebendig, wenn man Teilen der Presse glaubt, die den Islam stets und stereotyp mit G ewalt verbindet und als eine (immer noch oder heute wieder) aggressiv-expansionistische Religion bezeichnet, von der eine Bedrohung ausgehe für die demokratische Kultur. Der Spiegel jedenfalls sieht, wenn auch im kritischen Zitat, den amerikanischen ,Kriegspräsidenten' (wie er sich selbst gern nannte) George W. Bush bereits „in göttlicher Mission" unterwegs zu neuen Kreuzzügen gegen die Welt des Islam als dem neuen ,Reich des Bösen'

(D er Spiegel 08/ 2003: Cover). D as Bild des Titelblattes zeigt G eorg W. Bush während seiner Rede über "the crusade" vor dem Irakkrieg, hinter ihm ein großes Christen-Kreuz an der Wand, umrahmt von den Insignien des Krieges (Abb. 4).

Da der Islam als Bedrohung im europäischen Kollektivgedächtnis nach wie vor fest verankert scheint, können die Medien bei einschlägigem Anlaß in stereotyper Assoziation in Wort und Bild jederzeit ohne weiteres an die Zeit der ,Türkenkriege' anknüpfen und die dazugehörige kulturelle Erinnerung an „die Eroberung Konstantinopels" abrufen, verbunden mit den davon überlieferten Greueltaten der osmanischen Krieger (D er Spiegel 40/ 2003: 92 - Abb. 5).

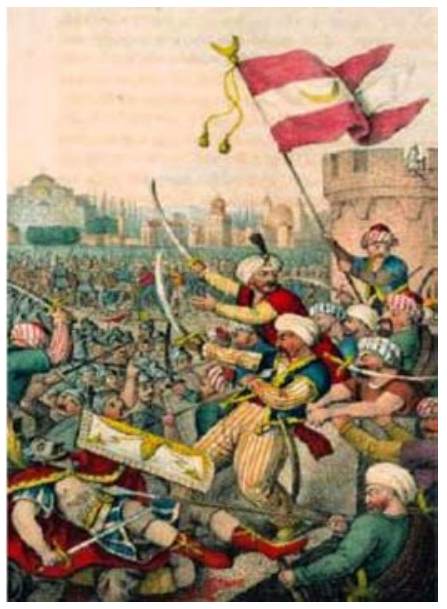

Abb. 5: Eroberung Konstantinopels: „Autoritär und despotisch" 
Die wechselseitigen Feindbilder sind auf beiden Seiten nicht neu, auf der westlichen Seite gibt es sie seit der ersten Ausdehnung des Islam bis zum Frieden von Karlowitz 1700 (cf. Eickhoff 2008), auf islamischer Seite seit den K reuzzügen (cf. Rotter ed. 1993: 219). Der Gegensatz hat Vorstellungen vom Islam im europäischen Bewußtsein verankert, die jederzeit aktiviert werden können. Im Westen wird das Feindbild als mediales Großereignis erstmals mit der Ölkrise 1973 (Topos: ,die Araber drehen uns den Ölhahn ab, und wir sind machtlos') und dann wieder mit der islamischen Revolution im Iran 1978 (Topos: statt Befreiung von der Monarchie des Schah Reza Pahlevi muslimischer Tugend-Terror fundamentalistischer Mullahs) flächendeckend reaktiviert und erwacht nach „den Ereignissen“ (wie viele Araber euphemistisch sagen), also den Terroranschlägen vom 11.09.01 und den darauf folgenden Reaktionen zu neuer und - dank der täglichen Attentate versprengter Al-Q aida G ruppen und der unverhüllten Atomdrohungen des messianischen iranischen Präsidenten, der Israel „von der Landkarte tilgen“ will - dauerhaft anhaltender Blüte. Seither gewinnen Schlüsselwörter wie „Kreuzzug' und ,Djihad' wieder einen bedrohlichen Klang (Strobl 1997). Übrigens durchaus auf beiden Seiten: wenn Bush jr. von ,crusade' spricht, wird das in der arabischen Welt leicht wörtlich genommen, wie die österreichische Presse nach den Anschlägen auf das New Yorker World Trade Center meldet: „Anspannung in der arabischen Welt - Angst vor ,Kreuzzug'“" (D ie Presse v. 20.09.2001). ${ }^{3}$

Umgekehrt unterscheiden auch westliche Politiker noch nicht immer sehr subtil zwischen Islam und Terror - so ließ sich die europäische Politikerin Pia Kjaersgaard, Vorsitzende der rechtspopulistischen Dänischen Volkspartei (DF) von der Presse undementiert zitieren, was sie in der $\mathrm{G}$ eneraldebatte des Kopenhagener Parlaments über Ausländer stolz verkündet hatte: „D er Kampf gegen den Terror ist auch ein Kampf gegen den Islam" (D ie Presse v. 08.10.2001; Suchanfrage 06.08.08: 500 Treffer). D er Spiegel (25/ 2001: 50) wendet das martialische Argument ins G eistesgeschichtlich-G rundsätzliche:

Der New Yorker Terrorangriff der islamischen Fundamentalisten zielte auch auf das liberale Credo des Abendlands. D och Europäer und Amerikaner wollten sich von den „G otteskriegern" nicht einreden lassen, sie hätten bloß Wohlstand zu bieten: Ihre geistige Tradition ist es wert, verteidigt zu werden - auch gegen den Islam.

Die Grenze wird deutlich markiert, moralische Werte und politisches Ethos des Westens werden als denen des Islams zuwiderlaufend akzentuiert. Die österreichische Presse zitiert (in ihrer Ausgabe v. 27.06.2002) etwa den renommierten israelischen Historiker Robert Solomon Wistrich ebenfalls in diesem Sinne:

3 Wer auf ihrer Webseite heute das Stichwort aufruft, erhält sogleich ca. 250 Rückmeldungen, was nicht für eine einmalige Überspitzung der Formulierung spricht, sondern für ihre systematisch kontinuierliche Verwendung: cf. http:/ / diepresse.com/ [06.08.2008]. 
Der islamische Antisemitismus [verbinde sich] mit dem Kampf gegen die moderne, westliche Zivilisation, die Säkularisierung, die Emanzipation der Frau sowie gegen den Kapitalismus [... ] D ie Attacken des 11. Septembers seien eine Form von „islamischem Faschismus" gewesen, so Wistrich. Dieser sei eine Herausforderung für die ganze westliche Welt.

Der hier gebrauchte Ausdruck vom ,islamischen Faschismus' wird vom amerikanischen Präsidenten aufgegriffen, macht schnell die Runde und ist heute zum geflügelten Wort geworden. In den Medien werden die Anschläge vom 11. September systematisch mit dem Islam verknüpft. In Analysen und Kommentaren wird seither die Frage gestellt, ob G ewalttätigkeit ihm ideologisch innewohne. Vor diesem Hintergrund gewinnen Symbole des Islams markierende, auch stigmatisierende Kraft (cf. Schiffer 2004). So wird in den Medien etwa über das Thema ,Kopftuch' seit dem iconisierten Datum ,nine/ eleven' in anderer Weise berichtet als früher (cf. Thofern 1998). Diese Beobachtung versuche ich abschließend anhand einiger (aus einer Fülle von Material beliebig ausgewählter) Beispiele aus dem deutschen Nachrichtenmagazin D er Spiegel zu veranschaulichen.

\section{Feindbild Kopftuch ?}

Die Kopftuchdebatte steht im Mittelpunkt eines Titelberichts des Spiegel aus der Zeit vor den Anschlägen. Die im baden-württembergischen Schuldienst tätige muslimische Lehrerin Fereshta Ludin hatte die D ebatte mit ihrem Beharren auf dem Tragen des Kopftuches während des Unterrichts ausgelöst und ihr Recht auf Verschleierung eingeklagt. Unter der Überschrift „D ie letzte Schlacht“ stellt der Spiegel die „Frage nach dem Verhältnis von Staat und Religion“, die „durch den Streit um das Kopftuch einer muslimischen Lehramtsanwärterin erneut aktuell geworden" sei.4 Es geht bei diesem Streit um die grundsätzlichere Frage der Trennung zwischen Staat und Religion (jeder Religion) in den staatlichen Institutionen im allgemeinen und den Schulen im besonderen.

Auf den ersten Blick suggeriert der Spiegel-Titel so etwas wie einen von Muslimen geführten Kampf gegen den deutschen Staat um ihr Kopftuch, tatsächlich aber ist es ein Zitat aus einem Kommentar von Micha Brumlik, Professor für Pädagogik in Heidelberg und Mitglied der Jüdischen $G$ emeinde in Frankfurt/ Main, in dem er den Streit über das Kopftuch ironisch als „die letzte Schlacht des christlichen Abendlandes" (ibid.) bezeichnet hatte. Er kritisierte etwa, daß eine aktive Katholikin allein entscheidet (nämlich die damalige Kultusministerin des Landes Baden-Württemberg, Annette Schawan, die inzwischen [2008] als Ministerin für Bildung und Forschung dem Bundeskabinett in Berlin angehört), was ihres Erachtens zum richtigen Islam gehört und was nicht, wenn sie befindet, daß ein Kopftuch

4 Alle Zitate hier und im folgenden sind diesem Bericht entnommen: D er Spiegel 30/1998 v. 20.07.1998: 58 
„nicht zu den religiösen Pflichten einer Muslimin“ gehöre (ibid.). Es ist dieselbe, die gleichzeitig den Habit christlicher Nonnen im Unterricht katholischer Schulen vehement als Ausdruck europäischer Werte verteidigt. Diese Ungleichbehandlung im Angesicht der Verfassungsgebote der Religionsfreiheit, der staatlichen Neutralität in Glaubensfragen und der Trennung von Kirche und Staat beschäftigte dann lange die höchsten $\mathrm{G}$ erichte (cf. den berühmten ,Kruzifix-Beschluß' in Bayern). ${ }^{5}$ $\mathrm{Zu}$ der leichten Verzerrung der Perspektive in der Überschrift paßt auch die Unterschrift zum Bild von zwei verschleierten Muslima im Stuttgarter Landtag auf derselben Seite, die die Einstellung der Ministerin zum Kopftuch mit den Worten zitiert: „Symbol der Abgrenzung und Unterdrückung“ (Abb. 6).

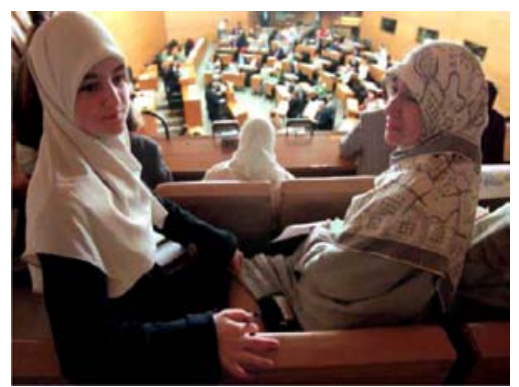

Abb. 6: „Symbol der Abgrenzung und Unterdrückung"

So kann man die Aufmerksamkeit und die Einstellung des Lesers unmerklich steuern. Ebenso gut hätte die Redaktion das (ebenfalls im Text enthaltene) Zitat des Islamwissenschaftlers Peter Heine, Professor für Islamwissenschaften an der Humboldt-Universität in Berlin, unter das Bild setzen können: „Für gläubige Muslime ist das Kopftuch identitätsstiftend" (ibid.). Aber dann wäre der Akzent ein anderer gewesen. D abei liegt der Spiegel bekanntlich ebensowenig auf der Linie der islamischen wie der katholischen Glaubenskämpfer (hier: D er Spiegel 30/ 1998 v. 20.07.98: 58; s. Anm. 5):

In der Tat scheint der Verdacht, daß christliche Werte und säkulare Rechtsnormen im Kopf der Ministerin nicht immer sauber getrennt sind, einiges für sich zu haben.

${ }^{5}$ cf. http:/ / de.wikipedia.org/ wiki/ Kruzifix-Beschluss [06.08.2008]: ,Kruzifix-Beschluß' (ugs. KruzifixU rteil) wird die Entscheidung des Bundesverfassungsgerichts v. 16.05.1995 genannt, mit der Teile der Bayerischen Volksschulordnung für verfassungswidrig und nichtig erklärt wurden, nach denen in jedem Klassenzimmer der Volksschulen in Bayern ein Kruzifix oder zumindest ein Kreuz anzubringen war. D er Kruzifix-Beschluß gilt als bedeutsame Entscheidung zum Verhältnis von Religion und Staat in D eutschland. Das G ericht sah die durch das G rundgesetz uneingeschränkt gewährte Religions- und Glaubensfreiheit der Schüler aus Art. 4 G G verletzt, hier die sog. negative Glaubensfreiheit. In diese dürfe der einfache (Landes-)G esetzgeber nicht im Rahmen sonst oft vorhandener Grundrechtsschranken eingreifen. Darüber hinaus hob das Gericht hervor, daß der Staat nicht nur eine religiöse Neutralitätspflicht aus der Verfassung habe (Art. 4 GG und Art. 140 GG, Art. 137 Abs. 1 Weimarer Reichsverfassung). Er könne sich vielmehr nicht selbst auf Religionsfreiheit oder eine bestimmte Weltanschauung berufen (hier also die christliche), da ein Staat als solches weder einer Religion angehören, noch $\mathrm{G}$ rundrechte für sich in Anspruch nehmen kann. 
Schon nach dem Kruzifix-Urteil des Bundesverfassungsgerichts 1995 hatte sich Schawan schwergetan, das christliche Abendland am Schultor enden zu lassen.

Auch die Bayern reagierten prompt und ergänzten das staatliche Erziehungs- und Unterrichtsgesetz durch einen Zusatz, der das Kreuz in jeder Klasse vorschreibt: „Angesichts der geschichtlichen und kulturellen Prägung Bayerns wird in jedem Klassenraum ein Kreuz angebracht" (Art. 7, Abs. 3, S. 1). Erst Jahre später (am 02.01.2002) entschied der Bayrische Verwaltungsgerichtshof, daß das Kreuz auf Verlangen eines Lehrers im Einzelfall abzunehmen sei (Az. 3 B 98.563). Am 24.09.2003 folgte dann mit der Aufhebung von Urteilen vorheriger Instanzen (mit 5:3 Stimmen) das berühmte ,Kopftuchurteil' des Bundesverfassungsgerichts: „D ie muslimische Lehrerin Fereshta Ludin darf vorerst im Unterricht ihr Kopftuch tragen" (D er Spiegel 40/ 2003 v. 29.09.2003: 8). Im übrigen überließ das Verfassungsgericht es den betroffenen Bundesländern, die Entscheidung darüber zu fällen, das Kopftuch zu verbieten oder zuzulassen.

Seither beschäftigt die Kopftuchfrage die Landesparlamente. Rheinland-Pfalz verzichtete auf eine Regelung und hofft auf common-sense-Lösungen. SchleswigHolstein wollte konsequent sein und an Schulen alle religiösen Symbole untersagen, knickte dann aber vor dem Protest der christlichen Kirchen wieder ein. Zuletzt bestätigte der Verwaltungsgerichtshof Baden-Württembergs (am 14.03.2008) vorinstanzliche Urteile, die generell (unabhängig von G lauben und G eschlecht) das Tragen religiös motivierter Kleidung im Unterricht untersagten, was wiederum die K reuzträger unter den Lehrern aufbrachte; im Jahr zuvor (am 15.01.2007) hatte der Bayrische Verfassungsgerichtshof in etwas gewundener Formulierung verfügt, daß

äußere Symbole und Kleidungsstücke, die eine religiöse oder weltanschauliche Überzeugung ausdrücken, von Lehrkräften im Unterricht nicht getragen werden dürfen, sofern die Symbole oder Kleidungsstücke bei den Schülerinnen und Schülern oder den Eltern auch als Ausdruck einer Haltung verstanden werden können, die mit den verfassungsrechtlichen Grundwerten und Bildungszielen der Verfassung einschließlich den christlich-abendländischen Bildungs- und Kulturwerten nicht vereinbar ist (Vf. 11VII-05: http:/ / www.bayem.verfassungsgerichtshof.de/ [06.08.2008]).

Ähnliche Lösungen sucht Nordrhein-Westfalen mit G esetzen, deren Formulierungen ihre Anwendung nur auf Kopftücher erlaubt, aber nicht auf „Symbole christlicher und abendländischer Kultur". Die absehbare Folge dieses typisch deutschen föderalen Regelungsehrgeizes ist heute zu besichtigen: überall häufen sich die Klagen gegen die juristisch sanktionierte Ungleichbehandlung. Und der Unmut wächst auf beiden Seiten.

Auch D er Spiegel ist verglichen mit seiner früheren Berichterstattung nach dem 11. September 2001 deutlich kritischer gegenüber dem Kopftuch, das zunehmend als Zeichen der islamistischen Intoleranz, des Fundamentalismus, des Terrorismus wahrgenommen wird, als politisches Symbol der Abgrenzung und der Unterdrückung der Frau, als Hindernis gegen die Integration der Muslime in Deutschland. 


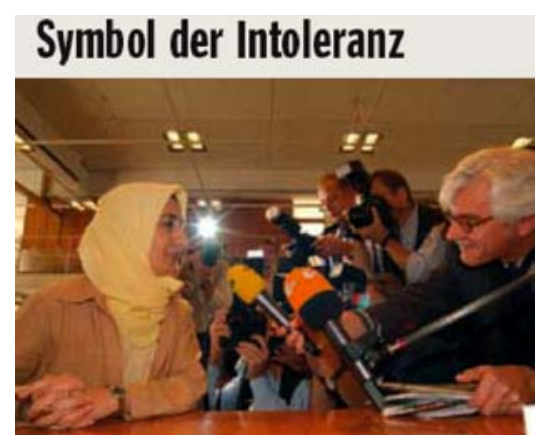

Abb. 7: „Symbol der Intoleranz"
Nach dem zitierten Ludin-Urteil widmet er dem Thema einen über 15 Seiten langen Bericht unter dem Programm-Titel: „Symbol der Intoleranz". ${ }^{6}$ D as Bild dazu zeigt die verschleierte Lehrerin Fereshta Ludin, belagert von Journalisten, denen sie selbstbewußt lächelnd Rede und Antwort steht (D er Spiegel 40/ 2003 v. 29.09.2003: 8) (Abb. 7).

Die Entscheidung des Verfassungsgerichts, es sei Sache der Länder, über Verbot oder Zulassung des Kopftuchs zu entscheiden, wird im

Bericht zu einer Art Auftrag an die Länder umgedeutet, ein entsprechendes Verbot zu erlassen, um den „intoleranten Islam“ einzudämmen (ibid.):

Den Bundesländern bleibt es überlassen, das Symbol eines intoleranten Islam per Gesetz zu verbieten. D enn radikale Muslime verachten die Werte der westlichen Demokratien. Werden Politiker die Ausbreitung des religiösen Fundamentalismus in Deutschland stoppen?

Der Kommentar suggeriert unterschwellig, Kopftuchträgerinnen seien gleichsam per definitionem intolerant und radikal, sie verachteten die Werte der westlichen $\mathrm{De}$ mokratien. Landespolitiker stimmen bereitwillig ein ins Lied der referierten vox populi und erwecken kraftmeierisch den Eindruck, mit dem beherzten Verbot des Kopftuchs in Bayern zugleich den islamischen Fundamentalismus aus der Welt schaffen zu können. So wird die Kopftuchfrage leichtfertig zum Kulturkampf emporstilisiert, zur Frage des Überlebens der bürgerlichen D emokratie, der Bedrohung durch eine radikale Glaubensgemeinschaft, die sich ihrer Integration beharrlich verweigere - schon ein „Kreuz mit dem Koran“, faßt D er Spiegel die öffentliche D ebatte mit leiser Ironie zusammen (ibid. 82):

Nach dem Urteil des Bundesverfassungsgerichts wird aus dem Streit um das Kopftuch einer muslimischen Lehrerin ein Kulturkampf: Islamisten stellen die Grundwerte der bürgerlichen Demokratie in Frage, die Integration der drittgrößten Glaubensgemeinschaft droht zu scheitern.

Dem islamischen Symbol - „Kopftuch einer muslimischen Lehrerin“- werden in ungenauer Gleichsetzung sozusagen ,islamistische’ Merkmale zugeordnet: sie bean-

${ }^{6}$ Alle Zitate im folgenden entstammen diesem Bericht und werden nur per Seitenangabe im Text zitiert: D er Spiegel 40/ 2003 v. 29.09.2003. 
spruche, „K opfhaar, O hren und Hals mit einem Q uadratmeter Stoff zu umwickeln und dann erst vor deutsche Schüler zu treten - zur Wahrung ihrer ,Würde'“ (ibid.). G efahr im Verzuge also für deutsche Kinder, die ihrer zu erwartenden Indoktrination hilflos ausgeliefert würden. D ie Anführungszeichen, auch in der dazugehörigen Bildunterschrift noch einmal zitiert, markieren ironische Distanz zu dem von ihr reklamierten Anspruch, ziehen ihn in Zweifel, als ob die Würde eines Menschen von einem „Stück Tuch“ abhinge, von einem um den Kopf gewickelten "Q uadratmeter Stoff".

Auf die für den Spiegel typische Ironie reagieren tief religiöse Menschen in der Regel konsequent humorfrei (die Leserbriefe freichristlicher Leser von kirchenkritischen Artikeln sind in ihrer gelegentlich schäumenden Diktion durchaus vergleichbar). Ironie unterminiert die Selbstgewißheit derer, die sich im Besitze ,ewiger Wahrheiten' wähnen, weshalb sie darauf so besonders gereizt reagieren (cf. Rorty 1992). Entsprechend empfindlich reagierten Muslime denn auch auf einen Bericht im Spiegel, in dem unter dem vielleicht etwas sorglosen Titel „O ben ohne“ (D er Spiegel 53/2001) über ein früheres Urteil in derselben Sache berichtet wurde, nach dem zunächst ein Verbot ergangen war. Eine muslimische Lehrerin ohne Kopftuch als Frau „oben ohne“ - schon die Vorstellung scheint für manche Muslime nur schwer verkraftbar. Sie finden sich offenbar auch nicht recht ernst genommen, wenn der Bericht (D er Spiegel 40/ 2003 v. 29.09.2003) die religiös (und politisch) aufgeladene Bedeutung des Stoffs in Frage stellt: „Viel Lärm um ein Stück Tuch?", „Lächerlicher Streit um ein textiles Symbol in einer Zeit, die andere Sorgen hat?" (ibid. 82). D as Symbol übernimmt dabei mehrere Funktionen zugleich: es ist Zeichen für Islamismus und Radikalismus, aber auch für die „religiös begründete „D egradierung der Frau'“ (ibid. 83). Die hier in Rede stehende ,degradierte Frau' erscheint freilich alles andere als demütig: „Sie wollte und will besser behandelt werden als ihre Mitbürger" (ibid.).

Ist die behauptete Wahrung ihrer ,Würde' überhaupt ihr wahrer Grund? „Immerhin leben Millionen gläubiger Musliminnen ohne Kopftuch auf der Welt", wissen die Autoren (ibid.). Sie stimmen dem Urteil der Feministin Alice Schwarzer unumwunden zu: die habe (im Spiegel 26/ 2003) bereits „überzeugend dargelegt, wie wenig tolerant Frau Ludin sich bisher geäußert“ habe, woraus folge: „Frau Ludin fordert Toleranz für die Intoleranz" (ibid. 84) - und ihr Kopftuch sei dafür das äußere Zeichen (s.o.). D abei war es der erst „,seit 1998 [... ] zum Kopftuch bekehrten Lehrerin [... ]" offenbar nicht schon immer so wichtig, sondern wurde es erst, auf je mehr Befremden ihrer Umgebung sie stieß. Frau Schwarzer weiß zu berichten: „Als Pädagogikstudentin gab sie eines Tages Männern nicht mehr die Hand, mehrfach verkündete sie, deutsche Frauen seien ,unrein', nur muslimische seien ,rein'. Dies sind keine harmlosen Prädikate“ (ibid.).

Wie wenig harmlos das Kopftuch in Wahrheit sei, wird dem Leser spätestens klar, wenn nebenbei die dunklen Assoziationen mit den Proklamationen radikaler Islamisten wie des ehemaligen Kölner „Kalifen“ und des iranischen Revolutions- 
führers Ayatollah Chomeini eingeflochten werden (die mit dem hier verhandelten Fall eigentlich in keiner mit bloßem Auge erkennbaren Verbindung stehen):

Die gestrengen Kopftuch-Fetischisten vom „Islamrat" und dem „Zentralrat der Muslime in D eutschland", mit deren Unterstützung sie ihr Recht einfordert, unterscheiden sich von den meisten in D eutschland aktiven islamischen Verbänden durch ihr merkwürdiges Verständnis vom demokratischen Rechtsstaat. Er wird so lange respektiert, bis man mächtig genug ist, ihn abzuschaffen [... ] Der selbst emannte muslimische „Kalif" Metin Kaplan bekannte einmal: „Islam und D emokratie werden niemals miteinander vereinbar sein. Wenn wir an die Macht kommen, werden wir das Parlament zerstören und niederbrennen und die Asche im Meer verstreuen [... ] Der iranische O berschiit Ajatollah Chomeini hat die Menschenrechte eine ,von Zionisten ausgedachte Regelsammlung' genannt, die ,alle wahren Religionen' zerstören wolle“ (ibid. 84).

Natürlich seien nicht alle Muslime derart finstere Figuren. Es gebe sogar ein paar Reformer, „[...] die eine Modernisierung ihrer Religion fordern und betreiben. Der ägyptische Schriftsteller Farag Ali Foda“, zum Beispiel, sei für eine radikale Modernisierung des Islams eingetreten mit dem Satz: „Uns Muslimen fehlt ein Martin Luther" (ibid.). Und der iranische G eschichtsprofessor Haschem Aghadschari habe die Mullahs immerhin mit den Worten gemahnt: „D ie Menschen sind keine Affen, die einen $\mathrm{G}$ eistlichen nachahmen müssen [... ] Was ist das für eine Religion, die Folter rechtfertigt?" (ibid.). D ie offenbar einzigen auffindbaren G egenzeugen haben typischerweise keine Chance:

Allerdings wurde Foda 1992 wegen seiner Ketzereien ermordet, und der iranische Historiker wurde verhaftet und verurteilt - 74 Peitschenhiebe, 10 Jahre Berufsverbot, 8 Jahre G efängnis und am Ende, sollte er nicht begnadigt werden, Tod durch den Strang (ibid.).

Die Verbindung zwischen der Lehrerin mit dem Kopftuch und den islamistischen Fanatikern Kaplan und Chomeini mag sachlich eher lose sein, aber sie wird assoziativ geschickt hergestellt durch den Bezug auf Alice Schwarzers Behauptung, daß Ludin deutsche Frauen als ,unrein' bezeichnet habe: „Hat sich Lehrerin Ludin von dieser Variante islamischer ,Reinheit' irgendwann hörbar distanziert? Es wurde bisher nicht bekannt" (ibid. 84).

D as düstere Islambild wird durch die für den Bericht ausgewählten Bilder und deren Untertitel gezielt ausgemalt. Dabei wird aus der D ebatte über das Kopftuch in den Schulen gleichsam unter der Hand eine Debatte über die Extremisten und deren Versuche, das Land zu unterwandern. Ein Bild von dem Islamisten Kaplan wird textuell verknüpft mit Bildern von andern Muslimen in D eutschland, die jeweils mit Leitsätzen von Extremisten oder kritischem Kommentar untertitelt werden (Abb. 8-10): 


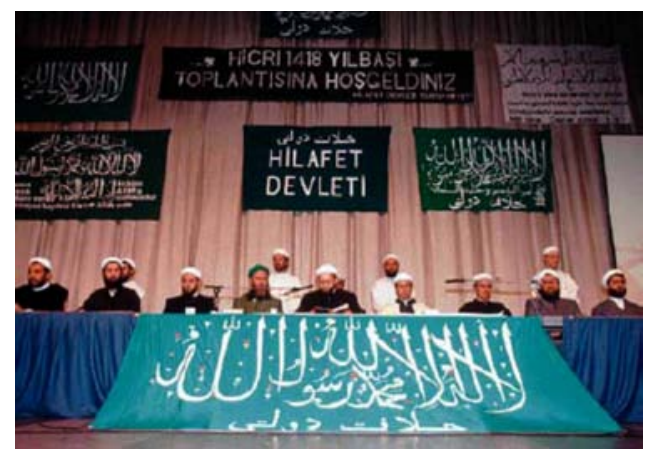

Abb. 8: Islamisten-Führer Kaplan (Mitte): „Parlament zerstören und niederbrennen“ (2001)

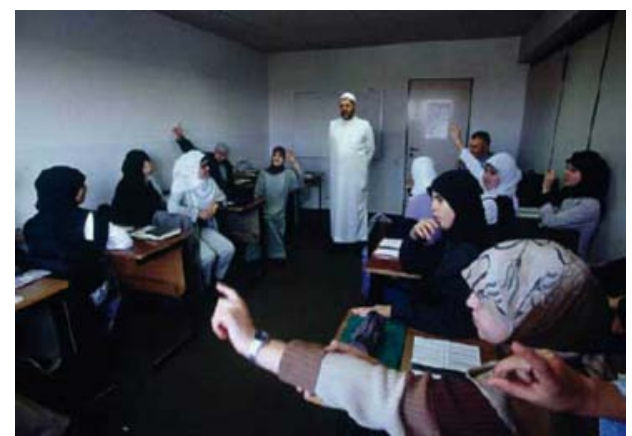

Abb. 9: Koranschule (Frankfurt am Main): „Wahre Kämpfer für den Islam“

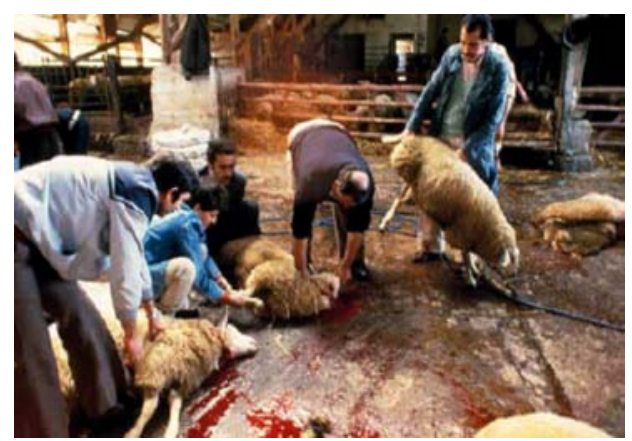

Abb. 10: Muslimisches Schächten (in Lüdenscheid): „Teilsieg vor dem Verfassungsgericht"

Die Assoziationskette ist fast unausweichlich: vom Kopftuch zum Terror ist nur ein Schritt. Kopftuch-Befürworter sind in diesem Bericht nur noch „KopftuchBekenner", „Kopftuch-Fetischisten“, „Kopftuch-Eiferer" (ibid. 83 ff.). Wer aus G ründen wie multikulturelle Offenheit, religiöse G leichbehandlung oder sogar In- 
tegration der Muslime seine Zulassung zu rechtfertigen suche, sei wie ein naiv gutgläubiger Biedermann, der die Brandstifter ins Haus hole:

Wer das Tolerieren des Tuchs auf dem Haupt der staatlich bezahlten und verbeamteten Lehrerin zum Maßstab multikultureller Offenheit, religionspolitischer Gleichbehandlung der Glaubensgemeinschaften oder gar der Fähigkeit dieser G esellschaft erhebt, Fremde zu integrieren, der unterschätzt den aggressiven Geltungsanspruch islamischer Fundamentalisten. Dieser muß nicht erst dann in die Schranken gewiesen werden, wenn er terroristisch wird (ibid. 84).

Im Vergleich zur Berichterstattung zum selben Thema vor dem 11. September 2001 ist der Ton deutlich rauer geworden. Jetzt ist „der Schleier der Frauen das Banner der islamistischen Kreuzzügler" (Schwarzer, ibid. 84). Vorher (im genannten Bericht 1998 über den Fall Ludin in der früheren Instanz) wurde der Rektor ihrer Schule, der "gläubige Katholik“ Peter Skobowsky, mit seiner freundlichen Äußerung über die Lehrerin noch eher beifällig zitiert: , ,[... ] an der Integrität von Frau Ludin habe ich keinen Zweifel“ (D er Spiegel 30/ 1998 v. 20.07.1998: 59). Sie habe den Beamteneid geleistet, sie stehe überzeugt hinter dem gesamten Lehrplan, „inklusive Sexualkunde“ (ibid.). Auch die Klägerin selber kam mit ihrer eigenen Meinung ausführlich zu Wort.

Seit 2001 dagegen tauchen auch im Spiegel im Zusammenhang mit Muslimen auffällig häufig Begriffe wie ,Kulturkampf', ,Zivilisationskonflikt', ,Religionskrieg' usw. auf: „Auf dem Schulhof der Hohbergschule im schwäbischen Plüderhausen ist der Kulturk ampf längst entschieden“, „Nach dem Urteil des Bundesverfassungsgerichts wird aus dem Streit um das Kopftuch einer muslimischen Lehrerin ein Kulturkampf“, „Für Andreas, 13, ist der ,Z ivilisationsk onflikt” („Frankfurter Allgemeine") eher eine ästhetische Frage“, „D er G laubensk rieg ums Kopftuch hat die Kranken- und Pflegestationen erreicht“, „D och G esetze gegen Kopftücher und religiöse Diskriminierung könnten einen Kulturkampf provozieren" (Zitate aus D er Spiegel 27/ 2001: 46; 40/ 2003: 82; 43/ 2003: 40; 51/ 2003: 7; Hervorh. v. Verf., EHL).

$D$ as ist keineswegs eine Besonderheit dieses Nachrichtenmagazins. Ein Blick über die Grenzen bestätigt das Bild. In ihrer Berichterstattung über das Kopftuch in Frankreich, in Deutschland oder in Österreich ist sich die Presse weitgehend einig: Das Kopftuch wird semiotisch zunehmend zum Icon eines ,cultural clash', für die einen ist es ein Zeichen für den „drohenden Vormarsch eines islamischen Fundamentalismus" und einer „ethnischen Überformung“ Europas, für die anderen die „Behauptung der eigenen nationalen Identität" und die selbstgewisse „Zurschaustellung des religiösen Bekenntnisses in einer fremden Umwelt" (D ie Presse v. 24.01.2004).

Metaphern und Collocationen (lexikalische Kookkurrenzen) indizieren, ja inszenieren die Kopftuchdebatte zunehmend als ,Kampf der Religionen': „Im glaubensstarken Freistaat [Bayern] ist die Furcht offenbar am größten, daß es mit der Verteidigung des Abendlandes in den bayerischen Klassenzimmern nicht einfach 
wird" (D er Spiegel 43/ 2003: 40). Die Leserbriefe spiegeln den dramatischen Wandel der Einstellungen nach dem historischen Wendedatum 2001 aufs Deutlichste: überwogen vorher die Stimmen für Toleranz gegenüber dem Kopftuch, sind die Kommentare jetzt mehrheitlich eindeutig für ein Verbot des Kopftuchs bei der Arbeit im Öffentlichen Dienst. Jetzt gilt es nicht mehr nur als Symbol der Unterdrückung von Frauen, sondern lädt sich semantisch auf zum Icon aller negativen Assoziationen mit dem Islam. Was vorher allenfalls als diffuser Verdacht auftauchte, erscheint heute den Lesern als gesicherte Erkenntnis: das Kopftuch ist das Symbol der Unterdrückung, der Intoleranz und des Extremismus. Wer vorher das Kopftuch trug, galt allenfalls als altmodisch, unterdrückt und unselbstständig. Wer es heute trägt, macht sich islamistischer Umtriebe verdächtig. Umgekehrt kann sich die überzeugte Kopftuchträgerin nicht mehr allein auf ihre G laubensfreiheit berufen - sie setzt heute zugleich, ob sie das will oder nicht, ein politisches Zeichen.

D as bestätigt die eingangs formulierte Feindbild-Hypothese: D em Kategorisierungsmerkmal (,Kopftuch') der damit etikettierten bzw. sich damit ausweisenden Mitglieder der Gruppe A (,alle ein Kopftuch tragenden Frauen') werden automatisch die schablonenhaften Bilder, Motive und Charakterzüge und von X (,unterdrückt/ fanatisch/ integrationsresistent/ extremistisch') zugeschrieben. Auch wer andere Erfahrungen mit Mitgliedern des A-Typs hat, kategorisiert die konkrete Person $A_{1}$ oder $A_{2}$ als $Y$ (,Ausnahme von der Regel'), während für alle andern $A_{n}$ die routinemäßige Askription $\mathrm{X}$ nicht nur nicht irritiert wird, sondern sich progredient stabilisiert.

\section{Diskussion}

„Was bedeutet ein Kopftuch?", fragt der Rechtsexperte Thomas D arnstädt in seinem Beitrag zum Spiegel Special 2/ 2008 - einem Sonderheft zum Thema D er Islam und die D eutschen - im Rückblick auf den "Glaubenskrieg um das Kopftuch" (D arnstädt 2008: 80-84). Es sei zum Fetisch geworden, so D amstädt, „zur religiösen Reizwäsche", und er resümiert die kontroversen Positionen der medialen Kopftuch-D ebatte der letzten D ekade. D ie Debatte wird allerdings nicht minder kontrovers geführt zwischen den Muslimen selbst. Die Fronten sind verhärtet. Auf der einen Seite die muslimischen Kämpferinnen, die sich wie die Lehrerinnen $\mathrm{Fe}$ reshta Ludin, D oris Graber oder Brigitte Weiß das Recht auf ihr Kopftuch durch alle Instanzen erklagen, auf der anderen Seite die aufgeklärten Muslima, die es wie die Berliner Anwältin Seyran Ates (2007) für ein „Mittel der Entmündigung“ halten: „D as Kopftuch tut zwar nicht weh, aber es bricht den freien Willen. Es installiert ein Frauenbild, das einen Bruch mit der Demokratie und der Gleichberechtigung der Geschlechter bedeutet" (Spiegel Special 2/ 2008: 82). Die muslimische Soziologin Necla Kelek wird als Mitglied der ,Islamkonferenz' des Innenministeriums dazu zitiert (ibid. 81): 
Der von den Muslimen angezettelte ,Kopftuchstreit' [ist nur Teil] eines religiöspolitischen Kampfes, der von Muslimen unter dem Schleier der Religionsfreiheit geführt wird. [... D er Islam] ist aber nicht tolerant, sondern er klagt unsere Toleranz ein, um sich selbst zu entfalten.

Noch konsequenter tritt der 2007 gegründete ,Zentralrat der Ex-Muslime' für die Trennung von Staat und Religion ein. Seine Mitglieder riskieren dabei ihr Leben, denn eine islamische Rechtsvorschrift der Scharia fordert für die Abkehr vom Glauben die Todesstrafe. Die Vorsitzende des Zentralrats, die gebürtige Iranerin Mina Ahadi, beklagt in ihrer Autobiographie (Ahadi 2008) die einseitige Zusammenarbeit politischer Instanzen mit den islamistisch geprägten Organisationen in D eutschland und die zugleich fehlende Repräsentanz der Mehrheit der gemäßigten Muslime. Sie spricht sich gegen Kopftücher in öffentlichen Behörden aus, gegen die Macho-Kultur in muslimischen Familien, für die Meinungsfreiheit und das Existenzrecht Israels. D eshalb braucht sie in D eutschland im Jahre 2008 Polizeischutz.

Überschaut man das letzte Jahrzehnt massenmedialer Thematisierung des Islam in D eutschland, so hat die quantitativ enorme Zunahme der Berichterstattung und qualitativ immer differenzierte D arstellung aller seiner Verästelungen nicht zu einer Verbesserung der Verständigung zwischen Muslimen und Nicht-Muslimen in Deutschland beigetragen. Eher im Gegenteil. Eine im Auftrag des Bundesinnenministeriums durchgeführte neue Studie der Universität Hamburg vermittelt ein differenziertes Bild der „Muslime in D eutschland“. Der Grad ihrer Zustimmung zum Kopftuch ist danach abhängig von Alter und Geschlecht (s. Abb. 11; Quelle: Spiegel Special 2/ 2008: 27 [statistisch auf $100 \%$ angepaßt und neu gezeichnet]).

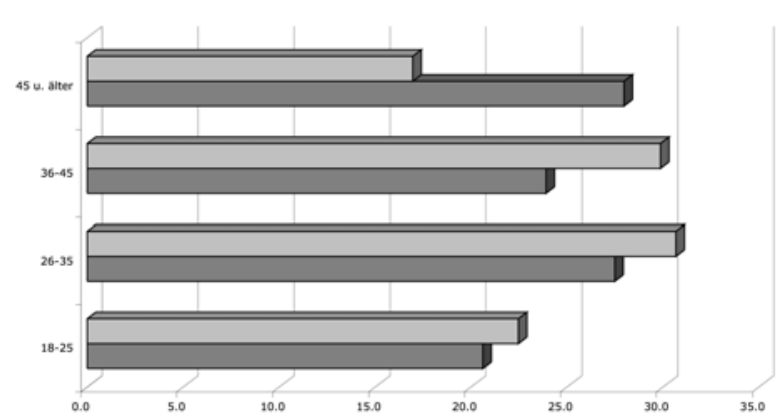

Abb. 11: Zustimmung unter Muslimen in Deutschland zur Kopftuchpflicht für Frauen (2008)
Bei den sich selbst als religiös bezeichnenden Muslimen sieht das Bild deutlich anders aus: dort befürworten gut drei Viertel der Befragten das Kopftuch und halten es für unabdingbar. Umgekehrt schätzen 83\% der Deutschen Muslime als religiöse Fanatiker ein; $61 \%$ bezweifeln, daß der Islam friedlich neben dem 
Christentum existieren kann; und gar 98\% der Deutschen verbinden den Islam mit Terror und Gewalt, nur 6\% bekunden Sympathie für den Islam (Pötzl 2008: 11). Seine Assoziation mit Fundamentalismus, Unterdrückung der Frau, Gewaltbereitschaft, Machotum, Homophobie usw. (s.o.) ist durch die tägliche Medienpräsenz in den letzten zehn Jahren nicht aufgelöst, sondern bekräftigt worden. Bekräftigt leider auch gerade von manchen Muslimen selbst, die täglich Anlässe für die negative Berichterstattung liefern. Wie soll man positiv, verständnisvoll, kulturtolerant berichten z.B. über ,Ehrenmorde' an muslimischen Mädchen, die sich in einen ,Ungläubigen' zu verlieben das Pech haben? Soll man schweigen zu homophoben Hetzkampagnen muslimischer Zeitungen, die in Berlin erscheinen und dort zum Mord an Homosexuellen aufrufen?7 Was ist von den muslimischen Verbänden zu derlei zu hören außer matten Ausflüchten und ausweichenden Gegenfragen? Die Ursachen der wachsenden Entfremdung und Re-Islamisierung zu erforschen ist dringend geboten, wenn sich das Verhältnis der drei Millionen Muslime zu ihrer Residenzgesellschaft nicht weiter verschlechtern soll.

Alarmierend sind die Erhebungen des Essener Zentrums für Türkeistudien, das seit vielen Jahren die religiöse Bindung türkischstämmiger Migranten erforscht: innerhalb nur einer D ekade vervierfachte sich der prozentuale Anteil derer, die sich als ,streng religiös' bezeichneten. Ihre Wertvorstellungen werden zunehmend von Medien der Herkunftsländer beeinflußt. Nur noch eine Minderheit verfolgt überwiegend die deutschsprachigen Medien (Fernsehen: 37,5\%; Zeitungen: 41,3\%). Bärtige Männer mit Strickmützen und Frauen in langen Mänteln und mit Kopftuch bestimmen das Straßenbild in den $\mathrm{G}$ hetto-Vierteln der $\mathrm{G}$ roßstädte. Sie fühlen sich bestärkt in ihrer Integrationsresistenz durch die Warnung des türkischen Premiers Recep Tayyip Erdogan (vor 20000 Türken in der Köln-Arena) vor zu viel Anpassung: „Assimilation ist ein Verbrechen gegen die Menschlichkeit“ (Pötzl 2008: 11).

„Wie viel Freiheit den Feinden der Freiheit?", fragt Darnstädt (2008: 84), „Wie viel Freiheit kann der säkulare Staat fremden Frommen einräumen, die in Verdacht stehen, mit ihren Maximen die hiesigen kulturellen Grundlagen zu ruinieren, wenn nicht sogar die Trennung von Staat und Kirche in Frage zu stellen?" Die teils halbherzige, teils widersprüchliche, teils unausgewogene Rechtsprechung dazu in den letzten Jahren ist offenbar nicht die geeignete Antwort. Konsequent laizistische Länder in der Europäischen Union haben es da insofern leichter, als alle wissen, woran sie sind. In Frankreich oder D änemark sind auffällige religiöse Zeichen in Schulen und Universitäten schlicht untersagt - für alle. Das Glaubensbekenntnis ist dort Privatsache. In D eutschland nicht. D as kompliziert die Dinge, je länger je

\footnotetext{
${ }^{7}$ So rief z.B. Muhammed Lujain al-Zayn im arabischen Berliner Magazin A l-Salam (April 2008) unter dem Titel „Ein fleischfressendes Bakterium und geschlechtliche Anormalität“ zur Ächtung von Homosexuellen auf, begrüßte Aids als die vom Propheten vorhergesagte gerechte Strafe und erinnerte seine Leser nachdrücklich daran, daß dieser „in mehreren Hadithen“ bekräftigt habe, „daß homosexuelle Männer zu töten seien“ (D ie W elt online v. 06.08.2008 [06.08.2008]): http:/ / www.welt.de/ berlin/ arti2290850/ Arabische_Zeitung_hetzt_in_Berlin_gegen_Homosexuelle. html
} 
mehr. Die radikalen Muslime werden das zu nutzen wissen. Solange die gemäßigten Muslime wegsehen und schweigen. Mit ihnen gilt es, das G espräch zu suchen, nicht als wechselseitig Belehrende, die ,immer schon' wissen, was des andern Wohl sei, sondern als Partner, die einander von ihren Erfahrungen erzählen, ihrer $\mathrm{Ge}$ schichte und ihren G eschichten, für den Aufbau einer „G emeinschaft des Vertrauens" zwischen ,uns' und ,den andern' (Rorty 2008).

\section{Literaturangaben}

Abu Zeid, Amr Shaker Hammad (2006): D as Bild der muslimischen A raber in den deutschen Medien vor und nach dem 11. September 2001. A nalyse ausgewählter M edientex te. Kairo: M.A.-Arbeit Al Azhar Universität.

A hadi, Mina mit Sina Vogt (2008): Ich habe abgeschworen. München: Heyne.

Ates, Seyran (2007): D er M ultikulti-Irrtum. Berlin: Ullstein.

Bundesministerium des Innern (ed.) (2008): Muslime in D eutschland. www.bmi.bund.de.

Darnstädt, Thomas (2008): „Religiöse Reizwäsche. Der Glaubenskrieg um das Kopftuch“. In: Spiegel Special 2/ 2008: 80-84.

Doelker, Christian (1997): E in Bild ist mehr als ein Bild. V isuelle Kompetenz in der M ultimedia-G esellschaft. Stuttgart: Klett Cotta.

Dönhoff, Marion Gräfin (1987): „Vom Unfug der Feindbilder. Wie sich die Mächte und die Mächtigen ihre Widersacher selbst erfinden“. In: D ie Z eit 49 v. 27.11.1987.

Eickhoff, Ekkehard (2008): V enedig, W ien und die 0 smanen. U mbruch in Südosteuropa 1645-1700. Stuttgart: Klett Cotta.

Krämer, Sabine \& Klaus-D ieter Walter (1996): Informationsmanagement. München: Knaur.

Leuenberger, Susanne (2006): „Der grüne Islam: eine semiotische Betrachtung“. In: U ni Press Bern 131/ 2006: 15.

Mast, Claudia (ed.) (81998): A BC des Journalismus. E in L eitfaden für die Redak tionsarbeit. Konstanz: UVK.

Pötzl, Norbert F. (2008): „Schatten über Almanya“. In: Spiegel Special 2/ 2008: 9-13.

Prokop, Isabela (1995): „Stereotype, Fremdbilder und Vorurteile“. In: Marek Czyżewski et al. (eds.) (1995): N ationale Selbst- und Fremdbilder im Gespräch. O pladen: Westdeutscher Verlag.

Rorty, Richard (1992): Kontingenz, Ironie und Solidarität. Frankfurt/ Main: Suhrkamp. 
Rorty, Richard (2008): Philosophie als Kulturpolitik. Frankfurt/ Main: Suhrkamp.

Rotter, Gernot (ed.) (1993): D ie W elten des Islam. N eunundzwanzig V orschläge, das U nvertraute zu verstehen. Frankfurt/ Main: Fischer.

Schaff, Adam (1980): Stereotypen und das menschliche Handeln. Wien/ München/ Zürich: Europa-Verlag.

Schiffer, Sabine (2004): Die Darstellung des Islams in der Presse. Sprache, Bilder Suggestionen. E ine A uswahl von Technik en und Beispielen. Erlangen: Diss. phil.

Spiegel Special (2/ 2008): A llah im A bendland. D er Islam und die D eutschen. Hamburg: Spiegel-Verlag.

Spillmann, Kurt R. \& Kati Spillmann (1989): Feindbilder. E ntstehung, Funktion und Möglichkeiten ihres A bbaus (= Zürcher Beiträge zur Sicherheitspolitik und Konfliktforschung 2/ 1989). Zürich: Forschungsstelle für Sicherheitspolitik und Konfliktanalyse/ Center for Security Studies (CSS) der ETH Zürich.

Stöckl, Hartmut (2004): D ie Sprache im Bild - Das Bild in der Sprache. Z ur V erknüpfung von Sprache und Bild im massenmedialen Text. Konzepte Theorien, A nalysemethoden. Berlin/ New York: de G ruyter.

Straßner, Erich (2002): Text-Bild-Kommunik ation Bild-T ext-Kommunikation. Tübingen: Niemeyer.

Strobl, Anna (1997): Islam in Österreich: eine religionssoziologische Untersuchung. Frankfurt/ Main etc.: Peter Lang.

Thofern, D etlef (1998): D arstellung des Islams in ,D er Spiegel'. E ine inhaltsanalytische U ntersuchung über Themen und Bilder der Berichterstattung von 1950-1989. Hamburg: Kovac.

Wittkämper, Gerhard W. (1992): Medien und Politik. Darmstadt: Wiss. Buchgesellschaft. 


\title{
Die Wahrnehmung des religiös Fremden: Exotik, Empathie und allengische Abwehr
}

\author{
A ndreas G rünschloß
}

\section{Einleitung}

\subsection{Hinführung zum Thema: vier einleitende Konkretisierungen}

(1) Wer unvorbereitet die Anlage des Franziskanerklosters in Dietfurt im Altmühltal erkundet, wird erstaunt darüber sein, im Innenhof des Klosters, umgeben von den Klostermauern, eine klassische Zen-Meditationshalle (Zendo) zu entdecken. Hinsichtlich der Bauweise wurde der japanische Leichtbaustil lediglich in einen etwas massiveren Ausbau transformiert, aber abgesehen davon ist der japanische Zen-Stil unverkennbar - auch ein meditativer kleiner Steingarten fehlt nicht. ${ }^{1}$ Im Inneren ist die Meditationshalle mit den üblichen Matten und Sitzkissen ausgestattet; lediglich an der Stimseite kündet ein schlichtes K reuz von dem neuen christlichen Kontext, in den diese Sitzhalle transponiert wurde. Es handelt sich hier offenkundig um die architektonische Umsetzung eines G edankens der „Inklusion“ (vgl. Grünschloß 1999: 276f.), d.h. der religionstheologischen Einsicht, dass bestimmte Elemente der zen-buddhistischen Praxis mit der christlichen Spiritualität direkt kompatibel sind - und somit Eingang in die christliche Praxis finden können.2 D as „Meditationshaus Dietfurt" bildet sogar eine ganz wesentliche Schnitt-

\footnotetext{
1 Auf der Homepage des Klosters bzw. „Meditationshauses“ stehen anschauliche Bilder und Filme bereit, die einen guten Einblick vermitteln können: www.meditationshaus-dietfurt.de.

2 D ies entspricht der im II. Vatikanischen Konzil mehrfach ausgedrückten Auffassung, dass die Konkretionen anderer Religionen durchaus so etwas wie "Strahlen der Wahrheit" enthalten können, die
} 
stelle des Klosters zur Außenwelt und hat entsprechende Kurse zu Spiritualitätsbildung im Programm (Zen, Tai Chi, Ikebana, Kontemplation, Qi G ong etc.). ${ }^{3}$ Dieses Beispiel soll stellvertretend für viele christliche Rezeptionsvorgänge asiatischer Spiritualität stehen - Rezeptionsvorgänge, die sich wie beim Zen einer exotischen Faszination oder zumindest einem positiven Angerührtsein von diesen (anders)religiösen Praxisformen verdanken. Eine derartig rezeptive Einstellung zu andersreligiösen Praxisformen und Vorstellungen ist jedoch nicht unbedingt typisch, wie das nächste Beispiel zeigt.

(2) Während einer norddeutschen Kirchenkreiskonferenz wurden vor kurzem im Vorfeld einer gemeinsamen religionstheologischen Verständigung über das Verhältnis zwischen Christentum und Islam zunächst die vorhandenen Einstellungen der anwesenden PfarrerInnen erhoben. Auf einem Poster wurden hierfür sechs Fragen mit jeweils einer Skala zwischen zwei Antwortalternativen aufgezeichnet, auf denen die eigenen Meinungen mit bunten Klebepunkten wie auf einem Kontinuum verortet werden konnten - mit folgenden Ergebnissen:
a) „ChristInnen und MuslimInnen glauben an denselben Gott: Ja - Nein“
ð Ballungen um die beiden jeweiligen Endpole mit leichter Mehrheit bei "Ja“
b) „Ich kann mit MuslimInnen zusammen beten: Ja - Nein“
ð Ballungen um die beiden Endpole mit bis zur Mitte gestreckter Mehrheit bei „Ja“
c) „Christentum und Islam stimmen in Ihrer E thik überein: Ja - Nein“
ठ leicht nach rechts zu „Nein“ verschobene Normalverteilung (ca. 25-100\% „Nein“)
d) "Christentum und Islam zwischen: Aufklärung - - Fundamentalismus"
ð D eutliche Mehrheit: Islam à Fundamentalismus / Christentum à Aufklärung
e) „Christentum und Islam zwischen: Frauenunterdrük ung - G eschlechterdemokratie"
ठ D eutliche Mehrheit: Islam à F.-Unterdrückung / Christentum à G .-D emokratie
f) „Aus meiner Sicht ist der christlich-islamische D ialog: sehr wichtig - nicht wichtig“
ð Tendenz zu „Ja“ (Streckung 100\% bis 25\%); ein dezidiertes Sondervotum „Nein“

D ie Pastor(inn)en waren (a) im Blick auf die Frage nach dem gemeinsamen Gott offenbar in zwei Lager gespalten, was sich auch (b) in der Frage nach der Möglichkeit gemeinsamen Betens abbildete (hier aber schon eher mit einer Tendenz zur Bejahung). (c) In der ethischen Dimension bildete sich fast eine Normalverteilung der Meinungen mit der Tendenz zur Affirmation der Unterschiede ab; die (d) Zuordnung von Aufklärung und Fundamentalismus bzw. (e) Frauenunterdrückung und Geschlechterdemokratie zeigte eindeutig die hier zu erwartenden stereotypisierenden Mehrheitsbildungen im Blick auf Negativassoziationen zum Islam. (f) Die abschließende Frage nach der Bedeutung des interreligiösen Dialogs wurde tendenziell zustimmend (von "Ja“ bis mittlere Unentschiedenheit) beantwortet, mit

dann von der katholischen Kirche integiert werden können. Vgl. meine kurze Charakterisierung dieser Religionstheologie ebd. 272-276.

3 Vgl. hierzu das Kursprogramm auf der Homepage (www.meditationshaus-dietfurt.de). 
einem pointierten „Nein“-Ausreißer. - Diese Momentaufnahme zeigt ein relativ deutliches und vermutlich nicht untypisches Profil christlicher Einstellungen zum Islam bei einem lokalen Pfarrkonvent, der sich offenbar zwischen einem eher liberalen und einem eher traditionalistischen Pol verteilt:4 Festhalten von Differenzen und grundsätzlichen Verständigungsproblemen auf der einen Seite - Wahrnehmung von $\mathrm{G}$ emeinsamkeiten und optimistischere Möglichkeiten der Anknüpfung auf der anderen. Es wäre spannend zu beobachten, wie sich diese Einstellungen nach einer längeren Phase tatsächlicher interreligiöser Verständigung und Begegnung verändern, differenzieren - oder womöglich weiter zementieren.

(3) Der allmähliche Wandel solcher Einstellungen erfolgt aber auch in Abhängigkeit von öffentlich-medialen Diskursen und den darin thematisierten lokalen, nationalen und globalen Ereignissen, wie sich an einigen aktuellen Grafiken des „Pew G lobal Attitudes Project“ zur Untersuchung der europaweiten Veränderung von Einstellungen gegenüber Juden und Muslimen plastisch zeigen lässt (Stand: September 2008): ${ }^{5}$

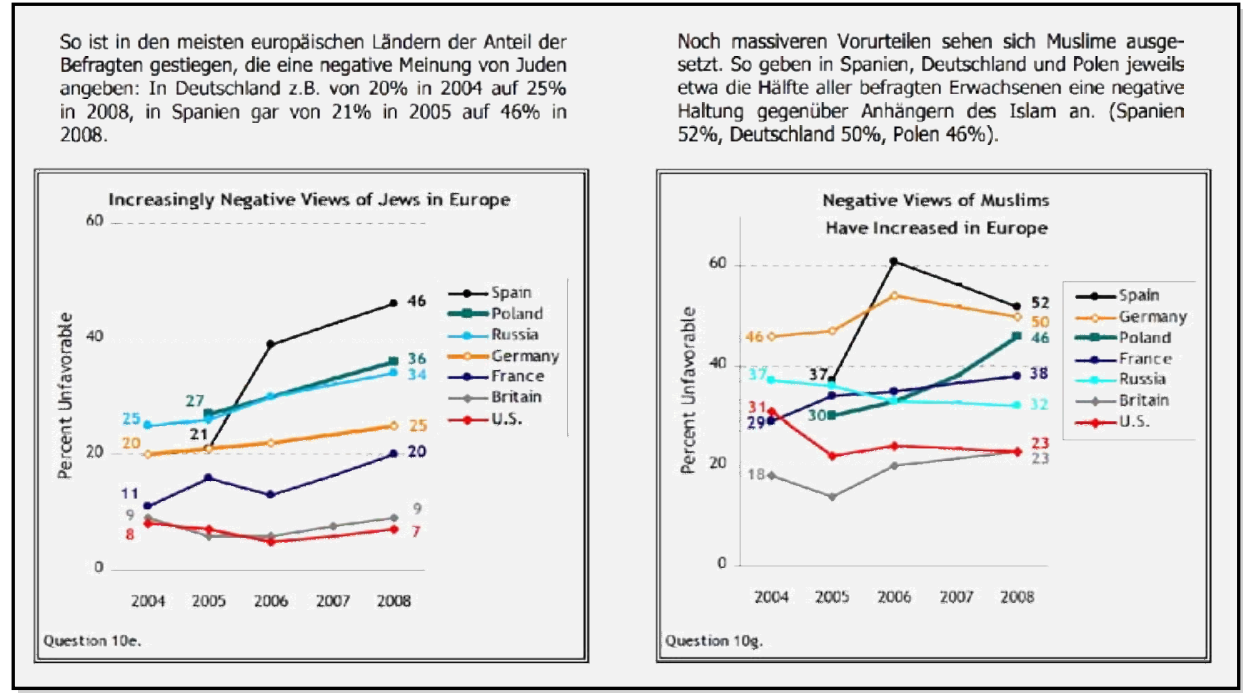

${ }^{4}$ So zumindest auch die Auskünfte, die ich zur Zusammensetzung dieser Pfarrerschaft erhielt.

5 Vgl. hierzu die knappe Darstellung auf dem Internetportal des Pew Research Centers http:/ / pewglobal.org/ reports/ display.php?ReportID =262. D ie komplette D okumentation mit dem Titel "Unfavorable Views of Jews and Muslims on the Increase in Europe“ vom 17.9.2008 kann als PD F-D atei unter der URL http:/ / pewglobal.org/ reports/ pdf/ 262.pdf heruntergeladen werden; den Hinweis darauf verdanke ich dem Blog des Religionswissenschaftlers D r. Michael Blume, dem auch die 0.a. deutschen Kommentare uber den Grafiken entnommen sind: http:/ / religionswissenschaft.twoday.net/ stories/ 5202608. 
Ich lasse die alarmierenden Negativtrends gegenüber Juden (v.a. in Kontinentaleuropa!) unkommentiert und greife nur ein paar Elemente aus der rechten Grafik heraus: Anscheinend haben die Anschläge in Spanien (2004) den Blick auf Musli$\mathrm{me}^{6}$ 2005ff. kurzzeitig massiv verändert (deutlich schwächer aber die Reaktion in England auf die Anschläge 2005), während in den USA eine von „9/11“ herrührende negative Einstellung zu Muslimen deutlich zurückgegangen ist. Manche Länder zeigen einen leichten Rückgang der antimuslimischen Einstellungen seit 2006, obwohl rund 30-50\% der Bevölkerung sehr negative Sichtweisen vertreten: vgl. v.a. D eutschland mit rund 50\% Negativeinstellungen gegenüber Muslimen!

(4) Verblüffend und zugleich erschreckend erscheint die Diffusion bestimmter Allostereotypen über interreligiös-interkulturelle $\mathrm{G}$ renzen hinweg, wie sie sich z.B. in der arabisch-muslimischen Rezeption antijüdischer und antisemitistischer Narrationen aus dem christlichen Abendland zeigt.7 Der Hisbollah-nahe libanesische Sender Al-Manar strahlte 2003-2005 eine antijüdische Spielfilmserie aus (A l-shatat, „D ie Diaspora“), in der u.a. Topoi wie die jüdische Weltverschwörung und einzelne Ritualmorde inszeniert wurden: In einer besonders grausigen Sequenz wird z.B. ein heimtückischer jüdischer Ritualmord an einem christlichen Kind gezeigt, dessen Blut in einem $\mathrm{G}$ efäß aufgefangen und dann vom Rabbi zum Backen der Pessah-Mazzen benutzt wird. ${ }^{8}$ Diese widerliche Neuauflage von religionsbezogenen Stereotypen des mittelalterlichen Judenhasses aus dem christlichen Abendland (Erb 1993; Buttaroni/ Musial 2003) dürfte in dieser bildgewaltigen filmischen Inszenierung weitaus nachhaltiger in der Lage sein als herkömmliche Printmedien, die Herzen von Menschen mit monströsen religiösen Ressentiments zu vergiften. ${ }^{9}$

\subsection{Aufgabe und Gliederung}

D amit bin ich mitten im Thema angelangt: Interreligiöse $F$ remdwahrnehmungen und die dabei zu beobachtenden interreligiösen Apperzeptions- und Austauschprozesse sind seit geraumer Zeit ein nachhaltiges Thema meines akademischen Forschens

\footnotetext{
${ }^{6}$ Am Rande sei auf ein weiteres interessantes D etail hingewiesen: Die Zustimmung zu Selbstmordattentaten ist in vielen muslimischen Bevölkerungsanteilen der Welt seit 2002 radikal zurückgegangen (vgl. in der PDF-D atei des PewResearch-Berichts, ebd. S.4: „Muslim Views on Terrorism“). - Vgl. dagegen auf der terroristischen Seite die hochgradig religiös-rituelle Kodierung der A ttentate von " $9 / 11^{\prime \prime}$, die der ausführlich kommentierten Textausgabe von Kippenberg/ Seidenstücker (2004) plastisch zu entnehmen ist.

7 Vgl. insgesamt die knappen, aber gut zugänglichen historischen Überblicke bei Küntzel (2003).

8 Ausschnitte aus dem Programm können über „Memri TV“ im Internet eingesehen werden: Die URL für diesen Filmclip ist http:/ / www.memritv.org/ clip/ en/ 895.htm; sollte der Clip so nicht mehr abrufbar sein, hilft die Suche auf memritv.org nach „Al-shatat" weiter.

${ }_{9}^{9}$ Weniger überzeugend waren die plakativen Versuche seitens der Scientology-Kirche, den öffentlichen ,G efahrendiskurs' bezüglich Scientology in den Medien insgesamt als eine transformierte Neuauflage von diskursiven Konventionen aus der antisemitischen nationalsozialistischen HetzPropaganda darzustellen: Church of Scientology International (1993).
} 
geworden. ${ }^{10}$ Im Folgenden geht es mir daher um die religiösen Absorptions- und Apperzeptionsprozesse, Verständigungs- und Systematisierungsversuche innerhalb einer religiösen Tradition, die jeweiligen $\mathrm{G}$ renzen zum religiös Anderen zu formulieren und Formen legitimer und illegitimer $\mathrm{G}$ renzüberschreitungen oder Aspekte der möglichen Inkorporation fremdreligiösen Materials zu klären und (ausdrücklich bzw. stillschweigend) zu lösen: narrative, materiale, symbolische oder konzeptionelle Konstruktionen also, mit denen eine faktisch vorhandene oder theoretisch konstruierte religiöse Pluralität erfasst, angesprochen und bewältigt wird. Solche diskursiven Vorgänge lassen sich nicht nur beobachten und empirisch beschreiben, sondern auch vergleichen, klassifizieren und analytisch ordnen. - In meinem Beitrag werden sich daher systematische Bobachtungen bzw. theoretisch-modellhafte Analysen mit konkreten, illustrativen Fallbeispielen abwechseln. ${ }^{11}$

ReligionswissenschaftlerInnen sind an die ernüchternde empirische Einsicht gewöhnt, dass es in vielen Religionen - ihrem jeweiligen Wahrheits- und Selbstverständnis entsprechend - meistens nur sehr wenig Spielräume für die W ahrnehmung einer echten religiösen A lterität gibt. D as religiös „Andere" und "Fremde“ wird innerhalb religiöser Perspektiven selten in seiner eigenen Valenz gewürdigt; faktisch überwiegen daher apologetische und polemische Methoden, das Fremde „abzuwickeln“ und ideologisch-rational zu „entsorgen" 12 - obwohl es parallel und gegenläufig dazu mitunter auch ethische Ideale interreligiöser Toleranz geben kann.13 Trotz dieses weithin herrschenden A bgrenzungsparadigmas innerhalb religiöser D iskursgemeinschaften haben die darin beteiligten Menschen faktisch immer wieder bestimmte Elemente aus anderen Traditionen positiv wahrgenommen, sie transformierend übernommen, stillschweigend in das Eigene eingebaut oder unter der Hand funktionale oder inhaltliche Âquivalente ausgebildet. Analoges geschieht bei der religiösen Überformung von autochthonen Religionskulturen durch missionarisch erfolgreiche Eroberungsreligionen: Ein mehrdimensionales Geben und Nehmen zwischen überlagernden (neuen) und autochthonen (alten) Traditionen bahnt sich hier an. Eine dezidierte $\mathrm{V}$ erständigung über die betreffenden (inkorporierten) religiösen Elemente wird seltener gesucht, und entsprechend explizite „Dialog"-Versuche sind meist an besondere historische Anlässe oder hierfür förderliche (pluralitätsoffene) Lebenskontexte geknüpft.

Sind Religionen mit ihrer deutlichen Tendenz zu Exklusivismus oder (maximal) Inklusivismus dann überhaupt in der Lage, so etwas wie eine interreligiöse Empathiefähigkeit auszubilden? Können religiöse Menschen auf D auer - auch nach besserem „Verstehen“ - die religiöse A ndersheit des religiös Fremden ertragen? - Auch

\footnotetext{
10 Vgl. v.a. Grünschloß (1999), oder „Buddhist-Christian Relationships“, in: Schmidt-Leukel (2008) Vgl. insgesamt das Literaturverzeichnis www.gwdg.de/ agruens/ Publ_agruens.pdf.

$11 \mathrm{Vgl}$. in relativ knapper Form bereits G rünschloß (2002).

12 V gl. bereits G rünschloß (1999) („Zur Phänomenologie religiöser Alterität“).

13 Dies lässt sich an frühen Konkretionen des Buddhismus gut aufzeigen, da die stramm exklusive Haltung gegenüber anderen ,Wegen' (gleichsam: ex tra sarigham nulla salus) mit ethischen Appellen der Zurückhaltung und Mäßigung in interreligiöser Begegnungen einhergeht.
} 
die zunächst scheinbar wohlwollenden Formen religiöser E x otik, sei es die abendländische Faszination des Buddhismus oder des Asiatisch-Spirituellen überhaupt oder die romantische Konstruktion eines ökologisch-religiösen Indianerbildes (sog. „Naturreligion") - auch sie liefern nur verzerrt angeeignete Bilder das Anderen, und solche Exotismen können daher ebenfalls schnell an der faktischen Realität, an der Widerständigkeit und offenkundigen Andersartigkeit der anvisierten anderen Tradition zerbrechen. Liegt für religiöse D eutungsformen also nicht ohnehin, wie bereits erwähnt, die weltweit verbreitete allergische Abwehr des andersreligiösen Weltbildes, des fremdreligiösen Lebensentwurfs und seiner darin enthaltenen ethischen und rituellen Konkretionen viel näher?

Es ist nicht möglich, diese Fragen pauschal zu beantworten. Im Folgenden werde ich einige ausgewählte Beispiele besprechen, wie religiöse Traditionen mit dem religiös Fremden, mit der religiösen Alterität umgehen, wie sie diese Wahrnehmung faktischer religiöser Pluralität konzeptionell und diskursiv verarbeiten, und zwar zwischen den beiden Polen A ttraktion und A llergiel A bwehr. - Ich werde so vorgehen, dass ich in drei Abschnitten empirische Beispielkonkretionen vorstelle und daran jeweils systematische Überlegungen grundsätzlicher Art anschließe. Am Ende des Beitrags sollten somit wichtige Strukturen und Probleme solcher interreligiöser Wahrnehmungen und diskursiven Konstruktionen anderen Glaubens anschaulich deutlich geworden sein.

\section{Entfaltung: Fallbeispiele und systematische Überlegungen}

\subsection{Fallbeispiel I - Die Bahá'í-Religion als organisierter Inklusivismus}

Die im Kontext des persischen messianisch-mystischen Islams schiitischer Prägung entstandene Religionsgemeinschaft der Bahá'í, die sich gerne als „jüngste Weltreligion" 14 bezeichnet, ist von einem offenbarungsgeschichtlichen Denken geprägt, das - in erkennbarer Anlehnung an das koranische Prophetismus-Schema - die Religionsgeschichte als eine Abfolge prophetischer Offenbarungen versteht: Die göttlichen Dispensationen ,erziehen' die Menschheit hierbei sukzes-

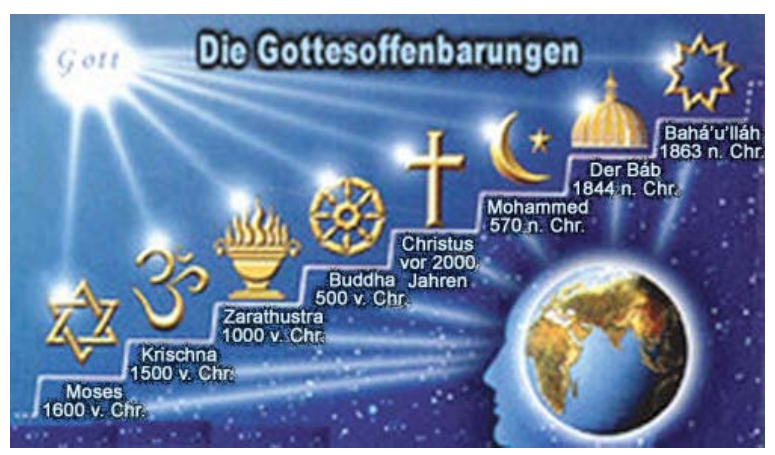

$14 \mathrm{Vgl}$. z.B. die Internetauftritte: www.bahai.de/ bahai-religion/ faq/ bahai-was-ist-das/ oder www.9-b19.de, international www.bahai.org/ faq/ facts/ bahai faith, sowie die Selbstdarstellung von Towfigh/ Enayati (2005). 
sive zu größerer Gottesnähe und ,heben' damit das religiöse Bewusstsein Stufe um Stufe an. Die Religionsstifter und Propheten der anderen Religionen repräsentieren in dieser Schau eine „Kette aufeinanderfolgender Religionen“ und sind damit Vorläufer des von Bahá'u'lláh gestifteten Bahai-Glaubens, der die derzeit höchste religiöse Realisationsform verspricht, denn „die Lehren von Gottesboten wie Moses, Christus, Muhammad oder Baháu'lláh [bauen] aufein-ander auf. - Das Ziel aller Religionen ist es, eine ,ständige fortschreitende Kultur voranzutragen'." (Towfigh/ Enayati 2005: 14f.). O der anders gesagt, der eine Gott hinter allen Religionen widmet sich einer "phasenspezifischen göttlichen Erziehung der Menschheit"15, die auch in der abgebildeten Internet-Illustration sehr gut zum Ausdruck kommt: Historisch verhalten sich die einzelnen $\mathrm{O}$ ffenbarungen $\mathrm{G}$ ottes wie aufeinanderfolgende Stufen der götlichen E rziehung in unterschiedlicher Anpassung an den jeweiligen Kontext, aber ,hinter' bzw. ,über' ihnen steht die eine transzendente Gottheit, durch die eine wesensmäßige $\mathrm{E}$ inheit aller $\mathrm{G}$ ottesoffenbarungen garantiert wird. - Dadurch kommt es zu einer sukzessiven temporalen ,Aufhebung' der einzelnen Religionen in Stufen. Diese impliziert eine Relativierung des „veränderlichen Teils“ der jeweiligen Vorläuferreligion - abgesehen von jenem „unveränderlichen Teil“ der Religion, der aus der Zentralperspektive der Bahá'í im Sinne einer Wesensbestimmung definiert wird (vgl. Towfigh/ Enayati 2005: 14f.) (wobei auch konsequent der eigene historische ,Religionsverfall' in der Zukunft einkalkuliert ist, wenn dereinst zur „Erneuerung“ der Religion wieder eine neue Offenbarung erfolgen muss). 'A bdu'l-Bahá, der erste Nachfolger des Gründers, kann daher feststellen:

Die Bahá'i-Sache ist eine inklusive Bewegung: Die Lehren aller Religionen und Gesellschaften werden hier gefunden; die Christen, Juden, Buddhisten, Mohammedaner, Zoroastrier, Theosophen, Freimaurer, Spiritualisten u.a. finden ihre höchsten Ziele in dieser Sache. ${ }^{16}$

Dieser objektsprachliche Verweis auf den Inklusivismus ist systematisch völlig stimmig: Die religionstheologische Argumentation der Bahá'í kombiniert eine hie rarchisierend-inklusive Relationierung (und zwar in temporalen Kategorien) gegenüber anderen Religionen mit einer essentiellen Identifikation des ihnen allen gemeinsamen Wesens. Es obliegt der jeweils jüngsten Offenbarung, das zeitlich ,Überholte' in den vorausgehenden genauer bestimmen zu können, um somit Essentielles und A kzidentielles in der Erziehung der Menschheit - bzw. in der kumulativen globalen ,Therapie' des göttlichen "Arztes" - voneinander zu unterscheiden:

Wisse und sei darin sicher, dass das Wesen aller Propheten Gottes eines und dasselbe ist. Ihre Einheit ist absolut. Gott, der Schöpfer spricht: Es gibt keinerlei Unterschiede zwischen den Trägem meiner Botschaft. Sie alle haben nur ein Ziel, ihr Geheimnis ist das gleiche. [...] Jeder wahre Prophet hat Seine Botschaft als wesensgleich mit der Of-

15 Siehe www.9-b-19.de/ bahai/ fortschreitende-gottesoffenbarung.php; die 0.a. Abbildung stammt ebenfalls von dieser Seite.

16 'Abdu'l-Bahá (1914); zitiert nach Figl (1993: 87f.). 
fenbarung jedes anderen ihm vorangegangenen Propheten angesehen. [...]

Die Propheten Gottes sollen als Ârzte angesehen werden, deren Aufgabe es ist, das Wohlergehen der Welt und ihrer Völker zu fördern, damit sie durch den Geist der Einheit das Siechtum einer entzweiten Menschheit zu heilen vermögen. [...] Was Wunder, wenn die von dem Arzt verordnete Behandlung an diesem Tag nicht dieselbe ist wie die, die er früher verordnet hat. Wie könnte es anders sein, wenn die Übel, die den Leidenden befallen, in jedem Stadium der Krankheit ein anderes Heilmittel erfordern. ${ }^{17}$

Aus der Bahá'í-Perspektive gilt daher im Blick auf Christ(inn)en trotz der Aufforderung zum „Kirchenaustritt" - als Verlassen der offenbarungsgeschichtlich im wahrsten Sinne des Wortes, überholten’ Institution: „Jeder Bahá'í ist zugleich auch Christ, weil er Christus und dessen geistige Botschaft anerkennt." 18 Diese religionstheologische Haltung eines grundlegenden Inklusivismus, demzufolge die Religionen im doppelten Sinn ,aufgehoben' sind, ist konstitutiv für die ganze Bahá'í- Tradition ${ }^{19}$ und hat z.B. auch in den Bahà'i-, Häusern der Andacht" architektonische Gestalt angenommen: Ihre neun ${ }^{20}$ Tore symbolisieren den umfassenden Einschluss sämtlicher Religionen, die durch diese Türen in das Bahá'i-Zentrum strömen sollen.

D ie k onzeptionelle inklusive Verhältnisbestimmung aus der D efinitionsmacht des Bahá'i-Zentrums erlaubt aber auch selek tive materiale A nleihen bei den andersreligiösen Traditionen, sofern diese eben nicht nur akzidentielle Besonderheiten (i.e.: Abweichungen), sondern essentiell Gültiges (de facto: mögliche Ü bereinstimmungen mit der Bahá'i-Tradition) transportieren. Daraus speist sich dann der selektive Zugriff auf Schriften unterschiedlichster Religionstraditionen, die in den Wortgottesdiensten der Bahá'í integriert und abschnittweise neben anderen verlesen werden können. - Die inklusive Verhältnisbestimmung (Relationierung) zwischen den religiösen Systemen fungiert hier als plausible Ermächtigungsgrundlage für diverse materiale Anleihen bei anderen Religion im Sinne additiv-synkretistischer Aneignungen - obwohl man auch umgekehrt von religionsgeschichtlichen ,Enteignungen' sprechen könnte (da das Spezielle, die historischen Konkretion der jeweiligen Alterität neutralisiert und unter die hegemoniale Dominanz des Bahá'íD iskurses gestellt wird, der gemäß seiner Figur der Selbstreferenz nur das gelten lässt, was dem eigenen Offenbarungs-Bild korrespondiert21). - D amit habe ich bereits auf die Begrifflichkeit zur eingehenden systematischen Analyse der interreligi-

17 Zit. nach der Selbstdarstellung (o.V.): Die Bahá'í-Religion (1992: 10f.).; vgl. die ältere Übers. in Effendi (31980: 56f.).

18 Vgl. www.9-b-19.de/ bahai/ fortschreitende-gottesoffenbarung.php (unter „Kirchenaustritt"); die Seite enthält darüber hinaus eine weitere illustrative Grafik zu Essenz und Akzidenz der Religionen (vgl. „D ie beiden Bereiche einer Religion bei fortschreitender O ffenbarung“).

19 Vgl. Figl (1993) sowie Hutter (1994: v.a. 45-48); vgl. jetzt auch umfassender ders. (2009).

${ }^{20}$ Als höchster Wert einer einzelnen Ziffer steht die Neun für das ,Umfassende'.

21 M. Hutter (1994: 47) weist z.B. angesichts des typischen O szillierens zwischen inklusiven und exklusiven G eltungsbehauptungen bei den Bahá'í darauf hin, „dass die Rede von der Einheit letztlich eine verschleierte Form einer Ausschließlichkeit darstellt". 
ösen Beziehungs-Dynamik in konzeptioneller Hinsicht (Relationierung) und materialer Hinsicht (Synkretismus) vorgegriffen, die im folgenden Abschnitt zu erläutern ist.

\subsection{Systematische Z wischenüberlegung I - Ein Tableau interreligiöser Verhältnisbestimmungen und materialer Anleihe}

Ulrich Berner hat bereits 1979-1982 differenzierte Überlegungen zur Neufassung der Synkretismus-Terminologie vorgelegt, ${ }^{22}$ die sich weitestgehend bewährt haben ${ }^{23}$ und für die hier anstehenden Fragen interreligiöser Dynamik fruchtbar zu machen sind. ${ }^{24}$ Ich kann hier nur die grundlegende Systematik meiner Weiterführung entfalten und verweise ansonsten auf meine ausführlichere D arstellung25. Religionsgeschichtliche Veränderungsprozesse können a) mit rein systeminternen Modifikationen einhergehen (Intensivierung) oder b) durch Beziehungen nach ,außen' bedingt sein bzw. mit solchen Entgrenzungen einhergehen (E x tensivierung).

(a) Betrachtet man die intensivierenden Prozesse, so lassen sich diese leicht in einem kontinuierlichen Spektrum von völliger Auslöschung (Extinktion), unveränderter Beibehaltung (Repristination) über umgestaltende Rekombination, Reinterpretation und Reformation bis hin zur Erfindung von Neuem (Evolution) eintragen (vgl. nachstehende Übersicht: linke Spalte).

(b) Bei den ex tensivierenden Entgrenzungsvorgängen wäre zunächst zwischen (1) konzeptionellen Verhältnisbestimmungen in theoretisch-ideologischer Hinsicht (Relationierungen) und (2) der tatsächlichen Übernahme fremden Materials (Synkre tismus) zu unterscheiden. D iese Unterscheidung ist wichtig, da vielfach ein ungenauer Sprachgebrauch hinsichtlich der Begriffs "Inklusivismus" vorherrscht, der sowohl eine hierarchische Verhältnisbestimmung gegenüber dem Anderen (vgl. das obige Stufenmodell der Bahá'í), als auch eine materiale Übernahme von Elementen und Praktiken aus anderen Traditionen meinen kann (faktische ,Inklusion' fremdreligiösen Materials; z.B. die selektive Verwendung andersreligiöser Schriften im Bahá'i-Beispiel). D er Begriff „Inklusivismus“ sollte jedoch für die rein konzeptionelle Relationierung im hierarchisch-superioren $\mathrm{G}$ estus reserviert werden, während im anderen Fall von „Synkretismus" oder, wenn man so möchte, von einzelnen „materialen Inklusionen“ zu sprechen wäre. ${ }^{26}$ - Die konzeptionellen Gattungen der Relationierung lassen sich in die drei wesentlichen $\mathrm{G}$ eltungsbehauptungen der

\footnotetext{
22 Der erste, komprimierte Aufsatz zum Synkretismus-Modell in Berner (1979) fand auch Eingang in die umfangreichere Analyse von ders., Untersuchungen zur Verwendung des Synkretismus-Begriffes (GOF.G 2), Wiesbaden 1982 (hier: 95-109).

23 Vgl. Colpe (1987). Abgesehen von dem vier Felder-perspektivischen Rotationsprinzip lassen sich auch viele der Kategorisierungen von Feldtkellers Alternativentwurf wieder in Berners Kategorien zurückübersetzen; vgl. Feldtkeller (1992/ 1993/ 1994) - Vgl. zur Diskussion von Feldtkellers Alternativen Grünschloß (1999: 54-63).

24 Vgl. insgesamt G rünschloß (1999: 44-86); die detaillierte D arstellung von Berners Modell wird 4454 entfaltet (inkl. grafische Übersicht 53).

25 Ebd., 44-86; vgl. zur Ertragssicherung 80- 85 (inkl. Übersichtsgrafik 82f.).

${ }^{26}$ Vgl. zu diesen Problemen insgesamt ebd., 77-80.
} 
D istanzierung, der Hierarchisierung und der Harmonisierung unterteilen: Sie spiegeln exakt die etablierte tripolare Klassifikation religionstheologischer Modelle in E x klusivismus, Ink lusivismus und Pluralismus.

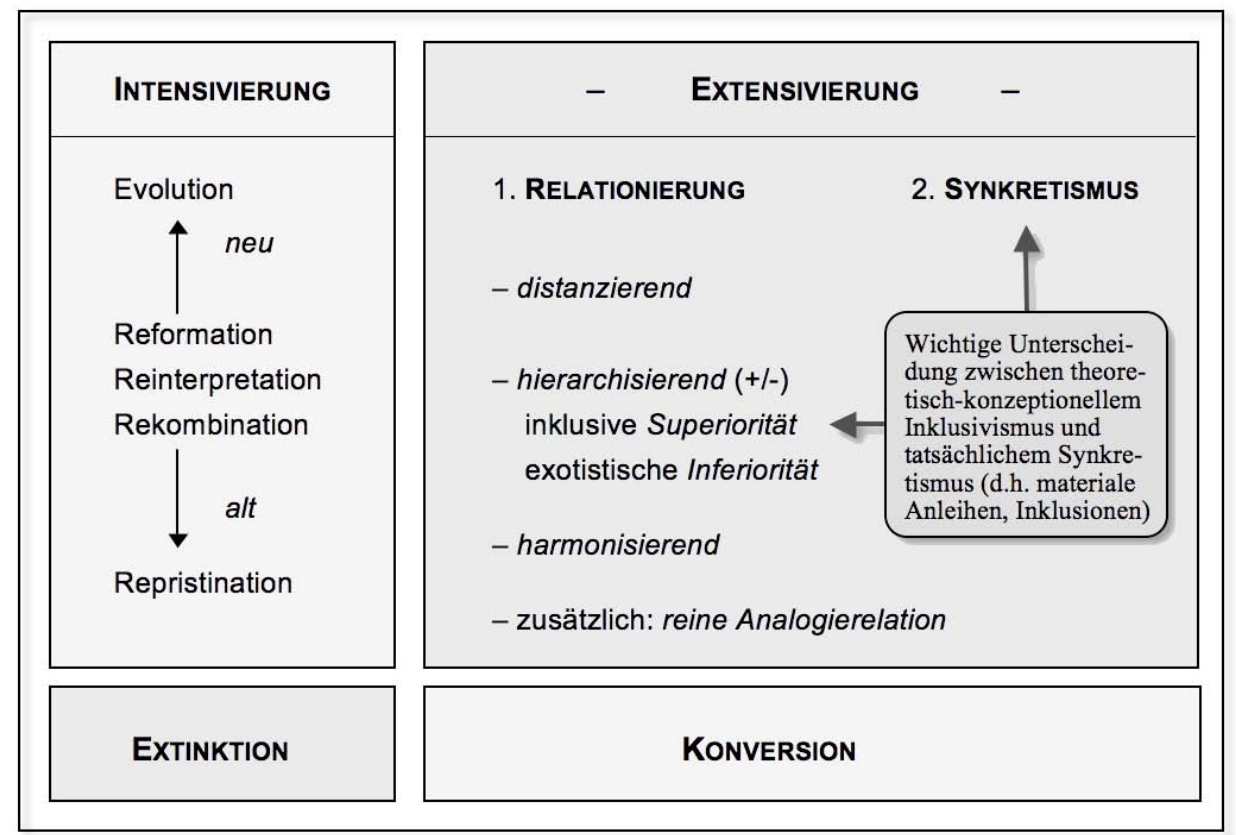

Eine feine D ifferenzierung ist jedoch anzubringen: a) hierarchisierende Relationierungen müssen nicht nur negativ akzentuiert sein, also mit einem Überlegenheitsanspruch gegenüber dem Anderen auftreten, sie können ebenso gut positive Bezugnahmen auf das Andere enthalten und in diesem Sinne ex otisierende - oder gar massiv ex otistische - Aussagen über das Andere machen (also mehr als nur harmonisierend sein). In religionstheologischen Stellungnahmen gegenüber anderen Religionen als Ganze mag dies zwar selten vorkommen (außer im Vorfeld einer individuellen Konversion), hinsichtlich einzelner Elemente oder Teilsysteme des religiös Anderen sind solche Figuren der Reverenz jedoch religionsgeschichtlich durchaus häufig. - b) D ie zusätzlich eingetragene K ategorie A nalogierelation verdankt sich der Einsicht, dass neben den drei anderen Relationierungen auch die (eher deskriptive) Feststellung einer grundsätzlichen Ä hnlichk eit erfolgen kann, und zwar noch ohne eine dezidierte Weiterverarbeitung im Sinne exklusiver, inklusiver/ exotischer oder harmonisierender Stellungnahmen - denn solche Ähnlichkeitsfeststellungen kön- 
nen ganz unterschiedliche Verarbeitungsmuster generieren oder provozieren. ${ }^{27}$ c) Eine weitere, empirisch naheliegende Relationierungskategorie wäre zudem das offenkundige $\mathrm{V}$ erschweigen - formal also eine betonte $\mathrm{N}$ ichtthematisierung des religiös $\mathrm{A} \mathrm{n}$ deren, die in vielen Fällen deutlich zutage treten kann: Diese ,Nicht-Relationierung' wäre in der 0.a. Übersicht gleichsam als eine zusätzliche, aber explizite ,Nullstelle' abzubilden. ${ }^{28}$ d) D ie Konversion markiert den extensivierenden Extremfall, bei dem das ganze eigene System weitgehend in den Bann einer distanzierenden Relationierung gestellt wird und dafür eine hoch positive O rientierung zum neuen System hin erfolgt.

Mit dieser Tafel der Möglichkeiten lässt sich bereits eine grundlegende $\mathrm{G}$ rammatik des Zusammenspiels intensivierender und extensivierender Strategien entwerfen: F undamentalismus (als religiöse Reaktionsform auf bestimmte, als traditionszersetzend wahrgenommene Auswirkungen der Moderne) ${ }^{29}$ ließe sich beispielsweise als eine selektive Intensivierung und Rekombination bestimmter fundamentals darstellen, die mit distanzierenden Relationierungen zu anderen (falschen) Religionsdeutungen einhergehen (Identifikation des Feindes: z.B. Abtreibungskliniken, Evolutionslehre sowie ,liberale' Strömungen in der Muttertradition), aber auch mit hierarchisierenden oder gar harmonischen Relationierungen zu bestimmten ,ungefährlichen', guten Aspekten der Modeme (einzelne Technologien, Kommunikationsmittel). In der Praxis können sich damit sogar innovative Elemente verbinden wie z.B. bei der ,Erfindung' der jüngsten Göttin des Hindu-Pantheons, der Bhäratmātā („Mutter Indien“), die bei Hindu-Nationalisten als die fundamentale personale Verkörperung einer primordialen nationalen und religiösen Einheit fungiert - von ,außen' betrachtet aber als sehr neu identifizierbar bleibt.

Hier wird bereits deutlich, dass man Berner darin folgen sollte, klarer zwischen den Beziehungen auf Systemebene und den Beziehungen auf E lementebene zu unterscheiden. Dadurch wird die o.a. Tafel nahezu vollständig verdoppelt (s.u.). Auf diese Weise bietet sich aber eine sehr differenzierte Möglichkeit des heuristischen Erkenntnisgewinns: Religionstheologische Relationierungen können sich nämlich sowohl auf k onk urrierende R eligionen als $\mathrm{G}$ anze beziehen oder nur auf bestimmte $\mathrm{T}$ eile daraus. Nur diese Unterscheidung von System- und Elementebene wird der Komplexität religionsgeschichtlicher Sachverhalte gerecht, da religiöse Positionen häufig mit ganz unterschiedlichen Verhältnisbestimmungen zu je einzelnen Teilen oder Elementen (bzw. Subsystemen) einer anderen Tradition operieren - die sogar in ihrer Wertung inhaltlich gegenläufig sein können: d.h., ein Element wird harmonisierend wahrgenommen, ein anderes distanzierend und wieder andere in hierarchisierender Weise (usw.). Das hat das obige Beispiel des Fundamentalismus bereits zeigen können. -

27 Vgl. das u.a. Beispiel in 2.5 und zur Begründung der Kategorie ebd. 70- 72 (D efinition: 72).

28 D en Hinweis auf diese sinnvolle Ergänzung des Schemas verdanke ich Sven Wortmann.

29 Vgl. hierzu den Auswertungsband 5 des umfangreichen Fundamentalism Project, Marty/ Appleby (1995); sowie meine D arstellung der Ergebnisse (2009: 163-196). 
Auf diese Weise lässt sich ein komplexes Modell der konkreten Beziehungsgrammatik nachzeichnen.

$\mathrm{Zu}$ diesen Relationierungen können aber auch noch einzelne materiale A bsorptionsprozesse auf Elementebene hinzutreten („Synkretismus auf Elementebene“ gemäß Berner), mit denen in Übereinstimmung mit den inhaltlichen Relationierungen - oder auch ganz gegenläufig dazu - einzelne synkretistische Anleihen beim religiös Anderen gemacht werden: Diese können additiv ausfallen (wie die Textselektionen im obigen Beispiel der Bahá'í-Religion) oder das Material wird intern selbstreferentiell weiterverarbeitet: absorbierend, transformierend und umfunk tionierend. 30 Versteckte Anleihen bieten außerdem die äquivalentierenden Bezugnahmen des Synkretismus auf Elementebene, bei denen scheinbar ganz ,eigene' Elemente ausgebildet werden, die sich aber als Äquivalente für besonders imponierend oder attraktiv erscheinende Elemente des fremden Systems erklären lassen (das auf Systemebene u.U. gar nicht eigens angesprochen, sondern ganz verschwiegen - oder womöglich sogar negativ thematisiert - wird). Viele heutige Formen christlicher Schweigemeditation und Kontemplation lassen sich vor dem Hintergrund der Zen-Rezeption beispielsweise als äquivalentierender Synk retismus auf E lementebene erkennen. ${ }^{31}$ Vor allem in der katholischen Tradition wären solche Anverwandlungen in Kongruenz mit der Konzilserklärung N ostra A etate (VAT II) zu verstehen, die eine grundsätzliche hierarchisch-inklusive Relationierung zu anderen Religions- und Spiritualitätsformen formuliert und damit (legitime) materiale Anleihen möglich macht.32

Wichtig ist auch festzuhalten, dass manche religiöse Positionen eine epistemologische U nzugänglichk eit des religiös Anderen betonen (d.h., es ist keine positive oder negative Aussage möglich), oder die Posititionsbestimmung wird im Modus reiner M odalität chiffriert - d.h., es kann nur festgehalten werden, dass es möglich ist, dass Religion x (oder ein Element daraus) in diesem oder jenem Verhältnis zu Religion y (oder einem Element daraus) hinsichtlich der Wahrheits- oder Heilsfrage zu stehen kommt - es kann aber auch nicht zutreffend sein.33

30 Vgl. hierzu die Erläuterungen bei Berner (1982: 101-105), sowie meine ausführliche Analyse (2009: 69-75).

31 Bei einer pastoralen Fortbildung wurde meine Frau Zeugin eines denkwürdigen Vorfalls: Die meditative Andacht wurde u.a. mit einem G lockensignal begonnen und beendet, und man saß aufrecht auf flachen Kissen schweigend am Boden. Als meine Frau hinterher anmerkte, die ganze Form erinnere sie sehr stark an typische Zen-Vorbilder, wurde ihr sofort von mehreren Kolleg(inn)en nachdrücklich versichert, es handle sich hier um eine ganz authentische und traditionelle Form christlicher Spiritualität.

$32 \mathrm{Vgl}$. hierzu das plakative Beispiel von der baulichen ,Inklusion' einer Zen-Halle im Franziskanerkloster Dietfurt im Altmühltal: www.meditationshaus-dietfurt.de (mit sehr anschaulichen Medien); vgl. auch Grünschloß (1999: 272-277).

33 Vgl. ebd., 38f. zur modallogischen Erfassung dieser Relationierung. Solche Positionen epistemologischer U nzugänglichk eit und reiner M odalität sprengen das o.a. Schema. 


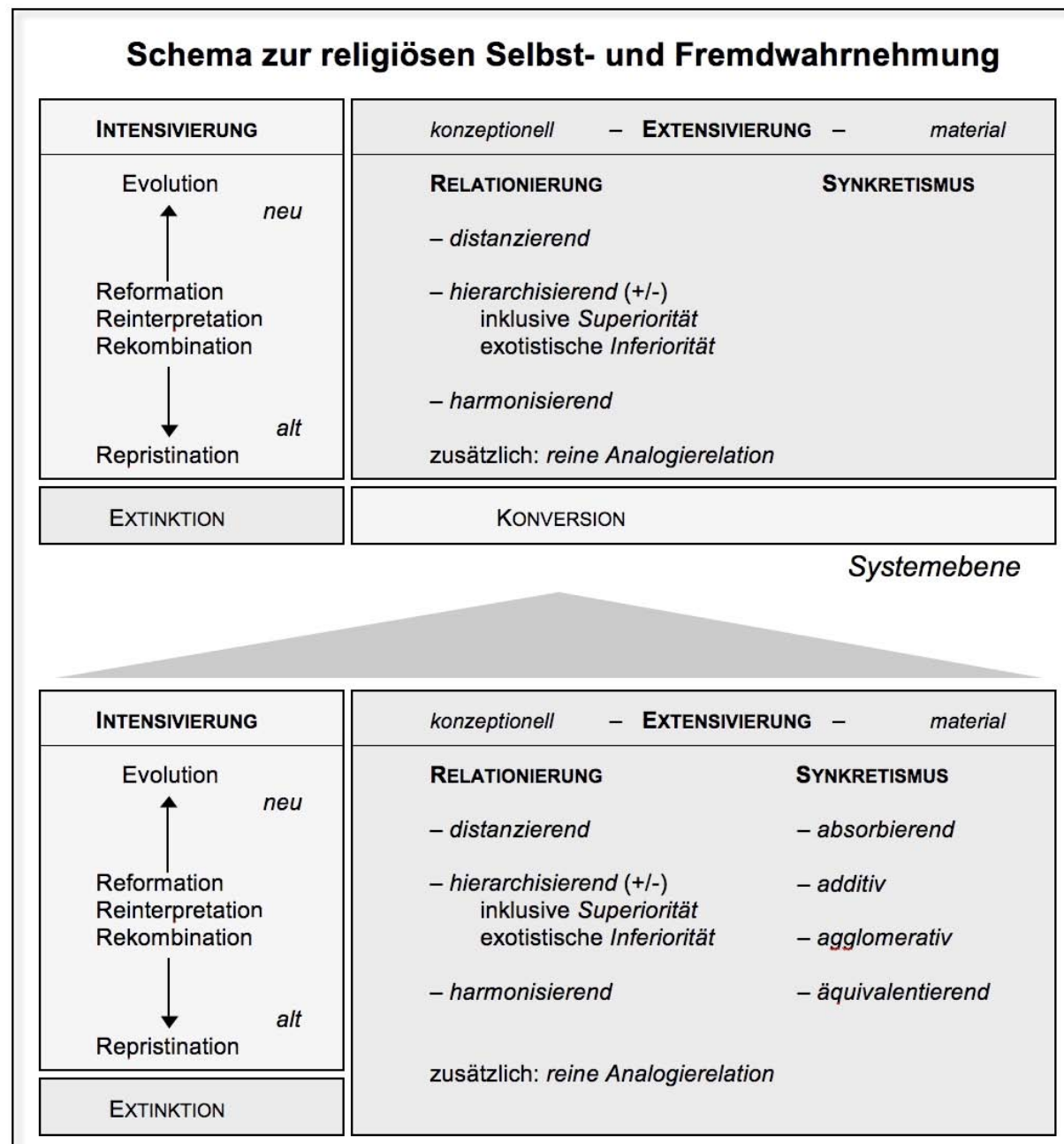

Elementebene

Dieses vereinfachte Tableau ${ }^{34}$ wurde nicht zur schlichten Etikettierung entwickelt, sondern es soll einer heuristischen F unk tion dienen: Durch die differenzierte Darstellung unterschiedlicher Ebenen und Optionen wird der Blick für die einzelnen Verhältnisbestimmungen und Transformationsprozesse in interreligiösen Verflechtungssituationen geschärft und die häufig multivarianten Überlagerungen können so wesentlich präziser erfasst werden.

34 Für die komplexere, ausführliche Fassung vgl. G rünschloß (1999: 80-85). 
Hinsichtlich der oben angesprochenen klassischen tripolaren Klassifikation (Inklusivismus, Exklusivismus und Pluralismus) ergibt sich daraus auch die Einsicht, dass die ,Verrechnung' dieser komplexen Verhältnisbestimmungsnetze selten einfach möglich ist, wenn gleichzeitig mehrere (gegenläufige) Relationierungen eingenommen werden. Außerdem ist die tripolare Klassifikation, zu deren systematischer Verteidigung v.a. Perry Schmidt-Leukel immer wieder angetreten ist, nach den o.a. Einsichten mindestens um die Kategorie „Exotismus“ zu erweitern. Die folgende Tabelle stellt im Anschluss an Schmidt-Leukels mengentheoretische Veranschaulichung ${ }^{35}$ die Minimalbedingungen für den jeweiligen Begriff im gestrichelt umrandeten Feld dar (die atheistische Position, die keinen Wahrheitswert für irgendeine Religion R1-Rx annimmt, scheidet für religiöse Traditionen i.d.R. aus): R1 bezieht sich auf R2 exklusivistisch, wenn nur für R1 ein voller und für R2 gar kein Wahrheitswert gesetzt ist - analog hierarchisch relativierend die inklusivistische Position mit der Feststellung von Teilwahrheiten, umgekehrt dagegen die ex otistische Reverenz gegenüber R2 und schließlich die pluralistische Option, wenn mindestens einer weiteren Rx derselbe Wahrheitswert zuerkannt wird.

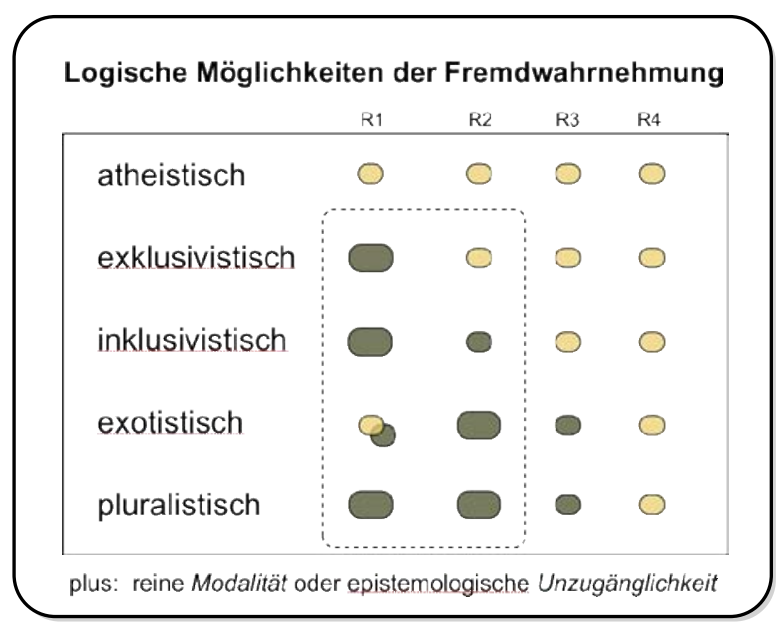

35 Vgl. z.B. Schmidt-Leukel (1998: 39-58 (hier: 41)), sowie ders. (1997: 65-97). 


\subsection{Fallbeispiele II - Vom (Neo-)Hinduismus zur diabolischen Islamkarikatur}

An der bekannten neohinduistischen Bewegung der „Internationalen Gesellschaft für KrishnaBewusstsein" (ISKCON) lässt sich das Zusammenspiel von intensivierenden und extensivierenden $\mathrm{Ope}$ rationen anlässlich bestimmter neuer Relationierungen nach innen wie außen gut illustrieren. Religionsintern wird die traditionelle Avatära-Lehre (die „Herabsteigungen" des Gottes Vișnu) insofern auf den Kopf gestellt, als nunmehr Krṣna selbst (normalerweise der jüngste Avatāra) als oberster Gott und Herrscher des Universums fungiert und nicht mehr Vișnu, der ihm hier als Erscheinung untergeordnet wird. Dies stellt eine systeminterne Rekombination im Lichte der - für diese Bewegung konstitutiven - Gottesliebe der Krssna-Bhakti dar. In der Relatio-

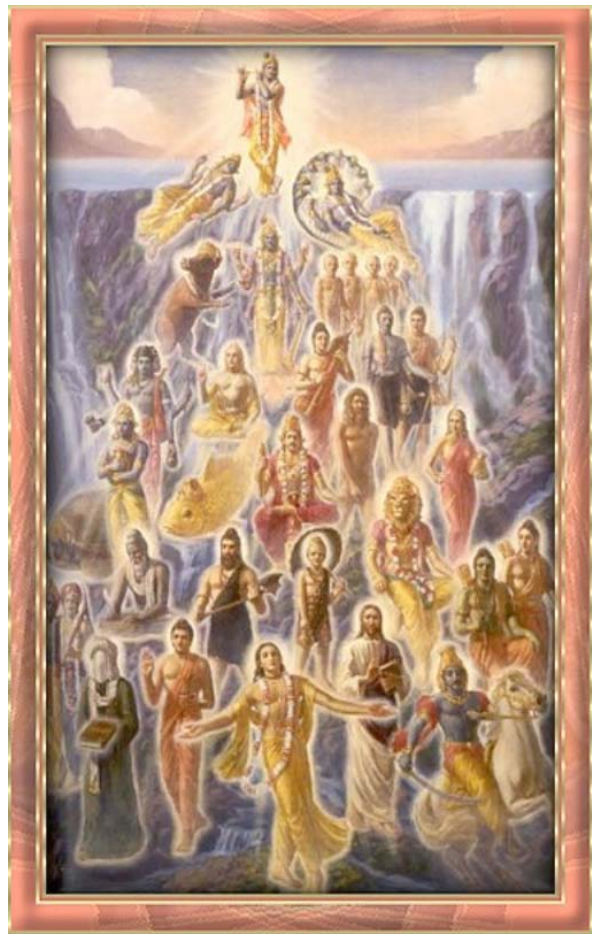
nierung nach außen werden nun aber auch mehrere neue Religionsstifter in das Avatāra-System integriert. Am unteren Rand des Bilds ${ }^{36}$ sind - von links nach rechts - zu erkennen: Muhammad (mit verschleiertem Gesicht), der Buddha und (rechts hinter dem wichtigen BhaktiReformer Caitanya) Jesus Christus mit dem Evangelium in der Hand. Daneben ist rechts im Vordergrund der zukünftige Avatära Kalkin auf dem weißen Pferd dargestellt. - Die bildhafte Repräsentation illustriert einen ganz typischen ink lusiven $\mathrm{G}$ estus, demzufolge Buddhisten, Muslime und Christen unter Umständen als BhaktiGeschwister angesehen werden können, aber gegenüber dem eigentlichen höchsten G ott Krṣna, den sie ja gar nicht kennen, in eine hierarchische Relationierung eingefügt werden.

Diese Vorstellung verdankt sich unmittelbar der Bhagavadgitā, die in Kap. 7,1923 und in Kap. 9,23-25 eine inklusive Religionstheologie entfaltet, die in vieler Hinsicht an Karl Rahners Lehre vom „anonymen Christentum“ erinnert: ${ }^{37}$ Krșna

36 Vgl. die Bildquelle: www.iskcon.de/ images/ parampara/ avataras.jpg.

37 Vgl. Grünschloß (1999: 174-178): Die Gītā-Stellen können dort nachgelesen werden (inkl. Kommentar), sowie auch bei $\mathrm{G}$ arbe (1988), oder Mylius (1997). 
verleiht gemäß dieses klassischen Hindutextes denen, „die ihre Zuflucht bei anderen Göttern nehmen“ (prapadyante 'nyadevatäh) einen unerschütterlichen „Glauben“ (śraddhä). Sie verehren die anderen Götter aus diesem Glauben heraus, merken aber nicht, dass K rṣna der eigentliche Herr und G enießer der O pfer und Verehrung ist; daher fallen sie in den Geburtenkreislauf zurück und erreichen keine endgültige Erlösung. Außerdem werden die ,Andersgläubigen' von ihrer „materiellen Natur" (prak riti) ,heruntergezogen'; sie können nur eine „endliche Frucht“ (antavat phala) genießen, ein vorläufiges, begrenztes G lück. Nur wer K rșna wissend und rechtmäßig verehrt, erreicht die Stätte seiner völligen Erlösung. - Es handelt sich hier um einen inklusivistischen Einschluss mit relativierender D epotenzierung der anderen Heilsmöglichkeit - bei gleichzeitiger Unterstellung niederer materieller Bindungen, die echte und nachhaltige spirituelle Ziele verunmöglichen (ich komme darauf zurück).

In ähnlich inklusiver Weise nahm der wohl erfolgreichste neohinduistische $\mathrm{G}$ uru, Sathya Sai Baba (*1926), Bezug auf Hindu-, Islam- und christliche Traditionen: Er versteht sich als ein Krșna und Rāma übersteigender Avatāra, als Wiederkehr des (sowohl von Hindus als auch Muslimen verehrten) Shirdi Sai Baba und als Inkarnation Śivas und seiner Śakti, soll aber nach seinem Tod als lichte Christusgestalt wiederkehren (nach eigener Auskunft). ${ }^{38}$ D as frühere Emblem der Sathya Sai-Religion drückte diesen all-inklusiven Anspruch unmittel-
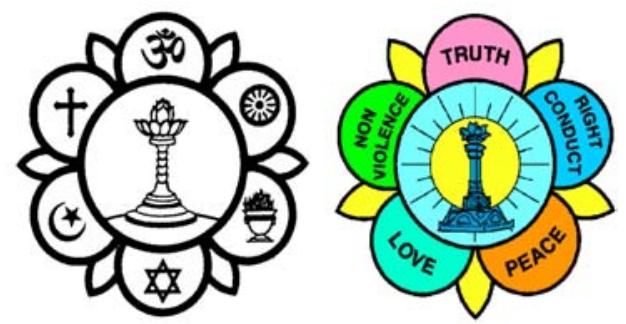
bar aus, indem es die Symbole anderer Religionen in sich vereinte und kreisförmig wie Blütenblätter um das Zentrum der Sathya Sai-Religion anordnete; wie man rechts sehen kann, wurde diese inklusive Symbolik aber vor einigen Jahren in ein interreligiös weniger anspruchsvolles Symbol mit abstrakteren Tugenden und G rundwerten transformiert.

Mit spitzem Humor hat Bhagwan Shree Rajneesh / O sho (Rajneesh Chandra Mohan, 1931-1990) gegen Ende des Jahres 1988 behauptet, Gautama Buddha habe vorübergehend von ihm Besitz genommen - und er habe sich dann mehrfach über Bhagwans luxuriösen Lebenswandel ereifert, so dass er ihn nach drei Tagen wieder ,hinauskomplimentieren' musste. Diese kleine Episode, die einiges Aufsehen (und Empörung bei Buddhisten) entfachte, zeigt den spielerisch-schelmischen Umgang mit ,heiligen' Elementen und Personen, die für diesen modernen Religionsgründer typisch waren, da er sich in der Pose des paradox handelnden Zen-Meisters oder lachenden Buddhas inszenierte, der Kritik an allen überkommen religiösen Institu-

38 Vgl. zur Einführung Poggendorf-Kakar (1999) - Die abgebildeten Symbole stammen aus Internetseiten der Satya Sai-Bewegung. 
tionen und Lehren übt. Auch sein Zugriff auf Jesus ist von diesem Charakter geprägt, ${ }^{39}$ denn es geht Rajneesh um einen „intuitiv“ erfassten Jesus jenseits des Christentums, jenseits der christlichen Tradition: „Wenn ihr Christus wollt, müsst ihr das Christentum hinter euch lassen. [...] Christus ist jenseits aller Kirchen." (Süss 1996: 153). Dieser Jesus habe durch seine „Präsenz“ gewirkt und für die, die ihm nachfolgen, ein "Fest" bereitet und sie in eine tiefe, spontane Innerlichkeit geführt. Jesus wird von Rajneesh daher - ganz anlog zu zen-buddhistischen JesusRezeptionen $^{40}$ - zu einem Mystiker stilisiert, der fromme Konventionen durchbricht.

D iese Aneignungen Jesu als eines erleuchteten Meisters, der spirituelle Erfahrungen vermittelt und die Menschen innerlich von Zwängen befreit, ist auch für viele buddhistische Thematisierungen von Jesustraditionen typisch. ${ }^{41}$ Diese inklusiven Aneignungen nehmen vor allem die spirituellen, buddhismuskompatiblen Elemente wahr (oder streichen sie besonders heraus), während andere (für die christliche Binnenperspektive) konstitutive Elemente marginalisiert und in ihrer Bedeutung heruntergespielt werden. D.h., wie in allen inklusiven Aneignungen handelt es sich um eine manifest selbstreferentielle Struktur, mit der bestimmte (bereits intern besetzte und bekannte) Elemente wiedererkannt und als positiv deklariert werden (was z.B. zur Spiritualisierung von Jesusworten führt), während andere, negativ attribuierte oder einfach nur ,uninteressante' Elemente unterschlagen und neutralisiert - oder direkt kritisiert - werden. Für den klassischen Buddhismus legen sich aufgrund der systemkonstituierenden Tendenz zum Exklusivismus ohnehin wenig inklusive Einlassungen nahe (vgl. Grünschloß 2000). So kommt auch Hapatsch in seiner jüngsten Studie über die Rezeption von Kirche und Christentum im deutschsprachigen Buddhismus zu dem Ergebnis: „Im Vordergrund der Christentumswahrnehmung steht auch heute noch die D istanzierung, nicht die inhaltliche Auseinandersetzung mit dem Christentum." (Hapatsch 2007: 324). Abgesehen von selbstreferentiellen Seitenbemerkungen scheint das Christentum für buddhistische Augen selten von großem Interesse zu sein; - wenn überhaupt, dann kann Jesus „positiv“ gesehen werden, während die Kirche als organisatorische G röße eigentlich stets „negativ“ wahrgenommen wird.42

Die Identifikation solcher negativer Elemente rückt bei distanzierenden Relationierungen ganz in den Fokus der Rhetorik, da hiermit der völlige U nwert der andersreligiösen Tradition oder Position besonders betont und dramatisiert werden kann.

\footnotetext{
39 Vgl. hierzu den Überblick bei Süss (1996: 151-166) („Rajneesh und sein Jesusbild“).

40 Vgl. z.B. Leong (2000).

41 Vgl. Schmidt-Leukel/ Götz/ Köberlin (2001), Grünschloß (2005) sowie ders. (2008) und die umfangreiche Arbeit über Buddhismus und Christentum v. Brück/ Lai (1997).

42 Hapatsch zeigt dies u.a. auch an einer Inhaltsanalyse buddhistischer Internetforen, in denen das Christentum stets als spirituell defizitär aufgefasst wird und die Kirche als unpersönlich-abstrakte Institution ohne Leben erscheint. Auch die Vorstellung eines persönlichen Gottes wird als überflüssig abgelehnt (und manchmal mit Amida-buddhistischen ,Verirrungen' analogisiert), wobei der christliche „Glaube“ als ein stures Für-wahr-Halten dargestellt wird (vgl. Hapatsch 2007: 186-230; „Buddhismus im Cyber-Space - Buddhistische D iskussionsforen").
} 
Im obigen Beispiel aus der Bhagavadgitā klang neben den hierararchisierendinklusiven Relationierungen ebenfalls eine distanzierende Zuschreibung von niederen (materiellen) Eigenschaften an, mit der die unzureichende religiöse Realisierung fremdreligiöser Vollzüge zusätzlich begründet wird - und zwar im Modus einer genetischen Distanzierung. D er andersreligiöse Vollzug wird demnach in seiner $\mathrm{Ge}$ nese auf mindestens unzureichende bis völlig in die Irre führende Motivationen und Treibe zurückgeführt: Die "Andersgläubigen" (anyadevatäbhakäh) werden in Bhg 7,2 als „bar jeglicher Erkenntnis“ (hrtajñanāh) bezeichnet, sowie als „von Trieben“ (kämaih) gesteuert und der „Materie“ (prak rti) verhaftet. D ies wird in den späteren Kapiteln 16 und 17 der Gìtā noch ausführlicher entfaltet, indem eine regelrechte Typenlehre zugrunde gelegt wird, die eine Klassifikation der Menschen und der ihnen jeweils möglichen religiösen Realisations- bzw. Befreiungsgrade entlang der materiellen Verhaftung in den drei gu nas der prak rti (A ggregatzustände der Materie) erlaubt: „D ie sattva-artigen dienen den Göttern, die rajas-artigen bösen G eistern und $\mathrm{Dämonen}$, und die anderen, die tamas-artigen, dienen den Verstorbenen und Gespenstern“ (Bhg 17,4). - Materie- und Weltverhaftung, spirituelle Unfähigkeit (bis hin zur Unterstellung von G eisteskrankheit) oder sogar die Abhängigkeit von einem unzureichenden bzw. falschen (dämonischen) numinosen Personal - all das sind Möglichkeiten, die Differenz zum religiös Anderen und Fremden zu betonen und auf eine falsche oder zumindest unzureichende $\mathrm{G}$ enese zurückzuführen.

D iese Vorgehensweise findet sich z.B. während der Ausbreitung des Christentums vielfach in missionstheologischen Bezugnahmen auf die vorgefunden Religionskulturen. Zwar kann mitunter eine ahnende Wahrnehmung des „unbekannten Gottes" (gemäß Apg 17,23) konstatiert werden,43 häufiger überwiegen jedoch die dämonisierenden Interpretationen, die das fremdreligiöse Personal mit den diabolischen Akteuren aus der bekannten numinosen Halbwelt des Christentums identifizieren: D ie fremden Götter sind dann nichts anderes als Teufel oder dämonische Vasallen. Dies spiegelt sich z.B. paradigmatisch in den reich illustrierten Reiseberichten von De Bry, die für die europäisch Wahrnehmung der Einwohner der „neuen Welt" nachhaltige ikonographische Konventionen lieferten: D ie Religion der Indianer wird dort häufig als abgöttischer Teufelsdienst dargestellt, und ihre Gottheiten werden entlang europäischer D ämonen-, Monster- und Teufelskonventionen visualisiert (vgl. nachstehende Abbildung ${ }^{44}$ ).

43 Das Konzilsdekret N ostra A etate (1965) des II. Vatikanischen Konzils bezieht sich in seiner Stellungnahme zu den nichtchristlichen Religionen - mit ihren jeweiligen Teilwahrheiten (Strahlen der Wahrheit) - auf die biblischen Leitmotive 1 Tim 2,4 und Apg 17 (NA 2; vgl. analog in der Kirchenkonstitution L umen G entium LG 16). - Die spätere päpstliche Verlautbarung zur Mission „Evangelii Nuntiandi“ (1975), die sich für die stärkere Berücksichtigung des dimensionalen Missionsverständnisses aussprach (Entwicklung, G erechtigkeit, Befreiung), greift im Bezug auf die Religionsthematik wieder wesentlich kürzer: Die „nichtchristlichen Religionen“ könnten zwar als eine „Vorbereitung auf das Evangelium “ angesehen werden, sie vermögen jedoch keine „echte Verbindung mit G ott" herzustellen, „auch wenn sie sozusagen ihre Arme zum Himmel ausstrecken (EN 53). - Vgl. dazu die Quellenanalysen und Kommentare bei G rünschloß (1994: 129-134).

44 Die Abbildung stammt aus der Zusammenstellung von Sievernich (1990: 149); vgl. für eine analog diabolische Abbildung 179 („D er Indianer Religion oder G ottesdienst“). - Auch die in der Abbildung 


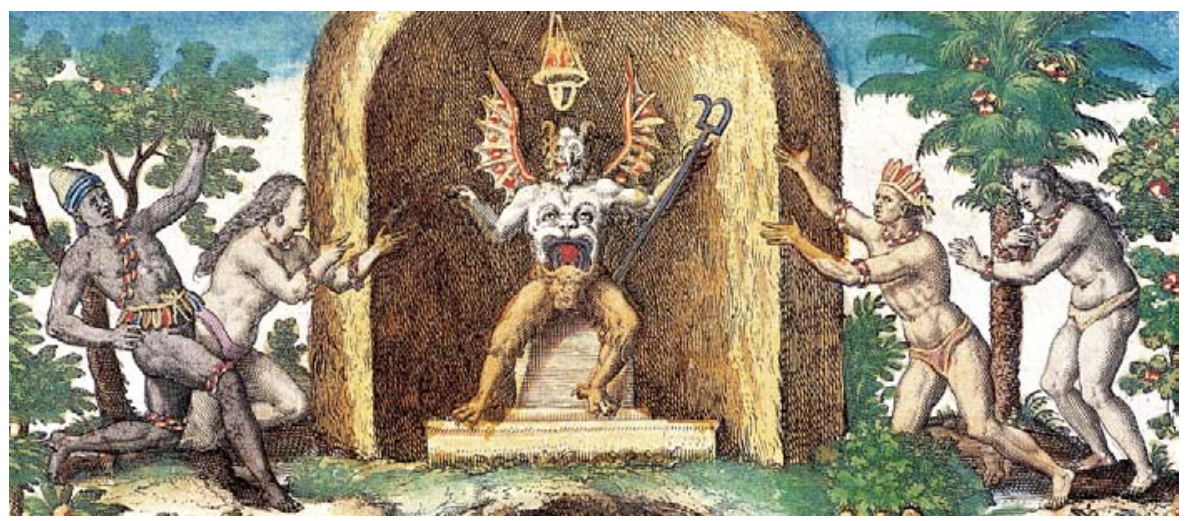

Ausschnitt aus dem Titelbild von Band IV der Reiseberichte „Americae“

von Th. de Bry (Frankfurt 1594)

Diese polemische Interpretatio diabolica kulminiert z.B. in der europäischen Neuerfindung der aztekischen Zentralgottheit Huitzilopochtli, die dann als „Vitzliputzli“ sogar Eingang in das Arsenal europäischer Teufelspersonen findet und schließlich in verharmloster Form als „Fitzebutze“-Teufelchen in Kinderbuch und Puppentheater reüssiert.45 (Ich verweise auf die ausführlichere Behandlung des Themas solcher diabolischer Rekonstruktionen in meinem früheren WGTh-Kongressbeitrag über die europäische Rezeption der aztekischen Religion (Grünschloß 2006).) Diese Stigmatisierung des religiös Anderen durch diabolische Interpretationen seiner Numina ist keineswegs ein Relikt der Vergangenheit. Zwar gab es seit dem 8. Jahrhundert im christlichen Abendland zwei „D eutemuster zur theologischen Bewältigung der Herausforderung, die der Islam für das christliche Selbstverständnis darstellte: Es war dies zum einen das Verständnis des Islam als christliche Irrlehre, als Ketzerei also - und zum anderen die noch schärfere Verurteilung als unchristlicher oder antichristlicher Irrglaube - als Rückfall ins Heidentum." (Bernhardt 2004). D och anknüpfend an diese paradigmatische - und nachhaltige - ,Entlarvung' des Islam als $\mathrm{H}$ äresie und Teufelsglaube bzw. als Verführungsmacht der nahenden Endzeit bei Johannes von Damaskus (ca. 650-754) meinen auch heute noch manche evangelikale Stellungnahmen zum Islam in Muhammad jenen endzeitlichen „falschen Propheten“ aus der Johannesapokalypse (Apk 19,29) mit seinen falschen "Zeichen“ ( sichts dieser Erscheinung des „Antichristen“ sei der Islam insgesamt als eine „end-

sichtbare Körperfratze gehört zum monströsen Inventar der diabolisch-dämonischen Ikonographie in Europa, die sich auch in mehreren europäischen Huitzilopochtli-D arstellungen wiederfindet; vgl. Boone (1989: 67-83) („D iabolic analogy“).

45 Vgl. das relativ berühmte Kinderbuch von Paula D ehmel und Richard D ehmel: Fitzebutze. A llerhand Schnick schnadk fur Kinder (1900), das zuletzt in einer Ausgabe von E. K reidolf (Hg.) neu aufgelegt wurde (Frankfurt/ M. 1984); vgl. die erste Umsetzung zum Puppenspiel bei R. D ehmel, Fizebutze. Traumspiel in 5 A ufzügen, Berlin 1907, sowie insgesamt zu diesem Rezeptionsstrang Stark u.a. (2000). 
zeitliche Verführungsmacht" zu verstehen, der man sich nicht im Modus eines interreligiösen Dialogs, sondern „evangelistisch zielklar" entgegenzustellen habe.46 Ähnliche Stellungnahmen finden sich mitunter bei Leserbriefen im Kontext von Moscheebauvorhaben und natürlich auch im Internet47. Die 1999 erschienene theologische Erklärung des Theologischen Konvents bek ennender G emeinschaften „Kein anderer Name!" hält zwar einerseits fest, dass das religiöse Streben der andersreligiösen Menschen nicht „nur als Aufruhr gegen Gott zu beurteilen sei“ (§ 5.3), kommt dann aber doch wieder ganz programmatisch auf die dämonologische Interpretation der nichtchristlichen Religionen zurück (§ 7):48

Die dämonische Komponente der Religionen (Quelle: Kein anderer Name! 1999)

D ie H eilige Schrift verurteilt die heidnische Religion deswegen, weil diese durch die Rebellion des $M$ enschen gegen $G$ ott geprägt ist und darüber hinaus satanisch beeinflusst ist. Beides bestimmt in $\mathrm{G}$ egenbewegung zu $\mathrm{G}$ ottes allgemeiner 0 ffenbarung - die empirische $\mathrm{G}$ estalt der R eligionen mit.

W ir glauben und erk ennen: Die von Gott abgefallenen Menschen werden in ihrer religiösen Ausrichtung und Praxis bewegt von eigensüchtigem Begehren nach Gottgleichheit, Macht, Wissen und Lebensfülle (1 Mose 3,4-6; 11,1ff; Habakuk 1,11b). Unter dem Einfluss von $\mathrm{G}$ ottes Widersacher, dem Teufel, verehren sie anstelle des wahren Gottes A bgötter, hinter denen sich reale dämonische Mächte verbergen (1 Korinther 10,20). Dadurch führt die dem Menschen verbliebene echte Erkenntnis Gottes nicht zur Ihm geschuldeten $\mathrm{G}$ anzheitshingabe in Lobpreis und G ehorsam. Vielmehr tritt in unterschiedlichem Ausmaß - eine geistliche Verblendung oder - im Extremfall sogar spiritistische Versklavung ein (5 Mose 18,9-12; Römer 1,21-23; Jesaja 44,9; 2 Korinther 4,3f.; G alater 4,8).

46 In der Broschüre Christliches Bekenntnis und biblischer Auftrag angesichts des Islam. Ein Wort der Konferenz Bekennender Gemeinschaften in evangelischen Kirchen D eutschlands und der AG evangelikaler Missionen, Bielefeld/ Stuttgart 1984, finden sich folgende Aussagen: „Wir erkennen im Islam ein $G$ ericht $G$ ottes über eine Christenheit, die sich vielfach vom biblischen Evangelium entfernt hat. Wir erkennen im Islam aber auch eine endzeitliche antichristliche Verführungsmacht (1 Joh 2,18.22), die sowohl dem alten Bundesvolk der Juden als auch der Kirche Jesu Christi widerstreitet. Ihre G efährlichkeit liegt in ihrer täuschenden Nachahmung der biblischen Offenbarung. Wir rufen deshalb alle Christen auf, den Islam wachsam zu studieren, seinen Anhängern evangelistisch zielklar zu begegnen und seinen Irrlehren in geistlicher Abwehrbereitschaft (Eph 6,10-17) entgegenzutreten" (Abschnitt V des D okuments; Bezug über Institut Diakrisis, G omaringen).

47 Angesichts der Leugnung von Jesu Gottessohnschaft im Koran sei Muhammad eindeutig als der "Antichrist, der den Vater und den Sohn leugnet" (1 Joh 2,22) zu deuten (http:/ / deislam.wordpress.com/ 2008/ 01/ 19/ was-ist-mohammed-im-vergleich-zu-jesus-christus).

Vgl. ganz analog die Einlassungen zu Muhammad in einem Diskussionsforum: www.geistigenahrung.org/ ftopic29271-20.html.

48 Theologischer Konvent Bekennender G emeinschaften (1999). 
Wie bereits dargestellt, handelt es sich bei solchen Relationierungen um eine genetische D istanzierung, da die andersreligiösen Vollzüge auf einen anderen, falschen - und zwar diabolischen - Ursprung zurückgeführt werden (vgl. Grünschloß 1999: 246f.). D ie Spanier sahen in den einheimischen Göttern der Azteken auch nichts anderes als Menschen mordende Dämonen und „Teufel“ (diablome).49 - In der christlichen Wahrnehmung Muhammads trat neben die Identifikation mit antichristlichen Ursprüngen und Motiven auch oft die genetische Distanzierung durch geistig-moralische A bqualifizierung, wonach Muhammad entweder als "geisteskrank" hingestellt wurde oder wegen der - in christlichen Augen unverzeihlichen - Polygamie als moralisch verdorben und geradezu sexbesessen. ${ }^{50}$ Fernwirkungen dieser moralischen Abqualifizierungsdiskurse gegenüber Muhammad fanden sich z.B. nach den Anschlägen vom 11. September 2001 vor allem in den USA wieder, wie die nachfolgende erste Strophe aus einem Lied zeigt, das über die D omain „islamcomicbook.com" als Audio-Datei zu hören ist und Muhammad der krankhaften Perversion angesichts der Verführung einer Minderjährigen bezichtigt (natürlich in völliger Unkenntnis oder sogar in bewusster Unterschlagung der damaligen gesellschaftlichen Konventionen): 51

They tried to tell me my religion was wrong. / They tried to tell me to follow Islam.

They said their "Prophet" was a righteous dude, / But I found out none of their words were true. I read the Q ur'an and I read the Hadith, / And the sickness of Mohammed was apparent to me. He justified perversion in the name of Allah, / When he married a girl too young for a bra.

She was playing with dolls when the "Prophet" came. / Her childhood was stolen in Allah's name. Aisha was nine when he took her to bed. / D on't tell me that fool's not sick in the head.

[Refrain:] I ain't gonna follow no child molester, sex offender, Prophet pretender.

I ain't gonna follow no child molester! Islam's not for me! Islam's not for me! [...]

\subsection{Systematische Zwischenüberlegung II - Die inhaltliche Deutung religiöser Alterität zwischen D eduktion und Induktion}

Wie diese Beispiele gezeigt haben, können religiöse D eutungen des religiös Anderen und Fremden entweder die (partielle) Offenheit für eine Transzendenzwahrnehmung zugestehen, oder die andere Religion wird in ihrer Entstehung, Motivation und Funktion auf eine rein immanente Sphäre reduziert (,horizontalisiert'). Die bis weit in die heutige Theologie hineinreichende Tendenz, die eigene (christli-

49 In den Religionsgesprächen der zwölf Franziskanermönche mit aztekischen Adligen wurde daher schnell das Wort diablos (im Nahuatl-Plural diablome) zur Bezeichnung der einheimischen Numina eingeführt, als die Anknüpfung an einzelnen Hochgott-Prädikationen scheiterte. Vgl. Wißmann (1981).

50 Auch hierzu bietet bereits Johannes von Damaskus eine Vorlage; vgl. Khoury (1969: 14f.) - Vgl. die kompakte Zusammenstellung der zentralen Allostereotypen zum Islam bzw. Muhammad bei Watt (1992: 100-105) („,D as verzerrte Bild des Islam“): Die Ablehnung zölibatärer Lebensweisen (Mönchtum), die Vielehe und die prallen Paradiesschilderungen mit den „Huris“ lieferten im Christentum des Mittelalters viel Stoff für die Zuschreibung genussüchtiger Perversionen.

51 Vgl. im Internet: http:/ / islamcomicbook.com; die Seite schürt Ängste vor einer islamischen Unterwanderung („Ameristan“) und wartet mit despektierlichen Islam-Comics auf. 
che) Religionstradition als durchlässig für die wahre Transzendenz anzusehen, die anderen Religionen dagegen (u.a. mit Mitteln der deskriptiven Religionswissenschaft) als lediglich historisch und gesellschaftlich bedingte intramundane $\mathrm{G}$ rößen darzustellen, hat Wilfred C. Smith prägnant auf den Punkt gebracht: „This is to look for essences; to Platonize one's own faith and to Aristotelianize other peoples'. "(Smith 1978: 57). D em wäre noch die 0.a. negativ akzentuierte Religionsdeutung hinzuzufügen, die weder die D urchlässigkeit zu einer positiven Transzendenz (in unterschiedlichen $\mathrm{G}$ raden) noch die bloß intramundane Bedingtheit oder Funktion der anderen Religion herausstreicht, sondern den anderen Religionsvollzug in weitaus radikalerer Polemik dämonisiert und ihn als Resultat einer satanischen oder dämonischen Macht (d.h. als Produkt einer negativen Transzendenz) interpretiert.

Somit lassen sich die einzelnen inhaltlichen Erklärungsversuche im Rahmen unterschiedlicher (exklusiver, inklusiver oder pluralistischer) Religionsdeutungen in einem Schema verorten, das dem weltweit stark verbreiteten D rei-Welten-Modell entspricht (siehe Abbildung): Eine Religion (oder ihre Gottheit bzw. Praxis) kann a) vertikal im Sinne eines realen Transzendenzbezugs interpretiert werden (Essentialisierung) oder b) horizontal auf historische, soziologische oder psychologische Funktionen reduziert werden (immanente Reduktion, Horizontalisierung); in diesem Fall würden die Religionen rein als $\mathrm{f}(\mathrm{x})$ dargestellt (wobei $\mathrm{x}=\mathrm{G}$ [eschichte], S[oziologie], $\Psi$ [Psychologie]). Schließlich kann Religion auch c) vertikal in negativer H insicht auf ein Produkt satanischer Mächte reduziert werden (Dämonisierung).

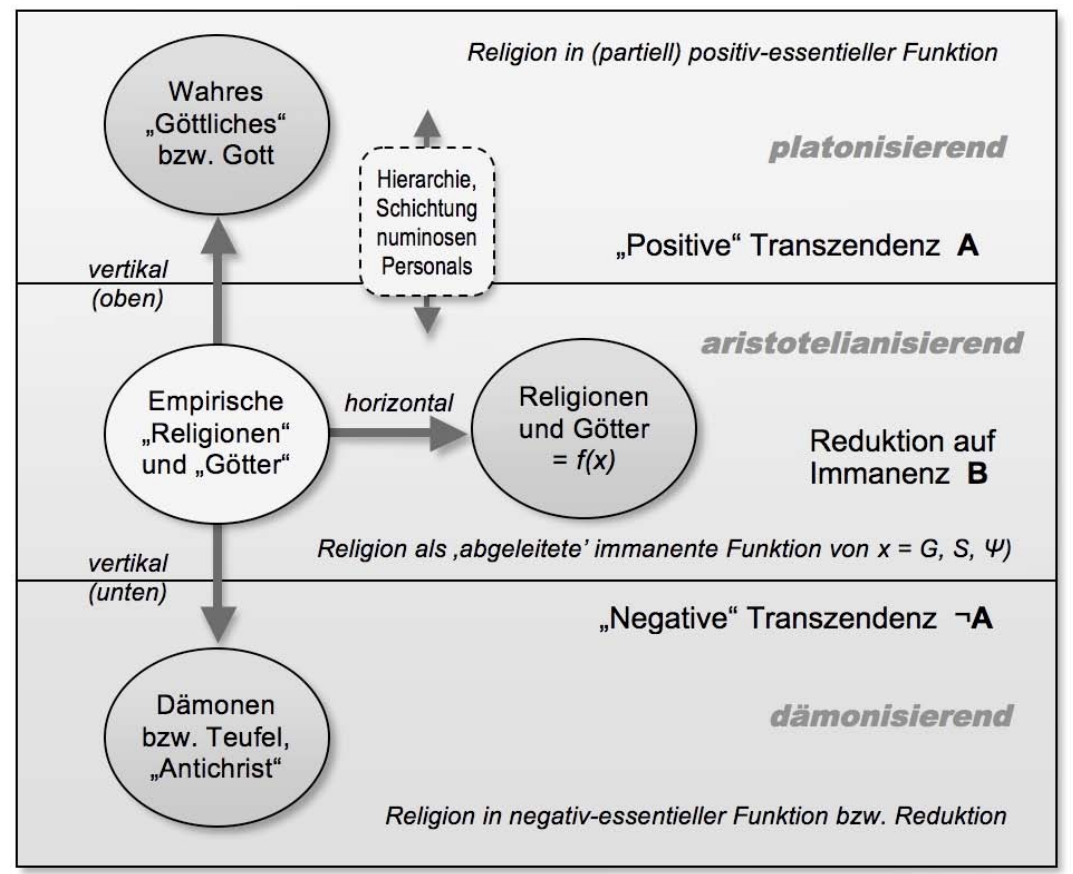


Das Schema liefert gleichsam ein „Koordinatensystem“ typischer Religionsdeutungen, wobei sich Argumentationen aus allen drei Ebenen miteinander kombinieren lassen. Wie die gestrichelt eingezeichnete Box verdeutlicht, kann in Bezug auf das jeweilige numinose Personal einer anderen Religion die ,Durchlässigkeit' für reale Transzendenzerfahrungen auch in unterschiedlichen $\mathrm{G}$ raden hierarchisch gestaffelt werden - am aztekischen Beispiel erläutert: Während Huitzilopochtli in der interreligiösen Fremdwahrnehmung zum völligen Erzteufel umfunktioniert (und inkorporiert) wurde, konnten sich mit Q uetzalcoatl christianisierende Deutungen im Stile einer präparatio evangelii bis hin zu Vorstellungen eines manifesten, wenngleich verborgenen Wirkens Christi verbinden (heute noch v.a. bei den Mormonen). 52

Die Interpretation der fremdreligiösen Lebensvollzüge geschieht also nach Maßgabe religiös motivierter Deduktionen aus dem eigenen religiösen D eutungshorizont. D iese platonisierenden und dämonisierenden Zuschreibungen verdanken sich der Wahmehmung von A nalogierelationen (vgl. dazu oben in Abs. 2.2) zwischen dem Eigenen und dem Fremden, die entweder eine positive Nähe oder Affinität entstehen lassen können oder eher an bestimmte, in der Tradition etablierte Ketzerstereotypen erinnern (klassische Irrlehren): so etwa die Rückmeldung katholischer Missionare nach der Begegnung mit dem Amida-Buddhismus in Japan, dass hier der Teufel offenbar auch schon die lutherische Häresie verbreitet habe. - D ie Aussagen über die religiös Anderen können dann zusätzlich mit historischen, soziologischen oder psychologischen Religions-E rk lärungen verbunden werden. Ein Beispiel hierfür wäre die Art und Weise, wie der Religionsstifter der neoislamischen Ahmadiyya-Bewegung (G hulam Ahmad, 1835-1908), in manchen seiner Schriften Einzelergebnisse der damaligen historisch-kritischen Forschung zum Christentum dergestalt rezipiert, dass sie einseitig und mitunter geradezu ,immanentistisch' gegen Wahrheitsansprüche des Christentum gewendet werden können; andere Lehren (wie die Auferstehung Christi) werden von ihm einerseits in traditionell islamischer Weise theologisch abgelehnt, andererseits liefert seine Sonderlehre vom Indienaufenthalt Jesu nach der ,scheinbaren' K reuzigung noch einmal eine zusätzliche immanente Begründung ihrer Unwahrheit (inkl. der Tradition eines ,echten' Jesusgrabs in Srinagar). ${ }^{3}$

Das Problem, das sich beim ,D urcharbeiten' des fremdreligiösen Materials für eine religiöse bzw. ,religionstheologische' D eutung stellt, ist die Frage nach der Akribie und Gewissenhaftigkeit, mit der man sich der interreligiösen Auseinandersetzung stellt: Werden die Aussagen über die religiöse Alterität relativ schnell und unproblematisiert aus dem eigenen Traditionskanon deduk tiv abgewidk elt oder kommen sie durch eine intensivere Auseinandersetzung im ,Feld' zustande, bei der die fremden

\footnotetext{
52 Ich verweise für diese D oppelung der Rezeption unter umgekehrten Vorzeichen auf meine D arstellung in „Brutale Menschenschinder und ,Edle Wilde' ..." (Grunschloß 2006).

53 Vgl. hierfür Ahmad (1988), analog Ahmad (1992) - vgl. kritisch aus religionswissenschaftlicher Perspektive, sowie insgesamt zur historischen D ekonstruktion der „Jesus in Indien“-Legenden Klatt (1988).
} 
Lebensäußerungen dann auch so weit wie nur möglich unvoreingenommen und innerhalb ihres jeweils anderen D iskurs- und Plausibilitätszusammenhangs wahrge nommen werden, bevor man wieder in die vergleichende und religiös deutende (eigene) Perspektive zurücktritt. In gewisser Weise stehen hier religionswissenschaftliche und religionstheologische D eutungen vor demselben Problem: G ewinne ich meine Erkenntnisse durch rein deduktive (K urz-)Schlüsse im Horizont der eigenen Selbstreferenz (interpretationsimprägnierte, theoriegeleitete Erkenntnis), oder kann ich sie vor empirisch verlässlichen, induktiv gesicherten Erfahrungen und Beobachtungen im Feld verantworten? In Anknüpfung an Michael Pyes Überlegungen zur Struktur religionswissenschaftlicher Forschung (Pye 1999/ 2000) lässt sich Folgendes feststellen: Je stärker eine Untersuchung von der direkten empirischen „Wahrnehmung" - d.h. der konkreten E rschließung und Charak terisierung - des Feldes weiter in der Bereich systematischer „Erklärungen“ fortschreitet, bei denen es um Struk turanalysen und die Korrelation mit anderen, vergleichend heranzuziehenden Befunden geht, desto mehr steigt die Spannung mit dem Selbstverständnis der jeweiligen Gläubigen („tension with believers“, TWB). Pye spricht daher von einem allmählich steigenden TWB-factor, je mehr die Ebene des "Vergleichs" erreicht wird, da die G läubigen die hier stattfindenden Erklärungen häufig nicht (mehr) mit ihrer Binnenperspektive in Einklang bringen können (etische und emische Perspektiven können nie völlig zur D eckung gebracht werden). Eine im Vorfeld der Untersuchung herangetragene Theorie (oder Arbeitshypothese) muss aber durch "dichte" empirische Erkenntnisse im Feld kontinuierlich herausgefordert und somit bewährt, modifiziert oder verworfen werden, damit nicht über die betreffenden Menschen ,hinwegtheoretisiert' wird (hermeneutischer Zirkel bzw. mehrfache spiralförmige Rückkoppelung).

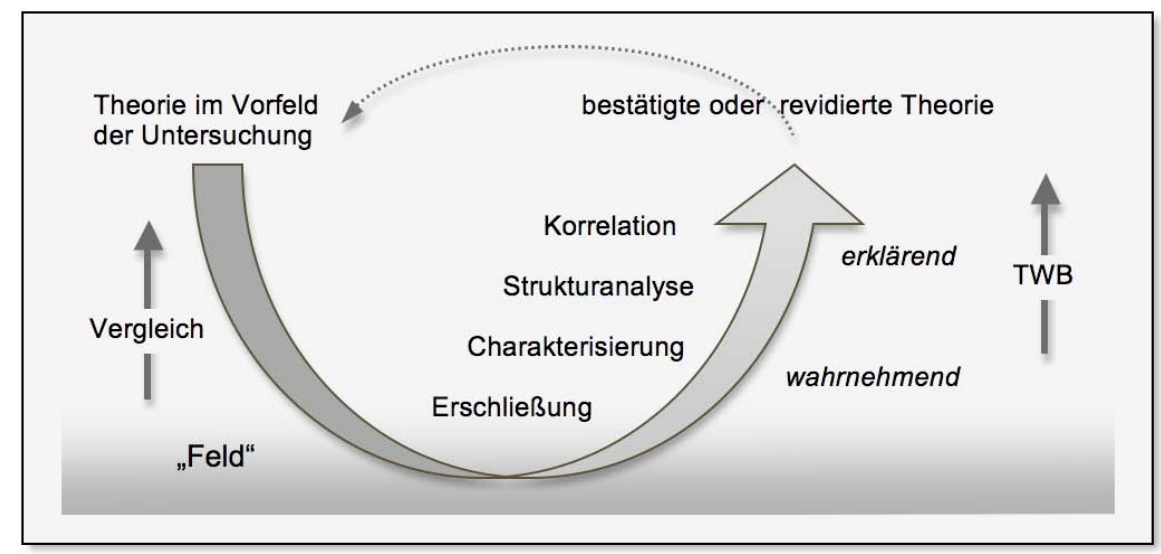

Schema zum Forschungsprozess innerhalb religionswissenschaftlicher Erhebungen 
Die Aufgabe religionstheologischer Stellungnahmen stellt sich letztlich ganz ähnlich. Im Unterschied zur empirisch religionswissenschaftlichen Analyse ist hier jedoch die Verbindlichkeit der religiösen Ausgangsperspektive durch die eigene Tradition „privilegierter Information“ ganz anders ,festgelegt” (auch wenn sich z.B. bei stark theoriegeleiteten sozial- oder religionswissenschaftlichen Analysen analoge Probleme hinsichtlich der D urchschlagkraft einer Leitperspektive ergeben können). Für religionstheologische Positionsbestimmungen stellt sich - zumindest unter modernen, rational verantworteten Diskursbedingungen - das Problem, inwiefern sich die Stellungnahme zum religiös Anderen einer eingehenden (d.h. umsichtigen, sensiblen und empathischen) Wahrnehmung im andersreligiösen Diskurs- und Handlungsfeld stellt oder ob sie ,schneller' - ,kurz-schlüssiger' - Interpretationen aus dem Reservoir der systemintern vorhandenen D eutungsschemata extrapoliert, mit denen die zur Interpretation anstehenden andersreligiösen Sachverhalte deutend und wertend ,überzogen' werden - womöglich vorschnell, in Abhängigkeit von normativ-selbstreferentiellen Differenzpostulaten.

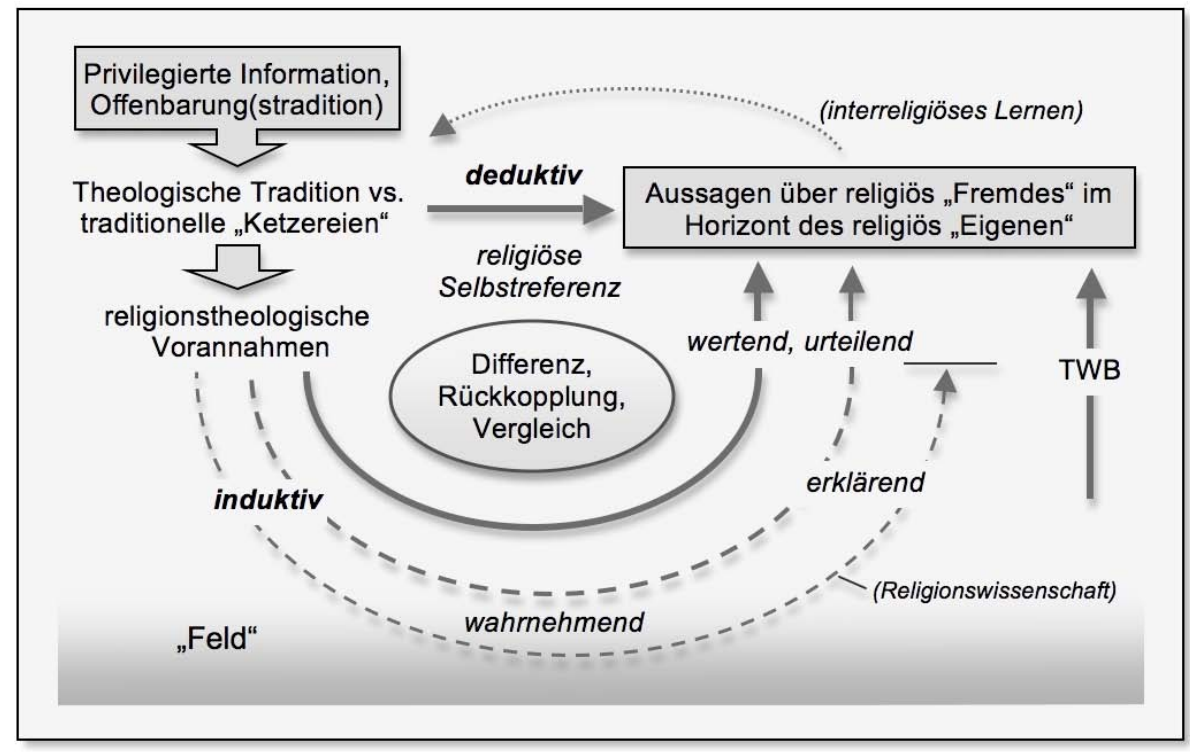

Wahrnehmungs- und Interpretationsebenen bei religionstheologischen Stellungnahmen

Die Plausibilität religionstheologischer Aussagen - welcher religiösen Tradition auch immer - wird sich stets daran messen lassen müssen, inwieweit sie ,dicht bei den Menschen' der anderen Tradition geblieben ist und deren emische Perspektive berücksichtigen und würdigen kann (zumindest wäre dies ein wichtiges Kriterium für christliche Religionstheologien). Je mehr aber eine theologische Wahrnehmung 
über die dialogische Felderschließung hinaus in die systematische und schließlich theologisch bewertende $\mathrm{E}$ bene fortgeführt wird, desto mehr wird sich auch hier der 0.a. TWB-factor einstellen, da diese selbstreferentiell rekonstruierten Aussagen nicht mehr ohne weiteres perspektivenübergreifend kommunizierbar sind (vgl. die inklusivistischen Beispiele in 2.3, die das Andere zum Teil aneignend ent-eignen). Eine religiöse Perspektive kann bei der interreligiösen Urteilsbildung nicht auf eine angemessene Berücksichtigung des eigenen Traditionszusammenhangs verzichten (diese religiöse Selbstvergewisserung und theologische Bewertung trennt sie vom religionswissenschaftlichen Vollzug), sie darf sich aber auch nicht der tieferen Auseinandersetzung mit dem religiös Anderen verweigem, weil sonst nur binnenperspektivisch selbst-verständliche Bilder religiöser Alterität entworfen würden - interpretationsimprägnierte homelands, in denen womöglich nur leblose Erfindungen angesiedelt sind, aber keine leibhaftige Wirklichkeit mehr erscheinen kann. Testfrage: Wird der Bogen vom Eigenen zum Anderen direkt von der religiösen Selbstreferenz aus geschlagen, oder geht er in tieferen Schleifen auf das Feld religiöser Alterität ein?

Der Weltkirchenrat hat daher in den „Leitlinien zum Dialog“ (1979) die Dialog-Theologie konsequent im biblischen Verbot der Lüge verankert: Die interreligiöse Wahrnehmung muss christlicherseits so gestaltet sein, dass $k$ ein falsches Z eugnis entsteht wider den $\mathrm{N}$ ächsten. ${ }^{54}$ Und analog könnte im buddhistischen Fall das dortige Grundgebot des „Nicht-Schädigens“ in der Sphäre der interreligiösen Auseinandersetzung so fruchtbar gemacht werden, dass den Menschen anderen Glaubens auch hermeneutisch kein Schaden mehr zugefügt wird (vgl. G rünschloß 2008: 263f.) was angesichts der vielen exklusiven G eltungsbehauptungen der buddhistischen Tradition und selbst angesichts der inklusiven Superioritätsansprüche des Mahāyāna eine ähnliche Herausforderung bedeutet wie für viele christliche Traditionen. 55 - Religiöse Aussagen über religiöse Alterität können sachhaltige und auch perspektivenübergreifend vermittelbare Stellungnahmen enthalten, wenn sie nicht in purer Selbstreferenz vom Eigenen her entworfen sind, sondern auf einer tiefer gehenden dialogischen Ausdauer in der Wahrnehmung von Angesicht zu Angesicht beruhen - denn nur so kann es religiösen Perspektiven gelingen, ihre geradezu chronische „Allergie" gegenüber dem religiös Anderen und Fremden zu überwinden, interreligiöse Lernerfahrungen aufzugreifen und in den Prozess der Beurteilung zu integrieren.

$54 \mathrm{Vgl}$. in den ÖRK- „Leitlinien zum Dialog mit Menschen verschiedener Religionen und Ideologien“ von 1979 in §17: „D er Dialog kann als ein geeigneter Weg der gehorsamen Erfüllung des Gebotes gesehen werden: ,D u sollst kein falsch Zeugnis reden wider deinen Nächsten.' D er D ialog hilft uns, das Bild unseres Nächsten, der einer anderen Religion oder Ideologie angehört, nicht zu entstellen." Eine Online-Version der G uidelines findet sich unter www.oikoumene.org/ fileadmin/ files/ wccmain/ documents/ p6/ 77glines-g.pdf.

55 Vgl. insgesamt die Beiträge zu P. Schmidt-Leukel (2001). 


\subsection{Fallbeispiel III - Die Religionstheologie der Zeugen Jehovas}

Unter dem Titel „Die Suche der Menschheit nach G ott" erschien 1990 eine umfassende Religionstheologie aus der Sicht der Zeugen Jehovas (im Folgenden: ZJ). ${ }^{56}$ Angesichts der Tatsache, dass in dieser Zeit bei den ZJ auch ansonsten eine etwas stärkere Auseinandersetzung mit der Welt („System der Dinge“) zu beobachten war, stellt sich bei diesem letzten Fallbeispiel die Frage, wie die Welt der Religionen in dieser Publikation wahrgenommen, analysiert und theologisch beurteilt wird.

A usgangspunk t: Angesichts der weltweiten, ganz unterschiedlichen Sichtbarkeit von Religionen bedürfe es genaueren „Wissens“, um zu mehr „Verständnis“ und „Toleranz" zu gelangen ${ }^{57}$ (5-8). Zentrale K riterien für eine Beurteilung der Religionen seien die „Früchte“ (Mt 7,17-20) im Leben (12). Viele Religionen bilden nämlich „schwerverständliche Theologien" aus oder rechtfertigen sogar Kriege und Gewalttaten: „Bekannt für Heuchelei auf diesem Gebiet sind die Länder der Christenheit" (14); - wobei die ZJ programmatisch zwischen der "Christenheit"58 und dem von Jesus eigentlich begründeten wahren „Christentum" unterscheiden (vgl. 235). - Zu fragen ist also, ob die Religionen „friedsame Früchte" hervorbringen (15). Rö 12,2 liefere die Maxime, sich „nicht nach dem System der Dinge" formen $\mathrm{zu}$ lassen sondern mit verwandeltem Geist alles zu ,prüfen' - und dabei helfe das „inspirierte Wort Gottes“ (zumal die älteren Bibel-Teile sogar die ältesten religiösen Schriften der Welt darstellten; 16f). D em Titel entsprechend liegt der theologische Ausgangspunkt in der Areopagrede des Paulus (Apg 17), der zufolge alle Menschen aus "einem Menschen“ stammen ${ }^{59}$ und - in Nationen über die Erde verteilt überall nach „G ott suchen“ (v. 27).

G liederung und E ntfaltung: Das Buch spannt den Bogen von Mythologie, Magie und Spiritismus über Hinduismus, Buddhismus, Taoismus/ Konfuzianismus, Shintoismus, Judentum, Christentum (hier aufgefächert in: Ursprünge, „Abtrünnigkeit“ und „Reformation"), Islam bis zur Frage nach der heutigen „Rückkehr zu dem wahren Gott" angesichts des wachsenden Unglaubens. - Die Darstellung beginnt zunächst mit der Frage nach dem A nfang der Religion bei den „primitivsten“, „unterentwickelten" Völkern (19), handelt hierfür kurz einige klassische evolutionistische Religionstheorien (Tylor, Marett, Frazer, Freud) ab und kritisiert deren Spekulationen als „reine Phantasie und Mutmaßungen“ (25): Die sog. „wissenschaftlichen“

\footnotetext{
56 Wachtturm Bibel- und Traktatgesellschaft (1990); die Seitenangaben oben (in Klammern) beziehen sich auf diese Publikation.

57 Mit explizitem Bezug auf Parrinder (1984) (die Publikation des britischen Religionsforschern wird mehrfach zitiert und scheint eine maßgebliche Hintergrundinformation darzustellen).

58 Die etablierten Kirchen konstituierten sich so als „Bereich sektiererischer Tätigkeit” (235).

59 Die Sprachverwandtschaft der Völker belege dies, wird im Rekurs auf die alte Publikation F. S. Dobbins, S. W. Williams, Story of the W orld's W orship, Chicago 1901, nahegelegt (31), die aber selbst mit biblisch-geschichtstheologischen Spekulationen vom einen Ursprung der Menschen operiert: „all religions grew out of one original system of worship" (s.d. 35).
} 
Versuche, traditionale Religionsformen in einen Urzustand zu projizieren oder „Religion wegzuerklären“ seien allesamt nicht überzeugend (26-27).

Allerdings, so wird in Stil einer A nalogierelation mehrfach im Buch konstatiert, gebe es viele verblüffende $\mathrm{G}$ emeinsamkeiten zwischen den Religionen:60 Fluterzählungen, Vorstellungen von einem goldenen Zeitalter, Mönchtum, Seelenvorstellungen, Himmel und Höllen (Jenseits), O pferhandlungen etc. - Interessanterweise werden diese Analogierelationen in zwei Richtungen weiterinterpretiert: (a) Goldene Zeitalter-Vorstellungen und Fluterzählungen sollen auf die (wahre) gemeinsame, biblisch tradierte Quelle (G en 1-11) vom gemeinsamen Ursprung in Babylon ${ }^{61}$ verweisen (harmonisierende Relationierung), während (b) die Vorstellungen von Himmel/ Hölle und Seele (u.ä.) insgesamt in den Bann einer distanzierenden Relationierung gestellt werden, mit der diese - geschichtlich angeblich miteinander zusammenhängenden - menschlichen E rfindungen 62 in den Religionen der Welt von der wahren Religion unterschieden werden. Beides belege aber, dass die Menschen vor ca. 4200 Jahren (also nach der Sintflut) in Babel/ Mesopotamien lebten, sich von dort aus über die Erde verteilten und dabei ihre jeweiligen Traditionen überall hin mitnahmen (vgl. Fazit, 68).

Trotz der 0.a. Abwehr evolutionistischer Religionsdeutungen werden in Kap. 4 (zu „Magie“ und „Spiritismus“) doch wieder ,animistische' Postulate aufgegriffen und auch (implizit, ohne direkte Nennung) Frazers bipolare Magie-Theorie rekapituliert, um die Suche nach Gott in "Geistern“ und sonstigen „übernatürlichen Mächten" darzustellen, wobei der Bogen über Astrologie, Omen und Mantik bis zu Vodoo und rituellen Tötungen gespannt wird - was zu der abschließenden Warnung führt, dass hier mitunter der „Widersacher" umgeht (1 Ptr 5,8).

Die D arstellung der großen Religionstraditionen ist relativ differenziert und detailreich. Der Hinduismus (Kap. 5, 95ff.) wird beispielsweise durch Formen gelebter Religiosität und stets reich bebildert dargestellt, die Abgrenzungsprobleme und Vielgestaltigkeit werden thematisiert, Jenseitsvorstellungen, Pantheon und wichtige Begriffe - sowie die Yoga-Wege - werden kurz erläutert (usw.). Dabei taucht u.a. die orientalistische Fiktion auf, „der Hindu neig[e] als Folge des Karmas zum Fatalismus" und predige „Toleranz" $(112,128)$. Die Reinkarnationsvorstellung erweise aber einen deutlichen Konnex mit der „alten babylonischen Vorstellung einer unsterblichen Seele" (114). Dies gereicht am Ende des Kapitels - trotz der Wertschätzung der letztlich "monotheistischen“ Grundlage im Brahman, sowie von Toleranz und Tierliebe - zu einer stärkeren selbstreferentiellen Abgrenzung, da die ZJ bekanntlich keine Vorstellung von Seele und Jenseits (Himmel/ Hölle) dulden.

60 Vgl. die bebilderte D arstellung zum Vergleich von Buddhismus und Katholizismus (33).

61 Vgl. die Grafik zu Ursprung und Ausbreitung der Menschheit von Mesopotamien aus (39), sowie das ganze Kapitel 3, „G emeinsamkeiten in der Mythologie“ (41ff.).

62 D enn nicht allen Mythen lägen „Tatsachen oder die Bibel zugrunde. Der Mensch hat sich auf seiner Suche nach Gott an einen Strohhalm geklammert und sich von der Vorstellung der Unsterblichkeit der Seele täuschen lassen" (52). 
Dies habe in Indien auch „einige denkende Menschen veranlasst“ zu zweifeln und den Buddhismus auf den Plan gerufen.

Auch hier bietet die Darstellung detailreiche Grundinformationen zum Buddhismus (vier edle Wahrheiten, achtgliedriger Pfad etc.), äußert sich zu Leben und Legende des Buddha und skizziert weitere Schulrichtungen (z.B. Zen, AmidaBuddhismus). Beobachtungen zur kritischen Bewertungen werden nur am Rande eingestreut - so z.B. hinsichtlich der Vorstellung, Erleuchtung aus eigener Kraft erreichen zu wollen (139), denn dies versetze den Menschen hoffnungslos in „Treibsand" (156).63 Nach der weitgehend sachlichen Darstellung kommt plötzlich ein ernüchterndes Fazit: „Das Ergebnis dieser egozentrischen und unabhängigen D enkweise ist ein wahrhaftes Labyrinth von Legenden, Traditionen, komplizierten Lehren“ - „offensichtlich führt also die Suche nach Erleuchtung ohne Gott nicht zum Erfolg“ (160).

Bei der D arstellung des Judentums überrascht, dass in diesem Kapitel eine jüdische Bibelübersetzung benutzt wird und nicht die „Neue-Welt-Übersetzung“ der Zeugen. Gemäß der selbstreferentiellen Bedeutung der Gottesprädikation „Jehova" wird die Entscheidung für das Nichtaussprechen des Gottesnamens aber als Fehlentscheidung beurteilt (225ff); außerdem sollten sich „aufrichtige Juden“ neu mit der Frage des Messias Jesus beschäftigen (234).

Während die o.a. Religionen weitestgehend sachlich dargestellt werden und die religionstheologischen Abgrenzungen nur am Rande eingestreut oder nur im Fazit prägnant erscheinen, wird das Christentum mit Ausnahme seiner Grundlage in Jesus von Anfang an sehr kritisch dargestellt - entlang der bereits erwähnten Leitdifferenz Christentum versus Christenheit. Die Einzelheiten zum Leben Jesu (Kap. 10) werden dann mit den typischen ZJ-Akzentsetzungen vorgestellt, während die Irrlehren und ,sektarischen' Erfindungen der „Christenheit" in einem eigenen Kapitel 11 mit der programmatischen Überschrift „Abtrünnigkeit - D er Weg zu Gott blockiert" (261ff.) angeprangert werden. Die Christenheit habe sich demnach von der heidnischen Welt verführen lassen: v.a. „Seelen“-Glaube und Trinitätslehre, Transsubstantiation, Institution des Papsttums, Einführung einer „Klasse der Geistlichkeit" (vgl. auch Konstantin als wichtiger Faktor für die Etablierung der Christenheit), mit unseligen Folgen wie Unterdrückung, Inquisition (usw.). - Im Gegensatz zu den anderen Religionen gerät die Darstellung des Christentums daher regelrecht zu einer A brechnung mit den Fehlern und theologischen Irrtümern der so genannten "Christenheit". - Im Falle des Islams kann dagegen z.B. der Schulterschluss mit dessen Ablehnung der Trinität gesucht werden (297).

D ie Überleitungen zu den Schlussabschnitten bieten Überblicke zum neuzeitlichen Unglauben: Der Angriff von Wissenschaft und Philosophie auf die Religion wird skizziert (allem voran Darwins Evolutionslehre) und die ZJ-Gegenposition entfaltet (im Sine von ,D ie Bibel hat doch recht' und Intelligent D esign). Aufrechte Zeugen wie Charles Taize Russel hätten dann mit der Etablierung der ZJ-

$63 \mathrm{Vgl}$. auch die Auseinandersetzung mit der buddhistischen Wiedergeburtslehre (151-153). 
G emeinschaft, die mit ihren Errungenschaften vorgestellt wird (344ff.), wieder die Möglichkeit der „Rückkehr zu dem wahren G ott" eröffnet (Kap. 15).

D as Schlussk apitel 16 („D er wahre G ott und D eine Zukunft“) bündelt den Ertrag in Anknüpfung an das Babylon-Thema vom Anfang und formuliert als religionstheologische Fazit, dass es sich bei den Religionsgemeinschaften um „Satans Weltreich der falschen Religion" handelt, das demnächst von Gott vernichtet wird, denn „Harmagedon ist nahe“ (370f.):

Wie wir in dem vorliegenden Buch von Anfang an gesehen haben, ziehen sich gemeinsame Fäden durch das G espinst der Religionen der Welt. Viele Religionen wurzeln in der Mythologie. Fast alle sind miteinander verknüpft durch den Glauben an eine angeblich unsterbliche Menschenseele, die nach dem Tod weiterleben und ins Jenseits oder in ein anderes G eschöpf übergehen soll. Viele haben den Glauben an einen schrecklichen ort der Q ual und Folter, Hölle genannt, gemeinsam. Andere sind durch den alten heidnischen Glauben an Triaden, D reiheiten und Muttergöttinnen miteinander verbunden. Daher ist es nur passend, sie unter dem einen zusammengesetzten Sinnbild zusammenzufassen: ,Babylon die Große', die Hure (Offenbarung 17:5). (369)

A uswertung und A nalyse. - D ie D arstellung scheint sich an Standarddarstellungen zu sog. „Weltreligionen“ anzulehnen, denn es werden konventionelle Themenschwerpunkte und einschlägige Basisinformationen abgehandelt, und zwar weitgehend sachlich-deskripitv. Nur bestimmte Themen, die ZJ-spezifisches Interesse wecken, werden besonders kommentiert oder kurz in den Fokus gerückt. Am schlechtesten schneidet die Christenheit in der Darstellung ab, denn die selbstreferentielle A bgrenzung ist hier von Anfang an besonders nötig, da sie für die ZJ-Perspektive eine systemk onstituierende Rolle spielt. Streckenweise liest sich die Publikation sonst fast wie eine einfache, allgemeinverständlich gehaltene Einführung in religionskundliches Basiswissen, wie sie für Schule oder Erwachsenenbildung konzipiert sein könnte mit durchaus informativen Tafeln und Illustrationen. Manche der ZJ-Kommentare tauchen nur am Rande auf, fast wie in Klammern gesetzt, und fallen daher erst bei eingehender Lektüre stärker auf. Legt man eine dem Genre der Veröffentlichung angemessenen Maßstab zugrunde, sind massivere Falschmeldungen sogar relativ selten. ${ }^{64}$ D ie wertenden Passagen spannen einen Bogen von der babylonischen Sprachverwirrung bis zur Rückkehr zum wahren Gott durch die restituierte Lehre der wahren Zeugen.

Wenn man die Untertitel der Kapitelüberschriften genauer betrachtet, wird klar, dass es sich in den Religionen immer nur um eine „Suche nach Gott" handelt, keineswegs um ein ,Finden' (Ausnahme Jesus und die ZJ). Die Gemeinsamkeiten werden per Analogierelation (a) einerseits in einigen (aus ZJ-Perspektive) devianten Glaubensvorstellungen der Anderen gefunden (Seelenvorstellungen, Triaden, Höllenregionen). Argumentativ werden diese Religionselemente in eine distanzierende Relationierung gestellt und zugleich horizontalisiert, d.h. als menschliche und intra-

64 Wie z.B. die falsche Meinung, Tezcatlipoca sei der aztekische „Sonnengott“ gewesen (59). 
mundane Produkte angesehen, in denen - um nochmals mit $\mathrm{E}$ vangelii $\mathrm{N}$ untiandi zu reden - die Menschen zwar ihre Hände suchend nach Gott ausstrecken, ihn aber nicht erreichen. Andere $\mathrm{G}$ emeinsamkeiten aus den Analogierelationen werden dagegen (b) als Niederschlag von Reminiszenzen biblischer Wahrheiten (Flutmythen, Erinnerung an ein paradiesisches Goldenes Zeitalter) aufgefasst und im Sinne einzelner harmonisierender Relationierungen (auf Elementebene) weiterverarbeitet (vgl. auch den Schulterschluss mit der islamischen Trinitätskritik). Diese wenigen Harmonisierungen bezüglich einzelner Elemente ließen sich zu einer partiellen hierarchisch-inklusiven Relationierung (auf Systemebene) zusammenaddieren, die allerdings zugleich wieder von stramm exklusiven $\mathrm{G}$ eltungsbehauptungen der ZJ begleitet und kontrastiert wird.

Interessant ist hierbei dennoch, dass die Darstellung der Religionen und ihrer Glaubensdetails mehrfach so relativ sachlich beschreibend erfolgt (ist dies als Beleg für das ,kommunikativere' Eingehen der ZJ auf die ,Welt' zu werten oder handelt es sich hier nur um einen Reflex der im Hintergrund konsultierten D arstellungswerke zur Welt der Religionen mit ihrem deskriptiven G estus?). Insgesamt wird aber nicht nur eine A ristotelianisierung der anderen Religionen vorgelegt, die mit dem platonisierenden Schema einer weitgehend exklusiven Selbstdeutung aus der Sicht des ZJ-Christentums kontrastiert wird, denn letztlich werden die so vergegenwärtigten Religionsgebilde in den Schlussabschnitten - auf rund zwei Seiten (369f.) fast überraschend und kaum vermittelt - ganz auf ein teuflisches Wesen reduziert: Diese abschließende dämonologisierende Reduktion identifiziert sie in der religionstheologischen Deutungsperspektive als „Hure Babylon“ und "Satans Weltreich der falschen Religion“. Doch somit spannt sich der Bogen von der heillosen babylonischen Sprachverwirrung über die historischen Verirrungen der einzelnen Religionen zurück zum vernichtenden Endurteil über die gesamte Welt der Religionen unter dem dämonisierenden Stichwort „Babylon“.

An diesem Beispiel lässt sich sehr gut illustrieren, wie sich mehrere Wahrnehmungsebenen überlagern können und wie sich deskriptive, wertende und gegenläufig wertende Zugriffe mischen und ergänzen, um eine selbstreferentielle Positionsbestimmung gegenüber religiöser Alterität differenziert auszuformulieren; die Wahrnehmung des Anderen kann dabei zugleich sachlich und dann wieder stärker interpretationsimprägniert erfolgen.

\section{Abschließende Bemerkungen und weiterführende Thesen zur Religionstheologie}

Das letzte Beispiel zeigte außerdem, dass die konkrete G rammatik der interreligiösen F remdwahrnehmungen meist weitaus komplexer ist, als es das simple tripolare Klassifikationsmodell Exklusivismus, Inklusivismus und Pluralismus suggeriert. Religiöse Systeme präsentieren sich historisch dennoch in der Regel als einander weitgehend ausschließende, exklusive Formen der Kontingenzbewältigung. Vom Buddhismus 
bis zu Scientology gilt: „A claim to uniqueness is not unique” (Wilfred C. Smith). Von religiös pluralen Kontexten dazu - mehr oder weniger unfreiwillig - herausgefordert, reagieren Religionen auf interreligiöse Infragestellungen zunächst mit inklusiven Eingemeindungsstrategien und der Einräumung bescheidener homelands für andersreligiöse Traditionen bzw. Traditionselemente im Rahmen der intern vorfabrizierten kognitiven Landkarten, die im Stil eines überlegenen "got the same back home but bigger" entfaltet werden, aber dadurch selten in der Lage sind, ,lebendige' Wirklichkeiten zu vermitteln (demgegenüber gilt daher die deutliche Warnung: map is not territory).

Die oben dargestellten religionswissenschaftlichen und religionsgeschichtlichen Einsichten lassen sich innerhalb einer christlich-theologischen Perspektive zu wichtigen Folgerungen für eine „Theologie der Religionen“ weiterverarbeiten. Indem ich dabei den Standortwechsel von der religionswissenschaftlichen Deskription und Analyse zur (religions-)theologischen Programmatik vollziehe, möchte ich dies zum Abschluss wenigstens noch kurz thesenartig skizzieren.

These I: In den meisten Fällen interreligiöser Fremdwahrnehmungen überwiegt eine defizitäre, eher karikaturenhaft verzerrte, immanentistische oder mitunter sogar monströs und dämonisch entstellte Repräsentation des religiös A nderen und Fremden. W irk liche E mpathie hat in den Rekonstruktionen grenzüberschreitender $\mathrm{W}$ ahrnehmungen des religiös A nderen und Fremden daher ex tremen Seltenheitswert.

Ein dezidierter religiöser Pluralismus ist dagegen eine zunächst durch die Moderne erzeugte Metaperspektive auf Religion(en), die auf der Ebene religiöser Systeme eher dysfunktional anmutet. Religionsgeschichtlich betrachtet hatte sie daher auch geringe Selektionspräferenzen und mit ihrer Etablierung neuer „inklusiver O peratoren" (The Real, Transœndence, Soteria), anhand derer man sich der Religionsgeschichte deutend bemächtigt, unterliegt der religionstheologische Pluralismus häufig selbst einem Inklusivismusverdacht höherer O rdnung.

These II: Meiner A nsicht nach bleibt daher ein faktischer Inklusivismus innerhalb religiöser Perspek tive letztlich unentrinnbar; sogar dezidiert pluralistische V ersuche einer religiösen R eligionsdeutung weisen diese Struk tur auf. A uf der E lementebene sind "pluralistische" (harmonisie rende) Teildeutungen anderer Religionen gut möglich und können sogar unbedingt nahe liegend erscheinen. - A ber: W elche andere Religion Rx (als ausdifferenzierte $\mathrm{G}$ esamtgröße) käme nach welchen Kriterien für eine bestimmte religiöse D eutungsperspek tive R 1 als gänzlich "gleichwertig" in F rage (außer im F alle einer neuen und umfassend synk retistischen R eligion)?

Wenn man daher als ,punktueller Pluralist' (im Sinne der Relationierungen auf Elementebene) imponierende Wahrheitserschließungen oder gar Heilsmöglichkeiten (?) bei Menschen anderen G laubens erlebt und erkannt zu haben glaubt, wird man diese - religiös gesehen - letztlich doch immer wieder nur ,inklusivistisch' rekonstruieren können (und zwar nicht nur aus hermeneutischen G ründen). - M etaphorisch gewendet: Religiöse D eutungen anderer Religionen stehen in der Spannung, sich 
vielleicht wegen empirischer Einsichten aus interreligiösen Begegnungen in die plötzlich naheliegende Möglichkeit eines Pluralismus ,verliebt' zu haben, faktisch aber nach wie vor mit dem Inklusivismus ,verheiratet' zu sein. Ein durch solche induktive Erschließung religiöser Alterität verantworteter und informierter Inklusivismus, der im Dialog „mit" den Anderen nach und nach verantwortet, durchgearbeitet und entwickelt wurde, erscheint zwar formallogisch zunächst völlig gleich, ist aber in der inhaltlich-differenzierten und sachhaltigen Erfassung sehr deutlich zu unterscheiden von einer rein deduktiv-inklusivistischen Aussage, die „über" die Anderen hinwegtheoretisiert und theologisiert. Sie lässt sich daher auch perspektivenübergreifend weitaus besser kommunizieren (z.B. als ein unentrinnbar wechselseitiger Inklusivismus, der im Dialog vermittelt werden kann).

These III: Religiöse Traditionen, die systemimmanent bereits mit grundlegenden ,U ngewissheitsvorbehalten' eschatologischer oder epistemologischer $\mathrm{N}$ atur rechnen, haben es interreligiös leichter, positive $\mathrm{V}$ erhältnisbestimmungen zum religiöse A nderen zu entwick eln als Traditionen, die von einem ausgesprochen fest gefügten 0 ffenbarungs- oder Traditionsdepositum ausgehen und sich daher auf die applikative $\mathrm{V}$ ollstredkung dieses, absoluten W issens' zurückziehen können (vgl. auch analog die F ormen fundamentalistischer Reak tionsbildung und R hetorik).

Diese These wäre im Blick auf die jeweiligen Selbstrelativierungsstrategien in einzelnen Religionen zu konkretisieren, mit denen wichtige ,Ungewissheitsvorbehalte' gegenüber letztgültigen Erkenntnissen und Aussagen - und zwar nicht nur über die religiöse Alterität - eingeräumt werden (z.B. eschatologische oder epistemologische Vorbehalte). Diese eröffnen meist behutsamere Erschließungsräume für eine differenzierte interreligiöse Fremdwahrnehmung. - Wichtiger als der immer wieder neue Streit um die Möglichkeit einer dezidiert pluralistischen Perspektive als religiöse oder theologische Möglichkeit (auf Systemebene!) ist jedoch das Bemühen um interreligiöse Verständigung: Annäherungen und besseres Verstehen trotz deutlicher und unverhohlener D ifferenzen - Toleranz trotz einzelner Antipathien, bleibender Unterschiede und konkurrierender Wahrheitsansprüche - sowie einzelne Entdeckungen überraschend eindrücklich und positiv anmutender Analogien und attraktiver Elemente im Anderen.

These IV : D ie Ü berwindung der inhärenten, geradezu "chronischen A llergie" gegenüber andersreligiösen Positionen und die Infragestellung der hermeneutischen $\mathrm{G}$ efräßigk eit des selbstreferentiellen A ssimilierens und ,A bwick elns' des A nderen gelingt nicht über abstrak te ,R eligionstheologien', sondern nur einem sehr aufwändigen und prinzipiell unabschließbaren V erständigungsprozess von A ngesicht zu A ngesicht.

Die Religionswissenschaft kann mit ihrer schmerzhaften, aber nachhaltig realisierten Einsicht in das Scheitern sämtlicher evolutionistischer (Religions-) G eschichtskonstruktionen, globaler Religionstheorien und sogar scheinbar ,selbstverständlicher' terminologischer Einzelkonzepte in einer empirischen, vielgestaltigen Welt der Religionen eine enorm wichtige L ernerfahrung in die religionstheologischen D ebatten einspeisen: 
Wenn sogar diese eher desk riptiv orientierten Versuche globaler D eutungen der Religionswelt häufig interk ulturell gescheitert sind, um wie viel mehr verringern sich dann die perspektivenübergreifenden Plausibilitäts-, Applikations- und Verständigungschancen der genuin religiös bzw. theologisch motivierten Religionstheorien und Religionstheologien - v.a., wenn sie (wie oben dargestellt und bei den ZJ beispielhaft konkretisiert) oft sehr deduktiv aus binnentheologischen Selbstreferenzen abgeleitet werden und sich nicht einer dichten Auseinandersetzung im Feld verdanken - d.h. konkret und induk tiv im Dialog mit M enschen anderen G laubens entwickelt wurden.

These IV : D ie immer wieder zu beobachtende, dominante E ngfiuhrung des interreligiösen D ialogs und der religionstheologisch ,positiveren' E inlassungen auf die sog. „W eltreligionen“ ist zu überwinden und hinsichtlich einer nachhaltigen Berück sichtigung traditionaler und neuer Religionsk ulturen zu ergänzen, die jenseits von Begriffen wie "Magie" und "Sekte" mit derselben $\mathrm{H}$ altung anzusprechen sind wie die etablierten $\mathrm{G}$ roßstraditionen. Besonders im Blidk auf eine differenzierte W ahrnehmung alternativreligiöser und neureligiöser $\mathrm{G}$ emeinschaften herrschen nach wie vor extreme religionstheologische D efizite, da der theologische D isk urs - ganz zu schweigen vom offentlichen - immer noch von pauschalen $\mathrm{V}$ orurteilen gegenüber solchen $\mathrm{G}$ ruppen geprägt ist (,G efahrendiskurs').

Aufzugeben sind Religionskonstruktionen, die sich primär (bzw. in einzelnen positiven D eutungen womöglich sogar nur) auf die immer wieder so genannten „Weltreligionen" beziehen und dagegen die vielgestaltige Welt der traditionalen (ethnischen) Religionen, aber auch der neuen Religionen und neuen religiösen Bewegungen entweder ganz ausklammem oder ihr nur einen unbedeutenden (bzw. pauschal minderwertigen oder gänzlich negativ konnotierten) Platz - gleichsam am ,Katzentisch' - in der allgemeinen Religionsgeschichte zuweisen. Solche Konstrukte bilden lediglich eine hegemoniale D iskurskonvention ab (Machtdiskurs der „Weltreligionen“ als dialogue of the fittest), die weder religionswissenschaftlich angezeigt noch (geschichts-) theologisch vertretbar ist. D ies erfordert eine nachhaltige Eliminierung stigmatisierender Begriffe, die in theologischen Diskursen immer wieder reüssieren: Traditionale Religionen werden gerne noch mit "Animismus“, „Mythologie“ und „Magie“ in Verbindung gebracht und somit unterschwellig konfrontiert, oder neureligiöse Bewegungen werden nach wie vor mit dem stigmatisierenden „Sekten“-Begriff belegt. Ge rade letzterer verbietet sich heute vollständig (abgesehen von einem betonten, eingeschränkt sozialwissenschaftlichen Sprachgebrauch zur Bezeichnung einer be stimmten religiösen 0 rganisationsform) und hat nicht nur aus politischen 65 , sondern auch aus theologischen Stellungnahmen 66 nachhaltig zu verschwinden, zumal er in

65 Vgl. programmatisch und unmissverständlich den Endbericht der Enquete-Kommission „Sogenannte Sekten und Psycho-Gruppen“, D eutscher Bundestag, 13. Wahlperiode, Drucksache 13/ 10950, Bonn 1998 [http:/ / dip21.bundestag.de/ dip21/ btd/ 13/ 109/ 1310950.pdf]. Vgl. den gesamten Abschnitt 2 (ebd. 17-22) für eine umsichtige Diskussion der Terminologie, sowie den sehr guten, konzisen Überblick zu churches, sects, alts im Eingangskapitel zu D awson (22006).

66 Vgl. A. Fincke, „Was ist eine Sekte?", Faltblatt aus der Reihe EZW-Kompakt-Infos, 2007 (online unter: www.ekd.de/ ezw/ dateien/EZW_KI_Was_ist_eine_Sekte_4_2007.pdf), der am Ende zu der 
der Öffentlichkeit stets im Sinne ,konfliktträchtiger (Pseudo-) Religion' gehört wird. Er insinuiert aber auch innerhalb des theologischen Sprachgebrauchs ständig pauschale Falschheit, inhärente Konflikträchtigkeit und mehrdimensionale D evianz, knüpft heimtückisch an den öffentlich-medialen ,Gefahrendiskurs' an und verstellt somit offenes $G$ espräch und kritische Auseinandersetzung, wie sie kontextuell erforderlich wären.

D ies wäre dringend für Religionsunterricht und Erwachsenenbildung fruchtbar zu machen, da die pauschalen ,Sekten'-D iskurse in vielen Unterrichtsmaterialien und Medien sogar noch in elementarisiert-verdichteter Form ,durchgereicht' werden und Vorurteile weiter zementieren, ${ }^{67}$ wenn sie z.B. auf unsinnigen Leitdifferenzen wie „Sekte“ versus „Religion“ beruhen. Hier müsste theologisch noch einmal ausdrücklich an die Verortung der Dialog-Theologie im biblischen $\mathrm{G}$ rundverbot der L üge erinnert werden (Ö RK-G uidelines). Selbst wenn man nur die Nähe und Ferne des Spektrums „postchristlicher" Gruppen oder sog. „Sondergemeinschaften“ zum großkonfessionellen Christentum kritisch bestimmen möchte, sollte dies in einem programmatischen Verzicht auf das „Sekten“-label erfolgen; hier sind andere, unpolemische Formen der Differenzthematisierung zu suchen, mit denen sachliche Argumente und eine verantwortliche theologische Auseinandersetzung ausgedrückt werden können.

\section{Literaturangaben}

Ahmad, Hazrat Mirza G hulam (1988): Jesus starb in Indien. Frankfurt/ M.: Verlag D er Islam.

Ders. (Hg.) (1992): Jesus starb nicht am Kreuz. D rei V orträge. Frankfurt/ M.: Verlag D er Islam.

Berner, Ulrich (1979): „D er Begriff ,Synkretismus' - ein Instrument historischer Erkenntnis?" In: Saeculum 30 (1979), 68-85.

Ders. (1982): Untersuchungen zur V erwendung des Synk retismus-Begriffes (GOF.G 2). Wiesbaden: Harrassowitz.

programmatischen Forderung gelangt: „Im kirchlichen oder staatlichen Kontext sollte dieser Begriff [Sekte] jedoch vermieden werden." D em kann ich nur zustimmen. - Im Kontext der Weltanschauungsarbeit exstieren mitunter gekünstelt wirkende Versuche, eine altertümliche Sektenterminologie nach wie vor ,diskursfähig' zu halten. Religionswissenschaftlich unstatthaft und theologisch unredlich wäre es, hierbei die sozialwissenschaftliche "Reinigung' des Begriffs so zu marginalisieren, dass scheinbar Raum für theologisch motivierte, aber kurzschlüssige Anknüpfungen an eine SektenBegrifflichkeit erwirkt wird, die sowohl religionswissenschaftlich wie theologisch überholt ist. 67 Vgl. meinen Beitrag „Scientology“ [im Religionsunterricht] zu R. L achmann, M. Rothgangel, B. Schröder (Hg.), Christentum und Religionen (TLL 5), Göttingen 2009 (z.Zt. im D ruck). 
Bernhardt, R. (2004): „Grundlinien des Gesprächs zwischen Juden, Christen und Muslimen“. In: 0 ecumenica 16 (2004), 5-13 (www.theologie.uni-hd.de/ oek/ oekfreunde/ oecum-04.doc).

Boone, Elizabeth (1989): Incranations of the A ztec Supernatural: The Image of $\mathrm{H}$ uitzilopochtli in Mexioo and Europe. Philadelphia: American Philosophical Society, 67-83.

v. Brück, Michael und Whalen Lai (1997): Buddhismus und Christentum. G eschichte, Konfrontation, D ialog. München: C. H. Beck.

Buttaroni, Susanna, Stanislaw Musial (Hg.) (2003): Ritualmord. Legenden in der E uropäischen $\mathrm{G}$ eschichte. Köln: Böhlau.

Church of Scientology International (Hg.) (1993): H ass und Propaganda - sank tioniert und betrieben von Medien und Behörden. D okumentation einer H etzkampagne gegen die Scientology-G emeinschaft. Los Angeles: Church of Scientology International.

Colpe, Carsten (1987): Art. "Synkretismus“. In: Mircea Eliade (Hg.): E ncydopedia of R eligion. Vol. 14. New York/ London: Macmillan, 218-227.

D awson, Lorne (22006): C omprehending C ults. The Sociology of N ew Religious M ovements. Oxford: Oxford University Press.

D ehmel, Paula und Richard D ehmel (1990): Fitzebutze. A llerhand Schnickschnack für Kinder. Hrsg. von E. K reidolf. Frankfurt/ M. 1984.

D ehmel, Richard (1907): Fitzebutze. Traumspiel in 5 A ufzügen. Berlin: S. Fischer.

Erb, Rainer (1993): D ie L egende vom Ritualmord. Berlin: Metropol.

Feldtkeller, Andreas (1992): „D er Synkretismus-Begriff im Rahmen einer Theorie von Verhältnisbestimmungen zwischen Religionen“. In: E vTheol 52 (1992), 224-245.

D ers. (1993): Identitätssuche des syrischen Christentums. Mission, Inkulturation und Pluralität im ältesten H eidenchristentum. Göttingen: Vandenhoek \& Ruprecht.

D ers. (1994): Im Reich der Syrischen Göttin. E ine religiös plurale Kultur als U mwelt des frühen C hristentums. G ütersloh: G ütersloher Verlagshaus.

Figl, Johann (1993): D ie Mitte der Religionen. Idee und Praxis universalreligiöser B ewegungen. D armstadt: Wissenschaftliche Buchgesellschaft.

Fincke, A. (2007): „W as ist eine Sekte?" Faltblatt aus der Reihe EZW-KompaktInfos. (online unter: www.ekd.de/ ezw/ dateien/ EZW_ KI_Was_ist eine Sekte_4_2007.pdf)

Garbe, Richard (1988): Die Bhagavadgitā. Darmstadt: Wissenschaftliche Buchgesellschaft. (Leipzig 21921). 
Grünschloß, Andreas (1994): „Interreligiöser Dialog in kirchlich-institutionellem Kontext". In: J. A. van der Ven, H.-G. Ziebertz (Hg.): Religiöser Pluralismus und interreligiöses Lernen (Theologie und Empirie 22). Weinheim/Kampen: D eutscher Studienverlag, 113-167.

Ders. (1999): Der eigene und der fremde Glaube. Studien zur interreligiösen Fremdwahrnehmung in Islam, H induismus, Buddhismus und Christentum (HUTh 37). Tübingen: Mohr/ Siebeck.

Ders. (2000): „Zur Thematisierung des religiös Fremden im frühen Buddhismus (Pali-Kanon)“. In: D. Becker (Hg.): Mit dem Fremden leben. Perspektiven einer Theologie der Konvivenz (FS Theo Sundermeier). Band 1: Religionen - Regionen. Erlangen: Missionswissenschaftliche Forschungen, 81-92.

Ders. (2002): „Interreligiöse Fremdwahrnehmung als Thema von Religionswissenschaft und Theologie“. In: A. Schultze, R.v. Sinner, W. Stierle (Hg.): „V om Geheimnis des Unterschieds ..." - D ie W ahrnehmung des Fremden in Ö kumene, M issions- und R eligionswissenschaft. Münster: LIT Verlag, 37-61.

Ders. (2006): „Brutale Menschenschinder und „Edle Wilde’: Repräsentationen aztekischer Religion“. In: Friedrich Schweitzer (Hg.): Religion, Politik und G ewalt. G ütersloh: Gütersloher Verlagshaus.

Ders. (2008): „Buddhist-Christian Relationships“, in: P. Schmidt-Leukel (Hg.): Buddhist A ttitudes to 0 ther Religions. St. Ottilien, 237-268.

Ders. (2009): „Was ist ,Fundamentalismus”? Zur Bestimmung von Begriff und G egenstand aus religionswissenschaftlicher Sicht". In: Tim Unger (Hg.) (2009): Fundamentalismus und Toleranz. Hannover: Lutherisches Verlagshaus, 163-196 (V orgängerfassung online unter: www.gwdg.de/ agruens/ fund/ fund.html).

Ders. (2009): „Scientology“. Zu R. Lachmann, M. Rothgangel, B. Schröder (Hg.): Christentum und Religionen (T L L 5). Göttingen (z.Zt. im D ruck).

Hapatsch, Hischam A. (2007): D ie Rezeption von Kirche und Christentum im deutschsprachigen Buddhismus. Hamburg: Verlag Dr. Kovac.

Hutter, Manfred (1994): D ie Bahá'í - Geschichte und L ehre einer nachislamischen W eltreligion. Marburg: Remid.

Ders. (2009): H andbuch Baha'i: G eschichte - Theologie - Gesellschaftsbezug. Stuttgart: Kohlhammer.

Khoury, Adel-Theodore (1969): D er theologische Streit der Byzantiner mit dem Islam. Paderborn: Schöningh.

Kippenberg, Hans G . \& Tilman Seidenstücker (Hg.) (2004): T error im D ienste G ottes. D ie "G eistliche A nleitung" der A ttentäter des 11. September 2001. Frankfurt/ M.: Campus Verlag. 
Klatt, Norbert (1988): Lebte Jesus in Indien? Eine religionsgeschichtliche Klärung. Göttingen: Wallenstein.

Küntzel, Matthias (2003): D schihad und Judenhaß. Ü ber den neuen antijüdischen Krieg. Freiburg: Ça ira Verlag.

Leong, Kenneth S. (2000): Jesus - der Z enlehrer. D as H erz seiner L ehre. Freiburg: Herder Verlag.

Marty, Martin. E. \& R. Scott Appleby (Hg.) (1995): F undamentalisms Comprehended. Chicago/ London: University of Chicago Press.

Mylius, Klaus (1997): Die Bhagavadgitā. München: dtv.

Parrinder, G eoffrey (1984): W orld Religions: From A ncient H istory to the Present. New York: Facts on File.

Poggendorf-Kakar, Katharina (1999): D er G ottmensch aus Puttaparthi. E ine A nalyse der Sathya-Sai-Baba-Bewegung und ihrer westlichen A nhänger. Hamburg: Rowohlt.

Pye, M. (1999): „Methodological Integration in the Study of Religions“. In: T. Ahlbäck (Hg.): A pproaching Religion - Part I. Åbo, 189-205.

Ders. (2000): „Participation, Observation and Reflection“. In: N. G. Holm et al. (Hg.): E thnography is a $\mathrm{H}$ eavy Rite. Studies of Comparative R eligion in $\mathrm{H}$ onor of Julia Pentikäinen. Âbo, 64-79.

Schmidt-Leukel, Perry (1997): Theologie der Religinen: Problem - Optionen - A rgumente. München-Neuried: Ars Una-Verlag.

D ers. (1998): „D as Problem divergierender Wahrheitsansprüche im Rahmen einer pluralistischen Theologie der Religionen“. In H.-G. Schwandt (Hg.) (1998): Pluralistische Theoogie der Religionen - eine kritische Sichtung. Frankfurt/ M.: Lembeck, 39-58.

Schmidt-Leukel, Perry, Thomas J. Götz, Gerhard Köberlin (Hg.) (2001): Buddhist Perceptions of Jesus. St. Ottilien.

Shoghi Effendi (Hg.): Bahá'u'lláh - Ährenlese. Eine A uswahl aus den Schriften Bahá'u'lláhs. Hofheim-Langenhain 31980.

Sievernich, Gereon (1990): A merica - de Bry, 1590-1634: A merik a oder die N eue W elt. D ie ,E ntdeckung' eines Kontinents in 346 Kupferstichen. Berlin/ New York: Casablanca.

Smith, Wilfred C. (1978): The Meaning and End of Religion. San Francisco: HarperSanFrancisco. (mehrere Auflagen; 1. Aufl. New York 1963).

Stark u.a. (2000): Fitzebutze: 100 Jahre modernes Kinderbuch. Marbach: Deutsches Literaturarchiv. 
Süss, Joachim (1996): Bhagwans E rbe. D ie 0 sho-B ewegung heute. München: Claudius.

Theologischer Konvent Bekennender Gemeinschaften (Hg.) (1999): Kein andrer Name! (Apostelgeschichte 4,12): Theologische Erklärung zur Beurteilung der Religionen im Licht des Evangeliums. Krelingen/G omaringen. (online: www.institut-diakrisis.de/ kanerkl.pdf).

Towfigh, Stephan Anis, Wafa Enayati (2005): D ie Bahá'í-Religion. E in Überblick. München: Beck.

Wachtturm Bibel- und Traktatgesellschaft (Hg.) (1990): D ie Suche der M enschheit nach $\mathrm{G}$ ott. Selters/ Taunus.

Watt, William. M. (1988,1992): D er E influß des Islam auf das europäische Mittelalter. Berlin: Wagenbach.

Wißmann, Hans (1981): Sind doch die Götter auch gestorben. D as Religionsgespräch der Franziskaner mit den A ztek en von 1524. G ütersloh: G ütersloher Verlagshaus Gerd Mohn. 



\title{
Interkulturelle Interaktion: Heterogenität als Chance?
}

\author{
H iltraud Casper-H ehne
}

\section{Interkulturelle Kommunikation - Ausgangspunkte}

D er UN-Generalsekretär Kurt Waldheim trifft Anfang Januar 1980 in Teheran ein. Er beabsichtigt, sich um die Freilassung von US-amerikanischen Botschaftsangehörigen zu bemühen, die von iranischen Studenten als Geiseln festgehalten werden. Fernsehen und Rundfunk berichten über das Ereignis und zeigen ein aktuelles Interview mit dem Generalsekretär. „Er komme als Vermittler“, so Kurt Waldheim in den iranischen Medien, „auf der Suche nach einem Kompromiss." Wenige Stunden nach Ausstrahlung dieser Sendung erfolgen im Iran massive D emonstrationen, das Auto Waldheims wird mehrfach mit Steinen beworfen. Der UNGeneralsekretär beendet seine Mission am 4. Januar 1980 ohne konkrete Ergebnisse.

D ie interkulturelle Kommunikationsforschung führt diese Situation als ein Beispiel dafür an, dass die Interaktion zwischen Angehörigen verschiedener Kommunikationsgemeinschaften bzw. Menschen verschiedener kultureller Herkunft, Identität oder Zugehörigkeit misslingen kann. Waldheims politischer Apparat, so die Interpretation, hätte nicht bedacht, dass im Iran ein völlig anderes Begriffsverständnis von „Kompromiss" und „Vermittler" herrsche.

„Kompromiss" werde dort konnotiert mit „Herabsetzung der eigenen Position“ und ein Vermittler sei „eine Person, die sich uneingeladen in etwas hineindränge." D ie beschriebene Interaktion habe damit - so die Forschung - zumindest 
dazu beigetragen, den schon bestehenden Konflikt zwischen beiden Staaten deutlich eskalieren $\mathrm{zu}$ lassen.

D erartige Wahrnehmungen, vor allem in Politik und Wirtschaft bildeten den Ausgangspunkt für das Interesse an der Thematik der interkulturellen Kommunikation, seiner Erforschung und seiner Vermittlung.

So beginnt diese vor allem in den 60er Jahren in den USA im Zuge des PeaceCorps-Programms, das Tausende von Freiwilligen zur so genannten Entwicklungshilfe in die 3. Welt entsandte und das vor Ort zahlreiche Kommunikationsprobleme aufwarf. Im weiteren Verlauf der Entwicklung befördern die Civil-RightsBewegung, die Ausweitung der internationalen Handelsbeziehungen und die zunehmende kulturelle Vielfalt in den Großstädten der USA die Intensivierung der Forschung sowie - darauf aufbauend - die Entwicklung und Durchführung von interkulturellen Trainings.

Grundlage des bundesdeutschen Interesses bildeten Fehlschläge in der Entwicklungszuasmmenarbeit der 60er Jahre sowie Kommunikationsschwierigkeiten allochtoner Arbeitnehmer. Einen ersten Schwerpunkt der Forschung in Deutschland stellten deshalb Mitte der 80er Jahre insbesondere institutionelle Kommunikationssituationen zwischen Deutschen und Angehörigen sprachlicher Minderheiten dar (etwa Griechen, Türken etc.) (z.B. Rehbein 1986; Redder/ Rehbein 1987; Hinnenkamp 1989; vgl. Überblick bei Rost-Roth 1994). Mittlerweile begründen die internationalen Handelsbeziehungen, die rasante Entwicklung des europäischen Binnenmarktes und die wachsende Zahl von Zuwanderern die zunehmend systematische Beschäftigung mit interkultureller Kommunikation.

\section{Interkulturelle Kommunikation: Missverständnisse}

Nicht immer werden Missverständnissen so weit reichende Folgen angelastet, wie im oben dargestellten Fall, doch ist sich die interkulturelle Kommunikationsforschung zum Großteil einig, dass unterschiedliches sprachliches und kulturelles Hintergrundwissen zu großen Kommunikationsstörungen führen kann. Und so hat sich dieser Forschungszweig in den letzten 20 Jahre vor allem auf die Untersuchung von interkulturellen Missverständnissen konzentriert. Interkulturelle Missverständnisse werden häufig sogar als das Legitimationsobjekt zur wissenschaftlichen Bearbeitung des Phänomens der interkulturellen Kommunikation herangezogen (Busch 2003: 3).

Im Folgenden soll noch einmal in groben Zügen nachgezeichnet werden, zu welchen Ergebnissen die Forschung gelangte, um diese anschließend noch einmal kritisch zu hinterfragen. 


\subsection{Kommunikative $\mathrm{G}$ attungen als Rahmen kultureller Handlungen}

Als erster Schritt soll dazu das Konzept der kommunikativen Gattungen eingeführt werden, um an diesem entlang die Forschungsergebnisse zu reflektieren. So kann man davon ausgehen, dass fast jeder Mensch zumindest in Bezug auf seine Muttersprache und Kultur mehr oder weniger genau weiß, welcher Rahmen für das sprachliche Verhalten in der einen oder anderen spezifischen Situationen vorhanden ist. Entsprechend wird bei einer Vortragsveranstaltung meistens ein Moderator den Referenten bzw. die Referentin einführen (dies mit spezifischen Textteilen, z.B. zu Thema des Vortrags und Biographie), dieser Einführung folgt zumeist ein monologischer Teil, d.h. der Vortrag mit besonderen Teiltexten und mit spezifischen Strukturen, und daran kann sich eine öffentliche D iskussion anschließen, in der spezifische Fragetechniken verwendet werden (D efinitionen klären lassen, Lösungsvorschläge abfragen etc.). Bekannt ist auch, dass der Vortrag wissenschaftssprachliche Elemente und eher weniger alltagssprachliche Formulierungen enthält.

D iese Rahmen für das sprachliche Verhalten werden in der Linguistik auch „kommunikative Gattungen“ genannt. Es sind typische Muster, nach denen sich Handlungsentwürfe richten können (Winter 2003: 218). Kommunikative Gattungen gelten als historisch und kulturell spezifische, gesellschaftlich verfestigte und formalisierte Lösungen kommunikativer Probleme (Luckmann 1986). Die kommunikativen Gattungen determinieren aber keine kommunikativen Vorgänge, sie bieten lediglich einen Rahmen zur O rganisation und zum Verständnis (Goffmann 1977), der jeweils spezifisch ausgestaltet werden kann. Das Wissen um diese Rahmen gehört - in unterschiedlicher Ausprägung für unterschiedliche Bereiche - zum kulturellen Wissen der Individuen einer Kommunikationsgemeinschaft. Der Hauptteil solchen Wissens leitet sich vom sozialen Wissensvorrat einer Gesellschaft $a b$, in die das Individuum hineingeboren und in der es aufwachsen wird.

Für die kommunikativen Aufgaben, die von diesen Gattungen erfüllt werden, können unterschiedliche intra-nationale und internationale kulturelle Gruppen unterschiedliche Lösungen finden (Günthner/ Luckmann 2002). Entsprechend variiere - so die Forschung - das Repertoire an $\mathrm{G}$ attungen sowie seine Ausprägungen auch von Nationalkultur zu Nationalkultur.

\subsection{Interkulturelle Kommunikationsforschung: Ergebnissichtung}

Diese Hypothese soll anhand der Ergebnisse der interkulturellen Kommunikationsforschung kurz überprüft werden. D abei wird sich im Folgenden auf die drei Ebenen von Gattungen bezogen, die der Forschung nach zu Problemen in der interkulturellen Kommunikation führen können, und zwar erstens auf die Ebene der Binnenstruktur, zweitens auf die Ebene der situativen Struktur und drittens auf die Ebene der Außenstruktur kommunikativer $\mathrm{G}$ attungen. 
D as erste Beispiel zur Binnenstruktur von $G$ attungen, also der Ebene, die die textlichen Merkmale im engeren Sinne umfasst, stammt aus der Forschung des Soziolinguisten John Gumperz (1992). Er argumentiert, dass schon die Handhabung prosodischer Mittel (also z.B. Akzent, Intonation, Sprechtempo) zu kommunikativen Fehlschlägen führen könne. So analysiert Gumperz die Kommunikation zwischen indischen und pakistanischen Cafeteria-Angestellten und britischen Kunden in einem Londoner Flughafen. Dabei wurden die Inderinnen und Pakistani von den britischen $G$ ästen jeweils als unhöflich und unkooperativ wahrgenommen und die Beschwerden häuften sich. Nach den empirischen Studien von Gumperz basierte diese Einschätzung auf dem indischen Intonationsmuster dieser Angestellten. Denn bei Nachfragen produzieren die Briten eine steigende Intonation, während die indischen Sprecher eine fallende Intonation äußerten, was sodann als unhöflich bewertet wurde.

Wesentliche Unterschiede in der Binnenstruktur von Gattungen betreffen auch den lexiko-semantischen Bereich. Zwei Beispiele wurden schon oben genannt: die Verwendung von „Vermittler" und „Kompromiss". Und das unterschiedliche Verständnis des Begriffs „Recht“ im chinesischen und deutschen ist Thema eines der Beiträge in diesem Band. Manche Begriffe sind kaum übersetzbar, wie z.B. das viel zitierte deutsche Wort „Gemütlichkeit". Universale Konzepte wie Heimat, Familie oder Arbeit sind zwar übersetzbar, werden aber der Forschung nach in den jeweiligen Sprachkulturen mit unterschiedlichen Konnotationen und Assoziationen belegt (vgl. Heringer 2004: 174; Kühn 2006: 56; Müller-Jacquier 1981 und 1994). Entsprechend könne auch ihre Verwendung in interkulturellen Situationen zu mehr oder weniger großen Kommunikationsstörungen führen.

Auch thematische Aspekte zeigen der interkulturellen Kommunikationsforschung gemäß durchaus kulturelle Differenzen. Man denke nur an den ganzen Bereich der Tabuthemenforschung. Tabus in interkulturellen Kontaktsituationen betreffen nicht nur die tabuträchtigen Bereiche Religion, Sexualität, Tod, Krankheit und Körperfunktionen, sondern können in vielen anderen Lebensbereichen festgestellt werden. Kniffka beispielsweise stellt fest, dass sich Themen wie „In der Kneipe“ oder „Bademoden“ als Konversationsthema für den Deutschunterricht in arabischen Ländern auf $\mathrm{G}$ rund der dort bestehenden Tabus sicher nicht eignen würden (Kniffka 1995: 43).

Zur Binnenstruktur von Gattungen gehört auch der Aspekt der Gliederungsmerkmale, ein Bereich, den man in der Forschung intensivst bearbeitet hat. So wurden in diesem Zusammenhang z.B. zahlreiche empirische Untersuchungen $\mathrm{zu}$ wissenschaftlichen $\mathrm{G}$ attungen, und so etwa auch zum wissenschaftlichen Vortrag durchgeführt. D abei stellte sich beispielsweise nach Kotthoff (1989) und Antes (1992) heraus, dass Vorträge anglophon-US-amerikanischer Sprecher im Vergleich zu deutschen deutlich mehr Gliederungssignale (erstens, zweitens, drittens, jetzt, im Folgenden, später), mehr Ankündigungen folgender Arbeitsschritte („,und damit komme ich zum nächsten Aspekt") sowie Zusammenfassungen des bereits G esagten enthielten, insgesamt deutlich hörerorientierter angelegt seien. 
Auf deutsche Hörer wirke diese O rientierung - so jedenfalls die Forschung - langatmig und simpel (Antes 1992), während auf der anderen Seite der Vortragsstil der deutschen Referenten auf häufige Verstehensbarrieren stoße.

Nach dieser Darstellung der Binnenstruktur von Gattungen werden im Folgenden kurz Missverständnisse auf der Ebene der situativen Verwirklichung kommunikativer $\mathrm{G}$ attungen dargestellt, auf der jene Merkmale im Vordergrund stehen, die sich auf die Koordination der kommunikativen Handlungen und ihren situativen Kontext beziehen. Unzählige Forschungen haben sich z.B. mit der Realisierung von sprachlichen Intentionen, d.h. von Sprechakten befasst, anfangs vielfach mit Fragebogenerhebungen und oft kontrastiv. Danach sollen deutsche Studierende Sprechakte wie Beschuldigungen, Beschwerden, Aufforderungen oder Bitten direkter als britische formulieren, so jedenfalls Juliane House (1998). Sie spricht sogar insgesamt von einer stärkeren Beziehungsorientierung der britischen Sprecher. Aufforderungen wiederum würden nach Rathmeyr von russischen Sprechern direkter formuliert als von deutschen (Rathmeyr 1996). Sagt ein deutscher Sprecher etwa „Könntest Du mit bitte helfen?", schwäche er also die Bitte durch Partikel, Fragesatz und Konjunktiv II ab, würde ein russischer Sprecher eher einen Aussagesatz im Indikativ mit der Partikel „bitte“ verwenden, wie „Hilf mir bitte!“. Im Chinesischen erfolgt nach Liang zur Konfliktvermeidung eine permanente $\mathrm{Zu}$ rückdrängung des Ich. Entsprechend würde eine Beschwerde z.B. mit der Äußerung realisiert werden: „Wie ich von allen gehört habe, bist du in letzter Zeit oft zu spät gekommen." (Liang 1998: 225). Und nach Muikku-Werner (1992) bevorzugten finnische Moderatoren bei Fragen, Nachfragen und Befehlen gerne elliptische Formen („Ja, oder Nein, Kristina Halkola“, statt „Antworten Sie doch bitte mit ja oder nein, Kristina Halkola“). Die finnischen Sprecher, so die Schlussfolgerung, gingen eher geizig mit Worten um.

Besonders auffällig ist, dass gerade in diesen Forschungen zahlreiche Nationalstereotype linear fortgeschrieben werden, etwa zum höflichen Briten, zum derben Russen, zum wortkargen Finnen oder zum höflichen Chinesen.

Aber bevor zur generellen Kritik an der Forschung übergegangen wird, soll an dieser Stelle noch auf einen letzten Aspekt der interkulturellen Kommunikationsforschung eingegangen werden, der auch intensiv bearbeitet wurde: das Rückmeldeverhalten von Sprechern. Wie stark dabei z.B. unterbliebene Rückmeldungen wirken können, haben Erickson/ Shultz (1982) in einer der ersten Studien zu diesem Aspekte der Kommunikation nachzuweisen versucht. Die Autoren beobachteten „black and white students“ in Beratungssitzungen an amerikanischen Hochschulen. Dabei haben die sogenannten bladk students deutlich weniger an relevanten Stellen rückgemeldet, z.B. keinen Blickkontakt gesucht, nicht genickt, nicht mit Partikeln wie (yeah) aktive Zuhörerschaft signalisiert usw.. The „white counselor" hätte sodann ihre Äußerungen wiederholt, paraphrasiert oder Hypererklärungen formuliert. Letztendlich seien sodann die bladk students von dem white counœeller nicht positiv bewertet und nicht für ein Hochschulstudium empfohlen worden. Ähnliche Studien existieren zum Rückmeldeverhalten japanischer und chinesischer 
Sprecher, wobei man feststellte, dass erstere im Verhältnis zu deutschen äußerst häufig und letztere äußerst selten verbal oder nonverbal zurückmelden würden.

Zudem wird auch die Außenstruktur kommunikativer G attungen für Missverständnisse verantwortlich gemacht (Helmolt 1997), also z.B. die kommunikative Situation, in der etablierte Gattungen jeweils verwendet oder eben vermieden werden. Insgesamt hat die Forschung herausgearbeitet, dass es in interkulturellen Interaktionen auf allen Ebenen der kommunikativen Gattungen und in den meisten Teilbereichen aufgrund kultureller Unterschiede zu Kommunikationsstörungen kommen kann.

\subsection{Interkulturelle Kommunikationsforschung: Z wischenfazit}

Im Folgenden sollen diese Forschungsergebnisse noch einmmal kritisch hinterfragt werden, und zwar

erstens in Bezug auf das verwendete $\mathrm{G}$ attungskonzept, zweitens in Bezug auf die verwendeten Ansätze und Methoden, drittens in Bezug auf die Fokussierung auf Missverständnisse und viertens in Bezug auf die zugrunde liegenden Kulturkonzepte.

Zuerst einmal soll im Folgenden das Gattungskonzept näher erläutert werden. Innerhalb einer Sprachgemeinschaft und innerhalb von Nationalkulturen muss auch von einer inneren Mehrsprachigkeit von Nationalkulturen ausgegangen werden. Entsprechend unterscheiden sich je nach Akteursgruppen die kommunikativen Gattungen und ihre Realisierungen. So kann sich z.B. ein Vortrag eines deutschen Referenten (vgl. Kotthoff 1989) an einer Hochschule, auf einer wissenschaftlichen Tagung oder in beruflichen Zusammenhängen deutlich unterscheiden. D .h., dass eine Aussage - wie die von Günthner/ Luckmann, dass sich Gattungen von Nationalkultur zu Nationalkultur (hier D eutschland - USA) unterscheiden - so undifferenziert nicht stehen gelassen werden kann. Hier müssen bei der Analyse jeweils die entsprechenden sozialen Akteure differenziert in den Blick genommen werden.

Kommunikative $G$ attungen von spezifischen Akteuren bilden zudem nur einen Rahmen und sind einem starken Wandel unterworfen. Auf der anderen Seite ist aber auch zu bedenken, dass G esellschaften normative Setzungen vornehmen, wie etwa mit curricularen Vorschriften, die z.B. die Interaktion im Rahmen der Gattung „Unterrichtsdiskurs" stark prägen können und entsprechend wirkungsmächtig sind. Kommunikative Gattungen sind entsprechend auch sedimentiertes kulturelles Wissen.

Was die Ansätze und Methoden betrifft, so lassen sich bei den einzelnen Untersuchungen unterschiedliche Kritikpunkte aufführen. Genannt seien hier als Punkte kleine Textkorpora, Durchführung der Erhebungen nur mit Fragebogen oder Interviews, keine Untersuchung konkreter interkultureller G espräche, lediglich D urchführung kontrastiver und keiner interkulturellen Studien, kein Einbezug 
des Ko- und Kontextes von sprachlichen Formen, kein triangulärer Zugriff mit mehrenen Methoden u.a.

Grundlegender stellt sich die Kritik in Bezug auf die Konzentration auf Missverständnisse und D ifferenzen in diesen Studien dar. D ie meisten der oben genannten interkulturellen Studien gehen von der Hypothese des Aufeinandertreffens von kulturellen Entitäten mit kulturspezifischen unterschiedlichen Kommunikationskonventionen in interkulturellen Interaktionen aus, die dann unweigerlich zu Missverständnissen in der Kommunikation führen müssen.

Mittlerweile ist diese Sicht bei einigen Forschern der Erkenntnis gewichen, dass auch die interkulturelle Interaktion von G emeinsamkeiten geprägt ist, zum einen von Universalien, da sonst Kommunikation über Sprachgrenzen hinweg nicht möglich wäre, zum anderen von Homogenisierungen auf Grund von G lobalisierungsprozessen. Man denke hier nur an die Anglifizierung der deutschen Wissenschaftskommunikation.

D es Weiteren wird in der Forschung teilweise stärker betont, dass a) kulturelle Unterschiede in der Interaktion oft normalisiert werden (z.B. unterschiedliche Telefongesprächseröffnungen im Dänischen und D eutschen; Rasmussen 2000) oder b) dass bei Unterschieden spezifische interaktive (nicht interkulturelle) Kompetenzen automatisch Verwendung finden, mit denen Missverständnisse vermieden werden (Asmuß 2002).

Noch grundlegender fällt die Kritik in Bezug auf den in den Studien verwendeten K ulturbegriff aus. Die meisten der oben dargestellten Studien gehen von einem homogenen Kulturbegriff aus, etwa, wenn in der Arbeit von G umperz das Verhalten DER Briten dem DER Inder und DER Pakistani gegenübergestellt wird. D och im Zeitalter der Globalisierung stellen wir einen drastisch beschleunigten Prozess kultureller Hybridisierung fest. Er resultiert sowohl aus der extremen Binnendifferenzierung immer komplexer werdender moderner Gesellschaften als auch aus deren stetig sich verzweigenden externen globalen Vernetzungen. Und dieser Prozess dauert an.

In D eutschland z.B. sind von den ehemaligen Zuwanderern eine Million mittlerweile eingebürgert. Es leben dort Zuwanderer in der ersten, zweiten und dritten Generation. Was also umfasst der Begriff D eutschland/ D eutscher, wenn man ihn in oben dargestellten Studien als Ausgangspunkt von Untersuchungen zur deutschtürkischen Interaktion wählt? Und in wieweit kann das Interaktionsverhalten der wie auch immer definierten „D eutschen“ „typisch deutsch" sein, wenn es doch deutlich durch Globalisierungsphänomene geprägt wird: wie z.B. besonders durch die Anglifizierung in der Werbe-, Wissenschafts- oder Wirtschaftskommunikation.

Schlussfolgerungen aus diesen ersten Kritikpunkten wären also insofern zu ziehen, als dass man in einer interkulturellen Interaktionsforschung

a) Typen von sozialen Akteuren für die Realisierung kommunikativer $G$ attungen erarbeitet und diese auch jeweils nur als Analysegrundlage wählt (also nicht den deutschen Vortrag untersucht) und dabei immer von einer inneren Mehrsprachig- 
keit von Kulturen ausgeht, die auch komplexe Formen wie Gespräche und Texte betrifft;

b) sich spezifischer Methoden und Ansätze bedient, z.B. konkrete interkulturelle Interaktionen untersucht und diese möglichst auch triangulär, mit vielfältigen $\mathrm{Me}$ thoden wie teilnehmende Beobachtung, Videoaufzeichnung und Interviews, erforscht;

c) die Fokussierung auf Missverständnisse relativiert und

d) den Studien keinen homogenen Kulturbegriff zugrundelegen und damit auch das Forschungsdesign verändern muss.

D rei weitere zentrale Kritikpunkte, die mit obigen Punkten in engem Zusammenhang stehen, sollen hinzugefügt werden, um sodann in den folgenden Kapiteln noch einmal näher auf diese einzugehen.

Erstens: Vereinzelt setzt sich in der interkulturellen Kommunikationsforschung die Meinung durch, dass Kultur auch (!) als ein Konstrukt angesehen werden muss, das erst in der Interaktion geschaffen wird, und das nicht wesenhaft einem $\mathrm{G}$ egenstand innewohnt oder objektiv vorhanden ist. (Näheres siehe Kapitel 3.1.)

Zweitens: Immer häufiger wird im Zusammenhang mit dem verwendeten Kulturbegriff - wenn auch nicht innerhalb der linguistischen Forschung, sondern eher der Soziologie - die grundlegende Kritik geäußert, dass viele kulturvergleichende und interkulturelle Studien auf Grund ihres Forschungsdesigns einer Kulturalisierung von Interaktionsverhalten Vorschub leisten. (Näheres siehe Kapitel 3.2.)

D rittens: Entgegen der in obigen Arbeiten zu Missverständnissen noch immer vorherrschenden Vorstellung, dass die interkulturelle Interaktion nur eine Reproduktion der sprachlichen Konventionen darstellt, die die Interaktanten in der Eigenkultur erworben hätten, wird neuerdings auch darauf abgehoben, dass diese einen wechselseitigen Aushandlungsprozess darstelle, bei dem neue Interaktionsformen geschaffen würden: eine Interkultur. (Näheres siehe Kapitel 3.3.)

\section{Interkulturelle Interaktion als Prozess}

\subsection{Der Konstruktionsprozess}

D er Konstruktionscharakter von interkultureller Interaktion soll im Folgenden an einem Beispiel verdeutlicht werden. Frau Bao und Herr Guo, beide Staatsbürger der Volksrepublik China, leben derzeit in der VR China, und haben Gäste (Kurt und Uli) aus Deutschland zum Essen eingeladen. Folgende Gesprächsphase hat sich entwickelt (nach Günthner/ Luckmann 2002: 217f.):

Bao: $\quad$ Essen Sie.

Kurt: $\quad$ Nein, danke. Ich bin schon VÖLLIG SATT. 
Bao Ja, nehmen Sie.

Guo: $\quad$ Du musst nicht IMMER SAGEN.

Kurt/ Uli: Hihihi.

Das nicht notwendig bei den D eutschen. Ja?

Bao:

Hihihi.

Uli: $\quad$ Nein. VIELEN D ank. Wir haben echt (-) sind ECHT SATT. Aber s hat ganz TO LL GESCHMECKT.

Kurt: WIRKLICH.

Guo: Die DEUTSCHEN soll man nicht so drängen. Sie nehmen, wann sie wollen. Ja, mach mal keine Sorge. (...) Die Deutschen sind nicht so sehr bescheiden. Hahaha. So ist das.

In diesem G esprächsausschnitt bittet Frau Bao die deutschen $\mathrm{G}$ äste zwei Mal, sich etwas von den Speisen zu nehmen. Ihr Mann, der als Professor ein Jahr in Deutschland gearbeitet hat, interpretiert das Verhalten seiner Frau im deutschen Kontext als aufdringlich und vermittelt seiner Frau, dass man „die Deutschen“ nicht so zum Essen drängen solle, dies sei nicht notwendig. Und weiter: „Die D eutschen ja sind so nicht so sehr ja bescheiden."

Herr Guo führt in diesem Gespräch eine soziale Kategorisierung durch, er ordnet die Gäste einer spezifischen Kultur zu („die Deutschen“) und schreibt diesen Mitgliedern gleichzeitig spezifische Eigenschaften und Verhaltensweisen zu („nicht bescheiden“, „keine mehrmaligen Aufforderungen“) (Hausendorf 2007: 403). D amit nutzt er zwei zentrale Verfahren der "membership categorization“; wie es in der amerikanischen Konversationsanalyse heißt, der Mitgliedschaftskategorisierung: das Zuordnen und Zuschreiben, d.h. man stellt die Zugehörigkeit („,deutsch“) dar und drückt verschiedene Verhaltensweisen und Eigenschaften aus („nicht bescheiden“), die mit diesen Kategorien verbunden sind. Als drittes Element der Mitgliedschaftskategorisierung kommt die Bewertung hinzu, das D arstellen von Einstellungen. Dies, so könnte man vermuten, ist in diesem Beispiel implizit als neutral gegeben, durch die Verwendung der Kategorie „nicht bescheiden": Diese soziale Kategorisierung kann in der interkulturellen Interaktion ein lokales und geradezu flüchtiges Phänomen sein (wenn man z.B. kurz erstaunt ist und die Stim wegen eines Dialekts der G esprächspartners runzelt) oder es kann ein abendfüllendes Programm darstellen, z.B. eine Talkshow zum Thema „Türkische Machos". D abei gestalten sich die sprachlichen Mittel des Zuordnens ganz unterschiedlich.

Man findet etwa personale Formen („hier bei uns“), generische Referenz („der ausländische Unternehmer"), Adversativkonjunktoren („,bei ihnen ist das geläufig, aber bei uns nicht"), das Lexem fremd („also ich komme mir hier völlig fremd vor"), Herkunftsprädikate („also ich bin nicht aus der Türkei“) oder Gattungsprädikate („Sind sie D eutscher?"). Über dieses explizite Zuordnen hinaus existieren auch sehr implizite Formen (mit Partikeln etc.) der Mitgliedschaftskategorisierung, wenn z.B. über explizite Fremdzuschreibungen implizite Selbstzuschreibungen er- 
folgen, wie etwa die eines Westdeutschen über Ostdeutsche aus dem Textkorpus Hausendorfs (2002) (Anfang der 90er Jahre) „gerade diese völlige Verbocktheit und Kommunikationsgestörtheit der O ssis".

Nach diesem Ansatz der interkulturellen Interaktionsforschung wird der Blick auf die kommunikativen G rundlagen der Selbst- und Fremddarstellung und des damit einhergehenden Zuordnens von Personen zu sozialen Gruppen gelenkt, und damit auch auf die Prozesse der Herstellung, Aufrechterhaltung und Auflösung von Wir-G ruppen, von kollektiver Identität, von Ab- und Ausgrenzung, und natürlich von Diskriminierungen von $\mathrm{G}$ ruppen:

So etwa im folgenden Beispiel, dass ebenfalls dem Korpus von Hausendorf (2002) entnommen ist, in dem ein D eutscher über seine Erfahrungen in einem Fußballclub berichtet, in dem afrikanische Sportler spielten: „die warn ja, das is in Afrika so üblich, die motzen sich laufend an. Ja, und ich war einer der Nichtafrikaner. Auf mir ham se dann vor allen Dingen rumgehackt, wenn ich n Fehler mache. (... ) Und dann war ich mal bei einem Turnier da, da sollten nur afrikanische Mannschaften spielen, Und äh es folgte also eigentlich sollte das Turnier um zwölf Uhr losgehn, und eh um siebzehn Uhr fing es dann an. Und dann waren die auch nur am Diskutieren“. In diesem Beispiel finden sich zuhauf Zuordnungen, $\mathrm{Zu}$ schreibungen und Bewertungen.

Insgesamt vertreten Wissenschaftler dieser Richtung die Meinung, dass Kultur ein kommunikatives Konstrukt darstelle (so z.B. Hausendorf 2002), das in einer Reihe stehe mit Konstrukten wie „Nation“ oder „Ethnie“ (ähnlich auch Wimmer 2007).

Aus diesem Ansatz heraus sollten zwei grundlegende Schlussfolgerungen gezogen werden. Zum einen sollte die Forschung diese Mitgliedschaftskategorisierungen immer im Blick haben. Mit ihnen werden Differenzen konstruiert, die in der Realität nicht vorhanden sind - oder besser, möglicherweise nicht vorhanden sind. Diese Konstrukte sind aber wirkungsmächtig und beeinflussen das Handeln, etwa durch die Erwartungshaltungen der Interaktanten, die in die Gesprächssituation eingebracht werden. Ein Beispiel dafür bildet eine Gruppe chinesischer Studierenden, denen medial vermittelt wurde, dass in D eutschland sehr direkt kommuniziert werde. Entsprechend agierten sie bei Anfragen und Bitten in Studienzusammenhängen sehr direkt und stießen dabei auf großes Befremden.

D ie zweite Schlussfolgerung aus der Tatsache, dass Kultur auch ein kommunikatives Konstrukt sei, sollte darin bestehen, dass in der Forschung nicht von Setzungen ausgegangen wird, also „Kultur" , „Nation“ oder Ethnie“ nicht als Ausgangspunkt der Untersuchungen gewählt werden. In Bezug auf Ethnien formuliert Wimmer (2007) in diesem Zusammenhang: "The ethnic group formation perspective calls for non ethnic units of observation which make it possible to see whether and which ethnic groups and boundaries emerge, are subsequently transformed or dissolve - rather than to assume their existence, relevance and continuity by binding the observational apparatus to such groups and communities." (Wimmer 2007: 26) 
Ausgangspunkt der Analysen sollten entsprechend nach Wimmer Interaktionsräume und Institutionen sein, so etwa im Migrationszusammenhang Stadtteile oder Schulen oder in internationalen Kontexten Begegnungsräume wie Hochschulen, Unternehmen, Kulturinstitutionen oder Medien in verschiedenen L ändern.

Werden also zum Beispiel Projekte im Migrationskontext geplant, so sollte als Untersuchungsgegenstand nicht „D ie deutsch-türkische oder deutsch-russische Interaktion“, sondern z.B. die Institution "Schule" als Untersuchungsfeld gewählt werden. Sodann typisiert man diesen Bereich der Institution Schule (Grundschule, Berufschule, ländliche $\mathrm{G}$ rundschule, städtische $\mathrm{G}$ rundschule etc.) und versucht, an einem Typus „Schule“ Besonderheiten herauszuarbeiten, die möglicherweise generalisierbar sind.

D abei werden die Spezifika der Interaktion von autochtonen und allochtonen Mitgliedern der Schülerschaft mit den Lehrenden erarbeitet, dies aber immer unter Einbezug des Kontextes des gewählten Typs der Institution Schule. Möglicherweise, aber nicht unbedingt, stellen sich sodann Ergebnisse ein, die darauf verweisen, dass Interaktionsspezifika bestimmter Zuwanderergruppen existieren, ohne dass dies jedoch schon im Forschungsdesign vorausgesetzt wird. Mit einem derartigen Ansatz wird einem „methodologischen Nationalismus" oder einer „methodologischen Ethnisierung" in interkulturellen und kulturvergleichenden Studien entgegengewirkt, vor dem insbesondere Wimmer/ G lick Schiller (2002: 579) warnen. D amit zusammenhängend ist ein weiterer Aspekt bei der Untersuchung wichtig.

\subsection{Multifaktorielle Einflüsse auf interkulturelle Interaktionen}

Geht man noch einmal auf das oben angeführte Beispiel der deutsch-chinesischen Interaktion zurück, so lässt sich festhalten, dass Herr Guo - so jedenfalls lässt es sich aus seiner Selbstdarstellung schließen - seine Gesprächskonventionen auf Grund seiner biographischen Erfahrungen für die interkulturelle Interaktion mit den deutschen Gästen modifiziert, indem er die Aufforderung zum Essen nicht mehr mehrfach wiederholt. (Wie er intrakulturell mit chinesischen Freunden handelt, ist eine andere Frage).

Frau Bao dagegen durchläuft in dieser Interaktion einen Lernprozess und wird möglicherweise beim nächsten Besuch deutscher $\mathrm{G}$ äste anders handeln.

Diese beiden Personen mit chinesischer Staatsbürgerschaft verhalten sich aus individuellen biographischen Erfahrungen in der interkulturellen Situation unterschiedlich. Eine Forschung, die sich darauf konzentriert, Unterschiede in DER deutschen und DER chinesischen Interaktionskonventionen zu suchen, würde in dieser Situation eine Bestätigung ihrer Vorannahmen finden. So benutzen denn auch Günthner/ Luckmann (2002) dieses Beispiel, um zu zeigen, wie unterschiedliche Wissensbestände von Kulturen (Konventionen beim Anbieten von Speisen) zu unterschiedlichem interaktiven Verhalten und zu Missverständnissen führen könnten. 
D eutlicher wird aber an diesem Beispiel eher, wie unterschiedliche bio-graphische Hintergründe und Erfahrungen der beteiligten Interaktanten aus der VR China die Interaktion bestimmen. Globalisierung und insbesondere Mobilität haben hier zu Verhaltensveränderungen sowie Differenzierungen des Verhaltens der chinesischen Interaktanten ( $\mathrm{G}$ ao anders als Bao) geführt. Dies stellt damit ein Indiz dafür dar, dass man nicht allein homogenisierende kulturalistische Begründungen für sprachliches Verhalten suchen darf.

Gerade, um dem Vorwurf eines „methodischen Kulturalismus“ (Nohl 2007: 399) abzuwehren, schränken Forscher anderer Disziplinen (z.B. Sozialwissenschaftler) daher die Reichweite ihrer empirischen Ergebnisse ein, indem sie die Relevanz anderer sozialer Aggregate, etwa von individuellen Eigentümlichkeiten, sozialer Herkunft oder so genannten transnationalen C ommunities betonen.

D iese theoretische Relativierung von Kultur und Nation als Untersuchungseinheit kann dazu führen, auf der Flucht vor der „Charybdis des methodologischen Nationalismus oder Kulturalismus" zur "Scylla des methodologischen Fluidismus abzudriften", so Wimmer/ Glick Schiller (2002: 600) wie auch Nohl (2007). Eine Lösung dieses Problems besteht darin, dass bei der Untersuchung interkultureller Interaktion immer deutlich bleibt, dass Kultur nur eines unter sehr vielen sozialen Aggregaten darstellt.

Dies bedeutet, dass vergleichende und interkulturelle Analysen immer auf mehreren Ebenen ablaufen müssen, in der Sozialforschung als Mehrebenenanalyse bekannt (Nohl 2007: 399).

Aus der Soziolinguistik wäre hier im Übrigen das Konzept der Varietätenlinguistik zu integrieren. Allgemein ausgedrückt werden in einer solchen Mehrebenenanalyse die zu betrachtenden sozialen Aggregate zusätzlich jeweils einzeln einer Analyse unterzogen.

Betrachtet man noch einmal das obige Beispiel der interkulturellen Interaktion von autochtonen und allochtonen Schülern sowie Lehrenden in schulischen $\mathrm{Zu}$ sammenhängen, so lässt sich folgendes Verfahren vorschlagen. Als Ausgangspunkt wird, um kulturalistische Setzungen zu vermeiden, ein Typus der Institution Schule gewählt (Realschule Kleinstadt). Eine Analyse des Interaktionsverhaltens aller Beteiligten wird dieses nun differenziert in Bezug auf ihre Zugehörigkeiten zu unterschiedlichen sozialen Aggregaten, etwa biographischen Eigentümlichkeiten, Schicht, Bildung, Stadt/ Land (Areal), Gender, Generation und eben der Zugehörigkeit zu Ethnie, Nation oder Kultur untersuchen.

Ein aus schulischer Sicht problematisches Interaktionsverhalten - geringe Initiative oder geringe Reaktion, stringentes Abgrenzungsverhalten, Einsatz begrenzter Sprechakttypen - (z.B. keine Fragen oder kein Widerspruch) eines Schülers muss dann im Hinblick auf seine Beziehung zu diesen einzelnen sozialen Aggregaten geklärt werden.

Einem methodischen Kulturalismus wurden in den oben dargestellten Studien zur interkulturellen Kommunikation auch deshalb Vorschub geleistet, weil die situativen Faktoren der Interaktion, die kommunikativ-pragmatischen Einflussfak- 
toren, bei der Interpretation von Missverständnissen in der interkulturellen Interaktion häufig unzulässig vernachlässigt wurden. D enn nicht nur die Interaktanten, sondern auch die Forscher tendieren dazu, die situativen Ursachen für Missverständnisse in interkulturellen Interaktionen zugunsten von kulturellen Aspekten zu ignorieren (Busch 2003: 87; vgl. Tzanne 2000).

Entsprechend müssen neben den oben aufgeführten sozialen Bezugspunkten auch kommunikativ-pragmatische Faktoren bei der Interpretation eines Interaktionsverhaltens mit in Betracht gezogen werden: so z.B. das soziale Verhältnis der Gesprächspartner (und seine Wahmehmung, etwa Lehrer-Schülerverhältnis), der Grad der Öffentlichkeit (privat oder öffentlich), ob face-to-face-Kommunikation stattfindet oder nicht, der Bekanntheitsgrad der $\mathrm{G}$ esprächspartner (von vertraut bis unbekannt), die Handlungsdimension des $\mathrm{G}$ esprächs (direktiv, narrativ, diskursiv (alltäglich, wissenschaftlich), O rt, Zeit, Raum, eben den gesamten Kontext der Äußerung, die Summe der Faktoren, welche die Verhaltensreaktion beeinflussen.

D iese kommunikative Situation wird auch durch vier weitere wichtige D imensionen mit geprägt, die in die Situation der Interaktion mit eingebracht werden (Auernheimer 2006, 14): die Erwartungshaltungen der Interaktanten (durch medienvermittelte Fremdbilder (direkter Chinese in D eutschland) (subjektive D imensionen), Kollektiverfahrungen mit der Kontaktgruppe (z.B. D eutsche und Polen; Europäer und Afrikaner) und Machtasymmetrien (bei Beratungsgesprächen mit Zuwanderern). G erade Machtasymmetrien z.B. führen dazu, dass Missverständnisse nicht - wie etwa bei interkulturellen Alltagsgesprächen - mit metakommunikativen Reparaturmechanismen ohne Folgen behoben bzw. normalisiert werden, sondern dass Kommunikationsstörungen eher den Zuwanderern angelastet werden und zu Diskriminierungen führen (vgl. Auemheimer 2006: 14 und 151).

D arüber hinaus prägt natürlich - wie oben schon angedeutet - die kommunikative $\mathrm{G}$ attung, der Rahmen, in dem sich die Interaktanten bewegen, die Interaktion.

Mit dieser Mehrebenenanalyse und dem Einbezug multifaktorieller Begründungszusammenhänge sind kulturelle Faktoren nicht Ausgangspunkt einer Analyse interkultureller Interaktion, sondern sie können höchstens - müssen aber nicht - das Ergebnis eines differenzierten Analyseprozesses sein. Entsprechend wird auch einem methodischen Kulturalismus entgegengewirkt.

\subsection{Der Aushandlungsprozess}

Ein dritter Aspekt ist an dem oben aufgeführten deutsch-chinesischen Gespräch wichtig. Die Interaktionspartner handeln hier gemeinsam ihr interaktives Vorgehen aus. Herr Guo bittet auf die Reaktion der D eutschen hin seine Frau, mit dem Drängen aufzuhören, Frau Bao reagiert auf ihren Mann und unterlässt das Drängen, und die deutschen Gäste loben nach dieser Aushandlung des weiteren Vorgehens Frau Baos Essen, als nachträgliche positive Beziehungsarbeit. 
Die Interaktionspartner haben damit wechselseitig aufeinander reagiert, das G espräch dynamisch gestaltet, und Formen gefunden, die - zumindest nach Wahrnehmung der Teilnehmer - weder in der Eigenkultur noch in der Fremdkultur relevant sind.

Insgesamt richten mittlerweile ausgewählte Forscher ihr Augenmerk mehr und mehr auf diese Interaktionsdynamik interkultureller Prozesse (Koole/ ten Thije 1994a und b; Bührig/ ten Thije 2006; auch Rehbein 2006; Rehbein 2007). Diese werden nicht mehr - wie früher - als ein „Aufeinandertreffen verschiedener Kultur- und Kommunikationsformen, sondern als situationsspezifisches Aushandeln verstanden, in dem die Kommunikationspartner signifikant anders reagieren als in Kommunikationssituationen mit Vertretern aus der eigenen Kultur und entsprechend $\mathrm{zu}$ neuen hybriden Formen sprachlichen Handelns kommen. In der interkulturellen Forschung ist hierfür der Begriff „Interkultur" geprägt worden, der eine kommunikative „Zwischenkultur" bezeichnen soll, die durch den Kulturkontakt konstruiert wird." (Müller-Jacquier 1999: 37). Dabei entstehen Diskursformen, die in ihrer Eigenart nicht mehr rückführbar auf "typisch deutsche" oder "typisch indische" Verhaltensweisen sind (Ten Thije 2002).

Blickt man zurück auf die oben dargestellte Forschung zu interkulturellen Missverständnissen, so wird dieser Prozesshaftigkeit und diesem Aushandlungsprozess von Interaktanten in der interkulturellen Interaktion nur wenig Aufmerksamkeit geschenkt.

Obwohl diese Sichtweise auf die interkulturelle Interaktion eine wichtige Sichtweise darstellt, muss aber auch kritisch eingewendet werden, dass dieser geschilderte Aushandlungsprozess von neuen Interaktionsstrukturen von den Interaktanten auch gewollt sein muss. D ie Schaffung einer Interkultur erfordert zugleich das Einverständnis und die Kooperationsbereitschaft aller an der Situation Beteiligten. (Busch 2003: 28) Eine derartige Kompetenz zur Schaffung einer Interkultur (als Neuem) kann daher nicht bei allen Menschen und in allen Situationen vorausgesetzt werden. Sie muss gewollt und aufgrund von Machtverhältnissen auch möglich sein. Ten Thije (2002: 67) differenziert denn auch 2002 mehrere Möglichkeiten der Prägung des Sprach- und Kulturkontakts. Dabei bezieht sich dieses Sprach- und Kulturkontakt-Modell wiederum sehr stark auf homogene kulturelle Entitäten.

Mögliche Folgen des Sprach- und Kulturkontakts nach Ten Thije (2002):

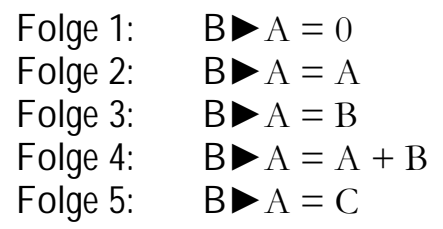

Im ersten Fall stoßen nach Ten Thije verschiedene Problemlösungspotentiale aufeinander, wobei sich Störungen und Missverständnisse ergeben, unter dieser Perspektive haben die bisherigen Forschungen interkulturelle Interaktion vor allem 
betrachtet. Im zweiten Fall adaptieren die Interaktanten der einen Kultur die Interaktionskonventionen der anderen Kultur (etwa Zuwanderer, die sich assimilieren), im dritten geschieht es umgekehrt (etwa deutsche Unternehmer, die sich aus Erfolgsinteresse an chinesische Konventionen der G esprächsführung anpassen wollen), im vierten nutzen die Interaktanten abwechselnd verschiedene Potentiale und im fünften entwickeln sich diskursive Strukturen, die nicht auf die beiden in Kontakt stehenden Kulturen zurückzuführen sind. Ten Thije geht damit davon aus, dass die Interkultur nur eine der Folgen des Sprach- und Kulturkontakts darstellt (Ten Thije 2002: 67).

D ieses Gesamt-Modell des Kulturkontakts unterliegt, so wie es Ten Thije darstellt, wiederum der Kritik, dass es trotz des Aspekts hybrider Interkultur (Folge 5) Kulturen als homogene Entitäten fasst, die in unterschiedlicher Form aufeinander reagieren. Man könnte das Modell weiterentwickeln, indem man bestimme Aspekte einbringt. So könnte man den transkulturellen Charakter von Kulturen mit gestrichelten Kreisen, die innere Differenzierung von Kulturen mit hochgestellten Ziffern darstellen Dann könnte ein problematisches Aufeinandertreffen von B1 und A 2 eben nicht kulturelle, sondern z.B. schichtspezifische $\mathrm{G}$ ründe besitzen, eine Kommunikationsstörung zwischen A1 und B1 wiederum möglicherweise kulturelle Gründe haben. Aber das Aufeinandertreffen könnte eben auch zu Formen einer Interkultur führen.

\subsection{Interkultur als kreatives Potential}

D amit kann zumindest argumentiert werden, dass in interkulturellen Interaktionen nicht nur Missverständnisse aufeinander stoßen, sondern auch interkulturelle Interaktionsräume dazu genutzt werden, dass mögliche in die Situation eingebrachte Konventionen (welchen sozialen Aggregaten sie auch immer zuzuordnen sind) adaptiert und verändert werden, um einen Problemlösungsprozess zu bewirken. Schon Koole/ Ten Thije und andere zeigen damit in ihren Studien, wie Interaktionspartner in interkulturellen Kontaktsituationen das situative Potential kreativ nutzen können, um die „Chance“ des interkulturellen Dialogs erfolgreich zu meistern.

In dieser Konzeption wird Heterogenität als Chance begriffen, als Chance zur Reflektion, Chance des Austauschs und der interkulturellen Verständigung. Heterogenität wird damit nicht nur als Behinderung der Kommunikation, sondern auch als Bereicherung verstanden, mit der erstarrte Formen und Konventionen von Interaktion aufgebrochen werden und zu neuen Formen finden.

„D abei verlassen die Interaktanten den eigenen Horizont, um den dialogischen Kontakt mit der möglichen Alterität anderer Kulturen oder möglicher anderer kultureller Positionierungen zu suchen, um dadurch auch die eigene Positionalität aus einer Außenperspektive wahrnehmen zu können." (Antor 2006: 33). Die Pluralität von Kulturen und somit ihre Andersartigkeit ermöglicht einen befruchtenden interkulturellen Dialog. 


\section{Interkulturelle Interaktion: Widersprüche - Brechungen}

Es bleiben, trotz aller Weiterführungen der interkulturellen Kommunikationsforschung, und bei allen Versuchen, die differenzierte Problematik und Komplexität interkultureller Interaktion einzufangen, weiterhin zahlreiche Fragen offen. Interkulturelle Interaktion ist auch ein Phänomen, das Widersprüche und Brechungen in sich birgt: die G leichzeitigkeit des Ungleichzeitigen.

\subsection{Konstruktivismus - O bjektivismus}

Konzepte wie „Nation“ oder „Ethnie“, das hat die Forschung gezeigt, sind auch Konstruktionen. Aber selbst ein Konstruktivist wie der Soziologe Wimmer verweist darauf, dass Forschung, wenn sie so angelegt ist, wie oben geschildert, sehr wohl zu Ergebnissen kommen kann, die reale differenzierte ethnische und nationale Besonderheiten aufzeigen kann. So warnt auch Wimmer davor, in der Flucht vor der „Charybdis des methodologischen Nationalismus" zur "Scylla des methodologischen Fluidismus abzudriften“ (Wimmer/ G lick Schiller 2002: 600).

\subsection{Interkulturalität - Transkulturalität}

Auf dieser Basis lassen sich auch die Konzepte von Inter- und Transkulturalität weiter denken. Aufgrund des oben schon erwähnten drastisch beschleunigten Prozesses kultureller Hybridisierung spricht man mittlerweile statt von Inter- auch von Transkulturalität. D och mir scheint, ganz im Sinne Antors, dass trotz aller Globalisierungs- und Hybridisierungsprozesse das Konzept der Transkulturalität, der kompletten Auflösung der konzeptuellen Grenzen von Einzelkulturen noch vielfach über den Status Quo, den wir in der Welt antreffen, hinausgeht. Die Hybridisierungsprozesse schreiten zwar in der Tat mit großer G eschwindigkeit voran, aber die Abdrucke monokultureller Formationen sind überall noch sichtbar. Ganz im Gegenteil: Ansätze von Kritikern, die die wachsende Homogenisierung der Welt feststellen, ja sogar anprangern, ignorieren die neue kulturelle Diversität und die kulturellen Partikularismen, die gerade als Reaktion auf globale Homogenisierungstendenzen entstehen.

So sprechen beispielsweise Wimmer und G lick/ Schiller in Bezug auf die Rolle des Nationalstaats: "Not only does it remain true that 95 percent of the people of the world are not migrants but it is also true that, despite global media and rapid flows of information, national identities remain salient in many localities around the world." (Wimmer/ G lick Schiller 2002: 326).

Entsprechend müssen sich interkulturelle Studien immer zwischen den Polen einer uniformierend-globalisierenden Betrachtungsweise und einem partikularistischen Ansatz finden, ohne jedoch einem dieser beiden Pole vollends anheim zu fallen. (Antor 2006: 35). 


\section{$5 \quad$ Interkulturelle Bildung}

Für die interkulturelle Bildung bedeuten diese Zusammenhänge, dass keinesfalls mehr mit einfachen, sei es inter- oder mittlerweile transkulturellen Trainings und Lernprogrammen auf interkulturelle Begegnungen vorbereitet werden kann. Die entsprechenden Konzepte müssen kulturtheoretische Überlegungen integrieren und reflektieren und ein differenziertes Basismodell interkultureller Interaktionen einsetzen.

Im Migrationszusammenhang gilt, dass z.B. in den Schulen nicht alle Probleme auf Kulturzugehörigkeit reduziert werden dürfen. Die soziale Vielfalt und der Bildungshintergrund der Herkunftsfamilien stellen ebenfalls entscheidende Faktoren dar. G leichzeitig gilt aber auch, dass Lehrende in Schulen zu wenig auf die kulturelle Vielfalt in den Klassen vorbereitet sind. Interkulturelles Lernen ist zudem an vielen Schulen noch ein Fremdwort, auch wenn es seit Anfang der 90er Jahre in den Curricula längst verankert ist.

Und zu guter Letzt ist festzustellen, dass bei allen Diskussion die Aufmerksamkeit immer sehr stark auf die Migrationskinder und -jugendlichen in Schulen gelenkt wird, ohne die Mitschüler oder die Lehrenden in den Blick zu nehmen. Eine Interaktionsanalyse, die auch Schlussfolgerungen für die Praxis ziehen will, muss alle Beteiligten im Blick haben. Und muss interkulturelle Interaktion nicht nur als Hindernis, sondern auch als Chance begreifen.

\section{Literaturangaben:}

Antes, Peter (1992): Der wissenschaftliche Vortrag. Englische, französische und deutsche D arstellungsformen im Vergleich. In: Publizistik 37, 3, 322-330.

Antor, Heinz (Hrsg.) (2006): Inter- und T ransk ulturelle Studien. Theoretische G rundlagen und interdisziplinäre Prax is. Heidelberg: Universitätsverlag.

Antor, Heinz (2006): Multikulturalismus, Interkulturalität und Transkulturalität. Perspektiven für interdisziplinäre Forschung und Lehre. In: Antor, Heinz (Hrsg.) (2006): Inter- und Transkulturelle Studien. Theoretische Grundlagen und interdisziplinäre Prax is. Heidelberg: Universitätsverlag, 25-39.

Asmuß, Birte (2002): Struk turelle D issensmark ierungen in interk ultureller Kommu-nik ation. A nalysen deutsch-dänischer V erhandlungen. Tübingen: Niemeyer. (Lingustische Berichte; 452).

Auernheimer, G eorg (2006): E inführung in die Interk ulturelle Pädagogik. 4. Aufl. D armstadt: Wissenschaftliche Buchgesellschaft.

Bührig, Kristin/ ten Thije, Jan D . (Hrsg.) (2006): Beyond misunderstanding, the linguistic reonstruction of intercultural discourse. Amsterdam: Benjamins. 
Busch, Dominic (2003): D er E influss situativer Faktoren in interkulturellen Kontak tsituationen. E mpirisch dargestellt an $\mathrm{G}$ esprächen polnischer und deutscher Studierender. Stuttgart: ibidem.

Casper-Hehne, Hiltraud (2008): Interkulturelle Kommunikation aus sprachwissenschaftlicher Perspektive: Kritische Reflektion der Forschungsansätze und Forschungsergebnisse im deutsch-indischem Zusammenhang. In: CasperHehne, Hiltraud/ Gupte, Nitan (Hrsg.): Communication across boundaries. G öttingen/ Pune. (In Vorbereitung)

Casper-Hehne, Hiltraud (2008): Russisch-deutsche Interaktion in der Schule: Empirische Untersuchungen zu Linguistik und Didaktik interkultureller Unterrichtskommunikation. In: Z ielsprache D eutsch 3. (In Vorbereitung).

Casper-Hehne, Hiltraud (2007): Interkulturelle Wissenschaftskommunikation. Zu Linguistik und Didaktik von Seminarkommunikation an einem deutsch-chinesischen Fallbeispiel. In: Vorstand des Arbeitskreises für interkulturelle Germanistik in China (Hrsg.): D eutsch-Chinesisches Forum interk ultureller Bildung. Band 1: W issenschaft im internationalen Kontex t. München: iudicium, 145-158.

Casper-Hehne, Hiltraud (2006): Interk ulturelle A lltagsk ommunikation zwischen anglophonen US-amerikanischen FremdsprachenlernerInnen und deutschen $\mathrm{M}$ uttersprachlerInnen. $\mathrm{Zu}$ narrativen, disk ursiven und direkten $\mathrm{G}$ esprächen. Tübingen: Niemeyer. (Reihe G ermanistische Linguistik; 265).

Casper-Hehne, Hiltraud (2005): Wissenschaftskommunikation kontrastiv. Zum Stand der Forschung. In: Riemer, Claudia u.a. (Hrsg.): D eutsch als Fremdsprache. Sprachen lehren - Sprachen lernen. Regensburg: Fachverband Deutsch als Fremdsprache. (D okumentationen des $\mathrm{FaDaF}$ ).

Casper-Hehne, Hiltraud (2005): Handlungs- und Beziehungsaspekte in der Wissenschaftskommunikation ausländischer Studierender. Probleme - Perspektiven. In: Casper-Hehne, Hiltraud/ Ehlich, Konrad (Hrsg.): Kommunikation in der W issenschaft. Regensburg: Fachverband D eutsch als Fremdsprache. (Materialien D eutsch als Fremdsprache; 69), 57-73.

Casper-Hehne, Hiltraud (2005): Perspektiven einer kontrastiven Erforschung der Wissenschaftskommunikation: am Beispiel deutscher und anglophoner Transkripte und Gespräche. In: DAAD (Hrsg.): G ermanistentreffen D eutschland G roßbritannien, Irland. 30.09. - 3.10.2004. Dresden. Dokumentation der Tagungsbeiträge, 207-217.

Erickson, Fred/ Shultz, Jeffrey J. (1982): The Counselor as the Gatek eeper: social and cultural organization of communication in counselling interviews. New York/ Philadelphia. Academic Press. 
Goffmann, Erving (1977): Rahmenanalyse. E in V ersuch über die Organisation von A lltagsorganisation. Frankfurt/ M.: Suhrkamp.

Günthner, Susanne/ Luckmann, Thomas (2002): Wissensasymmetrien in interkultureller Kommunikation. In: Kotthoff, Helga (Hrsg.): Kulturen in Kontakt. Tübingen: G ünter Narr. (Literatur und Anthropologie; 14), 213-243.

Gumperz, John J. (1992): D iscourse Strategies. Cambridge: University Press.

Hausendorf, Heiko (2007): Gesprächs-/ Konversationsanalyse. In: Straub, Jürgen/ Weidemann, Arne/ Weidemann, Doris (Hrsg.): H andbuch interk ulturelle Kommunikation und Kompetenz. Stuttgart/ Weimar: J. B. Metzler, 403-415.

Hausendorf, Heiko (2002): Kommunizierte Fremdheit. Zur Konversationsanalyse von Zugehörigkeitsdarstellungen. In: Kotthoff, Helga (Hrsg.): Kulturen in Kontakt. Tübingen: G ünter Narr. (Literatur und Anthropologie; 14), 25-59.

Heringer, Hans-Jürgen (2004): Interk ulturelle Kommunikation. G rundlagen und Konzepte. Tübingen/ Basel: Francke.

Hinnenkamp, Volker (1989): Interaktionale Soziolinguistik und Interk ulturelle Kommunikation: G esprächsmanagement zwischen D eutschen und Türken. Tübingen: Max Niemeyer.

House, Juliane (1998): Kontrastive Pragmatik und interkulturelle Kompetenz im Fremdsprachenunterricht. In: Börner, Werner/ Vogel, Klaus (Hrsg.): Konstrast und Ä quivalenz: Beiträge zu Sprachvergleich und Ü bersetzung. Tübingen: Narr, 62-88.

Kniffka, Hannes (1995): Lückenkontrast. Elemente einer „kulturkontrastiven“ Grammatik Deutsch-Arabisch und Deutsch-Chinesisch. In: Kniffka, Hannes (Hrsg.): E lements of $\mathrm{C}$ ulture-C ontrastive L inguistics. E lemente einer kultur-k ontrastiven L inguistik. Frankfurt/ M.: Peter Lang, 37-62.

Koole, Tom/ten Thije, Jan (1994a): The C onstruction of Intercultural D isourse: Team D iscussions of Educational A dvisers. Amsterdam/Atlanta: Editions Rodopi. (Utrecht Studies in Language and Communication; 2).

Koole, Tom/ten Thije, Jan (1994b): D er interkulturelle Diskurs von Teambesprechungen. Zu einer Pragmatik der Mehrsprachigkeit. In: Brünner, Gisela/ $\mathrm{G}$ raefen, $\mathrm{G}$ abriele (Hrsg.): T ex te und D isk urse. M ethoden und Forschungs-ergebnisse der F unk tionalen Pragmatik. O pladen: Westdeutscher Verlag, 412-434.

Kotthoff, Helga (Hrsg.) (2002): Kultur(en) im G espräch. Tübingen: Günter Narr. (Literatur und Anthropologie; 14).

Kotthoff, H. (1989): So nah und doch so fern. D eutsch-amerikanische pragmatische Unterschiede im universitären Milieu. In: Info D aF 4, 448-459.

Kühn, Peter (2006): Interkulturelle Semantik. Nordhausen: Verlag Traugott Bautz. (Interkulturelle Bibliothek; 38). 
Liang, Yong (2000): Höflichkeit als xenologisches Thema der interkulturellen Kommunikation. In: Wierlacher, Alois (Hrsg.): Kulturthema Kommunikation. Konzepte - Inhalte - F unk tionen. Möhnesee: Residence Verlag, 233-257.

Liang, Yong (1998): Höflichkeit im Chinesischen. Geschichte - Konzepte - H andlungsmuster. München: iudicium.

Luckmann, Thomas (1986): Grundformen der gesellschaftlichen Vermittlung des Wissens: Kommunikative Gattungen. In: Kölner Z eitschrift für Soziologie und Sozialpsychologie, Sonderheft 27, 191-211.

Müller-Jacquier, Bernd (1999): Interkulturelle Kommunikation und Fremdsprachendidaktik. E in Studienbrief zum Fernstudienprojekt „Fremdsprachen im G rundstudium“. Koblenz: Universität Koblenz-Landau.

Müller, Bernd-Diedrich (1994): W ortschatzarbeit und Bedeutungsvermittlung. Tübingen: G unther Narr.

Müller, Bernd-Diedrich (1981): Konfrontative Semantik . Tübingen: G unther Narr.

Muikku-Werner, Pirkko (1992): Sind die Finnen Barbaren? Kontrastive Analyse deutscher und finnischer Abschwächungstechnik. In: Reuter, Ewald (Hrsg.): W ege der E rforschung deutsch-finnischer Kulturunterschiede in der W irtschaftsk ommunikation. Tampere: Tampereen Yliopisto Jäljennepalvelu. (Publikationsreihe des Sprachenzentrums der Universität Tampere; 3/ 1991), 75-100.

Nohl, Arnd-Michael (2007): Komparative Analyse als qualitative Forschungsstrategie. In: Straub, Jürgen/ Weidemann, Arne/ Weidemann, D oris (Hrsg.): $\mathrm{H}$ andbuch interk ulturelle Kommunikation und Kompetenz. Stuttgart/ Weimar: J.B. Metzler, 391-403.

Rasmussen, Gitte (2000): Zur Bedeutung kultureller Unterschiede in interlingualen interk ulturellen $\mathrm{G}$ esprächen. E ine Mikroanalyse deutschsprachiger Interak tionen zwischen Franzosen und $\mathrm{D}$ änen und zwischen $\mathrm{D}$ eutschen und $\mathrm{D}$ änen. München: iudicium Verlag. (Reihe interkulturelle Kommunikation; Bd. 5).

Rathmeyr, Renate (1996): Höflichkeit als kulturspezifisches Konzept. Russisch im Vergleich. In: O hnheiser, Ingeborg (Hrsg.): W echselbeziehungen zwischen slawischen Sprachen, Literaturen und Kulturen in V ergangenheit und G egenwart. (Innsbrucker Beiträge zur Kulturwissenschaft. Slavica Aenipontana; 4), 174-185.

Redder, Angelika/ Rehbein, Jochen (1987): A rbeiten zur interkulturellen Kommunik ation. Bremen. (O snabrücker Beiträge zur Sprachtheorie. O BST; 38).

Rehbein, Jochen (2007): Sprachpragmatische Ansätze. In: Straub, Jürgen/ Weidemann, Arne/ Weidemann, D oris (Hrsg.): H andbuch interk ulturelle Kommunikation und Kompetenz. Stuttgart/ Weimar: J.B. Metzler, 131-144. 
Rehbein, Jochen (2006): The cultural apparatus. Thoughts on the relationship between language, culture and society. In: Bührig, Kristin/ten Thije, Jan D. (Hrsg.) (2006): Beyond misunderstanding, the linguistic reconstruction of intercultural discourse. Amsterdam: Benjamins, 43-96.

Rehbein, Jochen (1994a): Widerstreit. Semiprofessionelle Rede in der interkulturellen Arzt-Patienten-Kommunikation. In: Klein, Wolfgang/ Dittmar, Norbert: Interk ulturelle Kommunikation. Göttingen. (Zeitschrift für Literaturwissenschaft und Linguistik; H. 93), 123-151.

Rehbein, Jochen (1994b): Rejective proposals: Semi-professional speech and clients' varieties in intercultural doctor-patient communication. In: Multilingua. Journal of C ross-aultural and Interlanguage C ommunication, 13, 1/ 2, 83-130.

Rehbein, Jochen (1986): Institutioneller Ablauf und interkulturelle Mißverständnisse in der Allgemeinpraxis. Diskursanalytische Aspekte der Arzt-PatientKommunikation. In: C urare 9, 297-328.

Rost-Roth, Martina (1994): Verständigungsprobleme in der interkulturellen Kommunikation. Ein Forschungsüberblick zu Analysen und Diagnosen in empirischen Untersuchungen. In: Klein, Wolfgang/ Dittmar, Norbert: Interk ulturelle Kommunikation. Göttingen. (Zeitschrift für Literaturwissenschaft und Linguistik; H. 93), 9-45.

Ten Thije, Jan D. (2002): Stufen des Verstehens bei der Interpretation von Interkulturellen Diskursen. In: Kotthoff, Helga (Hrsg.) (2002): Kultur(en) im $G$ espräch. Tübingen: G unter Narr. (Literatur und Anthropologie; 14), 61-98.

Tzanne, Angeliki (2000): Talking at Cross-Purposes. The D ynamics of Misommunication. Amsterdam/ Philadelphia: Benjamins.

v. Helmolt, K. (1997): Kommunikation in internationalen A rbeitsgruppen. E ine Fallstudie über divergierende Konventionen der Modalitätsk onstituierung. München: iudicium. (Reihe interkulturelle Kommunikation; Bd. 2).

Wimmer, Andreas (2007): H ow (not) to think about ethnicity in immigrant societies: A boundary making perspective. Working Paper No. 44. University of Oxford 2007. (ESRC Centre on Migration, Policy and Society).

Wimmer, Andreas/ Glick Schiller, Nina (2002): Methodological nationalism and the study of migration: Beyond nation-state building. In: International Migra-tion Review 37, 3, 576-610. http:/ / edoc.mpg.de/ 28957.

Winter, Rainer (2003): Kultursoziologie. In: Nünning, Ansgar/ Nünning, Vera (Hrsg.): Konzepte der Kulturwissenschaften. Stuttgart/ Weimar: J. B. Metzler, 93-117. 



\title{
Philosophische Fremdgänge(r): Deutsch-chinesische Begegnungen im 17. und 18. Jahrhundert
}

\author{
A drian H sia
}

\section{Vorbemerkung}

Bevor die Sinologie im Laufe des 19. Jahrhunderts in Europa - zuerst in Frankreich - eine akademische D isziplin wurde, bildeten die Publikationen der Jesuiten die Hauptquellen des Wissens über China, das Land am anderen Ende des eurasischen Kontinents. Seit dem späten 16. Jahrhundert ist eine große Anzahl von Büchern, meistens von Jesuiten verfasst und herausgegeben, in Europa veröffentlicht worden. Mit zu den wichtigsten gehören das von Pater Gonzàles de Mendoza kompilierte und 1585 in Rom auf Spanisch herausgegebene, erste umfassende Buch über das chinesische Reich, das schon bald in sieben andere Sprachen übersetzt wurde. ${ }^{1}$ Der letzte Nachdruck erschien 1663. Matteo Riccis Tagebuch, das 1615 von Nicolas Trigault herausgegeben wurde, ${ }^{2}$ wurde in sechs Sprachen übersetzt und Alvarez de Semedos Geschichte des chinesischen Reichs (1642) ${ }^{3}$ wurde

\footnotetext{
1 Juan G onzalez de Mendoza H istoria de las cosas más notables, ritos y costumbres, del gran reyno de la China, sabidas assi por los libros de los mesmos Chinas, omo por relacion de Religiosos y otras personas ques an estado en el dicho reyno (Roma: Bartholome Grassi 1585). Eine deutsche Teilubersetzung, die N eue Beschreibung des Königreichs China, erschien 1589 in Frankfurt am Main.

2 Nicolas Trigault ist der bekannteste französische Jesuit, der Matteo Riccis 'China Journal' aus dem Italienischen ins Lateinische übersetzt und publiziert hat als D e C hristiana ex peditione apud Sinas suscepta ab Societas Jesu, ex. P. M athaei Rioci eisumdem societatis commentarii (1615).

${ }^{3} \mathrm{D}$ er lateinische Titel lautet Imperio de la China.
} 
in fünf Sprachen übertragen. Diese drei Werke vermittelten ein G rundwissen über die chinesische G eschichte. 1654 erschien das sensationelle Büchlein Historie von dem Tartarischen Kriege wieder die Chineser ${ }^{4}$ von Martin Martini, das die Manchu Eroberung Chinas anschaulich beschreibt. Es wurde ein Bestseller der Zeit und wurde in neun Sprachen übersetzt. Es folgte dann 1667 A thanasius Kirchers C hina illustrata, 5 ein autoritatives Buch, das das China-Wissen der Jesuiten versammelt. Erst 1735 wurde es durch Jean-Baptist du Haldes vierbändigem Werk, der D escription de la Chine, ${ }^{6}$ ersetzt. Bis zum O piumkrieg (1839-42) blieb es das Q uellenbuch über China. Neben den obigen Büchern verdienen zwei weitere jesuitische Publikationen Erwähnung: D ie L ettres édifiantes et curieuses écrites par les missions étrangeres de la C ompanie de Jésus, die zwischen 1702 und 1776 auf 37 Bände anwuchsen und die sechzehnbändigen M émoires concernant l'histoire, les sciences, les arts, les usages des Chinois, die zwischen 1776 und 1814 erschienen. Im katholischen Frankreich übten diese Jesuitenberichte bis in die siebziger Jahre des 18. Jahrhunderts einen großen Einfluss insbesondere auf die Physiokraten aus. Einer von ihnen, François Q uesnay (16941774), war sogar als europäischer Konfuzius bekannt, zwei weitere bekannte Physiokraten waren Anne-Robert-Jacques Turgot (1727-1782) und Voltaire (16941778). Von den protestantischen Philosophen in D eutschland waren es eher die Frühaufklärer Leibniz (1646-1716) und Christian Wolff (1679-1754), die den jesuitischen China-Berichten Glauben schenkten.

In all diesen Fällen der Fremdbegegnung scheint es beinahe gesetzmäßig zu sein, dass immer das rezipiert wird, was nützlich und vorteilhaft scheint. Es geht fast ausnahmslos darum, das eigene positive Selbstverständnis durch das Fremde direkt oder indirekt zu bestätigen, wenn nicht gar aufzuputzen. In der Regel verrät die Rezeption demnach den Rezipienten mindestens genauso wie das Rezipierte, denn das Zentrum ist immer dem Ich vorbehalten. Sowohl bei den Jesuiten als auch bei den späteren Philosophen war dies der Fall.

\section{Sonderstellung Chinas}

Im Prozess der Europäisierung der Welt, der mit dem Entdeckungszeitalter ansetzte und bis heute anhält, ist China eine Sonderstellung vorbehalten. Nach der Entdeckung Amerikas 1492 fiel es Europa nicht schwer, Besitz zu ergreifen. Goa im

\footnotetext{
4 Martini, Martin D e bello Tartario H istoria; in qua quo pacto Tartari hac nostra aetate Sinicum Imperium inuaserint, ac fere totum occuparint, narratur; eorumque mores breviter describuntur. Erster D ruck in Amsterdam, erschien zuerst 1653. D er Jesuit Martino Martini (1614-1661), der seit 1643 als Missionar in Hangzhou in China weilte, wurde vor allem durch die Herausgabe des N ovus atlas Sinensis (1655) bekannt.

${ }^{5} \mathrm{D}$ er vollständge Titel lautet C hina monumentis qua sacris qua profanis, nec non variis naturae \& artis spectaallis, aliarumque rerum memorabilium argumentis illustrata [China illustriert in seinen heiligen und weltlichen D enkmälern], 1667.

${ }_{6}$ Der vollständige Titel lautet D escription geographique, historique, chronologique, politique et physique de l'E mpire de la Chine et de la Tartarie C hinoise.
} 
heutigen Indien wurde 1510 portugiesisch und die Philippinen wurden 1565 spanisch. Rafael Perestrello erreichte 1514 China, aber vom Meer her wurde China nie kolonialisiert. D er Plan, China zu überfallen, wurde von den Spaniern auf den Philippinen geschmiedet. 1586 wurde das Vorhaben gemeinsam vom spanischen Gouverneur, dem Erzbischof von Manila und den Oberen der O rden der Kolonie unterzeichnet und an König Philipp gesendet. Es war ein Jahr nach dem Ausbruch des Anglo-Spanischen Krieges (1585-1604) und Spanien bereitete sich auf eine Invasion Englands vor. 1588 wurde die Armada vernichtend geschlagen und damit wurde der Plan, China zu erobern, aufgegeben. Zu jener Zeit gab es in Manila bereits eine beachtliche Anzahl chinesischer Bewohner, die der Kolonialregierung ein Dorn im Auge waren. Zu Beginn des 17. Jahrhunderts wurden sie kurzerhand massakriert. Berichten zufolge kamen ca. 30000 Chinesen um, die Anzahl chinesischer Siedler durfte 6000 nicht übersteigen. D er Pogrom wurde noch zweimal wiederholt.7

Es wurde deutlich, dass das Vorgehensmuster in Amerika - zunächst Unterwerfung, dann Christianisierung - nicht anwendbar war, denn keine europäische Macht war stark genug, China zu erobern. Es blieb den Missionaren nichts anderes übrig, als die ,heidnische' Sprache zu erlernen, um die Chinesen zum Christentum zu bekehren. Matteo Ricci war einer der beiden Jesuiten, die als buddhistische Mönche verkleidet, nach China entsandt wurden. Mit ihm begann die Akkomodation des Jesuitenordens, die zum so genannten Ritenstreit innerhalb der katholischen Kirche führte. Die Jesuiten sahen in der Ahnen- und Konfuziusverehrung keine religiösen, sondern volkstümliche Riten. Später vermuteten sie gar Berührungspunkte zwischen der konfuzianischen Lehre und dem Christentum. Es galt nicht als ausgeschlossen, dass das Alte China einmal monotheistisch gewesen sei. Erstmals wurde damit eine nicht-europäische Kultur dem stolzen Europa, das die Wilden zivilisierte, als fast ebenbürtig angesehen.

\section{Leibniz' China-Rezeption}

Leibniz (1646-1716) war der erste Philosoph und Aufklärer, der keinen Anstoß an der jesuitischen Perspektive empfand und bereit war, Kulturaustausch mit China, oder genauer mit dem chinesischen Kaiser Kangxi, der zwischen 1661 und 1722 China regierte, anzustreben. Welchen Nutzen und welchen Vorteil mochte sich Leibniz von so einem Austausch versprochen haben? Der Hintergrund ist wie folgt. Im Wesentlichen bestimmten zwei Werke das Chinabild Leibniz': Athanasius Kirchners China monumentis illustrata (1667) und Philippe Couplets Confucius Sinarum Philosophus (1687). Im gleichen Jahr erschien ein Büchlein von Joachim Bouvet unter dem Titel Portrait historique de l'empéreur de la Chine, worin der Jesuitenmissionar den chinesischen Kaiser als Vorbild der aufgeklärten Monarchen vorstellte. D ass

7 Vgl. "Two letters taken out of Barttholomeo Leonardo de Argensola his treatise called Conquista de las Islas M alucas" In: Purchas (1906: Bd. XII, 218-222). 
Leibniz dieser Charakterisierung beipflichtete, ist offensichtlich, denn er nahm sogleich eine lateinische Übersetzung des Porträts in seine N ovissima Sinica (1697) auf und ließ 1699 eine zweite Auslage drucken. Leibniz war überzeugt, dass sich die hohe Stufe der chinesischen Vernunftkultur dem Wirken Kangxis verdankte. Europa, insbesondere ihre erste Kulturnation Frankreich, bedurfte eines solch aufgeklärten Fürsten, der allen Religionen gegenüber tolerant war und beispielsweise die Hugenotten nicht verfolgte.

D och Leibniz befand sich in einem Widerspruch. Einerseits bezeichnete er China als „Europa des O stens" und gleichzeitig als „Anti-Europa“ . ${ }^{8}$ Beide müssten demnach gleichwertig sein. In der Tat vertrat Leibniz die Auffassung, dass die Vorsehung Europa und China - die fortschrittlichsten Kulturen der Welt - an beiden Enden der kultivierten Welt platziert habe. China sei führend in der praktischen Ethik und Politik, da alles auf die Beibehaltung des öffentlichen Friedens und des Zusammenlebens gerichtet sei. Andererseits seien aber die Chinesen nicht wahrhaft tugendhaft und könnten es auch nicht sein, weil bei ihnen die Vorstellung von $\mathrm{G}$ nade und die christliche Lehre fehlten. D er Konfuzianismus reiche nur, um neu sprießende Bösartigkeiten, also kleinere Übel, zu unterbinden. Dennoch sei der konfuzianische Kaiser ein Vorbild der Tugend und Weisheit, was sich besonders darin ausdrücke, dass er das Christentum und dessen Verbreitung in China befürworte. D agegen sei Europa überlegen in den wissenschaftlichen D isziplinen wie Mathematik, Astronomie, Kriegsführung usw. Insbesondere besitze es die Vorstellung der Offenbarung, G nade und Vernunft. Aber auf den Gebieten der praktischen Philosophie und Moral müsse es von China lernen. Man kann sich an dieser Stelle fragen, warum G nade und Vernunft nicht die praktische Moral gefördert haben, die nun von China zu lernen sei.

Für Leibniz stellte China in Wirklichkeit einen Rivalen Europas dar. Er hatte Sorge, dass durch die Missionare sich das ,Europa des O stens' sowohl die Offenbarungsreligion als auch die modernen Wissenschaften aneignen und Europa überflügeln würde. Um einer solchen Entwicklung zuvorzukommen, forderte er deshalb die Entsendung von chinesischen Missionaren nach Europa, um die praktische Philosophie auch in Europa zu verbreiten. Geradezu im gleichen Atemzug erinnerte er wieder daran, dass China höchstwahrscheinlich den wahren Gott gekannt habe, den die Chinesen im Laufe ihrer langen $G$ eschichte jedoch wieder vergessen hätten. Er war ebenfalls der Auffassung, dass die Christianisierung des chinesischen Reichs der größte Erfolg in der Verbreitung des christlichen Glaubens nach der Zeitperiode der heiligen Apostel sein werde. Dieser Zwiespalt, der einerseits den Austausch befürwortet und begrüßt, andererseits eine latente oder gar

8 In ihrem 2003 erschienenen Buch ,A nti-E uropa'. D ie G eschichte der Rezeption des Konfuzianismus und der k onfuzianischen $\mathrm{G}$ esellschaft seit der frühen A ufk lärung (Münster: Lit Verlag) kritisiert die koreanische Politologin Eun-Jeung Lee den Eurozentrismus, worunter sie auch das Christentum fasst; jedoch unterschätzt sie dabei die zentrale Rolle des Christentums. Für fromme Christen war das Christentum die einzige Vernunftreligion. Sie waren fest davon überzeugt, die Vernunft werde von $\mathrm{G}$ ott allein offenbart und ohne diese sei jede Nation und Kultur zur Rückständigkeit verdammt. 
offene Angst vor einer möglichen Rivalität spiegelt, lässt sich in der Vorrede der N ovissima Sinica nachvollziehen. Besonders am Herzen lag Leibniz die religiöse Toleranz Chinas, die sich Europa zu Vorbild nehmen sollte, denn Katholiken und Protestanten sollten einander nicht länger verfolgen.

D ieses Anliegen ist in der zweiten Ausgabe mit ihrer Aufnahme der Schrift Bouvets, in der er den chinesischen Kaiser und das von ihm frisch erlassene Toleranzedikt lobpreist, besonders evident. Louis XIV. sollte sich am chinesischen Kaiser ein Beispiel nehmen. D enn der französische Monarch hatte 1685 das Edikt von Nantes widerrufen, das Henry IV. am Ende des G laubenskriegs (1562-1598) zwischen beiden Konfessionen erlassen hatte und dadurch den Hugenotten zahlreiche Freiheiten einräumte. Dies führte erneut zur Diskriminierung und folglich zum Exodus der Hugenotten. Louis XIV. sollte sich also ein Beispiel am chinesischen Kaiser Kangxi nehmen und diesen Widerruf aufheben. Leider verfehlte die gute Absicht von Leibniz ihren Zweck ganz, denn erst 1787 erließ Louis XVI. ein Toleranzedikt. D ie N ovissima Sinica war - trotz ihrer Berühmtheit in unseren Tagen ein Privatdruck. Anscheinend bestand die erste Ausgabe aus nur vier Exemplaren. ${ }^{9}$ Es ist nicht bekannt, wie groß die zweite Auflage war, eine Leibniz-Forscherin schätzte nach D urchsicht der Korrespondenz des Philosophen, dass beide Ausgaben zusammen nur etwa 50 Exemplare zählten (vgl. Widmaier 2000: 29). Daher hatte dieses berühmte Buch im 18. Jahrhundert wenig Verbreitung. Zwar wurde der Titel oft erwähnt aber wenig gelesen. Erst Franz Rudolf Merkel hat die Schrift 1920 in seiner D issertation analysiert (Merkel 1920).

D ennoch war Leibniz der erste Philosoph in Europa, der die chinesische Kultur ernst nahm und sie nicht, wie die späteren Philosophen, für entwicklungsunfähig hielt. Darüber hinaus war er der einzige Philosoph vor dem 20. Jahrhundert, der sich ausführlich mit dem Neokonfuzianismus auseinandergesetzt hat. Seine Gedanken darüber finden wir in seinem $\mathrm{D}$ isoours sur la théologie naturelle des $\mathrm{C}$ hinois, den er kurz vor seinem Tod niederschrieb, der jedoch unvollendet blieb. Wir müssen uns vergegenwärtigen, dass Leibniz ein frommer Christ war, und die modernen Wissenschaften bestätigten für ihn lediglich die Richtigkeit der O ffenbarungsreligion christlicher Provenienz. Andere Formen von Offenbarungsreligionen, wie den Islam, lehnte er strikt ab. Für Leibniz war die natürliche Theologie Chinas eine Vorstufe der Offenbarungstheologie, die dem Zweck diente, brach und vergessen liegende, christliche Elemente in der chinesischen Überlieferung ausfindig zu machen. Sie sei durchaus imstande, G ott als den Urgrund alles wirklichen und möglichen Seins zu erkennen. Wie auch der gesunde Menschenverstand in der Lage sei, die Unsterblichkeit unserer Seelen zu deduzieren. Die heiligen Mysterien wie die Schöpfung der Welt jedoch könnten nur durch die Offenbarung begreifbar werden, während die Neokonfuzianer vergeblich versuchten, die letzte Wahrheit durch die Logik zu erkennen. Eine Bekehrung zum Christentum würde den Chinesen

${ }^{9}$ D as in der Anna Amalia Bibliothek vorhandene Exemplar der ersten Ausgabe gibt die Anzahl der gedruckten Exemplare als vier an. 
ermöglichen, Gott unmittelbar wahrzunehmen. Hier wird deutlich, dass Europa und China nicht länger als gleichgestellt wahrgenommen wurden. Vom chinesischen Kaiser als Vorbild für europäische Fürsten war nicht mehr die Rede. Es ging um die Voranstellung der Offenbarung gegenüber der natürlichen Theologie und folglich auch der praktischen Philosophie und Moral.10

Man könnte diese Interpretation zwar eurozentrisch nennen, ich finde aber den Ausdruck Christozentrismus treffender. D enn nichts durfte das Christentum in den Schatten stellen. D ass Leibniz die natürliche Theologie auf gewisse Weise gelten ließ, diente u. a. dem Zweck, seine binomische Theorie durch die Yin-Yang Lehre bestätigen zu lassen. Bereits 1697 hatte er an Hand der imago creationes seine binäre Theorie erläutert: Das Bild zeigt starkes Licht, das auf tief dunkles Wasser scheint. Das Licht soll Gott, durch die Eins ausgedrückt, und das Wasser die Null symbolisieren. Leibniz folgerte daraus, dass Gott alles aus dem Nichts geschaffen habe. Er war fest davon überzeugt, dass die gebrochenen Linien, also das dunkle Element Yin, der Null, und die ungebrochenen Linien, das Yang, der Eins entsprächen. Deshalb glaubte Leibniz die alte chinesische Weisheit, die die Schöpfung bestätige, für die moderne Wissenschaft wieder entdeckt zu haben.

D er Neokonfuzianer Z hu Xi (1130-1200) erläuterte seine Anschauungen vor allem anhand der beiden Begriffe Li und Qi sowie deren Zusammenwirken. Diese Begriffe lassen sich nicht genau übersetzen. Li bedeutet in etwa Gesetz, Ursache und Q i könnte als Fluidum, das Fließende, wiedergegeben werden. Leibniz interpretierte ersteres als Gottheit und das zweite als Materie. Diese Auffassung lässt sich mit der christlichen Schöpfungsgeschichte vereinbaren. D amit hatte die Chinarezeption für Leibniz den Zweck der Bestätigung der Suprematie des Christentums und die Richtigkeit seiner binären Theorie erfüllt.

Aufgrund der Ähnlichkeiten zwischen der konfuzianischen und der christlichen Kultur unterstützte er die Akkomodation der jesuitischen China-Mission gegen die Engstimigkeit der anderen Bettel-O rden und Roms. Er regte ebenfalls die Errichtung einer protestantischen China-Mission an, um die Arbeit der Jesuiten zu unterstützen und fortzusetzen. Dies konnte nicht umgesetzt werden, obwohl August Hermann Francke, der Vertreter des Pietismus in Halle, die Idee guthieß. Ausgerechnet in Halle fand wenig Jahre später die Exilierung des Philosophen Christian Wolff statt, weil dieser in einer öffentlichen Rede die praktische Philosophie der Chinesen gepriesen hatte.

\section{Die China-Rezeption Christian Wolffs}

Leibniz starb 1716, ein Jahr bevor die päpstliche Bulle des E x illa die China eindeutig zum heidnischen Land dekretierte. 1742 wurde diese durch die von Papst Be-

10 Rita Widmaier, die auf dem Gebiet Leibniz und China große Verdienste erworben hat, hat die Problematik in ihrem Buch L eibniz' metaphysisches W eltmodell interk ulturell gelesen (2008) anschaulich und ausführlich dargestellt. 
nedikt X IV. erlassene Bulle E x quo singulari bekräftigt, die alles Chinesische verbat. Sieben Jahre nach Leibniz' Tod wurde der Verbreiter seiner Philosophie, der Aufklärer Christian Wolff, auf Betreiben der Pietisten in Halle - wobei der oben erwähnte Francke sich persönlich an König Friedrich Wilhelm I. wendete - aus Preußen verbannt. D ie Kabinettsorder des Königs vom 8. November 1723 zwang Wolff unter Androhung der Strangulation innerhalb von 48 Stunden das Land zu verlassen. Wolff zog nach Marburg. Anlass dieser Strafaktion war eine Rede, die Wolff am 12. Juli 1921 bei der Übergabe des Prorektorats an seinen Nachfolger Joachim Lange gehalten hatte. Eine überarbeitete und erweiterte Version wurde 1726 unter dem Titel 0 ratio de Sinarum philosophia practica gedruckt. Allein dieser Titel zeigt den Unterschied des Rezeptionsrahmens zwischen ihm Wolff und Leibniz: die Verlagerung von der natürlichen Theologie auf die praktische Philosophie der Chinesen. Wolff war stark dem D eismus verpflichtet, in seinen Augen hatte Gott das Naturgesetz geschaffen, das die beste aller möglichen Welten regelt. Es sei absolut und nicht veränderlich, auch nicht durch $\mathrm{G}$ ott. D aher, so der Aufklärer, sei es den Chinesen möglich, das Universalgesetz zu erkennen und ihr Handeln nach ihm zu richten, auch ohne dass sie Gott gekannt hätten. Die Chinesen galten ihm als das einzige Volk, das mittels der autonomen Vernunft zur praktischen Philosophie und natürlichen Moral gelangt sei. Die Frage, ob dann Gott nicht überflüssig ist, stellt sich quasi von selbst. D och soweit wollte oder konnte der Aufklärer nicht schlussfolgern. Für ihn stand fest, dass es der transzendentalen Philosophie bzw. Theologie bedurfte, um zur Vollkommenheit zu gelangen. Ohne sie könnten die Chinesen, wie alle Menschen, nur die untersten Stufen der Tugend erreichen. Fraglos kannten nur die Christen den Schöpfer des Naturgesetzes und der Natur, China musste demnach naturgemäß Europa gegenüber minderwertig sein. All dies hinderte Wolff jedoch nicht daran, China als Musterland zu betrachten. Diesen Widerspruch könnte man vielleicht dadurch erklären, dass trotz gegenteiliger Beweisführung, Europa gefühlsmäßig über allem stand.

Wolff interessierte sich für das Staatswesen. Er wollte ein Modell aufstellen, das nicht utopisch, sondern realisierbar war. Wichtig war ihm ein Ausgleich zwischen dem $\mathrm{G}$ emeinwohl und dem Glück des Einzelnen. Bezeichnenderweise befürwortete er den konfuzianischen Grundsatz, wonach sich der Einzelne zuerst selbst vervollkommnen und dann die Familie und die Beziehungen der Menschen untereinander regeln sollte, was letztlich hin zu einem wohlgeordneten Staatswesen führe. Die Familie als Keimzelle des Staates und dieser sei gleichsam eine riesige Familie. So wie das Staatsoberhaupt sei auch der Einzelne von Natur aus dafür bestimmt, nach Tugend zu streben. Die Legitimität des Regierenden gehe verloren, wenn er vom Pfad der Tugend abkomme und das $\mathrm{G}$ emeinwohl aus dem Augen verliere. Denn im konfuzianischen Denken gebe es den Grundsatz, ein Volk sei wie das Wasser, es könne ein Boot tragen, aber es auch umkippen. Wie die Konfuzianer betrachtete auch Wolff die chinesischen Sagenkönige Yao und Shun als Musterregenten, die ausschließlich für das $\mathrm{Gemeinwohl} \mathrm{gelebt} \mathrm{und} \mathrm{gewirkt} \mathrm{haben.} \mathrm{In} \mathrm{die-}$ sem Sinne sei Konfuzius, so Wolff, nicht der Begründer der Lehre, die seinen Na- 
men trage, sondern der größte Lehrer der uralten Sittenlehre Chinas. Wolff verglich Konfuzius nicht nur mit Moses im Alten Testament, Mohammed im Islam, sondern auch mit Jesus im Neuen Testament (vgl. Wolff 1985: 19) - keine größere Ehre konnte ihm zuteil werden. D ass die Pietisten so einen Vergleich als eine tödliche Versündigung gegen den Heiland empfanden, lag in der Natur der Sache, auch wenn Wolff trotz allem meinte, die Chinesen bedürften der göttliche $\mathrm{G}$ nade, um zu einer höheren Vollkommenheit zu gelangen. D enn schon Konfuzius habe über sich selbst gesagt, dass er nicht vollkommen sei (Wolff 1985: 159).

\section{Der Paradigma-Übergang: Montesquieu}

Wolffs Vertreibung aus Preußen war relativ bekannt. In aufgeklärten Kreisen fand er Unterstützung, kaum aber in kirchlichen. Sicherlich hatte Wolff seine Anhänger, fraglich ist jedoch, wie verbreitet die Akzeptanz seiner fremden Ideenwelt tatsächlich war. Neuere politische Ideen von Montesquieu (1689-1755) und Jean Jacques Rousseau (1712-1778) kamen bald hinzu. Besonders die Schrift D e l'esprit des L oix (1748) wurde sehr schnell berühmt. In diesem einflussreichen Werk über die Gewaltenteilung des modernen Staates ordnete Montesquieu China dem D espotismus zu, den Grund sah er im Klima. Die extreme Hitze in China schwäche sowohl die Körperkraft als auch den Mut der Chinesen, was sie weibisch und damit unwiderruflich zu Sklaven mache. Montesquieu war stolz darauf, als erster den Zusammenhang zwischen K lima und Nationalcharakter entdeckt zu haben. Er konstatierte weiter, in Asien gebe es schwache und starke Länder, wobei die schwachen, trägen und weibischen Nationen von den starken erobert und versklavt würden. Anders dagegen verhalte es sich in Europa, wo starke Ländern gegenüber anderen starken Ländern aufträten. D er G rund liege darin, dass in Asien Sklaverei und in Europa Freiheit herrsche. Für Montesquieu stand fest, dass die Asiaten von Natur aus Sklaven seien. Wenn die starken asiatischen Länder die schwachen Länder eroberten, täten sie dies dennoch als Sklaven. D enn der D espotismus mache alle zu Sklaven und China sei hier beispielhaft. Die Manchus im Norden haben zwar die sklavischen Chinesen im Süden erobert, würden aber dennoch nicht zu Herren, da sie ebenfalls von Despoten regiert würden, vielmehr würden sie sklavischer als zuvor. Dies sei ein unveränderliches Naturgesetz. An späterer Stelle führt er dann aus, dass im Europa der starken Länder Freiheit herrsche, weshalb dort keine Fremdherrschaft erfolgreich sein könne, sondern Herrschaft allein über G esetze und vorteilhaftes Handeln.

Die Frage, wie Montesquieu zu diesen Feststellungen kam, drängt sich auf. In ihrer Studie (D odds 1929), in der sie die Quellen für Montesquieus D enken untersucht, stellt Muriel Dodds zuerst fest, dass der Philosoph von seiner Theorie ausgehend nach Belegen suchte und diese auch fand. So sollen seine Ideen zum D espotismus von Paul Ricauts H istoire de l'E tat présent de l'E mpire 0 ttoman (1670) herrühren, die er nicht nur auf China, sondern auf ganz Asien übertrug. Was China 
anbetrifft, so verwies er auf das von Richard Walter aufgezeichnete Buch V oyages around the W orld in the years M D CCX L, I,II,III,IV . By G eorge A nson, das 1748 gedruckt worden war. Dieses Buch erregte großes Aufsehen und wurde viel gelesen und zitiert, u. a. auch von Montesquieu. Anson war ein britischer Admiral, der mit einem gekaperten spanischen Schiff in Macao und Kanton gelandet war. Er als Person, aber auch sein Buch verkörperten den neuen Zeitgeist des Handels und der Eroberung:

Indeed thus much may undoubtedly be asserted that in artifice, falsehood, and an attachment to all kinds of lucre, many of the Chinese are difficult to be paralleled by other people... I may not be thought too severe in ascribing to this Nation a fraudulent and selfish turn of temper, so contradictory to the character given of them in the legendary accounts of the Romish Missionaries. (Anson 1780: 506)

Dies wurde die Basis der neuen China-Perzeption. Dazu prägte Montesquieu den passenden Slogan: „La Chine est donc un Etat despotique dont le principe est la crainte." (Kapitel 21) China wurde, zusammen mit den übrigen orientalischen Ländern wie Indien und der Türkei, Ehre und Tugend abgesprochen. In der Satire „D er Kaiser von China“, von Heinrich Heine spiegelt sich diese Einschätzung wider. Heine krönte Friedrich Wilhelm IV. als Kaiser von China, der mit seinem Konfuzius, also Schelling, das Land regierte. D ieser Kaiser wollte die hohe Pagode, d.h. den Kölner D om, vollenden, alle Juden taufen und seine Untertanen mit der Peitsche glückselig machen.

\section{China-Rezeption der Göttinger Historiker}

Wie groß der Einfluss Montesquieus in D eutschland war, lässt sich bei drei Historikern der (1734) neu gegründeten $G$ öttinger Universität erkennen, nämlich Johann Gottlieb Gatterer (1727-1799), August Ludwig Schlözer (1735-1809) und Christoph Meiners (1747-1810). Mit Ausnahme von Gatterer haben sie Montesquieus Theorie des D espotismus positiv rezipiert und Voltaire (man nennt die Aufklärung auf Englisch u. a. "the Age of Voltaire“) alle drei abgelehnt. Sie waren auch der Meinung, dass die zeitgenössische Höhe der europäischen Kultur dem freien Handel zu verdanken sei. Es ist evident, dass der Handel den neuen Zeitgeist definiert, gleichzeitig wissen wir, dass die Kaufleute im konfuzianischen China den niedrigsten gesellschaftlichen Rang besaßen und China mit dem neuen Zeitgeist wenig Berührungspunkte hatte. Dass das zeitgenössische China nach wie vor Konfuzius verehrte, „,wurde dahingehend interpretiert, daß China seit seiner [d.h. des Konfuzius] Zeit keinen Fortschritt mehr erzielt habe", wie Eun-Jeung Lee richtig feststellte (Lee 2003: 223). Eine weitere $G$ emeinsamkeit der drei bestand darin, dass sie das A lte Testament als die Quelle der G eschichte der Menschheit und den Konfuzianismus nicht mehr als eine Moral- und Staatsphilosophie, sondern als eine heidnische Religion betrachteten. Vor allem aber sahen sie in D eutschland den Gipfel der 
Aufklärung der Menschheit. Vor dem Hintergrund der neuen D efinition des Despotismus, des neuen Zeitgeistes, dem unverrückbaren Glauben an die Bibel und dem neuen Selbstvertrauen war eine positive Rezeption Chinas nicht mehr möglich. Gatterer, der älteste der drei, identifizierte Noah mit dem chinesischen Sagenkönig Fuxi und gestand den Chinesen noch ein wenig Aufklärung zu. Er war der einzige der drei Historiker, der den chinesischen Kaiser nicht als D espot und die Chinesen nicht ausschließlich negativ beschrieb. In seinen Augen waren sie „sanft und phlegmatisch, aber doch sehr arbeitsam und zu allem geschickt, zur Verstellung und heimlichen Rache geneigt, schamhaftig und eingezogen, mäßig und vorsichtig, im Handel und Wandel eigennützig und betrügerisch." (G atterer 1764: 333; zit. nach Lee 2003: 192)

Für den acht Jahre jüngeren Schlözer, für den Montesquieu und Rousseau maßgebend waren, waren die Chinesen gemeinsam mit den Marrokanern lediglich „Halbmenschen“ (Schlözer 1775: 122, vgl. Lee 2003: 202). D as war im Jahr 1775. Vierzehn Jahre später nannte er sie „D ummköpfe“ (Schlözer 1798: 332) und China „das größte, aber auch - da ihm Klima, Sitten und unmenschliche D espotie keinen Gebrauch seiner ungeheuren Kräfte gestatten - zugleich das dümmste Reich der Welt" (Schlözer 1775: 122, vgl. Lee 2003: 202f.). Für ihn war Konfuzius nur „ein finsterer Schwärmer" (Schlözer 1775: 130) und "Stoppler" (Schlözer 1775: 6). Er war einerseits gegen die Sklaverei, andererseits aber auch für die Kolonialisierung, da so die Aufklärung verbreitet würde. Wörtlich sagte er: „Spanier und Britten haben diese Europäischen Künste, den Erdkreis zu schönern, übers Meer in neue Welten getragen; in dem Laufe von Jahrtausenden wird Kanada werden, was itzo D eutschland ist." (Schlözer 1772: 13, zitiert nach Lee 2993: 203). D er wiederum jüngere Meiners, 20 Jahre jünger als G atterer und 12 Jahre als Schlözer, wurde zunächst durch seine Übersetzung des ersten Bandes von M emoires onœernant l'H istoire, les Sciences, les A rts, les M oeures... des Chinois, bekannt. Die Übersetzung erschien 1778, zwei Jahre nach dem französischen O riginal, und zwar ausschließlich zum Zweck, die Ausführungen im O riginal durch Anmerkungen zu widerlegen.

In seinem Hauptwerk, dem G rundriß der G eschichte der Menschheit, das 1785 herauskam und 1793 wieder aufgelegt wurde, teilte er die Menschen in zwei Stämme ein, die Kaukasier und die Mongolen. Zu Letzteren rechnete er alle, in seinen Worten, farbigen und hässlichen Völker außerhalb Europas. Farbig und hässlich sind dabei mehr oder weniger synonym mit physischer und geistiger Schwäche sowie fehlende Tugenden. Zu den Kaukasiern zählte er die Kelten und die Slawen. Unter den Kelten, schreibt er in einer anderen Arbeit (Meiners 1791: 119f.), seien die „Teutschen“ die vollkommensten. Sie sollen eine blendend weiße Haut, blondes, lockiges Haar und blaue Augen haben. Sie sollen größer, stärker und schlanker gebaut sein als alle übrigen Völker. Zudem seien sie mutig und freiheitsliebend, erfinderisch und tugendhaft. Dagegen seien die Völker des mongolischen Stammes dunkel, hässlich, fett, bartlos, tugendleer, extrem reizbar, gefühllos, selbstsüchtig, feige, furchtsam, grausam und filzig. Der geistigen und körperlichen Schwäche wegen hätten sie eine natürliche Neigung zum D espotismus. D ieser sei ihnen von 
Natur aus ein ewiger Zustand (Meiners 1793: 204). Diese Völker, zu denen er die Chinesen zählte, seien nichtswürdig und den Tieren nah. Meiners vermutete, dass diese Halbmenschen zu einer früheren Schöpfung gehörten. Später wird F. W. J. Schelling (1775-1854) dieselbe Feststellung treffen, wenngleich in einem anderen Zusammenhang (vgl. Hsia 2008: bes. 201-208). Aufgrund der natürlichen Ungleichheit der Völker sprach sich Meiners für den Kolonialismus mit unumschränkter Gewalt (Meiners 1793: 219), die er sogar für heilsam und notwendig hielt, aus. Dieser sei ein Beitrag „zur Vervollkommnung und Beglückung“ (Meiners 1790: 643) der Kolonialvölker, wenngleich diese dennoch niemals gleich werden könnten, denn das wäre widernatürlich.

D ie D arstellung der obigen drei Universalhistoriker galt der Veranschaulichung eines sich wandelnden Zeitgeistes. D ie Natur erfuhr eine drastische D egradierung, so dass die natürliche Theologie und Sittenlehre der Chinesen nicht mehr von Interesse und Bedeutung waren. Die Offenbarung und G nade wurden allmählich durch die von ihnen abhängige Vernunft ersetzt, die sich eindeutlich von der Natur abgrenzte. Auch ist die Tendenz zu beobachten, dass man zwar nach wie vor die Monogenese der Menschheit anerkannte, doch sprach man von Menschenrechten, waren damit ausschließlich die Europäer gemeint. Dies hatte zur Folge, dass die Sklaverei zumindest stillschweigend geduldet und Kolonialismus als dem Fortschritt der Kolonialisierten dienlich befürwortet wurde. Ebenfalls galt der Handel als Voraussetzung für eine zivilisierte G esellschaft und als Mittel zur Förderung der Aufklärung. Es sei daran erinnert, dass Baumwollprodukte, Sklaven und später O pium Massenwaren des Handels waren. Bemerkenswert ist auch, dass es neben der D ifferenzierung von Europäern und Halbmenschen auch innerhalb der ersten noch Rangunterschiede gibt. An der Spitze die Germanen, dann die übrigen, so genannten Kelten und an letzter Stelle die Slawen, was später zu ernsten Konsequenzen führen sollte. D er Zeitgeist zeigte sich in seiner Bedeutung jedoch nicht nur bei den Weltgeschichtler, sondern auch bei den Philosophen. Zwei Zeitgenossen der obigen Historiker waren Kant (1724-1804) und Herder (1744-1803), jeweils drei Jahre früher geboren als $\mathrm{G}$ atterer und Meiners.

\section{China-Rezeption Kants}

Es ist bekannt, dass Kant die Ungleichheit der Rassen akzeptierte. Hierin folgte er dem schottischen Philosophen David Hume (1711-1776), der in der Hautfarbe die Intelligenz widergespiegelt sah: je dunkler je dümmer. Über die Uramerikaner, die wir heute Indianer nennen, schreibt Kant in „Von den verschiedenen Racen der Menschen“ (Kant 438f.), dass sie kupferbraun seien, weil sie ursprünglich von Nordasien stammten und deshalb im ewigen Halbwinterschlaf lebten. Folgerichtig taugten sie nicht als Sklaven, welche man stattdessen aus Afrika importieren müsse (ebd.). D ieser Tatsache gegenüber war Kants Position völlig neutral, als ob sie moralisch irrelevant sei. Die eigentlichen Inder wurden der gelben Rasse zugeschrie- 
ben. D agegen seien die Chinesen an sich gelbe Mestizos, eine Halbrasse gemischt aus Indern, Skythen und Hunnen. D emnach seien sie den weißen Rassen, wie den Germanen, die mit „zarter weißer Haut, röthlichem Haar, bleichblauen Augen” (Kant 441) versehen seien, nachgeordnet.

Zwischen 1756 und 1796 hielt Kant zwar nicht jährlich, aber doch regelmäßig die Vorlesung über die physische $\mathrm{G}$ eographie, die auch die verschiedenen Völker der Kontinente einschloss. Seine Vorlesungsnotizen, die als Diktattext bekannt sind, sowie einige Nachschriften sind überliefert, sodass wir uns ein Bild seiner Meinungen zu China machen können. ${ }^{11}$ Im genannten Zeitraum lehrte Kant seinen Studenten, dass das Schönheitsideal der Chinesen beiderlei Geschlechts ein langer und fetter Körper sei. Die Stirn müsse breit und die Nase kurz, die Augen müssten klein und die O hren hingegen groß sein. Bei einem Mann sagt er einerseits, er soll einen großen Bart haben, andererseits aber auch, der Mann ziehe „sich mit Zänglein die Barthaare aus und läßt nur einige Büschlein stehen" (Kant/ Glasenapp 84). Und weiter: Sie seien ungemein rachsüchtig, jedoch sehr geduldig in der Ausführung des Racheakts. Sie ließen sich nie auf ein Duell ein. Weiterhin seien sie „feige, sehr arbeitsam, sehr untertänig und den Komplimenten bis zum Übermaße ergeben" (Kant/G lasenapp 84). Sie seien von Natur aus betrügerisch veranlagt und schämten sich nur, wenn sie sich dabei durch ihr Ungeschick ertappen ließen. D ie Frauen hätten kleine Füße und würden immer die Augen niederschlagen. Ihre Hände würden sie niemals zeigen. Ansonsten seien sie "weiß und schön genug" (Kant/G lasenapp 84). Hier erkennen wir einige Ähnlichkeiten in der D arstellung mit den Göttinger Historikern.

Kant versuchte mit Objektivität die Lage der Religionen in China darzustellen und unterteilte die Chinesen in grundsätzliche und funktionale Atheisten. Die ersteren seien Atheisten an und für sich, die letzteren glaubten zwar an die Existenz Gottes, ohne ihn jedoch anzubeten. Er nahm an, dass die meisten Chinesen der Lehre Buddhas folgten. Sein Verständnis von Buddhismus war noch sehr rudimentär und fehlerhaft. Kant identifizierte den Dalai Lama mit Buddha, der in Lhasa throne und nach dem Tod reinkarniert würde. Er berichtete auch, der Buddhismus sei, einigen jesuitischen Berichten zufolge, ein degeneriertes, dem Heidentum verfallenes Christentum. Er selbst glaubte, dass der Buddhismus eine Art von Trinität kenne, da der zweite buddhistische $\mathrm{G}$ ott, laut Kant, für die Menschheit sein Leben gelassen habe. Er berichtete ebenfalls, dass der D alai Lama eine heilige Zeremonie mit Brot und Wein zelebriere, ohne diese jedoch näher zu beschreiben. Er wusste auch von Konfuzius und nannte ihn mit den Jesuiten den chinesischen Sokrates, ohne sich für seine Person oder Lehre zu interessieren. D er daoistische Philosoph Lao Zi (Lao Tzu), den er Laokium nannte, interessierte ihn dagegen weit mehr. Leider war sein Wissen über Lao Zi und dessen Werk zu Kants Zeit mangelhaft, denn die Jesuiten hatten wenig Interesse für ihn, weil sich ihre gesamte Missions-

11 Hier stütze ich mich hauptsächlich auf die Rekonstruktion von Texten und Information von von Glasenapp (1954). 
arbeit darauf konzentrierte, den Konfuzianismus mit dem Christentum zu harmonisieren. Kants Kommentare, die wir in der Abhandlung „D as Ende aller Dinge“ (Kant 1970, Bd. 9: 175-190) finden, reflektiert sowohl diesen Wissensstand, als auch eine gewisse Feindseligkeit, welche die Jesuiten Lao Zi gegenüber empfanden.

In der Abhandlung unterscheidet Kant drei Arten vom Ende aller Dinge: 1. Das natürliche Ende, das in der Ordnung der moralischen Zwecke in Übereinstimmung mit der göttlichen Weisheit ist; 2. das mystische Ende, das schlechthin unverständlich ist; 3. das unnatürliche Ende, das von uns selbst herbeigeführt wird. Lao Zi gilt als Mystiker. Es liegt daher nahe, dass Kant Lao Zis Lehre als monströs bezeichnet, da bei dem chinesischen Weisen das höchste Gut das Nichts sei, $d . h$. im G efühl eins mit der Unendlichkeit Gottes zu sein, indem man seine eigene Persönlichkeit zerstört und diejenige G ottes annimmt.12 Um sich für dieses letzte Stadium vorzubereiten schlössen sich chinesische Mystiker in dunklen Räumen ein, wo sie sich mit geschlossen Augen darauf konzentrierten, das Nichts zu fühlen. Kant meinte, dass diese Praktik an den Pantheismus der Tibeter und anderer orientalischer Völker, d. h. der Buddhisten, erinnere. Eine Ähnlichkeit stellte er auch mit dem Spinozismus fest, ohne aber diesen Punkt zu erläutern. Er hob hervor, dass das Stadium der „ewigen Stille“ keineswegs das Ende aller Dinge, sondern nur das Ende des Denkens sei. Dies sei bezeichnend für den chinesischen $\mathrm{G}$ eist.

In vier Hauptpunkten konzentrierte Kant seine Kritik gegen China. Er konstatierte, dass die Chinesen in ihren Wissenschaften niemals zu klaren Konzepten gekommen seien und auch nie kommen werden. Diese Unfähigkeit teilten die Chinesen seiner Ansicht nach mit den Indern (Kant/ Glasenapp 23)13 und allen asiatischen Nationen (Kant/ Glasenapp 27). ${ }^{14}$ Für ihn war das Fehlen der Schatten in der chinesischen Tuschemalerei ein fester Beweis dafür, dass die Chinesen konfus dächten. Als weitaus schlimmer befand er die Tatsache, dass sie 80000 Schriftzeichen bräuchten, um sich verständlich zu machen, ${ }^{15}$ während man in Europa nur 24 benutze. Ein Chinese könne erst die nötigen Zeichen beherrschen, wenn er bereits den Zustand der Senilität erreicht habe. Auch dass er angeblich nie seine Heimat verlasse und in die Fremde ziehe, sei ein weiterer Nationalfehler. Erst im 20. Jahrhundert ist allmählich bekannt geworden, dass China knapp einhundert Jahre vor Kolumbus die größten Schiffe der Welt gebaut und die größte Flotte mit einer Besatzung von 20000 Mann bis nach Afrika gesendet hat. D en letzten Beweis dafür,

\footnotetext{
12 „D as Ende aller D inge“, in: W erke, Bd. 9, S. 185.

13 Er schreibt: „Sie haben wohl Künste, aber keine eigentlichen Wissenschaften. “, S. 23.

14 Kant sagt wörtlich: „D ie asiatischen Nationen haben ihren Stillstand da, wo die Erweiterung ihrer Vollkommenheiten aus Begriffen geschehen mußte und nicht bloß aus Anschauungen. “, S. 27.

15 Kants Meinungen über die chinesische Sprache waren nicht konstant. Im Diktattext schreibt er auch einmal, die chinesische Sprache habe 53000 Zeichen und ein G elehrter benötige 20000 . Auch hat er den Erfinder des chinesischen Schriftsystems gelobt, eine Art Einheitssystem für jene Region der Welt entwickelt zu haben. Dann meint er, ein Chinese müsste die Schriftzeichen bis zum Einsetzen der Senilität lernen und daher alle anderen Wissenszweige vernachlässigen. D iese unterschiedlichen Urteile gehen auf die Uneinheitlichkeit seiner Q uellen zurück.
} 
dass die Chinesen keine klaren Konzepte hätten, sah Kant darin, dass sich der Sitz ihres religiösen O berhauptes, nämlich des D alai Lama, außerhalb Chinas befinde.

Von den chinesischen Wissenschaften berichtete Kant, dass ihre Voraussage von Sonnen- und Mondeklipsen trotz der uralten astronomischen Traditionen sehr fehlerhaft seien. Sie seien nur imstande, den Tag, aber nicht die Stunde einer Finsternis auszurechnen. Was Kant kurios fand, ist die Tatsache, dass die Chinesen trotz ihrer astronomischen Wissenschaft noch daran glauben konnten, dass eine Eklipse auftrete, wenn ein D rache die Sonne oder den Mond verschlucke. Um den D rachen zu verjagen, schlügen die Chinesen auf alles ein, um Krach zu machen. Diese Sitte versuchte Kant rational zu erklären. Er nahm eine Tradition in grauer Vorzeit an, die von den Chinesen, die an dieser Überlieferung hingen, nicht aufgegeben werden wollte. D ieser Erklärungsversuch zeigt, dass er nicht unüberlegt auf Klischees zurückgriff, wenngleich mangelnde Kenntnisse bestehende Vorurteile eher verstärkten und zeigen, dass sich auch ein großer D enker nicht über Zeit und Raum erheben kann. Er mag zwar ausgehend von vorhandenem Wissen zu neuen Bereichen vorstoßen, aber kollektive Vorurteile verleiteten ihn zu Fehlschlüssen und -erkenntnissen. Am Ende stand China für Kant als ein Land ohne Fähigkeit zur Tugend- und Pflichterfüllung da. D ie physische Geographie war für Kant nur ein Nebenprodukt und er hatte nie beabsichtigt, sie zu publizieren. D as Wissen, das er in diesem Bereich akkumulierte, hatte er nie zu systematisieren versucht. D er Diktattext und die Nachschriften können sich durchaus widersprechen, da sie aus verschiedenen Zeiten stammen und die Informationsquelle der Reiseberichte immer unzuverlässiger wurde. Wenn sich seine Überlegungen auf Jesuitenberichte stürzten, kam Kant meistens zu positiven Ergebnissen, ansonsten waren seine Beschreibungen negativ.

\section{China-Rezeption Herders}

Ähnlich verhielt es sich bei Herder, der Hörer der Kantschen Vorlesung zur physischen $\mathrm{G}$ eographie war. Herder jedoch schrieb bewusst seinen Text für die Publikation. Zudem bemühte er sich, an Hand der vorhandenen positiven und negativen Quellen über Land, Kultur und Volk Chinas ein neutrales Chinabild zu schaffen. Bewusst strebte er danach, zwischen den beiden Lagern zu vermitteln. Welchen Perzeptionsrahmen brachte er mit für diese Aufgabe? Er glaubte an die Schöpfungsgeschichte, wie sie die $\mathrm{G}$ enesis darstellt. Das war an sich kein Hindernis, denn die jesuitischen Figuristen, wie beispielsweise Bouvet, taten dies auch. So auch Leibniz. Herder lehnte jede Rassentheorie ab. Für ihn gab es nur eine Menschheit. $\mathrm{D}$ afür war er aber fest von der Klimatheorie Montesquieus überzeugt. Er war strikt gegen jede Art von Ausbeutung und Gewalt, akzeptierte jedoch den Verlauf der Geschichte, 16 wovon Kolonialismus ein Teil darstellte. Er glaubte ferner an die

16 Vgl. Herders Meinung: „Harter Lauf des Schicksals der Völker! Und doch ist er nichts als Naturordnung“ und der Abschnitt über Indien endet mit ähnlichen Worten: „Indessen ist die Kette des 
Vorsehung und die Bestimmung der Menschheit sich zu einem höheren, engelähnlichen Wesen hin zu entwickeln und war naturgemäß verstimmt über jede Verzögerung. Da nun die Chinesen, in Herders eigenen Worten, „einbalsamierten $\mathrm{Mu}$ mien" glichen, die nicht länger entwicklungsfähig seien, galten sie als das Haupthindernis für die Menschheit das nächste Stadium zu erreichen. Herders Chinabild gilt es nun unter diesen Widersprüchlichkeiten zu betrachten.

A usgenommen von Herders Ablehnung der Rassetheorien schienen in der antiken Welt die Ägypter und in der modernen Welt die Kalmücken bzw. Mongolen zu sein. Die Klimatheorie von Montesquieu zitierend, den Herder bewunderte und als groß bezeichnete (Herder 185)17 und unter Hinzuziehung des Begriffs vom „inneren Klima“, d. h. der genetischen Kraft (Herder 188), suchte er den beiden und verwandten Völkern innewohnende Mängel nachzuweisen. Zu ihnen zählte er auch die Chinesen. Für Herder waren die Mongolen und Kalmücken manchmal Raubtiere und manchmal Heuschrecken (Herder 180). Sie hätten ein plattes Gesicht, einen dünnen Bart, schiefe Augenwinkel, fast ungebogene Augenbraunen, eine kleine, platte und zu breite Nase, abstehende große O hren, krumme Schenkel und Beine sowie ein weißes, starkes G ebiss (Herder 157). Er erklärte genau, wie diese G estalt entstanden sei: „D ie gebognen Knie und Beine finden ihren Grund in der Lebensweise des Volkes. Von Kindheit auf rutschen sie auf ihren Beinen oder hangen auf dem Pferde [...] der $\mathrm{G}$ ang ist ihnen bis auf wenige Schritte sogar fremde [...]. D as abstehende tierische $\mathrm{O} h r$, das gleichsam immer lauscht und horchet, das kleine scharfe Auge, das in der weitesten Ferne den kleinsten Rauch oder Staub gewahr wird, der weiße hervorbleckende, knochenbenagende Zahn, der dicke Hals und die zurückgebogene Stellung des Kopfes ..." (Herder 157) seien Resultate ihrer Lebensweise. Außerdem sei ihnen das Baden „beinah eine ganze fremde Sache“ (Herder 158) und sie tränken ständig Tee. Herder war der festen Überzeugung, nichts würde den Körper mehr schwächen als das warme $\mathrm{G}$ etränk (Herder 158). Die Chinesen stammten von den Mongolen ab und gebrauchten nicht das Alphabet, sondern eine Art von Hieroglyphen wie die Ägypter: eine unbedingte Schwäche und zum Nachteil der menschlichen Entwicklung. Für Herder war die Sprache eine besondere $\mathrm{G}$ abe $\mathrm{G}$ ottes, welche die Aufklärung der Menschheit, eine Voraussetzung zum höheren Wesen, erst möglich mache. ${ }^{18} \mathrm{D}$ urch die mongolische Abstammung hätten die Chinesen aber ein überscharfes Gehör („Nur ein mongolisches O hr konnte darauf kommen...", Herder 282). Dies habe zur Folge gehabt, führte er weiter aus, dass das Chinesische nur 330 Silben bzw. Laute mit fünf Akzenten bzw. Tönen kenne. Herder war überzeugt, dass „europäisches $\mathrm{Ohr}$ und

Schicksals dahin einmal geknüpft; das Schicksal wird sie auflösen oder weiterführen." Siehe Herder, Ideen zur Philosophie der G eschichte der M enschheit, Riga: Hartknoch, 1784-1792. Ich benutze die Ausgabe des Fourier Verlags in Mainz (1985), hier S. 295.

17 Die Seitenzahl der zitierten Stellen von Mainz 1985 wird in runden Klammern angegeben.

18 Vgl. Kapitel 3 des vierten Buches mit der Überschrift „der Mensch ist zu feinern Sinnen, zur Kunst und zur Sprache organisiert". U. a. schreibt er: „D er Mensch der Erde ist noch ein Zögling des O hrs, durch welches er die Sprache des Lichts erst verstehen lernet." (Herder 117) 
europäische Sprachorgane sich äußerst schwer oder niemals an diese hervorgezwungene Silbenmusik gewöhnen" könnten (Herder 282). Er glaubte, die fehlerhafte Sprache sei auf die chinesischen Eigenschaften, nämlich auf den „Mangel von Erfindungskraft im Großen“ und die "unselige Feinheit in Kleinigkeiten“ zurückzuführen. D azu kämen noch die 80,000 Schriftzeichen von mindestens sechs „Schriftarten". Herder war überzeugt, dass die Hieroglyphen eine negative Wirkung auf die Seele ausübten. D enn jene würden „die Gedanken zu Bilderzügen“ entnerven und "die ganze Denkart der Nation zu gemalten oder in die Luft geschriebenen willkürlichen Charakteren" (Herder 285) machen. Wer nicht klar denken kann, kann nicht aufgeklärt werden. Die Aufklärung ist aber die Voraussetzung für die weitere Entwicklung der Menschheit. Herder glaubte, die mongolische Abkunft der Chinesen beeinträchtige nicht nur das Gehör, die Sprache und das Aussehen der Chinesen, sondern auch ihre Mentalität und D enkweise. Er drückte sich so aus:

Eine mongolische O rganisation gehörte dazu, um sich in der Einbildungskraft an D rachen und Ungeheuer, in der Zeichnung an jene sorgsame Kleinfügigkeit unregelmäßiger $\mathrm{G}$ estalten, in den Vergnügungen des Auges an das unförmliche Gemisch ihrer Gärten, in ihren $G$ ebäuden an wüste $G$ roße oder pünktliche Kleinheit, ihren Aufzügen, Kleidungen und Lustbarkeiten an jene eitle Pracht, an jene Laternenfeste und Feuerwerke, an lange Nägel und zerquetsche Füße, an einen barbarischen Troß von Begleitern, Verbeugungen, Zeremonien, Unterschieden und Höflichkeiten zu gewöhnen. (Herder 282)

Es sei natürlich unmöglich für so ein Volk, einen Sinn von „innerer Ruhe, Schönheit und Würde" zu besitzen. Die verwahrloste mongolische Empfindung bringe es mit sich, dass den Chinesen, "wie mehreren Nationen dieser Erdecke“, (Herder 283) gemeint ist O stasien, „die Gabe der freien, großen Erfindung in den Wissenschaften ... die Natur versagt zu haben" (Herder 282-3) scheint. Was ihnen hingegen zuteil würde, seien „jene listige Betriebsamkeit und Feinheit, jenes Kunsttalent der Nachahmung in allem, was ihre Habsucht nützlich findet" (Herder 283). Weil sich die Chinesen, wie die Juden (Herder 283), nicht mit anderen Völkern gemischt hätten, seien sie „ein mongolischer Stamm“ geblieben, dessen Sitten „zur chinesischen Sklavenkultur verartet" (Herder 283) seien. D ie G rundtugend dieser Kultur sei der kindliche $\mathrm{G}$ ehorsam, der auf Befehl ruht, sowohl in der Familie als auch im Staat. Männliche Kraft und Ehre seien den Chinesen fremd, es handle sich stets nur um kindliche Pflichten und leere Zeremonien. D er kriegerische und denkende G eist würden ihnen nicht zuletzt fern bleiben, weil sie auf "warmen Ö fen" schliefen und „vom Morgen bis zum Abend” (Herder 284) warmen Tee tränken.

Allmählich fasste Herder seine Meinungen zusammen. Er sprach das Urteil aus, dass die chinesische Kultur "Jahrtausende hindurch auf derselben Stelle", (Herder 284), nämlich „im Knabenalter" (Herder 286) stehen geblieben sei. In diesem Zusammenhang machte er seinen bekannten und oft zitierten Spruch über China: 
D as Reich ist eine balsamierte Mumie, mit Hieroglyphen bemalt und mit Seide umwunden; ihr innerer Kreislauf ist wie das Leben der schlafenden Wintertiere. (Herder 284)

Ist das die goldene Mitte, auf die Herder zielen wollte, um möglichst objektiv über China zu berichten? G egen Ende des China-Kapitels scheint er sich an seinen ursprünglichen Grundsatz zu erinnern und sucht nun etwas Positives über die Chinesen zu sagen. Er bekennt, dass er die „Kings“ (die konfuzianischen Kanons, Herder 285) und Konfuzius verehre, aber auch dieser sei von der mongolischen Abkunft. Schließlich kam Herder auf positive Eigenschaften zu sprechen, von denen die Jesuiten berichtet hatten:

Immer bleibt dieser Nation der Ruhm ihres Fleißes, ihres sinnlichen Scharfsinns, ihrer feinen Künstlichkeit in tausend nützlichen Dingen. D as Porzellan und die Seide, Pulver und Blei, vielleicht auch den Kompaß, die Buchdruckerkunst, den Brückenbau und die Schiffskunst nebst vielen andern feinen Hantierungen und Künsten kannten sie, eher Europa solche kannte. (Herder 289)

Dann jedoch kam aber gleich die Einschränkung, nämlich „nur dass es ihnen fast in allen Künsten am geistigen Fortgange und am Triebe zur Verbesserung fehlet" (Herder 289). Er schloss sein China-Kapitel mit der Feststellung, die wieder auf die mongolische Herkunft hindeutet:

Taumelnd von tatarischem Stolz verachten sie den Kaufmann, der sein Land verläßt, und wechseln betrügliche Ware, gegen das, was ihnen das Sicherste dünket: sie nehmen sein Silber und geben ihm dafür Millionen Pfunde entkräftenden Tee zum Verderben Europas. (Herder 286)

Man kann sich fast den Kommentar nicht verkneifen, dass die Britische O stindienKompanie nur deshalb das O pium nach China zwangimportierte, um sich am entkräftenden chinesischen Tee zu rächen. Erst im Vergleich mit den Nachbarländern Chinas, nämlich „Kotschinchina, Tonking, Laos, Korea, die östliche Tatarei, Japan" (Herder 286-288), werden die Chinesen in positiverem Licht dargestellt.

Es war Herder kaum gelungen zwischen den beiden entgegengesetzten Urteilen über China zu vermitteln. D as von ihm geprägtes Bild der „einbalsamierten $\mathrm{Mu}$ mie" hatte noch eine größere und länger anhaltende Wirkung auf die Mit- und Nachwelt als Montesquieus Slogan „c'est le baton qui donc governe la China“. D ie Manchu-Eroberung Chinas im 17. Jahrhundert und die Fortsetzung der konfuzianischen Staats- und Moralphilosophie der neuen Dynastie verleitete europäische Philosophen dazu, Manchus und Mongolen in einen Topf zu werfen, was bei Voltaire dazu führte, dass er $\mathrm{G}$ enghis Khan zum Prinz der Manchus in L'orphelin de la Chine machte. $\mathrm{Zu}$ Herders Zeit kam noch ein anderes Ereignis hinzu. Im frühen 17. Jahrhundert zogen einige mongolische Stämme an die Wolga, ließen sich dort nieder und wurden Vasallen des Zaren. Sie wurden in Europa als Kalmücken, eine Bezeichnung mit pejorativem Unterton, bekannt. Unter Katharina der Großen 
verloren sie an Autonomie und mussten zudem immer mehr Reiterei an die russische Armee liefern, so dass sie sich unter der Führung des Ubaschi Khan entschieden, wieder ins alte Stammland zurückzuziehen. D er damalige D alai Lama gab dazu seinen Segen und wählte den Tag des Aufbruchs aus. Im Januar 1771 brachen am Ostufer der Wolga ungefähr zweihunderttausend Menschen, ohne die $\mathrm{Zu}$ stimmung des Zaristischen Reiches, dem der Exodus extrem unangenehm war, los. Unterwegs wurden zwei D rittel von ihnen gefangen genommen oder sie starben. Sie verloren auch ihre sämtlichen Herden. Im Sommer kamen sie endlich in der chinesischen $\mathrm{G}$ renzstadt Ili an, wo sie als heldenhafte Heimkehrer empfangen wurden. Diese Episode hinterließ einen bitteren Nachgeschmack in Europa, besonderes im östlichen Teil, woher Herder stammte. D ies erhellt teilweise die Ressentiments, die Herder gegen die Mongolen und die von ihnen abstammenden Chinesen hegte. Hinzu kam noch die Verbindung der chinesischen Schrift mit der der Ägypter, die ja in der $\mathrm{G}$ enesis die Bösen waren.

Es ist bekannt, dass Herder ein Jahr vor seinem Tod die ersten von ihm übertragenen 12 Kapitel des Buchs der gerechten Mitte, T schong Y ong genannt in seiner Zeitschrift A drastea publizierte. Im gleichen Jahr aber erschien auch seine Übersetzung des Teils über China von Montesquieus L'esprit des L oix unter der Überschrift „Von den Sinesen“. Herder blieb dabei, dass die chinesische Herrschaft keine Monarchie, sondern lediglich D espotie sei, d.h. die Herrschaft der Willkür mit Gewalt. Diese beiden Übersetzungen erhellen, dass seine zwiespältige Grundeinstellung China gegenüber bis zu seinem Tod beibehalten hat.

\section{Schluss}

Das 17. und das 18. Jahrhundert stellen die erste Hälfte der Begegnung zwischen Europa und China dar. Wenn wir etwas Neuem begegnen, versuchen wir in der Regel mit unserem bereits vorhandenen Wissen an das Neue heranzutreten, was nicht immer ausreicht. Dann beginnt die eigentliche Rezeption, die Aneignung des Fremden. Es ist ein langwieriger Prozess, weil wir immer nur kleine Teile „entfremden", bevor wir diese wirklich verstehen können. Auch dann bleibt das Verständnis eine Interpretation ohne G ewähr. D enn wir interpretieren nach unserem Gutdünken, das von unserer Tradition abhängt. D ie Tradition ist aber eine dynamische Entität. D ie Jesuiten interpretierten das China ihrer Zeit nach ihren Prämissen, die sich beispielsweise nicht nur von denen der zeitgenössischen Bettelorden unterschieden, sondern sie konnten auch nur zum Teil mit den chinesischen Ansichten übereinstimmen. Die Berichte wurden in Europa gelesen und wiederum interpretiert. Eine Interpretation bedeutet häufig, dass jeder begreift, was ihm einleuchtet, was ihm nützlich und vorteilhaft scheint. D as Verstandene und Angeeignete müsste nicht identisch mit dem G emeinten sein. Dazu kommt noch die Zeit, innerhalb derer sich Prämissen wandeln. Daher sehen wir die unterschiedlichen Interpretationen der Jesuiten und der späteren Rezipienten wie Leibniz, Wolff bis 
Herder. Aber Wandlung oder Entwicklung erfahren nicht nur die Rezipienten, sondern auch die Gegenstände der Rezeption, in unserem Fall die chinesischen Menschen und Sitten. Europa ändert sich, China ändert sich, die Selbst- und Fremdbilder der Chinesen und Europäer ändern sich. Es ist ein Wandlungsprozess ohne Ende.

\section{Literaturangaben}

Anson, G eorge (1780): A V oyage round the W orld in the years M D C CV L , I, II, II, IV . London: W. Strahan, J. Rivington and Sons.

D odds, Muriel (1929): L es Réats de V oyage. Sources de L 'E sprit des L oix de M ontesquieu. (Nachdruck G enf: Slatkine 1980).

Gatterer, Johann Gottlieb (1764): H andbuch der U niversaltheorie nach ihrem gesamten U mfang bis auf unsere Z eiten fortgesetzt. $G$ öttingen.

von Glasenapp, Helmut (1954): Kant und die Religionen des 0 stens. Kitzengen/ Main: Holzner-Verlag.

Herder, Johann G ottfried (1985): Ideen zur Philosophie der G eschichte der M enschheit. Mainz: Fourier Verlag.

Adrian Hsia (2008): Transformation of the Chinese D ragon: Perceptions and Projections. In: Heinz-D ieter Assmann et. Al. (Hg.): Perœeptions and Images of China. Baden-Baden: Nomos.

Kant, Immanuel (1998): W erk e. D armstadt: Wissenschaftliche Buchgesellschaft.

Lee, Eun-Jeung (2003): ,A nti-E uropa'. D ie G eschichte der Rezeption des Konfuzianismus und der k onfuzianischen $\mathrm{G}$ esellschaft seit der frühen A ufk lärung. Münster: Lit Verlag.

Meiners, Christoph (1790): Von den Variatäten und Abarten der Neger. In: $\mathrm{G}$ öttingisches H istorisches Magazin von C. Meiners und L. T. Spittler. Band VI, 625645.

Meiners, Christoph (1791): Zweyte Abhandlung über die Natur der Germanischen und übrigen Celtischen Völker. In: Göttingisches $\mathrm{H}$ istorisches Magazin von $C$. Meiners und L. T. Spittler. Band VIII, 67-124.

Meiners, Christoph (1793): $\mathrm{G}$ rundriß der $\mathrm{G}$ eschichte der M enschheit. 2. Auflage. Lemgo: Meyer.

de Mendoza, Juan G onzalez (1585): H istoria de las cosas más notables, ritos y costumbres, del gran reyno de la China, sabidas assi por los libros de los mesmos Chinas, como por relacion de Religiosos y otras personas ques an estado en el dicho reyno. Roma: Bartholome Grassi. (Eine deutsche Teilübersetzung, D ie N eue Beschreibung des Königreichs C hina, erschien 1589 in Frankfurt am Main.) 
Merkel, Franz Rudolf (1920): G. W. V. L eibniz und die China-Mission. E ine Untersuchung über die A nfänge der protestantischen Missionsbewegung. Leipzig: Missionswissenschaftliche Forschungen.

Purchas, Samuel (1906): Hakluytus Posthumus or Purchas his Pilgrims. Glasgow: MacLehose and Sons.

Schlözer, August Ludwig (1775): V orstellung seiner U niversaltheorie. Göttingen.

Schlözer, August Ludwig (1789): W eltgeschichte nach ihren $\mathrm{H}$ aupt/ Theilen im A ufzug und Z usammenhänge. 2. Theil. Göttingen.

Widmaier, Rita: „Leibniz' verborgene Botschaft in den Novissima Sinica“. In: Li Wenchao und Hans Poser (Hg.) (2000): D as Neueste über China: G. W. L eibnizens N ovissima Sina von 1697. Stuttgart: Steiner.

Widmaier, Rita (2008): Leibniz' metaphysisches Weltmodell interkulturell gelesen. Nordhausen: Traugott Bautz.

Wolff, Christian (1985): 0 ratio de Sinarum philosophia practica. Rede über die praktische Philosophie der Chinesen. Herausgegeben und übersetzt von M. Albrecht. Hamburg: F. Meiner. 


\title{
Europa wird neu vermessen oder: Eine Art Atlantis
}

\author{
Karl Schlögel
}

Die Karte Europas wird neu gezeichnet. Der Verlauf der Grenze, die ein halbes Jahrhundert lang den Kontinent in zwei Hälften gespalten hatte, ist an vielen Stellen schon nicht mehr recht zu erkennen. Jalta-Europa hat sich aufgelöst. Für viele, die im Schatten des Eisernen Vorhangs aufgewachsen sind, ist es noch immer wie ein Wunder. Ein Leben lang war ihnen der Zutritt zur nächsten Nachbarschaft verschlossen oder doch so sehr erschwert, dass eine Lust zum Reisen und Erkunden nicht aufkommen wollte. Aber jetzt steigt man in München ins Flugzeug und ist zwei Stunden später in Kiew. Von Nürnberg nach Prag, das war in der Hochzeit des Kalten Krieges keine Tagesfahrt, sondern ein bürokratisches Abenteuer. Heute pendeln Geschäftsleute und Arbeitnehmer über die Grenze, die keine mehr ist. Wien und Bratislava, um 1900 schon einmal durch eine Straßenbahn verbunden, waren einander nach dem Einmarsch der Truppen des Warschauer Paktes 1968 in weite Ferne gerückt. Nun wird an Plänen für eine Twin-City gearbeitet. Freilich rollte durch Berlin jahrzehntelang der Ost-West-Express von Paris nach Moskau, aber die Reise dauerte 30 Stunden, Visabeschaffung und Bewältigung der Hotelfrage nicht miteingerechnet. Heute gibt es Billigflüge, die das russische Publikum zum Shopping tagsüber ins $\mathrm{KaD}$ eWe und abends wieder nachhause bringen. Auf der 
anderen Seite der alten Grenze dürfte das Sichwundern über den radikalen Wandel noch stärker sein. Es war ja nicht nur schwierig, sondern ausgeschlossen - es sei denn man hatte das Pensionsalter erreicht oder gehörte zur speziellen Kategorie der "Reisekader" - die G renze zu überschreiten. Es war einfacher, von Leipzig auf die Krim als an den Bodensee zu fahren. Man fuhr leichter von O st-Berlin nach Ulan-Bator als nach West-Berlin. All das ist seit 1989 vorbei, auch wenn die Generationen, die noch die Grenzübergänge von Marienborn oder BerlinFriedrichstraße kennengelernt haben, bis ans Ende ihrer Tage diese Grenze im Kopf behalten werden.

Für die jetzt Jungen hat es diese $\mathrm{G}$ renze nie gegeben. Wer nach Prag oder Budapest fahren will, nimmt einen Bus oder einen Billigflieger. Wer seine Studien in Krakau fortsetzen möchte, bekommt die dazu nötigen Informationen am Auslandsamt seiner Universität und ein Stipendium dazu. Mit Interrail bewegt sich Europas Jugend, wenn sie es nur will, von einem Ende des Kontinents zum anderen - von Lissabon bis Tallinn, von Glasgow bis Budapest. Eine neue peregrinatio academica ist wieder in $\mathrm{G}$ ang gekommen, wie zuletzt wahrscheinlich in den Zeiten des vornationalen Europa im Zeitalter von Renaissance und Humanismus, als Studenten und Professoren ihre Karriere zwischen Prag und Salamanca, zwischen Sorbonne und Jagiellonen-Universität zurücklegten. Regionen kehren ins Bewusstsein zurück, von denen ein halbes Jahrhundert nicht mehr die Rede war, und die Namen von Städten und Orten, die man ein Menschenleben lang nicht mehr gehört hatte, werden wieder ausgesprochen. Wer hätte sich vorstellen können, dass es im Jahre 2005 eine Flugverbindung zwischen Frankfurt/ Main und Rzeszow, also zwischen dem Rhein-Main-G ebiet und dem alten Galizien geben würde! Und wer konnte sich ausmalen, dass man auf der Piazza Garibaldi in Neapel jeden Tag einen Bus mit Zielrichtung Kiew besteigen kann!

So entsteht nach und nach auch eine neue Karte im Kopf. Das zweigeteilte Europa bekommt plötzlich andere Konturen, mit neuen Peripherien und neuen Zentren. An die Stelle jenes monoton grauen Bilds vom „O stblock“ tritt die Konkurrenz ganz verschiedener G eschichts- und Kulturräume. Selbst der Name „O steuropa" erweist sich als ein ziemlich vager Sammelbegriff. Da gibt es mit einem Mal einen baltischen Raum, einen europäischen Nordosten mit Städten wie Lübeck, Stralsund, Danzig, Riga und Memel, denen unschwer anzusehen ist, dass sie älter sind als die Staaten, auf deren Territorien sie liegen. Die Silhouetten der Städte, die Bürgerhäuser an den Marktplätzen, die gotischen Dome und die virtuose Beherrschung des Backsteins als Material weisen sie als Stützpunkte der Hanse aus, eines Zusammenhangs also, dem auch der Ost-West-Konflikt letztlich nur wenig hatte anhaben können. Wir stoßen nicht nur auf Städte, die vom Krieg dem Erdboden gleichgemacht worden waren und wie durch ein Wunder zu neuem Leben erwacht sind - vielleicht am deutlichsten zu sehen in Boomtown Warschau -, sondern auf Städte, die - äußerlich wenigstens - unversehrt geblieben sind: Vilnius/ Wilna, Lwiw/ Lemberg, Czernowzy/ Cznernowitz. Wer aus diesen alten Metropolen, die sich einmal „Jerusalem des O stens" nannten oder „Klein-Wien“, in den 
alten Westen zurückkehrt, wird sich fragen, wie es hat kommen können, dass wir diese Zentren Europas auch nur für einen Augenblick haben vergessen können.

Zurück aus dem östlichen Europa erscheint einem die Bundesrepublik mit ihren nach dem Krieg wieder aufgebauten Städten wie ein gigantischer Neubau. Wir werden plötzlich einer durch die Teilung Europas erzeugten und tiefsitzenden Asymmetrie gewahr: wir kannten bis dahin die gotischen Kathedralen Deutschlands und Frankreichs, aber kaum die grandiosen Backstein-D ome des Baltikums. Uns sind die Stadtlandschaften O beritaliens oder Flanderns geläufig, aber von den Bürgerstädten und den Wehrkirchen Siebenbürgens haben wir nur selten gehört. Es bedurfte der Schreckensnachrichten der jugoslawischen Nachfolgekriege, um uns darauf hinzuweisen, dass es eine Stadtrepublik vom Format Ragusas/ D ubrovniks gab. Es bedurfte des Endes der Sowjetunion, um eine an die Peripherie und in die Provinzialität abgesunkene Hauptstadt des Russischen Reiches und eine Metropole der europäischen Moderne wie Sankt Petersburg wieder in unseren Horizont zurückzubringen. Fast immer sind es die Erschütterungen der Gegenwart, die am nachhaltigsten unser Bild verändern. Erst nach der O rangenen Revolution in Kiew verstanden wir, dass dort, hoch über dem D njepr, eine tausendjährige Stadt, die „Stadt der Städte" mit goldenen Türmen und K uppeln lag.

Aber wir sind vermutlich erst am Anfang einer großen Selbstentdeckung. Am Ende wird die Beschreibung Europas als eines ungemein reichen, vielfältigen Kontinents stehen, der nicht an der Elbe, nicht an der O der und auch nicht am Bug zu Ende ist. Das Europa der Parler, der Gotik, ist älter als das der heute existierenden Staaten. Das barocke Wilna ist Teil des großen Universums, dessen geheimes Zentrum Il Gesu in Rom ist. Eine Stadt wie Lodz ist ein Zentrum der europäischen Industrialisierungsgeschichte, eine Schwesterstadt von Manchester. Den Aufbruch in den Jugendstil können wir nicht nur in Brüssel oder Barcelona bestaunen, sondern in den Budapeser Bauten Ö dön von Lechners oder im Riga des Michail Eisenstein. Wir haben jahrzehntelang uns an den Schreckensorten des 20. Jahrhunderts umgesehen, nun dürfen wir uns auch auf den Schauplätzen eines glücklicheren Europa herumtreiben: auf dem D omplatz von Riga, auf dem wiedergewonnenen Pariser Platz, der unlängst noch Sperrzone gewesen ist, und wir flanieren über den Newskij Prospekt, der dabei ist, wieder zu einem Seismographen der Epoche zu werden.

Die mit 1989 verbundenen Veränderungen betrafen nicht nur Städte, sondern ganze Landschaften. Schlesien, die alte historische Landschaft, seit 1945 ein Hinterhof im Schatten der Oder-Neiße-Grenze, ist gleichsam in die Mitte Europas zurückgeglitten, während alte und wunderbare Städte, die ans Ende der Welt ge rutscht waren - man denke an G reifswald oder Görlitz - zu Durchgangsstationen in ein weiteres Europa geworden sind. Aber es geht nicht nur um den G ewinn, den man üblicherweise vom Sightseeing in schönen und alten Städten hat. Das wahrhaft Aufregende ist das Abenteuer der Zeit, zu sehen, wie Geschichte wieder in Fahrt gekommen ist, und zu lernen, wie weit Europa einmal schon gewesen ist in der Bewältigung des Schwierigsten: im Zusammenleben von Menschen verschie- 
denster Sprache, Kultur und Konfession auf engstem Raume. Es gab schon einmal ein Europa, G enerationen vor Erasmus-Stipendien und Bologna-Prozess, wo Vielsprachigkeit eine Lebensform und Arbeitsbedingung für Handwerker und Marktfrauen war, also nicht nur eine Eigenschaft gehobener Berufe und Stände. Und es gab schon einmal ein Europa, in dem die Koexistenz verschiedener Konfessionen zur G rundausstattung großer Städte gehört hatte - ein „Multikulturalismus“, von dem niemand ein Aufheben machte. Plurale Identitäten und Loyalitäten - gegenüber der Monarchie, dem Landesherren, der jeweiligen Stadt und G emeinde - war eine Errungenschaft nicht erst der Postmoderne mit ihren Diskursen über Identität, Alterität, Hybridität. Vieles, wozu Europa sich heute anschickt, scheint nichts weiter zu sein als die Wiederaufnahme einer 1914 abgebrochenen Arbeit.

Von jeder Reise in das erweiterte Europa bringen wir neue Bilder mit und arbeiten an der Wiederherstellung eines vollständigeren Bildes von Europa. Es ist fast unvermeidlich, und die nachdrücklichsten Lehrer bei diesem Vorgang sind nicht belehrende und aufklärende Texte, sondern die unmittelbare Anschauung selbst. Wo immer wir hinkommen, wir treten in Zusammenhänge ein, aus denen wir vorübergehend herausgefallen waren oder aus denen wir uns selbst verabschiedet hatten auf dem „langen Weg nach Westen“. Für niemanden gilt dies so sehr wie für die D eutschen, deren G eschichte über Jahrhunderte hinweg mit dem östlichen Europa aufs engste, fast unauflösbar verknüpft war. Wo immer die Deutschen im östlichen Europa unterwegs sind, sie treffen auf die Spuren deutscher Präsenz - und nicht nur jener katastrophischen, für die Wehrmacht, Einsatzkommandos, KZ, D eportationen und unsägliche Verbrechen stehen. Es gibt eine deutsche Präsenz, die älter ist und die auch durch das, was im 20. Jahrhundert geschah, nicht ungeschehen gemacht werden kann. Vielleicht könnte die Vergegenwärtigung dieser Spuren sogar das Interesse am anderen Europa vertiefen und zu einer Brücke in einen so lange vergessenen Kontinent werden. Die Wege in dieses uns abhanden gekommene Europa sind unendlich vielfältig und verschlungen. D as kann eine Reise nach Kaliningrad/ Königsberg sein, wo am D om nicht nur Kant begraben, sondern auch ein Kult wie nirgends anders zelebriert wird, oder ein Abstecher nach Friedrichstein, dem Gut der Dönhoffs, von dem nichts geblieben ist. Wir könnten Thomas Manns Sommerhaus auf dem Rücken der Kurischen Nehrung aufsuchen und dann mit dem Motorboot memelaufwärts nach Kaunas weiterfahren, das im Mittelalter auch Kauen geheißen hatte. Überall im östlichen Europa begegnet man älteren Reisenden auf der Suche nach den Spuren ihrer Kindheit oder ihrer Herkunft. D as können Schlesier sein, die längt in Köln leben, aber endlich die Reise zurück nach Schweidnitz, den Ort ihrer Kindheit und ihrer Flucht, gewagt haben. D as können die Kinder von Polen sein, die nach 1945 aus Lemberg umgesiedelt worden sind. Es können Überlebende des Holocaust sein oder deren Kinder, die die Reise aus Israel oder Amerika zurück in die alte Heimat, nach D rohobycz oder Mogilew unternommen haben. In den Jahrzehnten des Kalten Krieges war dies nicht möglich. 
Für die D eutschen, so ist mein Eindruck, steht die Wiederbegegnung und die Wiederaufnahme des Kontaktes mit dieser terra abscondita im $\mathrm{G}$ roßen und $\mathrm{G}$ anzen noch bevor. Wer schon in Mallorca war und sich dort auskennt, wird vielleicht den Zauber Marienbads oder der Thermen des G ellert-Hotels in Budapest entdecken. Wer in den schottischen Highlands unterwegs war, dem wird die transylvanische Hochebene mit Städten wie Klausenburg und Hermannstadt oder die wallachische Tiefebene noch eine Überraschung bereithalten. Und wer schon die Weiten Kanadas kennengelernt hat, dem hat auch die durch Eurasien führende Transsibirische Eisenbahn noch viel zu bieten. Es könnte sein, dass die größten Abenteuer in allernächster Nähe zu bestehen sind, und dass die größte Entdeckung dort zu machen ist, wo sie am wenigsten vermutet wird: in nächster Nachbarschaft. 



\title{
Interkulturelle Bildung - mehr als nur , andere Kulturen verstehen lernen'. Verstehen und Verständigung in interkulturell pädagogischer Perspektive
}

\author{
Yasemin Karakasoğlu
}

\section{Einleitung}

„Die theoretischen und praktischen Bemühungen Interkultureller Pädagogik kreisen um vier Fragenkomplexe und Motive, denen implizit und explizit die Annahme kultureller Differenz vorausliegt: a.) das Motiv der Fremdheit oder die Verstehensproblematik, b.) das Motiv der Anerkennung, das auf die Identitätsproblematik verweist, c.) das Engagement für Gleichheit, gegen D iskriminierung und Ausgrenzung auf Grund von Ethnisierung und Rassen-Konstrukten, d.) das Motiv interkultureller Verständigung in globaler Verantwortung." (Auernheimer 1998: 20)

Verstehen und Verständigung in kulturell heterogenen gesellschaftlichen Settings sind, darauf verweist dieses Zitat von G eorg Auernheimer, einem der Begründer der erziehungswissenschaftlichen Subdisziplin Interkulturelle Bildung, zentrale Fragenkomplexe dieses Faches. D er Rede vom Verstehen des ,Fremden' oder analog dazu ,anderer Kulturen' als einem Bestandteil interkultureller Kompetenz liegt ein spezifischer Kulturbegriff zugrunde. Auch wenn die Disziplin inzwischen selbstkritisch und reflektiert mit ihrem Schlüsselbegriff ,Kultur' umgeht und es ihr heute mehr um eine Dekonstruktion von Kultur als Erklärungsvariable für Konflikte zwischen Menschen geht, denn um Informationen über sogenannte Kulturkreise, so ist doch die öffentliche Wahrnehmung von Interkultureller Bildung do- 
miniert durch eine Vorstellung von interkultureller Kompetenz, die aus der Vermittlung spezifischer Kulturkenntnisse zur Lösung von Kulturkonflikten in pädagogischen Prozessen bestehe (vgl. Gültekin 2006). So wird beispielsweise bei Lehrerfortbildungen nicht selten gefordert, kompakte Kenntnisse über besonders fremde Kulturen zu vermitteln, die dann - so die Hoffnung der Teilnehmenden helfen sollen, das Handeln der Schüler, die als Repräsentanten dieser nationalen, ethnischen oder religiösen Kultur betrachtet werden, zu verstehen. Durch diesen Wunsch nach der Vermittlung von Kenntnissen über bestimmte Kulturen erfreuen sich z.B. Lehrerfortbildungen zum Islam, insbesondere aber zum G eschlechterverhältnis im Islam, größter Beliebtheit. Es wird erwartet, nach einer solchen Fortbildung pädagogisches Handwerkszeug in der Hand zu halten, das Lehrerinnen befähigt, etwa mit renitenten oder respektlosen männlichen Schülern aus dem so genannten ,islamischen Kulturkreis' umzugehen, deren Verhalten pauschal auf die angeblich grundsätzlich niedrigere Stellung von Frauen in muslimischen Gesellschaften zurückgeführt wird.

Auch die einschlägige ausländerpädagogische und interkulturelle Fachliteratur der 1970er bis 1990er Jahre ist durch das Paradigma dominiert, die Aneignung von Kulturkenntnissen könne zum Verstehen von Andersartigkeit und damit zur Überwindung von Fremdheit führen. D och ist damit die Zielsetzung aktueller Ansätze Interkultureller Bildung unzulässig verkürzt und damit nicht adäquat beschrieben, wie im Folgenden deutlich gemacht werden soll.

\section{Interkulturelle Bildung - von der affirmativen zur kritischen Auseinandersetzung mit ,Kultur'}

Nach vielfältigen Entwicklungen, die das Fach in den letzten dreißig Jahren durchlaufen hat, kann heute als innerdisziplinär konsensfähige Merkmalsbeschreibung Interkultureller Bildung gelten, dass diese Teil allgemeiner Bildung ist und zwar als Schlüsselqualifikation und Querschnittsaufgabe der Erziehungswissenschaft. Sie ist zugleich eine Entwicklungsaufgabe, die zum einen auf Veränderung von D eutungsmustern, Einstellungen und Haltungen bei allen an pädagogischen Prozessen Beteiligten abzielt. Zum anderen beabsichtigt sie aber auch eine Veränderung diskriminierender Strukturen im Bildungswesen, die sich an sprachlicher, kultureller, ethnischer und nationaler Homogenität als ,Normalfall' orientieren. Interkulturelle Bildung umfasst auch förderpädagogische Angebote z.B. für Kinder und Jugendliche mit Migrationshintergrund, denn diese haben den Sinn, den Adressaten Kompetenzen zu vermitteln, die sie für eine gleichberechtigte Teilhabe an Bildung brauchen. Aber vorrangig wenden sich Konzepte und Methoden Interkultureller Bildung generell an alle Lehrenden und Lemenden. In einer globalisierten Welt kommt Interkultureller Bildung die Aufgabe $\mathrm{zu}$, eine $\mathrm{O}$ rientierungshilfe $\mathrm{zu}$ bieten und Handlungskompetenzen zu vermitteln (Krüger-Potratz 2005). So oder so ähnlich formulieren es auch Gogolin und Krüger-Potratz (2006), Roth (2002) oder 
auch Nohl (2006) in ihren aktuellen Publikationen zur Einführung in die Interkulturelle Pädagogik.

D er Begriff ,Interkulturelle Pädagogik', wie er in D eutschland heute verwendet wird, ist gegenüber einem Verständnis von ,multikultureller Erziehung' abzugrenzen. Während diese als Regelung eines gleichberechtigten „Nebeneinanders' von Menschen verschiedener Herkunftskulturen zumeist in ausgewiesenen Einwanderungsländern mit dem Anspruch auf die besondere Berücksichtigung der je eigenen kulturellen (kollektiven) Identität von Zugewanderten vor allem in England, Nordamerika, Kanada und Australien auftritt (Sting 1997: 124-125), soll ,Interkulturelle Erziehung' im aktuellen deutschen Diskurs zu einem aktiven gesellschaftlichen Miteinander der Menschen verschiedener Herkunftskulturen führen, im Idealfall zur Akzeptanz einer neuen gemeinsamen kulturellen Basis. Dies Verständnis findet sich in der Definition des Begriffs durch Micheline Rey-von-Allmen (1984: 47) wieder: „Wer ,interkulturell’ sagt, der meint, indem er der Vorsilbe ,inter' ihre ganze Bedeutung gibt, notwendigerweise: Interaktion, Austausch, Entgrenzung, Gegenseitigkeit, objektive Solidarität; er meint auch, indem er dem Begriff ,Kultur' seine ganze Bedeutung gibt, Anerkennung der Werte, der Lebenswelten und ihrer Symbolleistungen, auf die sich Menschen, als Individuen und Gesellschaften gründen, in ihrer Beziehung zu anderen und in ihrer Wahrnehmung der Welt: er meint Anerkennung ihrer Bedeutsamkeit, ihrer Funktionsweisen, ihrer Verschiedenheit, Anerkennung zugleich der Wechselbeziehungen zwischen den vielfältigen Registern ein und derselben Kultur und zwischen den verschiedenen Kulturen."

Interkulturelle Pädagogik erhält damit die Aufgabe, ein Amalgam zwischen den verschiedenen Kulturen, Nationen und Religionen zu bilden und „die Chancen der Mitglieder einer G esellschaft zur demokratischen Teilnahme und Teilhabe" zu fördern (Dietzel-Papakyriakou 1997: 23). Hier schließt interkulturelle Pädagogik an Ideen einer Politik der Anerkennung an (Taylor 1992). Sie wendet sich also an Mehrheit und Minderheiten zugleich und setzt sich auch mit diesem Anspruch dezidiert gegenüber ihrem Vorläufer, der ,A usländerpädagogik', ab. D er Prozess einer Abkehr von ausländerpädagogischen und Hinwendung zu interkulturellen Konzepten unter Vertretern dieser pädagogischen Subdisziplin wurde nicht selten mit dem Begriff des ,Paradigmenwechsels' beschrieben (D ietzel-Papakyriakou 1997: 23). Kritisiert wurde das der Ausländerpädagogik zugrunde liegende statische Kulturkonzept, das der Annahme zugrunde lag, ausländische Kinder unterlägen in ihrem Sozialisationsprozess einem permanenten und unausweichlichen Kulturkonflikt zwischen der Kultur des Elternhauses und derjenigen der Schule bzw. umgebenden deutschen Gesellschaft (vgl. hierzu Schrader/ Nikles/ Griese 1976). Aber auch der Begriff der „Interkulturellen Pädagogik“ wird heute - u.a. auch von Wissenschaftlern und Wissenschaftlerinnen, die dieses G ebiet repräsentieren - wegen seiner Fixierung auf die Bedeutung kultureller Differenzen für die ungleichen Partizipationschancen von Zugewanderten an der Gesellschaft zunehmend kritisiert. Ihm wird - wie eingangs bereits angesprochen - vorgeworfen, mit der Formulierung „interkulturell“ kulturelle Differenzen als spezifische Verschiedenheit über- 
zubetonen bzw. mit einer solchen Fokussierung Differenz überhaupt erst herzustellen (Mecheril 2004: 15ff.).

Paul Mecheril schlägt als Ersatz „Migrationspädagogik“ vor: „Migrationspädagogik bezeichnet einen Blickwinkel, unter dem Fragen gestellt und thematisiert werden, die bedeutsam sind für eine Pädagogik unter den Bedingungen einer Migrationsgesellschaft“ (ebenda: 18). „'Migration' ist eine Perspektive, die von vornherein anzeigt, dass die Einengung auf eine kulturelle Betrachtung der mit Wanderung verbundenen Phänomene unangemessen ist." (ebenda). D urchgesetzt hat sich diese Begrifflichkeit jedoch bislang nicht.

D ie Zentralität des Kulturbegriffs ist sowohl Merkmal Interkultureller Bildung wie auch Problem. Hier zeigt sich eine gewisse Kontinuität zur Ausländerpädagogik. Während ausländerpädagogische Konzepte in kultureller Andersartigkeit, kulturellen Unterschieden - zumeist zugespitzt auf kulturelle Traditionspflege und sprachliche D istanz zum Aufnahmeland die Kulturen der Zuwanderer als defizitär und daher eher hinderlich für die Eingliederung in die Aufnahmegesellschaft betrachtet hat, konzentriert sich Interkulturelle Bildung stark auf den Aspekt der Kultur als (positiv zu nutzendes) Unterscheidungskriterium (vgl. Boos-Nünning 1997: 24). D er vom begegnungsorientierten Ansatz geforderte Kulturrelativismus erweist sich im konkreten pädagogischen Handeln als nicht durchhaltbar, da er in Konfliktsituationen zu Handlungsunfähigkeit der Beteiligten führen könne, die über keine gemeinsame Handlungsbasis verfügten (Nieke 2008: 85). D arüber hinaus birgt der auf den Aspekt der Kultur fokussierte Blick zum einen das Risiko, dass Probleme zwischen Mehrheit und Minderheit auf kulturelle Unterschiede reduziert, gesellschaftliche und politische Ursachen ausgeblendet werden. Zum anderen beinhaltet der kulturalistische Blick ein statisches Kulturverständnis, das Personen zu sehr auf ihre kulturelle Herkunft, diese wiederum auf ihre ,Ursprünglichkeit' festlegt. Dies kommt zum Beispiel in der ethnische und religiöse Vielfalt missachtenden Rede von ,der türkischen Kultur' zum Ausdruck (vgl. Auernheimer 1995: 167; Nestvogel 1990: 31). In diesem Zusammenhang wird auch Kritik an der Folklorisierung der Migrantenkulturen laut (Diehm/ Radtke 1999: 132).

Sting erkennt in Ansätzen der interkulturellen Pädagogik eine als negativ zu bewertende „Verstrickung von Konzepten Interkultureller Erziehung mit der klassischen deutschen Bildungstradition“ (Sting 1997: 123), die sich in einer „Betonung der ,Kultur' für den Wert des Menschen“ sowie der „Bedeutung der „Erziehung” für die Hervorbringung dieser Kultur" äußere (126). Im spezifisch deutschen Zusammenhang, der sich auf Herder und Fichte zurückführen lässt, konstituiere sich der ,Charakter einer Nation', ihr ,inneres Wesen' in ihrer jeweiligen ,Nationalkultur', die es durch Erziehung und Bildung herauszubilden gelte (130-131). Dies sei einer der Gründe dafür, dass Differenzen zwischen Angehörigen verschiedener Nationen in multikulturellen $G$ esellschaften im deutschen D iskurs oftmals mit D ifferenzen zwischen den Kulturen erklärt würden. Die sich hinter Differenzen verbergenden ökonomischen, Generations- oder Kommunikationskonflikte träten daher hinter dem Erklärungsaspekt ,Kultur' vielfach zurück. Sting plädiert daher 
für eine intensive Auseinandersetzung mit den eigenen nationalen Prämissen, er nennt ein „reflexives Nationalbewußtsein“ als „unabdingbare Voraussetzung“ für ein "nicht vereinnahmendes Verhältnis zum Fremden und Andersartigen“ (140; vgl. hierzu auch Nestvogel 1990 und 1994).

Andere interkulturelle Pädagogen und Pädagoginnen setzten sich für ein verändertes Verständnis von ,Kultur' ein. Kultur als kollektives D eutungsmuster einer Lebenswelt präge zwar den Alltag und die Lebenslage von Menschen ganz wesentlich mit, dürfe jedoch nicht gleichgesetzt werden mit der Identität von Menschen (Nieke 2008: 37ff.). So wird es zwar als sinnvoll erachtet, Kulturen eingewanderter Minoritäten in ihrer strukturellen Andersartigkeit von der jeweiligen Herkunftskultur zu betrachten, dabei dürfe der Blick jedoch nicht verlorengehen für die strukturellen Ähnlichkeiten zu anderen Teilkulturen der Aufnahmegesellschaft. G ewarnt wird daher auch vor einer G leichsetzung von ,Kultur' und ,G esellschaft', die eine kritische Haltung gegenüber der G esellschaft durch Aneignung von Kultur - eine Forderung von Bildung in demokratisch verfassten Gesellschaften - unmöglich mache (Apitzsch 1997: 257). Voraussetzung für die Realisierung dieser Position ist ein Verständnis von Gesellschaft, die nicht mehr durch den Glauben an eine gemeinsame (nationale) Kultur und die in ihr eingebetteten Werte und Normen verbunden ist, sondern durch Verfassungspatriotismus (Boos-Nünning 1997: 27). An diesem Punkt wird die deutlich politische Komponente der Forderungen aktueller interkultureller pädagogischer Ansätze deutlich, die nicht selten in konkreten Forderungen an ein Handeln münden, „das aktiv gleiche Rechte für alle anstrebt und Diskriminierungen, wie sie z.B. in dem bundesdeutschen Ausländergesetz festgeschrieben sind, energisch entgegentritt" (Nestvogel 1990: 32).

Als Ausweg aus dem Dilemma, mit der Selbstbezeichnung „interkulturell“ kulturelle Zuschreibungen festzulegen, schlägt Wolfgang Welsch (1992) das Konzept der „transkulturellen Pädagogik“ vor. Als wesentliches Kennzeichen von Transkulturalität benennt Welsch auf der Makroebene die externe Vernetzung der Kulturen und die Hybridisierung, auf der Mikroebene die transkulturelle Prägung der Individuen durch verschiedenartige, je individuelle kulturelle Herkünfte und Bindungen. Transkulturelle Gesellschaften seien nicht mehr einheitlich und monokulturell bestimmt, sondern umfassten eine Vielfalt unterschiedlicher (Teil-) Kulturen. Die erworbene Kultiviertheit der Individuen sei nicht mehr durch eine einheitliche, homogene Kultur geprägt, sondern durch die verschiedenen Kulturen, die Einfluss auf den je individuellen Sozialisationsprozess hätten. Voraussetzung dafür sei die Betrachtung des einzelnen Subjekts als eines, das an verschiedenen Wissens- und Symbolsystemen oder gesellschaftlichen Praxen partizipiert. Multikulturalität sei dann nicht mehr die Anwesenheit verschiedener Kulturen in einer Gesellschaft sondern eine Konstellation, in der die einzelnen Gesellschaftsmitglieder gleichzeitig an verschiedenen Kulturen teilhaben oder sie als O rientierung nutzen können (vgl. hierzu auch Bhabha 2007, Datta 2005). Als Bezeichnung hat sich jedoch „Transkulturelle Pädagogik“ bislang nicht gegenüber „Interkultureller Pädagogik“ durchsetzen können. 
Hormel/ Scherr (2004) hingegen plädieren durchaus für die Beibehaltung des Begriffs interkulturelle Pädagogik, allerdings unter Zusatz des Attributs „reflektiert“, um deutlich zu machen, dass sich die Disziplin selbstkritisch mit ihrem Kulturbegriff auseinander setzt: „Eine reflek tierte interk ulturelle Pädagogik weist darauf hin, dass kulturelle Differenzen weder notwendig Ursache von Problemen und Konflikten noch allein als ein Effekt sozialer Ungleichheiten verständlich sind. Sie bricht mit der Prämisse eines naiven Kulturalismus, der zufolge Individuen Angehörige einer Kultur und durch diese geprägt sind. Sie fordert zur Auseinandersetzung mit den Bedingungen, Formen und Folgen von ethnischen, kulturellen und religiösen $\mathrm{Zu}-$ schreibungen und Identifikationen sowie ihrer gesellschaftspolitischen, sozialen und individuellen Bedeutung auf." (Hormel/ Scherr 2004: 15)

\section{Verstehensbemühungen in der Gefahr der kulturalistischen Ver- einnahmung}

G rundsätzlich können nach Hohmann zwei Hauptansätze hinsichtlich der Methoden und Zielsetzung Interkultureller Erziehung unterschieden werden. Es handelt sich um den begegnungs- und um den konfliktorientierten Ansatz (Hohmann 1983, Nieke 2008: 34f.). In ihrer Fokussierung auf die Pädagogik der Begegnung fordert Interkulturelle Erziehung die Zurkenntnisnahme der Differenzen zwischen zugewanderten Kulturen und der Kultur der Aufnahmegesellschaft, die Förderung gegenseitiger Information, die Repräsentation der fremden Kulturen im öffentlichen Leben für die Majorität und die Betonung der gegenseitigen kulturellen Bereicherung durch interkulturelle Kontakte. Dieser Ansatz wird vereinzelt auch als ,Pädagogik der kulturellen D ifferenz' bezeichnet (Leiprecht 1999: 2). Er findet sich wieder in Konzepten interkultureller Jugendarbeit, z.B. in der internationalen Jugendbegegnung sowie der Eine-Welt-Erziehung oder Globalem Lernen.

In ihrem konfliktorientierten Ansatz fordert Interkulturelle Pädagogik in erster Linie die Bekämpfung von $\mathrm{G}$ rundlagen gesellschaftlicher Ungleichbehandlung, die sich in Ausländerfeindlichkeit, D iskriminierung und Rassismus äußern. Hier wurden Impulse des angelsächsischen Antirassismus-D iskurses aufgenommen. Pädagogen sollen sich aktiv für die Beseitigung von Formen institutioneller Diskriminierung und sozialstruktureller Marginalisierung einsetzen (ebenda). Ziel ist die Herstellung von Chancengleichheit für Minderheiten und Mehrheit. Auf diesen Ansatz berufen sich Konzepte der Antirassismus-Erziehung, des Interkulturellen Konfliktmanagements und der Politischen Jugend- und Erwachsenenbildung.

D ie meisten Konzepte interkultureller Bildung verbinden heute Elemente beider Ansätze miteinander. So wird im Allgemeinen ein Bewusstsein für die politisch ge-stützte D ominanz der Mehrheitskultur (vgl. ,D ominanzkultur' bei Rommelspacher 1995) und eine kritisch-konstruktive Auseinandersetzung mit ,Fremdheitserfah-rungen' über die „Suche nach dem Eigenen im Fremden und nach dem Fremden im Eigenen" (Nestvogel 1994: 37, Holzbrecher 2004: 90f.) gefordert. 
Vertreter und Vertreterinnen dieser Linie warnen gleichzeitig vor möglichen $\mathrm{Ge}$ fahren auf diesem Weg. So könne es über die Entdeckung des, Eigenen im Fremden' zu einer möglichen Vereinnahmung und Bemächtigung des Fremden/der Fremden kommen. In diesem Sinne können „Verstehensbemühungen ... als Versuche verstanden werden, die Ambivalenz des Fremden aufzulösen, also eine Entscheidung darüber herbeizuführen, ob es integriert oder abgespalten/ bekämpft werden soll" (Scherr 1998: 55). Verstehen des Fremden war und ist daher historisch und aktuell nicht immer ein Vorgang wechselseitiger Verständigung unter Gleichen sondern teilweise verbunden mit dem Wunsch, Macht, Kontrolle und Herrschaft über die Minderheit(en) auszuüben (Kolonialpädagogik). D ort, wo eindeutige Klassifikationen nicht möglich erscheinen und der Umgang mit Mehrdeutigkeiten und Ambivalenzen nicht gelernt wurde oder unerwünscht ist, kann es schließlich zu Ausgrenzungsprozessen kommen. Diese Prozesse begünstigten die Entstehung eines „kulturalistischen Rassismus" (Nestvogel 1994: 44), der weniger auf tatsächlicher Fremdheit als vielmehr der Zuschreibung von Fremdheit beruhe, womit eine benachteiligte soziale Position, des/ der Fremden' legitimiert werden solle. Die pädagogische Zielsetzung des ,Verstehens' lässt sich am ehesten mit dem begegnungspädagogischen Ansatz verbinden, Verständigung jedoch geht darüber hinaus. Sie setzt eine Begegnung auf Augenhöhe und eine durchaus auch konflikthafte, jedoch friedliche Auseinandersetzung über den $\mathrm{G}$ egenstand voraus und kann daher eher dem konfliktpädagogischen Ansatz zugeordnet werden. D as Konzept der diskursiven Verständigung in interkulturellen Begegnungen, das vor allem als konstruktiver Vorschlag für die Lösung konflikthafter Situationen betrachtet werden kann, sucht nach einem Ausweg aus dem Dilemma der Anerkennung von (kultureller) D ifferenz und der ungleichen gesellschaftlichen Machtverhältnisse. Im Vordergrund der aktuellen interkulturellen Ansätze, die sich stärker am konfliktpädagogischen Ansatz orientieren, steht daher weder die Überbetonung noch die Harmonisierung oder Idealisierung von Unterschieden zwischen Menschen oder Kulturen sondern die Befähigung der Beteiligten, (auch aber nicht ausschließlich) kulturell konnotierte Konflikte aushalten und konstruktiv mit ihnen umgehen zu können - d. h. sich mit der Konfliktpartei über eine Lösung zu verständigen.

\section{Diskursive Vermittlung in interkulturellen Konflikten - Verstän- digung auf Augenhöhe}

Bei Nieke (2008: 244ff.) soll der Umgang mit kulturell konnotierten Konflikten, deren Existenz als selbstverständlich in interkulturellen Begegnungen betrachtet wird, mittels eines Diskurses in sieben idealtypischen Schritten (Sieben-SchritteDiskurs) vermittelt werden. Am letzten Schritt in diesem D iskurs betrachtet Nieke die Vermittlung des Prinzips der situativen Geltung von Normen, die verhandelt werden sollen, auf der Basis eines diskursethischen Ansatzes. D amit wird der Erfahrung Rechnung getragen, dass sich beide Grundpositionen Interkultureller Pä- 
dagogik gleichermaßen an pädagogischen und gesellschaftlichen Utopien orientieren, zu wenig Erfahrungen aus der Praxis aufgriffen haben und sich daher vielfach als praktisch nicht umsetzbar erwiesen.

Nach Peter L. Berger (1997) können grundsätzlich drei Typen von Vermittlung hinsichtlich der Verständigung über die Geltung von Normen in pluralistischen G esellschaften unterschieden werden: die ,imperative', ,pragmatische' und ,dialogische Vermittlung'. Bei der ,imperativen V ermittlung' handelt es sich um einen Vermittlungsprozess, der durch eine politische oder rechtliche Agentur erfolgt mit dem Ziel, eine klare Entscheidung zu treffen, die dann gegenüber den beteiligten Parteien als diese bindend durchgesetzt wird (Berger 1997: 602-604). Die Zustimmung aller Betroffenen wird letztlich unter Androhung von Sanktionen, im Normalfall durch Rechtsgewalt erzwungen. Die ,pragmatische V ermittlung' bezeichnet einen Prozess zwangsfreier Verhandlung, in dem die Parteien selbst nach Kompromisslösungen suchen. Ziel ist es hierbei, normative Meinungsverschiedenheiten $\mathrm{zu}$ übergehen, die Grundpositionen aller Beteiligten festzulegen und schließlich einen pragmatischen Kompromiss auszuarbeiten. Normen, so Berger, werden im Zuge dieses Prozesses in Interessen übersetzt (ebenda: 604-606). Ist ein Kompromiss gefunden, einigen sich die Beteiligten auf den Verzicht auf weitere öffentliche Auseinandersetzungen in dieser Frage. Dieser Ansatz entspricht dem von Nieke vorgeschlagenen pragmatischen Prinzip der situativen G eltung von Normen. Im G egensatz zur imperativen Vermittlung wird hier der Konflikt ohne Rückgriff auf Zwangsmaßnahmen gelöst. Allerdings scheint dieses Verfahren nicht durchführbar, wenn es um „tief verwurzelte Normen“ geht, die zur Disposition gestellt werden müssten, jedoch von den Parteien als nicht verhandelbar betrachtet werden. D ieser Vermittlungsart sind damit in der Praxis G renzen gesetzt. D ie dem diskursethischen Ansatz verpflichtete ,dialogische V ermittlung' nach Berger schließlich will normative Unterschiede direkt aufgreifen und nicht nur nach einem pragmatischen, sondern (neue) Ideen bildenden Kompromiss suchen. Voraussetzung hierfür ist, dass die an dieser Form der Vermittlung beteiligten Menschen bereit sind, ihre Überzeugungen und Werte einer Vernunft geleiteten D iskussion unterzuordnen. Denn diese setzt eine echte Auseinandersetzung mit der Andersartigkeit der verschiedenen Konfliktparteien voraus, anstatt einfach nur nach dem kleinsten gemeinsamen Nenner zu suchen (ebenda: 606-608). Ziel ist es, die Parteien zu der Erkenntnis zu bringen, dass die jeweilige ,G egen'-Partei ebenso legitime Identitätsund Existenzansprüche vorbringt wie sie selbst. Bergers Klassifikation beinhaltet eine deutliche qualitative Steigerung von der imperativen zur dialogischen Vermittlungsform. Einzig ein auf der Basis der Gleichwertigkeit aller Verhandlungspartner und- partnerinnen basierendes, gemeinsames Aushandeln von Notwendigem und Tolerierbarem bietet die Chance einen gesamtgesellschaftlichen Konsens hervorzubringen, der von einer Mehrheit getragen werden kann.

Mit ihrem ,Vier-Punkte-Programm' zielt Boos-Nünning darauf ab, Rahmenbedingen für interkulturelle Verständigungsprozesse abzustecken, die sich gegen die Tendenzen innerhalb der interkulturellen Pädagogik wenden, Migranten und 
Migrantinnen die Position von selbstbestimmten Individuen zu bestreiten, die sich nach ihren eigenen Vorstellungen mit kulturellen oder religiösen Traditionen, Werten und Normen auseinandersetzen. Sie bezeichnet Bildungsaktivitäten, Konzepte oder Programme nur dann als interkulturell, wenn sie sich an Einheimische wie Zugewanderte in gleicher Weise richten, wenn sie Migranten nicht als problematischen Faktor für die Entwicklung eines Landes vermitteln, sondern die Ressourcen der Zuwanderer in den Mittelpunkt stellen, wenn sie nicht die einseitige Anpassung der Zugewanderten an das Wert- und Normsystem der Aufnahmegesellschaft fordern, sondern ein Aushandeln zulassen und wenn sie nicht die Kulturen der Herkunftsländer, sondern die lebendigen Kulturen der Migrantenpopulationen in Deutschland in den Bildungs- und Sozialisationsprozeß der ausländischen wie deutschen Kinder einbeziehen (Boos-Nünning 1997: 19). Hinzuzufügen wäre, in Anlehnung an Nieke, dass Bildungsaktivitäten, Programme und Konzepte zukünftig nur dann das Prädikat ,interkulturell' verdienen, wenn „,bei der Konzeptualisierung von Interkultureller Erziehung genauer und empirischer als bisher die Perspektive der Betroffenen" ermittelt und berücksichtigt wurde. D as heißt konkret, wenn an der Entwicklung von interkulturellen pädagogischen Ansätzen Angehörige der Mehrheit wie auch der Minderheiten gleichberechtigt beteiligt werden (Nieke 2008: 73).

\section{Ausblick}

Auch wenn in der Praxis Interkulturelle Bildung noch weit davon entfernt ist, als durchgängiges Bildungs- und Erziehungsprinzip verbreitet und in entsprechenden Konzeptionen fest verankert zu sein, so hat die von vielen interkulturellen Pädagogen und Pädagoginnen vorgebrachte Forderung nach einer interkulturellen Bildung als konstitutivem Element der Allgemeinbildung und Q uerschnittsdimension der Erziehungswissenschaft mittlerweile auf der Ebene aktueller pädagogischer Diskurse und bildungspolitischer Beschlüsse durchaus Beachtung und Umsetzung gefunden (Gogolin/ Krüger-Potratz 2006: 135f.). Interkulturelle Konzepte und der Erwerb interkultureller Kompetenzen ist zumindest theoretisch in den Kanon der geforderten ,Schlüsselqualifikationen' von Lehrenden und Lernenden integriert worden, der vor allem im Rahmen von Schule vermittelt werden soll (vgl. KMKEmpfehlungen zum Interkulturellen Lernen in der Schule aus dem Jahr 1996) und die Auseinandersetzung mit Fragen von Migration und Integration ist inzwischen integraler Bestandteil von Schulleistungsstudien und nationaler Bildungsberichterstattung. Mit der Bedeutungszunahme der Thematiken Migration und Integration in der aktuellen politischen D ebatte über die Ausgestaltung und Zukunft der $\mathrm{Ge}$ sellschaft gewinnt auch die Interkulturelle Bildung als D isziplin, der von bildungspolitischer Seite die Aufgabe zugeschrieben wird, die Integration von zugewanderten Minderheiten in die Gesellschaft zu befördern und an einer Umgestaltung des Bildungssystems sowie neuer Bildungskonzeptionen mitzuwirken, zunehmend an 
Relevanz. Kaum jedoch werden bislang die hier geschilderten Impulse des Faches zur Auseinandersetzung mit dem Paradigma kultureller Differenz und zur Verständigung in interkulturellen Bildungsprozessen aufgegriffen.

\section{Literaturangaben}

Apitzsch, Ursula (1997): „Interkulturelle Arbeit: Migranten, Einwanderungsgesellschaft, Interkulturelle Pädagogik“. In: Krüger, Heinz-Hermann/ Rauschenbach, Thomas (Hrsg.): E infuhrung in die A rbeitsfelder der E rziehungswissenschaft, 2. durchgesehene Auflage. O pladen: Leske + Budrich, 251-268.

Auernheimer, Georg (1998): Grundmotive und Arbeitsfelder interkultureller Bildung und Erziehung. In: Bundeszentrale für politische Bildung (Hrsg.): Interk ulturelles L ernen, A rbeitshilfen für die politische Bildung. Bonn, 18-28.

Auernheimer, Georg (1995): E infuhrung in die Interkulturelle Erziehung. 2. überarbeitete und ergänzte Ausgabe. Darmstadt: wissenschaftliche Buchgesellschaft.

Berger, Peter L. (Hrsg.) (1997): D ie G renzen der G esellschaft. Konflikt und V ermittlung in pluralistischen $\mathrm{G}$ esellschaften. Gütersloh: Verl. Bertelsmann-Stiftung.

Bhabha, Homi K. (2007): D ie V erortung der Kulturen. Studien zur Inter- und Multikultur Band 5. Tübingen: Stauffenburg.

Boos-Nünning, Ursula (1997): „O ffene theoretische Probleme des interkulturellen Bildungsgedankens". In: Rickert, Folkert/ Gottwald, Eckhart (Hrsg.): V erständigung und religiöse V ielfalt. D uisburg, 19-29.

D atta, A sit (Hrsg.) (2005): Transk ulturalität und Identität. Frankfurt: IKO-Verlag.

Diehm, Isabell/ Radtke, Frank-Olaf (1999): E rziehung und Migration. E ine E inführung. Stuttgart, Berlin, Köln: Kohlhammer.

Dietzel-Papakyriakou, Maria (1997): ,D ie alltägliche Suche nach dem Verborgenen. Die Pädagogik zwischen Kulturrelativismus und Universalismus". In: E ssener U nikate 9/ 1997, 23-27.

Gogolin, Ingrid/ Krüger-Potratz, Marianne (2006): E inführung in die Interk ultu-relle Pädagogik. O pladen:Verlag Barbara Budrich.

G ültekin, N. (2006): Interkulturelle Kompetenz: Kompetenter professioneller Umgang mit sozialer und kultureller Vielfalt. In: Lieprecht, R./ Kerber, A. (Hrsg.): Schule in der E inwanderungsgesellschaft. Schwalbach/Ts.: Wochenschau-Verlag, 367-386.

Hohmann, Manfred (1983): Interkulturelle Erziehung - Versuch einer Bestandsaufnahme. In: A usländerk inder in Schule und Kindergarten, 4. Jg., 2-8. 
Holzbrecher, Alfred (2004): Interk ulturelle Pädagogik . Berlin: Cornelsen Verlag.

Hormel Ulrike/ Scherr, Albert (2004): Bildung für die E inwanderungsgesellschaft. Perspek tiven der A useinandersetzung mit struk tureller, institutioneller und interak tioneller D isk riminierung. Wiesbaden: VS V erlag für Sozialwissen-schaften.

Krüger-Potratz, Marianne (2004): Ist die Interkulturelle Pädagogik in der Erziehungswissenschaft „angekommen“? In: Karakaşoğlu, Yasemin/ Lüddecke, Julian (Hrsg.): Migrationsforschung und Interkulturelle Pädagogik. Münster: Waxmann-Verlag, 75-90.

Krüger-Potratz, M. (2005): Interkulturelle Bildung. E ine E inführung. Münster: Waxmann-Verlag.

Leiprecht, Rudolf (1999): „Interkulturelle und Antirassistische Pädagogik“. In: A rbeitshilfen zum Jugendschutz, Nr.3/ 35. Jg., September 1999, 1-8.

Mecheril, Paul (2004): M igrationspädagogik. Weinheim, Basel: Beltz-Verlag.

Nestvogel, Renate (1990): „Interkulturelles Lernen. Ein Beitrag zum Abbau von Fremdenfeindlichkeit und Ethnozentrismus?". In: ZEP, 13. Jg. Heft 3, O ktober 1990, 30-33.

Nestvogel, Renate (1994): „'Fremdes' oder ,Eigenes'? Freiräume zwischen A usgrenzung und Vereinnahmung“. In: Nestvogel, Renate (Hrsg.): „Fremdes“ oder "E igenes". Rassismus, A ntisemitismus, Kolonialismus aus Frauensicht. Frankfurt am Main: IKO , 27-69.

Nestvogel, Renate (2006): Bildungs- und Berufserfahrungen von afrikanischen Migrantinnen in D eutschland. In: Schlüter, Anne (Hg.): Bildungs- und Karrierewege von Frauen. Opladen: Budrich, 145-167.

Nieke, Wolfgang (2008): Interk ulturelle E rziehung und Bildung. W ertorientierungen im A lltag. Wiesbaden: VS Verlag für Sozialwissenschaften. 3., aktualisierte Aufl.

Nohl, Amd-Michael (2006): Konzepte interkultureller Pädagogik. Bad Heilbrunn: Verlag K linkhardt.

Rey-von-Allmen, Micheline (1984): Interkulturalismus - Holzwege und Herausforderungen. In: Reich, Hans H./ Wittek, Fritz (Hrsg.): Migration - Bildungspolitik - Pädagogik. Berichte und Materialien der Forschungsgruppe ALFA Nr. 16. Essen/ Landau.

Rommelspacher, Birgit (1995): D ominanzkultur. Texte zur Fremdheit. Berlin: Orlanda-Verlag.

Roth, Hans-Joachim (2002): Kultur und Kommunikation. Systematische und theoretische U mrisse von Interk ultureller Pädagogik. O pladen: Leske + Budrich. 
Scherr, Albert (1998): „D ie Konstruktion von Fremdheit in sozialen Prozessen. Überlegungen zur Kritik und Weiterentwicklung Interkultureller Pädagogik“. In: N eue Prax is 28. Jg., 1998/ Heft 1, 49-57.

Schrader, Achim/ Nikles, Bruno W./ Griese, Hartmut M. (1976): D ie Zweite $\mathrm{G}$ eneration. Sozialisation und A kkulturation ausländischer Kinder in der Bundesrepublik. Kronberg: Athenäum.

Sting, Stephan (1995): „Interkulturelle Erziehung in der ,Deutschen Kulturnation'“. In: Hildebrand, Bodo/ Sting, Stephan (Hrsg.): E rziehung und kultu-relle Identität. Beiträge zur D ifferenz pädagogischer Traditionen und Konzepte in E uropa. Münster, New York: Waxmann, 121-143.

Taylor, Charles (1992): Multikulturalismus und die Politik der A nerk ennung. Frankfurt am Main: Suhrkamp Verlag.

Welsch, Wolfgang (1992): Transkulturalität. Lebensformen nach der Auflösung der Kulturen. In: Information Philosophie, Mai 2, 5-20. 


\title{
Die Welt in Deutschland
}

\author{
Bernd Scherer
}

Als ich vor zwei Jahren meine Arbeit am Haus der Kulturen der Welt begann, machte mir der chinesische Kurator Hou Hanru den Vorschlag, den Namen des Hauses in der Schublade der G eschichte verschwinden zu lassen. Seine Argumente lauteten:

- Das Wort Haus ist im G egensatz zu dem Terminus „Museum“ viel zu allgemein.

- Auch das Wort „Kultur“ ist eigentlich nichtssagend im Vergleich mit dem der „Kunst".

- Gegen „die Welt“ schien Hou Hanru nichts einwenden zu wollen.

Nachdem ich über seine These nachgedacht hatte, erwiderte ich ihm, dass ich mich in den letzten Monaten auch mit dem Namen beschäftigt hätte, dass er mir nun aber genau die Argumente geliefert habe, die für seine Beibehaltung sprechen.

Warum? Zwar hat sich die Rolle des Museums im westlichen Kontext bereits seit den sechziger Jahren des vergangenen Jahrhunderts geändert. D ie Auseinandersetzung mit nichteuropäischen Kulturen stellt es aber vor weitere Herausforderungen. Die Aufgabe des klassischen Museums bestand in der Festlegung eines Kanons. Die in ihm gezeigten $\mathrm{G}$ egenstände definierten eine bestimmte Kunstrichtung bzw. eine historische Epoche. D ie räumliche Abfolge bestimmte die zeitliche D imension, in der sich die G eschichte der Kunst entfaltet hat. Mit der Präsentation in einem „White Cube“ und damit dem bewussten Verzicht auf jede Kontextualisierung verband sich der Anspruch auf eine universelle G eltung der inszenierten Repräsentation. 
In der Auseinandersetzung mit der nichtwestlichen Welt werden die Prämissen, in dieser Form G eschichte zu schreiben, noch einmal gründlich erschüttert. Da, wie schon ausgeführt, Geschichte aus der Gegenwart heraus geschrieben wird, erscheint es sinnvoll, ein Beispiel aus der zeitgenössischen Beschäftigung mit anderen $\mathrm{G}$ esellschaften zu analysieren, um erste zentrale $\mathrm{G}$ esichtspunkte zu gewinnen. Ich möchte deshalb im Folgenden auf das Projekt „RE ASIA“ des Hauses der Kulturen der Welt eingehen.

Asien erscheint zurzeit als der ökonomisch dynamischste Kontinent, mit seinen Großstaaten Indien und China an der Spitze, aber auch mit Ländern wie Japan, Korea, Vietnam u.a. Diese Entwicklung betrifft nicht nur Asien selbst, sondern Asien verändert auch den Rest der Welt. In New-D elhis Call-Zentren beraten Inder Kunden in Berlin. Die britische Sportwagenmarke MG wird seit dem 27.03.2007 in Nanjung hergestellt. China plant allein die Gründung von 1000 neuen Museen. Die Mona Lisa wird demnächst am Persischen Golf zu besichtigen sein. Bollywood, die indische Alternative zu Hollywood, eroberte in den letzten Monaten Europa.

Die Künstler der Ausstellung Reimagining A sia setzen sich mit diesen Umbruchprozessen auseinander. In Peking hält das Alte den Modernisierungsschüben einer geradezu explodierenden Stadt nicht mehr stand. Ganze Stadtteile wurden in den letzten Jahren von Baggern niedergerissen. Dieses Schicksal drohte 2002 auch dem Haus der Mutter Song D ongs. D iese hatte gerade ihren Mann verloren. Samt dem Haus wären auch alle $\mathrm{G}$ egenstände verschwunden, die sie seit den fünfziger Jahren aufbewahrt hat. Mit diesen Objekten verband die Mutter aber eine Vielzahl von $\mathrm{G}$ eschichten. In sie war buchstäblich ihr Leben eingeschrieben. So zeigte sie mir aus hunderten von $\mathrm{G}$ egenständen stolz eine Reisschale, die sie genau auf das Jahr 1957 zurückdatieren konnte. Es war das Jahr, als ihr Vater, von den Kommunisten verfolgt, im G efängnis saß. Ihre Mutter schenkte ihr die Schale, weil sie im darauf folgenden Jahr ihr Universitätsstudium beginnen sollte. D ie grünen Schalen aus Blech galten zu dem Zeitpunkt als besonders modern und waren für die jungen Leute deshalb viel begehrenswerter als die klassischen Keramikschalen. Auf der Rückseite sind zwei Zeichen eingeprägt, das eine steht für die private Firma, die diese $\mathrm{G}$ egenstände ursprünglich hergestellt hat, das andere für die $\mathrm{G}$ esellschaft, der danach der Betrieb gehörte.

Die Mutter hatte aufgrund der Räumungsankündigung schon das Haus verlassen und lebte in einer leeren Wohnung. Sie gab die Verbindungen zu Außenwelt mehr und mehr auf. Ihr Blick richtete sich nur noch nach innen und sie verstummte zusehends.

D araufhin bot der besorgte Sohn der Mutter an, das alte Haus Balken für Balken abzubauen und mit allen aufbewahrten Objekten im Museum zu zeigen. Die Mutter lehnte zunächst ab, schämte sich vieler alter Sachen, stimmte aber schließlich zu. D ie gemeinsame Arbeit am Haus und den G egenständen brachte der Mutter die Sprache zurück. Indem der private Raum mit seinen $G$ egenständen der Öf- 
fentlichkeit zugänglich gemacht wurde, wurde aus der Erinnerungsarbeit Song D ongs und seiner Mutter ein öffentlicher Impuls. D as erhaltene Haus ist das Zeichen eines leisen Widerstandes gegen das Vergessen, das Zeugnis einer $\mathrm{Ge}$ schichte, verdrängten Leben, die von der gegenwärtigen Entwicklung begraben werden. D as gewählte Verfahren der D okumentation kommentiert nicht die Entwicklung, es führt sie vor Augen.

Dies ist eine Ebene, die Ausstellung zu lesen. In dem Namen „RE ASIA“, ReImagining Asia“ deutet das "Re“ aber auf weitere Lesarten hin. In der westlichen Geschichte des Sehens haben sich seit der Aufklärung die Auffassungen durchgesetzt, die das Sehen als aktive Handlung des Subjekts begreifen. Es ist eine Haltung, bei der sich die Welt nicht offenbart, sondem erschlossen wird. D as Individuum kategorisiert aufgrund seiner Erfahrung, seines Wissens die Welt.

Es gibt aber auch eine andere Sichtweise, auf die Wilhelm Genazino kürzlich in dem Buch „D er gedehnte Blick“ aufmerksam gemacht hat. Bei hinreichend langem Betrachten des $\mathrm{G}$ egenstandes beginnt dieser ein Eigenleben zu führen, über $\mathrm{G}$ enazino hinausgehend könnte man sagen, der Gegenstand sieht auf den Betrachter zurück, die Subjekt-O bjekt-Beziehung wird umgedreht, die Kategorien des schnellen Hinsehens infrage gestellt. D iese Fähigkeit des "gedehnten Blicks", die eigenen Kategorien abzubauen und sich dabei auf den Gegenstand und seine komplexen Eigenschaften einzulassen, spielt eine zentrale Rolle im Zen-Buddhismus. Dieser hat eigene Übungen entwickelt, die es dem Subjekt erlauben, sein Wissen abzulegen und dabei in eine neue Beziehung zur Welt zu treten. Gewisse westliche Künstler hat diese asiatische Tradition immer wieder fasziniert und sie haben sich von ihr beeinflussen lassen. John Cage zum Beispiel, der den Begriff des Musikalischen um Geräusche und Töne unserer Umwelt erweitert hat. Seine Herangehensweise beschreibt er ganz im Sinne des Zen-Buddhismus so:

„Ich halte einfach nur meine O hren offen und meinen $\mathrm{G}$ eist leer, aber wachsam, weiter nichts. (...) Ich versuche, jeden Ton so wahrzunehmen, wie er ist." (Ingo Metzmacher: Keine Angst vor neuen Tönen. Eine Reise in die Welt der Musik, Berlin 32005.)

Mit dieser Erfahrung spielt die Arbeit der koreanischen Künstlerin Sun K. Kwak. Die großen, ausholenden Malbewegungen ihres Fensterbildes im oberen Foyer des Hauses der Kulturen der Welt erinnern beim ersten Hinsehen an traditionelle asiatische Malverfahren mit schwarzer Tinte. Verweilt aber der Blick und gleitet nicht gleich zum nächsten $\mathrm{G}$ egenstand, gibt die Farboberfläche ihre D reidimensionalität zu erkennen, die scheinbar gemalte O berfläche entpuppt sich als schwarzes Klebeband. Asiatische Malverfahren wurden hier erweitert um westliche Materialien. Im Beziehungsspiel greift die Bewegung der Bänder die organischen Formen des $\mathrm{Ge}$ bäudes auf. Von zwei Seiten kommend prallen die Wellenbewegungen im west- 
lichen Teil der Front, am Türeingang zusammen, sie treffen sich in einem Energiezentrum.

D ie Rasterformen der Fenster, die der Glasfläche eine rigide Struktur verleihen, treten zugunsten der Bewegung der Welle zurück. Das Haus, als Vorposten der westlichen Moderne an der G renze zwischen West und O st stehend, gibt an dieser Stelle seinen statischen, ruhenden Charakter auf. Es wird als ein Ort erfahrbar, an dem östliche und westliche Darstellungsverfahren, aber auch Positionen in Wettstreit treten.

D amit wird die zweite Ebene dieser Ausstellung sichtbar. Sun K. Kwak präsentiert uns in ihrer Arbeit nicht asiatische Kunst. Sie setzt sich in ihrer Sprache mit dem konkreten Ort des Hauses der Kulturen der Welt auseinander. RE ASIA wird dabei als ein Projekt erkennbar, das uns nicht nur Asien näher bringt. Nein, die Arbeiten blicken beim verweilenden Hinschauen auf uns zurück, beziehen uns mit ein.

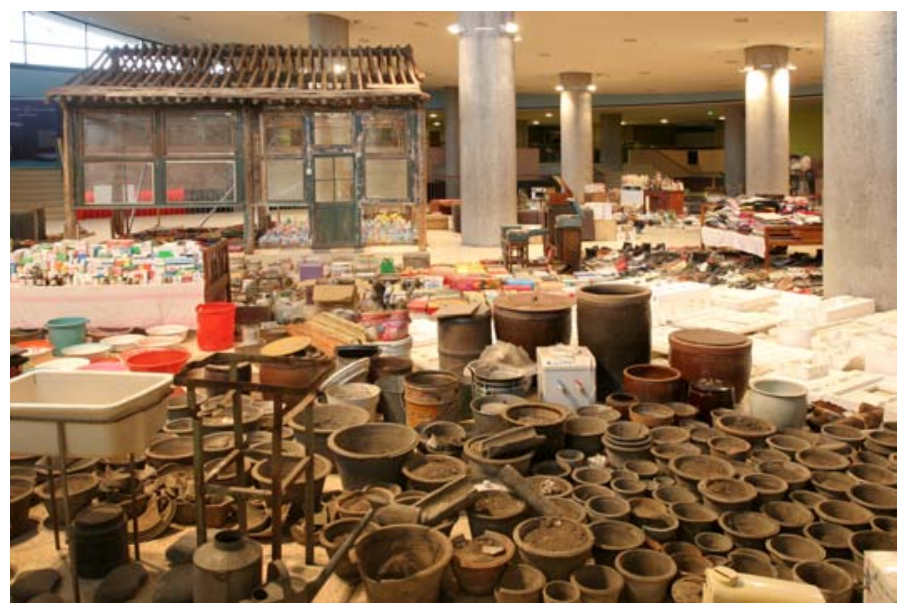

Abb. 1: Dong Song, Waste not (Fotograph: Jens Liebchen)

Kehren wir mit dieser Erfahrung zurück in das Foyer des Gebäudes, dann lassen sich die beiden Wellen K waks direkt übersetzen in die Arbeit D ong Songs. Da ist auf der einen Seite das repräsentative Foyer, das Energiezentrum des Gebäudes, das für den Topos der Offenheit und Strahlkraft westlicher Moderne steht. Unter der Kraft dieses Raumes mit seiner geschwungenen D ecke, seinen massiven Betonpfeilem scheint das aus China kommende traditionelle Holzhaus wirklich zu implodieren. Es entlädt buchstäblich seinen Inhalt, schüttet hunderte von Objekten auf dem Boden der Halle aus. Die schiere Anzahl der Gegenstände, die sich 
auf dem Boden ausbreitet, setzt der Implosion von oben eine eigene Kraft entgegen, Vertikal- und Horizontalbewegung geraten in einen andauernden Wettstreit. D ie über Jahrzehnte gesammelten G egenstände sträuben sich gegen den D ruck des Gebäudes.

Eine vielfältige Dynamik sinnlicher Erfahrung verweist an diesem Ort auf die gesellschaftlichen und politischen Prozesse der letzten Jahrzehnte.

D ong Songs Mutter begann in den fünfziger Jahren des letzten Jahrhunderts mit dem Aufbewahren ihrer Gegenstände. Viele Objekte stammen aus der Zeit einer Moderne, die Mao Tse Tung China vorgeschrieben hatte. Es war die Entwicklung einer Moderne, an der sich auch Architekten und Ingenieure aus Ostdeutschland beteiligten.

Gleichzeitig stritt Berlin, Ost und West, um die „richtige“ Moderne. Und hier spielte die damalige Kongresshalle als G eschenk der Amerikaner an die Stadt eine zentrale Rolle. Sie stand nur einige Meter von der Grenze entfernt in einem zerbombten Niemandsland geradezu als Vorbote westlichen Denkens. Nach 1989 rückte sie in das Zentrum einer Stadt, auf deren östlicher Seite die Gegenstände und Zeichen der vormaligen sozialistischen Moderne einem zunehmend globalen Zwang weichen mussten. Welcher Erfahrungs- und Erinnerungsverlust für einzelne Menschen damit verbunden ist, führt die Arbeit Song D ongs im Foyer des Gebäudes vor Augen. Re-Asia, die Kunst aus Asien blickt auf uns, führt uns unsere eigene Vergangenheit und $\mathrm{G}$ egenwart vor Augen.

Der Titel „Re-imagining Asia“ macht deutlich, dass es noch eine dritte Ebene in dieser Ausstellung gibt. Es geht nicht darum zu definieren, was Asien ist. Die Objekte der Ausstellung beanspruchen in diesem Sinne nicht, Asien zu repräsentieren. Sie beziehen sich auf unsere Vorstellungen, unsere Bildwelten von Asien, locken den Betrachter über diese vereinfachenden Bilder in die Arbeit, um dann ihr Spiel mit verschiedenen Bedeutungsebenen zu beginnen. So stellt Michael Joo eine Buddha-Skulptur ins Zentrum seiner Arbeit und evoziert damit das Bild einer großen asiatischen Tradition. Erste Irritationen treten beim westlichen Betrachter auf, wenn ihm erzählt wird, dass diese Skulptur aus Nord-Pakistan kommt, einem ehemaligen Zentrum des Buddhismus. In den kulturellen Landkarten des Westens scheint diese Zuschreibung nicht zu passen. Da ist Pakistan eindeutig über den Islam konnotiert. $\mathrm{D}$ ann aber wird darüber informiert, dass die $\mathrm{G}$ andhara-Kultur des Industals (2.-6. Jahrhundert nach Christus) sehr stark von griechisch-römischer Kultur geprägt war, es sich also nicht um eine originale Buddha-D arstellung handelt, sondern um eine, die vom griechisch-römischen Schönheitsideal mitgeprägt ist.

Noch nicht genug des Spiels mit den Bedeutungsebenen. Eigentlich handelt es sich nämlich auch nicht um das O riginal der Buddha-Figur, die diese Skulptur zu sein 
vorgibt, sondem nur um eine Replika. Wo findet sich also dieses Original? Die O riginalbuddha-Statue ist längst in D eutschland angekommen. D as ist der Witz. Sie befindet sich im Museum für Asiatische Kunst in Dahlem.

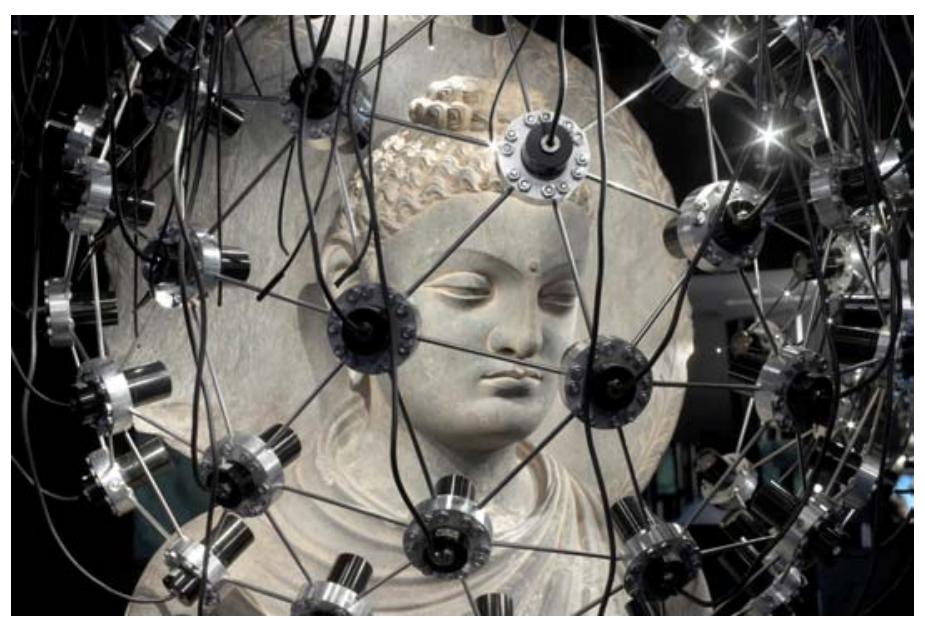

Abb. 2: Michael Joo, Space-Baby (Fotograph: Jens Liebchen)

Der Buddha Michael Joos verkörpert nicht nur verschiedene Zeitebenen, auch räumlich ist er nur mittelbar zugänglich. Er ist nämlich zunächst umgeben von Spiegelwänden, die ihn dem Auge des sich nähernden Zuschauers verbergen. Hat der Zuschauer den Innenbereich der Spiegelwände betreten, erkennt er, dass der Buddha-Kopf von einer Haube, bestehend aus einer Vielzahl von Kameras weitgehend abgeschirmt ist. Diese Kameras übertragen das Bild Buddhas auf eine Reihe von Bildschirmen. Joos Buddha ist nicht mehr direkt, sondern nur noch über Medien vermittelt erfahrbar. Die Kameras erinnern obendrein an Überwachungssysteme, die notwendig werden, wenn Kunst so teuer wird, dass sie der unmittelbaren Erfahrung durch die Öffentlichkeit entzogen werden muss. In diesem Sinne reflektiert die Arbeit auch unseren heutigen Umgang mit Kunst.

Was passiert hier? In dem Projekt RE A SIA wird nicht Kunst aus A sien ausgestellt an einem kontextfreien Ort, den der klassische „White Cube" vorgibt zu sein. Die G egenstände entwickeln spielerisch ein Bedeutungsgeflecht in Auseinandersetzung mit dem konkreten Haus, in dem sie präsentiert werden, und der Vorstellungswelt seiner Besucher. Umgekehrt beansprucht aber auch das Haus nicht im Sinne des klassischen Museums die Definitionsmacht, die bestimmt, wie die Welt zu sehen ist, in unserem Falle was Kunst aus Asien ist. Es ist vielmehr ein Ort mit einer eigenen spezifischen Geschichte. Die Auseinandersetzung mit der „anderen“ Welt führt dabei zur Auseinandersetzung mit der eigenen Position. Dies gilt sowohl für 
das Verständnis unserer eigenen Welt wie der Wahrnehmungsweise der anderen. Indem die eigene Position in diesem lebendigen $G$ espräch als eine unter anderen markiert wird, durch die Referenz auf den eigenen gesellschaftlichen Kontext wird die Allwissenheit des Universalisten unterlaufen. Indem die eigene Position sich durch das G egenüber thematisiert und befragen lässt, also selbst zur Disposition steht, entgehen wir der Falle des Exotismus, die den Anderen nur als Objekt eigener Projektionen kennt.

Im konkreten Austausch dienen die vorgegebenen geographischen Kategorien, Europa - Asien, immer wieder als aufeinander bezogene Welten. Sie werden aber auch selbst befragt. Eine solche zeitgenössische Auseinandersetzung mit anderen Kulturen und G esellschaften führt vor Augen, dass Kulturprozesse ein Geben und Nehmen, eine Herausforderung sind. Ihnen wohnt eine Offenheit und Mehrdeutigkeit inne, die in der historischen Rekonstruktion des eigenen Selbstverständnisses oft bewusst oder unbewusst ausgeblendet wird.

Unsere europäische G eschichte im Verhältnis zur Welt neu zu schreiben bedeutet heute deshalb insbesondere auch die Wechselbeziehungen Europas zur Welt genauer in den Blick zu nehmen.

Ich möchte dies an dem Projekt „In der Wüste der Moderne“ veranschaulichen. D as Haus der Kulturen der Welt bereitet es seit einem Jahr mit einem Forschungsteam unter der Leitung von Marion von Osten, Serhat Karakayali und Tom Avermate vor. Es arbeiten dabei Künstler, Architekten, Soziologen und Stadtplaner zusammen. Im Zentrum des Projekts stehen die kolonialen und postkolonialen Beziehungen zwischen Frankreich und Nordafrika, speziell Marokkos. Es geht um die Frage, wie sich in diesem Kontext das Projekt einer Architekturmoderne entfaltet hat. Ziel ist es, anhand eines bewusst eng definierten Gegenstandsbereichs das Wechselspiel zwischen europäischer und nordafrikanischer Seite bei der Entwicklung eines zentralen Aspekts der Moderne zu analysieren. D abei wird offenbar, dass das kolonisierte Afrika ein zentrales Labor der westlichen Moderne ist. Für französische und in ihrem G efolge auch andere europäische Stadtplaner erscheint der kolonisierte Raum zunächst als weiße, nicht definierte Fläche, wo sich Bauprojekte der Moderne in ungebundener Weise realisieren lassen als in den nach ihrer Auffassung historisch gewachsenen Städten Europas. Casablanca wird geradezu zum Prototyp einer solchen Stadt. Hier entsteht weltweit das erste Haus mit einer eigenen Tiefgarage. Hier werden vor allem in den fünfziger Jahren von dem Architekturbüro Atbat-Afrique (Atelier des Bâtisseurs) in Zusammenarbeit mit Ethnologen und Soziologen Lösungen für großangelegte, moderne Siedlungskomplexe entwickelt. Die neuen urbanen Konzepte erscheinen notwendig aufgrund einer rapide steigenden Bevölkerungszahl und der Migration in die Städte. Die Bidonvilles, von der Landbevölkerung improvisierte Hüttenansiedlungen, werden zum Studienobjekt europäischer Architekten, weil in ihnen traditionelle Siedlungsformen in einen urbanen Kontext übersetzt werden. Aus der Analyse der 
Bidonvilles entwickelten die Architekten von Atbat-Afrique Georges Candilis und Shadrack Woods den für das moderne Bauen so zentralen Begriff des Habitats weiter. Im Konzept des Habitats werden offene und verbindende Räume bei der Entwicklung von Wohnkonzepten mit einbezogen, so dass ein komplexes $\mathrm{Zu}-$ sammenspiel von Innen- und Außenraum entsteht, in dem sich soziale Beziehungen der Bewohner entfalten können. Gleichzeitig entstanden Siedlungskonzepte, die einer mobilen in transitorischen Räumen lebenden Gesellschaft gerecht wurden. D ie Architektur sollte nicht mehr den Zeitläufen standhalten, sondern eine G rundstruktur anbieten, die sich die Bewohner immer von Neuem aneignen konnten.

Die in Nordafrika entwickelten Konzepte wurden auf großen internationalen Kongressen, den Congrès Internationaux d'Architecture Moderne, kurz CIAM, einer internationalen Fachöffentlichkeit vorgestellt und erlangten dadurch Modellcharakter für das Bauen in den fünfziger und sechziger Jahren.

D a französische Städte aufgrund der Landflucht auch nach Lösungen für eine rapide wachsende Stadtbevölkerung suchten, konnten die Konzepte aus Marokko in das Mutterland re-importiert werden. Candilis, Woods und ihr Kollege Josic bauten in den fünfziger und sechziger Jahren mehr als 10.000 Sozialwohnungen, vor allem in Paris, Marseilles und auf Martinique.

Es sind vor allem diese Siedlungen, in die in den letzten Jahrzehnten Migranten aus Nordafrika einzogen. Und in deren Protest wird der von Anfang an bestehende Zusammenhang zwischen Modeme und Kolonialismus zum ersten Male artikuliert.

Es war nämlich der Kolonialismus, der die ganze gerade beschriebene Entwicklung der Moderne in Nordafrika ermöglichte und beförderte, ausgehend von der Bereitstellung der scheinbaren Laborbedingungen bis hin zum Interesse der Kolonialmacht, die Migranten in Vorstädten sesshaft zu machen, um sie ordnungspolitisch kontrollieren zu können. Die Befreiungskämpfe, die zurzeit der Architekturexperimente stattfanden, wurden in den "gesäuberten“ (cleanen) Fotos der Architekturmoderne ausgeblendet. Wie die Kolonisierten ja auch nicht als eigene Subjekte auftreten, sondern nur als Objekte urbaner und ethnologischer Studien, obwohl gerade sie es waren, die im Zwischenraum zwischen Land und Stadt in ihrer Praxis die neuen Urbanisierungsstrategien entwickelten. Indem die ehemals Kolonisierten nun in den Vorstädten Frankreichs deutlich machen, dass das Kolonialprojekt längst in die Metropolen Europas zurückgekommen ist, wird nicht nur das Verhältnis Europas zum nichteuropäischen Raum thematisiert, sondern das Selbstverständnis Europas und seiner scheinbar eigenen Moderne.

D as heißt aber, die heutige Beschäftigung mit der Welt führt dazu, dass wir unsere G eschichte auch neu schreiben müssen. Bezogen auf die Repräsentation im Museum muss dies neue Repräsentationsweisen zur Folge haben, die nicht unsere eigene G eschichte als losgelöst von der $\mathrm{G}$ eschichte der Anderen darstellen. 
Wenn die Positionen von Nichteuropäern aber als gleichberechtigt anerkannt werden, hat das noch eine weitere Konsequenz, die sich an einem Beispiel der letzten Biennale von Venedig illustrieren lässt.

Beim Betreten des italienischen Pavillons in den Giardinis begegnete man Malereien, die der westliche Besucher zunächst der Epoche der Abstraktion zuordnen würde. Bei genauerem Hinsehen fällt dem Betrachter dann die sehr eigene Erdfarbigkeit der Bilder auf und wie das scheinbar konstruktivistische Verfahren aus dem Bild ausbricht und auf die Wand ausgreift. Irritiert durch diese Erfahrung erhält der Besucher genauere Informationen durch den Katalog. D ort erläutert der Kurator Robert Storr den Kontext der Arbeit O dili Donald Oditas, der in Enugu in Kenia geboren wurde und heute in New York lebt. Zunächst verweist Storr darauf, dass in der westlichen Kunstgeschichte die Abstraktion eine Reaktion auf repräsentationale Bildverfahren war. Wurde in diesen eine äußere Wirklichkeit abgebildet, ging es in der abstrakten Malerei darum, die Eigenschaft, Farbe, Form, Materialität des Bildes selbst zu thematisieren. Dieser historische Zusammenhang liegt aber in vielen $\mathrm{G}$ esellschaften in dieser Form überhaupt nicht vor, insbesondere etwa in einigen orthodox-islamischen oder jüdischen Gesellschaften, die einem AbbildVerbot unterliegen. Im Subsahara-Kontext wiederum sind für unser westliches Verständnis abstrakte Bilder in der Regel aus Bildverfahren hervorgegangen, die Beziehungen zwischen Mensch und Natur, bzw. auch spirituelle Kräfte kodifizieren, also in gar keiner Weise auf abstrakte Bildstrategien zurückgehen. D amit stellt Storr die Arbeit von O dita in den Kontext einer eigenen Bildkultur.

Wenn sich aber Bildkulturen in ganz unterschiedlichen historischen Rahmenbedingungen entfaltet haben, dann gibt es nicht nur eine $\mathrm{G}$ eschichte zu erzählen, sondern viele verschiedene $G$ eschichten. Gleiche Überlegungen ließen sich auch anstellen in Bezug auf das Fehlen einer Zentralperspektive in asiatischen Traditionen. Dieser Eigenart entspricht eine ganz andere Wahrnehmungsweise durch den Betrachter.

Wie die eigene $\mathrm{G}$ eschichte neu wahrgenommen werden muss, nämlich mit eingehendem Bezug zum Rest der Welt, so besteht auch die Herausforderung einer heutigen Kunst- und Kulturinstitution, die die Geschichte des Museums weiterentwickelt, darin, den Bezugsrahmen der eigenen Repräsentation mitzudenken und sich für die Auseinandersetzung mit anderen Bedeutungssystemen zu öffnen. D as heißt aber anzuerkennen, dass es nicht nur eine, sondern viele Geschichten zu schreiben gibt. Ich habe dies hier an einem ästhetischen Phänomen verdeutlicht, es ließe sich aber auch auf regionale Beispiele übertragen. So beschreibt Amitav Ghosh in "In einem alten Land" die Handelsbeziehungen auf dem Indischen O zean zwischen Ägypten, Afrika und Indien als eine Welt, die zunächst völlig unabhängig von den Europäern existierte. Im 19./ 20. Jahrhundert wurden diese Beziehungen wieder intensiviert aufgrund der indischen Kolonien an der O stküste Afri- 
kas, die dort unter anderem zu einem frühen Boom von Bollywood, des Kinos aus Bombay führten.

In der neuen Auseinandersetzung D eutschlands/ Europas mit der Welt geht es also darum,

1. eine teilweise gemeinsame $\mathrm{G}$ eschichte neu zu schreiben,

2. anzuerkennen, dass es nicht nur eine, sondern viele $G$ eschichten gibt, bzw. nicht nur einen Bezugsrahmen, sondern mehrere,

3. in der Auseinandersetzung mit der Welt sich selbst neu zu bestimmen und entsprechend auch die Rolle historisch gewachsener Institutionen wie die des Museums neu zu definieren,

4. sich der Tatsache bewusst zu sein, dass aufgrund von Migration, wie das Marokko-Besispiel zeigt, die „Anderen“, deren G eschichte wir mitschreiben, schon längst unter uns leben.

D azu ist erforderlich:

1. Die Wissensproduktion mit der Inszenierung des Wissens auf neue Art zu verbinden. Dabei liegen auch in der Inszenierung Aspekte der Wissensproduktion. D erjenige, der In-Szene-setzt generiert dabei eigenes Wissen.

2. Forscherteams zusammenzustellen aus verschiedenen Wissenstraditionen: Soziologen, Ethnologen, zeitgenössische Kuratoren und Kunsthistoriker, die aus einer zeitgenössischen Perspektive G eschichte erarbeiten und inszenieren.

3. Zusammenarbeit mit internationalen Kuratoren und Experten, um die Perspektive der Anderen mit einzubeziehen, um anderen G eschichten einen eigenen Raum zu geben.

4. Da sowohl die Forschung wie die Inszenierung länger dauernde Prozesse sind, ist das Haus der Kulturen der Welt nicht nur ein G ebäude sondern ein geistiges Projekt für die nächsten Jahrzehnte. 


\section{Autorinnen und Autoren}

Casper-Hehne, Hiltraud, Prof. Dr. Interkulturelle Germanistik, Universität Göttingen

Grünschloß, Andreas, Prof. Dr. Religionswissenschaft, Universität Göttingen

Hess-Lüttich, Ernest W.B., Prof. Dr. Institut für Germanistik, Universität Bern

Hsia, Adrian, Prof. Dr. Germanistik, McGill University, Montreal

Karakaşoğlu, Yasemin, Prof. Dr. Interkulturelle Bildung, Universität Bremen

Limbach, Jutta, Prof. Dr. Verfassungsrichterin, Präsidentin des Goethe-Instituts a. D., München

Richter, Jochen EU-Kommission für Mehrsprachigkeit, Brüssel

Scherer, Bernd, Dr. Intendant Haus der Kulturen der Welt, Berlin

Schlögel, Karl, Prof. Dr. Osteuropäische Geschichte, Universität Viadrina, Frankfurt/Oder

Schweiger, Irmy, Dr. Deutsch-Chinesisches Institut für Interkulturelle Germanistik und Kulturvergleich, Universität Göttingen

Vertovec, Steven, Prof. Dr. Max-Planck-Institut zur Erforschung multireligiöser und multiethnischer Gesellschaften, Göttingen

Wendehorst, Christiane, Prof. Dr. Rechtswissenschaft, Universität Wien 
W eltweite Globalisierungsprozesse und die Zunahme an gesellschaftlicher, religiöser, und weltwirtschaftlicher Komplexität haben die Begriffe „Interkulturalität“ und „Dialog“ nicht nur in der politischen Praxis, sondern auch in zahlreichen Wissenschaftsdisziplinen vehement an Bedeutung gewinnen lassen. Gleichwohl ist unübersehbar, dass „Interkulturalität“ bislang nur vage theoretisch fundiert ist, jedoch als Bezugspunkt für einen sich neu entwickelnden Verstehens- und Interaktionszusammenhang immer wieder in Erscheinung tritt. Genau in diese "Leerstelle" sucht die hier dokumentierte Vorlesungsreihe zu treten, um sich aus der Perspektive unterschiedlicher, in vielerlei Hinsicht am akademischen Diskurs aktiv beteiligter Fächer mit einem „Interkulturellen Dialog“ auseinanderzusetzen. In ihrer Zusammenschau plädieren die hier versammelten Perspektiven für ein vernetztes Verstehen, das Grenzen zwischen Disziplinen, Kulturen, Religionen sowie Nationen hinter sich lässt. In den Beiträgen zeichnet sich eine Prozesshaftigkeit ab, die ausgehend von einer Hermeneutik des Fremden auf die Überwindung von Fremdheit zielt, um sich dann auf die Anerkennung der Differenz und Vielfalt von Kulturen hin zu bewegen. 